Gabriele Pisarz-Ramirez /

Hannes Warnecke-Berger (eds.)

\title{
Processes of Spatialization in the Americas
}

Configurations and Narratives

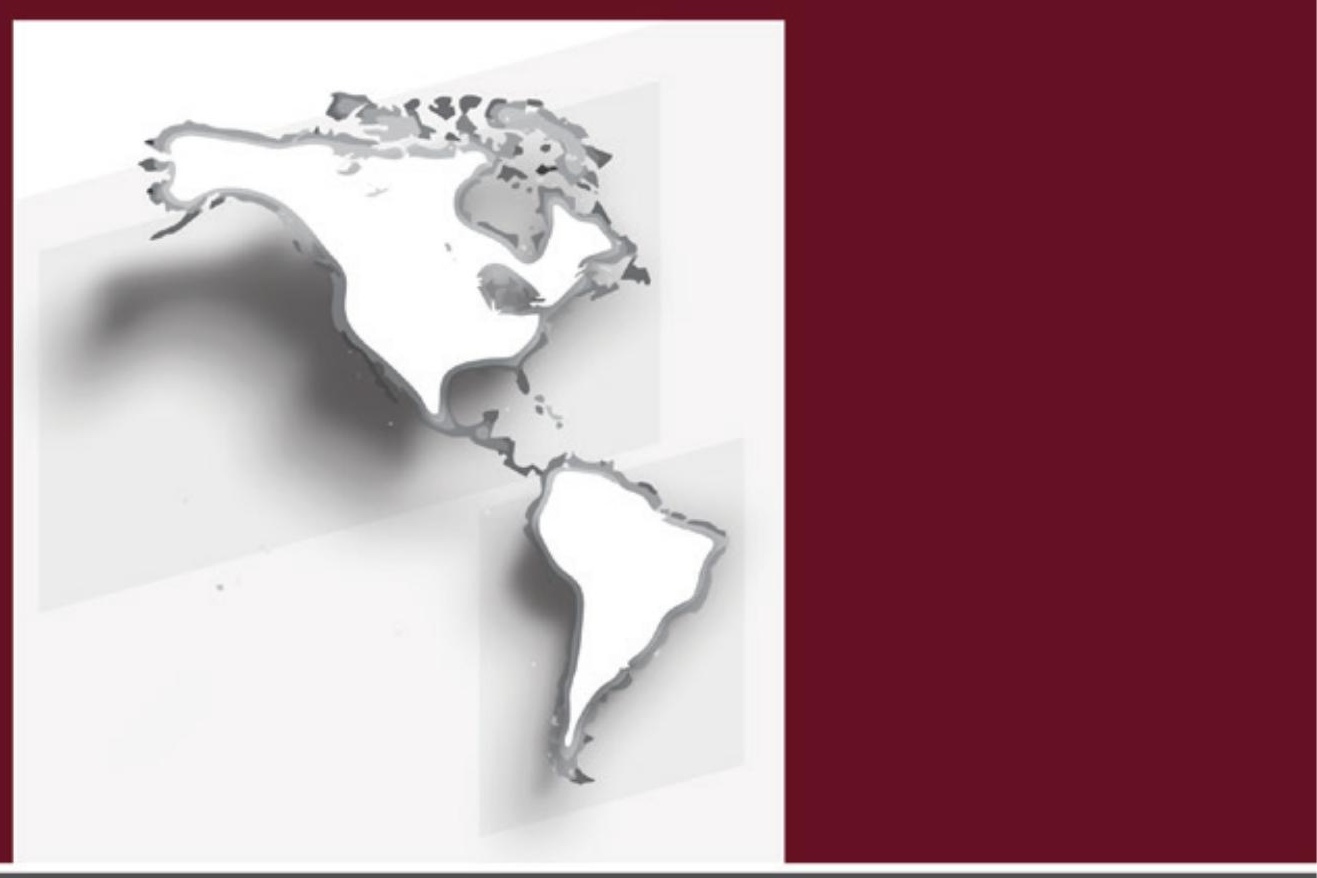


Gabriele Pisarz-Ramirez /

Hannes Warnecke-Berger (eds.)

\section{Processes of Spatialization in the Americas}

Where do the Americas begin, and where do they end? What is the relationship between the spatial constructions of "area" and "continent"? How were the Americas imagined by different actors in different historical periods, and how were these imaginations - as continent, nation, region - guided by changing agendas and priorities? This interdisciplinary volume addresses competing and conflicting configurations and narratives of spatialization in the context of globalization processes from the 19th century to the present.

\section{The Editors}

Gabriele Pisarz-Ramirez is Professor of American Studies and Minority Studies at Leipzig University and Principal Investigator in the Collaborative Research Center "Spatialization Processes under the Global Condition".

Hannes Warnecke-Berger is a Political Scientist and currently Senior Researcher at the Department of International and Intersocietal Relations at the University of Kassel. 
Processes of Spatialization in the Americas 


\section{INTERAMERICANA \\ INTER-AMERICAN LITERARY HISTORY AND CULTURE HISTORIA LITERARIA INTERAMERICANA Y SUS CONTEXTOS CULTURALES \\ HISTOIRE LITTÉRAIRE ET CULTURE INTERAMÉRICAINES}

\section{Editors:}

Marietta Messmer (University of Groningen / editor-in-chief), Barbara Buchenau (University of Duisburg-Essen), Michael Drexler (Bucknell University),

Graciela Martínez-Zalce Sánchez (Univ. Nacional Autónoma de México) and Gabriele Pisarz-Ramirez (University of Leipzig)

Reviewers and Advisors:

Ralph Bauer (University of Maryland), Robert Dion (University of Québec at Montreal), Yolanda Minerva Campos García (Universidad de Guadalajara), Manfred Engelbert (University of California at Los Angeles), Earl Fitz (Vanderbilt University at Nashville), Carole Gerson (Simon Fraser University at Burnaby/B.C.), Daniel Göske (University of Kassel), Markus Heide (Uppsala University), Djelal Kadir (Pennsylvania

State University), Efraín Kristal (University of California at Los Angeles), Kurt Mueller-Vollmer (Stanford University), Carla Mulford (Pennsylvania State University), Denis St. Jacques (Laval University at Québec) and Jeanette den Toonder (University of Groningen)

\section{VOLUME 13}

Notes on the quality assurance and peer review of this publication:

Prior to publication, the quality of the works published in this series is reviewed by external referees appointed by the editorship. 
Gabriele Pisarz-Ramirez and Hannes Warnecke-Berger (eds.)

\section{Processes of Spatialization in the Americas}

Configurations and Narratives

\section{里


Bibliographic Information published by the Deutsche Nationalbibliothek The Deutsche Nationalbibliothek lists this publication in the Deutsche Nationalbibliografie; detailed bibliographicdata is available in the internet at http://dnb.d-nb.de.

\section{Library of Congress Cataloging-in-Publication Data}

A CIP catalog record for this book has been applied for at the Library of Congress.

Gratefully acknowledging financial support by DFG

- Deutsche Forschungsgemeinschaft.

Cover Design: (c) Olaf Gloeckler, Atelier Platen, Friedberg

Cover Image: (c) Hannes Warnecke-Berger

ISSN 1618-419X
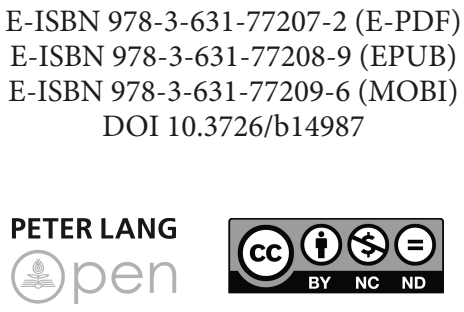

Open Access: This work is licensed under a Creative Commons Attribution Non Commercial No Derivatives 4.0 unported license. To view a copy of this license, visit https://creativecommons.org/licenses/by-nc-nd/4.0/

(C) Gabriele Pisarz-Ramirez and Hannes

Warnecke-Berger (eds.), 2018

Peter Lang - Berlin · Bern · Bruxelles · New York ·

Oxford $\cdot$ Warszawa $\cdot$ Wien 


\section{Contents}

Notes on Contributors

Hannes Warnecke-Berger and Gabriele Pisarz-Ramirez

Spatialization Processes in the Americas: Configurations and Narratives

Producing Space: The Americas between Homogeneity and Heterogeneity

Peter Birle

Regionalism and Regionalization in Latin America: Drivers

and Obstacles

Gesa Mackenthun

Storied Landscapes: Colonial and Transcultural Inscriptions of the Land ....

Steffen Wöll

Spatiality and Psyche: Surviving the Yukon in Jack London's "Love of

Life" and "To Build a Fire"

Thomas Plötze

Regional Homogeneity by Force or by Conviction? Central American

Regionalism in a Long-Term Perspective

Configuring Space: Borders, Frontiers, and the Dialectics of Inclusion and Exclusion

Josef Raab

Contestation, Hybridization, Criminalization: US-Mexican Borderland

Vistas

Gabriele Pisarz-Ramirez

Florida as a Hemispheric Region

Megan Maruschke

Bordering through the Lens of Slavery and Abolition in the United States 
Antje Dietze

Americanization of Show Business? Shifting Territories of Theatrical

Entertainment in North America at the Turn of the 20th Century

Transgressing Space: Globalization, Mobility, and Bordercrossings

Hannes Warnecke-Berger

Salvadoran Transnational Transgressions: Remittances, Rents, and the Struggle over Economic Space

Sebastian Huhn and Christoph A. Rass

The Post-World War II Resettlement of European Refugees in Venezuela: A Twofold Translation of Migration 243

List of Figures and Tables 269 


\section{Notes on Contributors}

Peter Birle, political scientist, heads the research department of the IberoAmerikanisches Institut in Berlin and teaches at the FU Berlin. His research interests are Latin American foreign policies in comparative perspective, Regional Cooperation and Integration in Latin America, and knowledge production in and about Latin America.

Antje Dietze is senior researcher at the Collaborative Research Centre "Processes of Spatialization under the Global Condition" and member of the Institute of Cultural Studies at Leipzig University. Her current research focuses on the history of entertainment industries in a transatlantic perspective.

Sebastian Huhn is senior researcher at the Chair for Modern History and Historical Migration Research at the University of Osnabrück. He is a member of the Institute for Migration Research and Intercultural Studies at the University of Osnabrück.

Gesa Mackenthun is Professor of American Studies at Rostock University. Her current research deals with nineteenth-century imperial travel and archaeology and the scientific constructions of American antiquity.

Megan Maruschke is senior researcher at the Collaborative Research Centre "Processes of Spatialization under the Global Condition" and member of the Global and European Studies Institute at Leipzig University. Her research focuses on special economic zones during the second half of the 20th century and on the spatial transformation of the Americas at the time of decolonization and the French revolution.

Gabriele Pisarz-Ramirez is Professor of American Studies and Minority Studies at Leipzig University. Her areas of research include Mexican American literature and culture, early American hemispheric studies, and the study of the US South in a circum-Caribbean context. Currently she is working within the Collaborative Research Centre "Processes of Spatialization under the Global Condition" at Leipzig University on a project focusing on "Spatial Fictions: (Re) Imaginations of Nationality in the Southern and Western Peripheries of 19th Century America". 
Thomas Plötze, political scientist, is junior researcher at the Chair of International Relations, Leipzig University. His research touches on the nexus of securitization and regional security cooperation since 1980s in Central America.

Josef Raab is Professor of North American Literature and Culture at the University of Duisburg-Essen. He served as Founding President of the International Association of Inter-American Studies from 2009 through 2018. Most recently he co-edited Spaces-Communities-Discourses: Charting Identity and Belonging in the Americas (2016).

Christoph A. Rass is Professor for Modern History and Historical Migration Research and member of the Institute for Migration Research and Intercultural Studies at the University of Osnabrück.

Hannes Warnecke-Berger is senior researcher at University of Kassel. His research interests are on political economy, development, violence, and migration. His empirical research focuses on Central America, West Africa and Southeast Asia.

Steffen Wöll is research fellow at the Collaborative Research Centre "Processes of Spatialization under the Global Condition" at Leipzig University. He is a $\mathrm{PhD}$ candidate working on "Globe, Region, and Periphery: The Spatialization of the American West in Nineteenth-Century US Literature." 


\title{
Spatialization Processes in the Americas: Configurations and Narratives
}

\author{
Now, these parts of the earth have been more extensively \\ explored and a fourth part has been discovered by \\ Amerigo Vespucci (as will be set forth in what follows). \\ Inasmuch as both Europe and Asia received their names \\ from women, I see no reason why anyone should justly \\ object to calling this part Amerige, i.e., the land of \\ Amerigo, or America, after Amerigo, its discoverer, a man \\ of great ability. (Waldseemüller 70)
}

At the beginning of the 16th century, the cosmographer Martin Waldseemüller and his colleague Matthias Ringmann both worked on their Cosmographiae Introductio. While they had never been to America, they had read extensively on the "discovery" of the New World, including Vespucci's Mundus Novus, which was a bestseller at that time. By 1503, Vespucci had published a description of his voyage of 1501, and by 1529, it had already been distributed in 60 editions and translated into almost every European language (Hirsch 540). Based on Vespucci's and other travel reports, Waldseemüller created his popular world map where for the first time in history the newly discovered territories were called America. By putting "America on a map" (Schwartz; see Dickson for a critical reflection), Waldseemüller invented America and gave the New World its name. America's 'newness' was as much a European invention, of course, as the idea that it was 'discovered' (O'Gorman). The discourse of its discovery and newness nevertheless became one of the key foundational narratives of the Americas. As Gregory Rabasa has pointed out, the term 'New World' marked not only an imaginary geographic space but also "the constitution of the modern conception of the world that results from the exploration of the globe," that is the exploration of new fields of inquiry (Rabasa 3 ).

However, from the very beginning, the Americas were contested. The first reason for this was that the name that Waldseemüller put on the map never gained consensus. In Spain, for example, the name 'America' was refused until the 18th century (Randles 53). Instead, the terms Indias Occidentales or simply Nueva España enjoyed much more popularity. The map makes another point 
clear. The naming and framing of the Americas was inevitably disconnected from the practices and experiences of the people living in or colonizing this part of the world. The name 'America' initially appeared on a map that Waldseemüller produced in Freiburg. It was not the invention of Vespucci or Columbus, and the reason why 'America' soon after Cosmographiae Introductio enjoyed such popularity, did not necessarily relate to the discovery itself.

A second cause why the Americas were contested was that this new land did not fit into the traditional European reasoning of Christianity. Medieval maps (so-called T-O maps or Beatus maps), such as the famous map published in the 7th century by Isidore of Seville in his Etymologiae that showed the apostolic dissemination of the Faith, depicted Jerusalem at the center of a circle, surrounded by three continents-Europe, Asia, and Africa. When Europe found itself confronted with the Americas, the question arose if all this land was part of the same oikoumene, if each part of this world was really part of the same world (and under the same God). Eventually, this question was resolved by the concept of terra continens and each part of the world progressively became accepted as a "continent" (Randles 53-54). The invention of Americaforged in the process of European colonial history-implied the appropriation and integration of the continent into the Euro-Christian imaginary (Mignolo, The Idea 2-3).

Third, the discovery of the Americas led to a revolutionary shift in cartography (Padrón, The Spacious). Increasingly, the necessities of political and economic relationships with the New World challenged traditional mapmakers to adjust their products to the needs of sailors and captains. Paradoxically, however, Spain was the empire in which maps spread very late most notably in contrast to France and especially in contrast to England (Padrón, "Mapping" 55). As an effect of this cartographic revolution, an abstract and homogenous geometric space was born. This contributed to Newton's path-breaking idea of absolute space, which "in its own nature, without regard to anything external, remains always similar and immovable" (Newton 46). As such "formal and quantitative, it erases distinctions," acknowledged Henri Lefebvre powerfully in his critique of the production of space (Lefebvre 49). At the same time, this emerging cartographic abstract space mirrored new power ambitions of the forming European empires: it created the idea that space was something "over which systematic dominance was possible, and provided a powerful framework for political expansion and control" (Woodward 87). Indeed, the main interest of Europe in the New World was economic in nature. Between 1500 and 1650, Europe imported at least 180 tons of gold and 17,000 tons of silver, which in the last quarter of the 16 th century constituted up to $85 \%$ of the world's silver production (Blaut 189). 
America had a vital impact in Europe, at least for balancing the traditional trade deficits with Asia.

Taking these issues together, the Americas were not only born as a linguistic and cartographic term or semiotic creation, but they were the effect of a dialectic between the practice and the knowledge construction of the colonized, the colonizers, and the imaginaries of European intellectuals. What America and the Americas actually are and for what they were taken are the products of both the social practices in as well as beyond the Americas and of the epistemological assumptions, foundational mythmaking, and narrations on and about the continent and the regions, countries, and people on it. However, this was an essentially unequal process. Colonization, (de)territorialization, destruction, and enculturation, as Padrón rightly affirms, "all of these things probably look the same to the colonized other, regardless of whether or not the colonizer has learned to think about space" (Padrón, "Mapping" 55). The formation of the discourse on the Americas reflects the power structures and geopolitics of knowledge from the perspective of coloniality (Mignolo, The Idea xi). It excludes the histories, experiences, and narratives of Indians and African slaves. As Mignolo observes, "After all, the Americas exist today only as a consequence of European colonial expansion and the narrative of that expansion from the European perspective, the perspective of modernity" (The Idea xi).

What are the Americas then? Whose Americas are we speaking of? Where do the Americas begin and where do they end? How were they constructed by different actors, and what were the priorities and objectives of these different constructions as continent, region, or nation? Which competing and conflicting narratives of spatialization can we observe in the past, which dynamics of exclusion and inclusion are reflected in these narratives, and how do contemporary discourses about the Americas as a construction relate to earlier narratives? These questions can be discussed on various levels, depending on our focus: do we look at the Americas as a particular, homogeneous entity or do we raise further theoretical issues? Such issues would be: how do we define space? How much homogeneity is needed to speak about one particular space (e.g. the Americas) in contrast to other spaces (e.g. Europe or Asia, but likewise Anglophone and Latin America)? How can we investigate this space and what are the appropriate methods? In turn, do we thus construct this supposedly homogenous space through our own focus and through the questions we ask at the beginning of each research? Finally, does the often-proposed way out of this dilemma, namely to look at anti-spaces, heterotopias, the monstrous other, at borders and frontiers, really resolve this problem of supposed homogeneity? What do we gain by looking at the fissures and dividing lines that fracture this 
homogeneity, at the margins and peripheries and interstitial spaces? This volume of essays addresses some of these questions. It has emerged from a workshop that was convened as part of the Collaborative Research Center "Spatialization Processes under the Global Condition" at the University of Leipzig in April 2017. The workshop was designed as a discussion on spatialization processes but also as an invitation to rethink different disciplinary traditions.

\section{Area Studies and the Americas}

The different questions and trajectories of talking, thinking, and theorizing about the Americas do not only reflect ontological differences inherent in the particular space "Americas" but mirror at the same time long-standing disciplinary divides. We took these divides as a starting point and invited scholars from different disciplinary backgrounds to Leipzig to further reflect on and discuss processes of spatialization in the Americas. The empirical background of American studies was traditionally the United States and Canada while Latin America formed a distinct research community, namely Latin American studies. Area studies are confronted with the same question that we post in this book: When is an area an area? What makes the Americas one, two, or numerous different areas? Who defines areas, and what guides such definitions?

Area studies in general and Latin American studies in particular are themselves confronted with a lack of certainty about their adequate research object, be it area in general, the Americas, or North/Latin America in particular. Moreover, area studies have undergone an ontological shift during the last decades. Originally, the motivation of area studies was to gain knowledge of certain areas in the world in an attempt to safeguard European colonial and later US-American national and neo-imperial interests in a global confrontation with communism, and eventually to forward the goals of "modernization and development' as proposed by the Ethnogeographic Commission (Rowe, "Areas" 16). From the perspective of area studies, the United States was not considered an 'area' in the sense other areas such as East Asia, the Middle East or Latin America were, rather it was regarded, along with Canada, as 'an extension of European Civilization' (Rowe, "Areas" 14), following the assumption that knowledge production happened in the centers about those areas under study and their populations that were not seen as part of these centers.

While traditional social science disciplines have remained rather focused on the West, thereby constructing North America as well as Europe as homogenous spaces defined by democracy and market economy and as a normative to the direction in which the "rest" of the world should develop, they left area studies to 
research 'the other' part of the Americas. Consequently, social sciences integrated area studies based on the debates on development and development theory of the 1970s and 1980s (Schäbler 27). By the end of the Cold War, however, development theory lost serious ground. It was accused of rather blurring disciplinary terms and concepts. On the one hand, the distinction between "developed" and "underdeveloped" areas proved to remain rather unclear (Nuscheler). On the other hand, leading authors refused the unifying concept of the 'Third World' and therefore the common research object of the entire sub-discipline. Already back in 1985, Boeckh denied the general explanatory force of dependency approaches, which aimed to explain the phenomena of underdevelopment and dependency in the Third World (Boeckh). His main argument against general theories of development exposed the Third World as much too heterogeneous to fit into a single category. Eventually, with Menzel's call to abandon the category of the Third World the ontological shift was achieved: 'the' Third World as a homogeneous space as well as a particular area would not exist and/or never existed (Menzel). Moreover and as an implication, the existence of particular but homogenous areas, which are to be investigated by development research and which share certain ontological similarities, is more than ever contested.

In American studies, beginning in the 1960s and 1970s, the assumptions of US exceptionalism came under critical scrutiny from within the discipline. The belief in the uniqueness of the United States on the continent, the claim of its superiority to and independence of other countries in the Americas, and the conviction of the absence of imperialism in American history were questioned, starting with the interventions of feminist and ethnic minority scholars who pointed out that large groups of American society as well as its social and ethnic diversity remained invisible and unstudied in the field. Decisive impulses for a methodological revision of the study of the United States came from the 'New Americanists' who investigated the imperial history of the United States and showed that from its early beginnings, like other colonialist nations, the United States were shaped by imperialism (Kaplan and Pease). They emphasized that the consideration of local conditions should be contextualized in a larger understanding of the United States in global comparative contexts. The New Americanists strove for an internationalization of the field, opening up the frame of perception and interpretation for existing but obscured connections, such as Southern California's relation to Asia and Mexico, the Southeast's relation to the 'Black Atlantic', and Miami's relations with Cuba, Haiti, and Latin America (Rowe, "Post-Nationalism" 30), as well as for an awareness that America is, as Brian T. Edwards and Dilip P. Gaonkar put it, a "node in the global circuit" (Edwards and Gaonkar 26). 
Latin American studies in contrast to American studies has always pointed to US imperialist tendencies. This critique of American exceptionalism increased with the rise of dependency theory, the Cuban Revolution, and with the shift in US foreign policy towards reintegrating Latin America into the US-dominated hemisphere with the Alliance for Progress in 1961. Thus, reflecting the dependent development, Latin American studies grew by focusing on the peculiarity of Latin America as a distinct region apart from dominating US America. Moreover, area studies experienced an epistemological shift. Initiated by Said's critique of Orientalism (Said) and the rise of post-colonial (Bhabha, Spivak) and Latin American subaltern studies (Quijano, Dussel), area studies began to focus on the theoretical as well as practical construction of categories such as the 'Third World' or Latin America.

Many of these studies pointed out that these supposedly homogenous spaces do not exist on their own but rather reflect global Western thought and its implicit claim on global domination. The investigation of the history of colonialism and globalization (e.g. Gilroy's The Black Atlantic, Atlantic history, diaspora studies, and the study of transnational migrant communities) revealed the assumption of ontological spatial homogeneity to be a Eurocentric fiction. Likewise, scholars such as Joseph Roach ("Circum-Atlantic performance"), Walter Mignolo ("Border Gnosis" [Mignolo, Local 13]), Gloria Anzaldúa (“Borderlands”), Aníbal Quijano ("coloniality of power"), and others started to rewrite the history of inter-American cultural contacts, employing paradigms that link the Americas in a framework transcending the concepts of "First" and "Third World" and highlighting the power asymmetries characterizing the relations between the different parts of the Americas. In this light, areas are by no means natural phenomena but portray the cartographic fragmentation by Eurocentric requirements, just as Waldseemüller actually did in his Cosmographiae Introductio. Concepts such as unitary nations, societies, or states would not allow for describing particular processes of social change outside Europe and North America.

Finally, these issues culminate in a disputable methodological claim. Following these argumentative lines, areas are either too heterogeneous and similarities between different areas are superficial, or they are themselves the product of discourses and legacies of Western colonialism. Hence, traditional comparative approaches do not make sense. The preferred methodological access to areas and to the Americas as a particular area consequently shifted towards the ideographic reconstruction of single cases and thick descriptions of particular events (Gibson-Graham). In contrast to traditional comparative perspectives, the reciprocal interactions and interferences, transfers, and cultural appropriations enjoy primary attention (Burke; Werner and Zimmermann; Espagne). The field 
of inter-American studies has focused on the study of previously unexplored aspects of the relatedness of the various parts of the Americas, examining the ways in which the different regions have throughout their history been economically, politically, and culturally entangled with each other, be it through the slave trade, be it through the United States' nineteenth-century expansionist ventures in the Caribbean and Central America or its more recent military involvement in various Latin American countries. With this methodological claim, however, an entire epistemological position shifted in favor of post-positivist thinking, and in some regard, abandoned the strict (and perhaps too strict) methodological rigor.

Against this background, the volume combines three different perspectives on space and processes of spatialization in the Americas. A first group of authors reflects on the process of how spaces are produced and how they become visible in the first place. A second group of authors then addresses configurations of space in order to understand how, why, and where spaces are shaped, designed, and which form they take. Finally, a third group of authors discusses the transgression of space(s). These three layers of spatializations will be briefly discussed.

\section{Producing Space: The Americas between Homogeneity and Heterogeneity}

In Waldseemüller's Cosmographiae Introductio the common criterion welding the Americas together was the name of its alleged developer, Amerigo Vespucci, and the simple fact that Waldseemüller perhaps thought that Vespucci discovered a single land mass. Today, this argument is hard to defend. What do Panama, Newfoundland, and Tierra del Fuego have in common? What defines the spatial core of the Americas? Does this space depend on historical (e.g. different colonial powers), economic (e.g. core vs. periphery), geostrategic (e.g. US-American backyard or Latin American autonomy), or religious (e.g. Catholicism vs. Protestantism) factors?

What do economics, politics, culture, languages, literatures, philosophy, religion, and histories tell us about the significance, the depth, and the duration of these spatializations in the Americas as well as about their frontiers and borders? How much similarity of all these different parts should be given or assumed to think of one singular space? How much difference and heterogeneity is still allowed to think of a singular space? How deep are divisions leading to the perception of diverging or even separated spaces?

The Americas are usually perceived as two subcontinents: North America and Latin America. However, this distinction is based on different typologies: while North America is defined geographically, it is the cultural heritage, 
and particularly the languages, that define Latin America. Both the geographical and the cultural perspective on their own do only partially solve the question what the Americas are: North America does not only contain the United States and Canada, but Mexico. Furthermore, Quebec is not part of the Anglophone North. This same problem arises looking at Latin America. Cuba, Haiti, and the Dominican Republic are usually treated as part of Latin America with some reason, but at the same time, geographically, these islands are part of the Caribbean. The distinction between North America and South America, again, ignores the Central American isthmus. Panama and Belize are both deviations of this geographical and culturalist distinction. The Spanish initially colonized Belize. However, the British fought Spain in the Caribbean and integrated today's Belize as British Honduras into their empire.

Taking ancient civilizations as a starting point, the picture becomes even more blurred. In this perspective, the southern parts of Mexico as well as the north of Colombia and Venezuela would be a part of Central America. Ironically, parts of North America as well as of South America then would be located in Central America. Moreover, even South America with its seemingly clear continental borders is far from being homogenous. It includes at least two linguistic, historical, and cultural life-worlds: Brazil as a former Portuguese colony as well as Hispanic Latin America with its Spanish colonial roots (on the history of these disputes, see e.g. Bernecker). Thus, the geographical perspective almost automatically links up with a historic-cultural perspective. More precisely: the question what the Americas "are" does not on its own produce an adequate response.

Scholars have employed the term 'the Western hemisphere' as a frame for comparative critical practice, literary analysis, literary history, and cultural studies related to the Americas. Eugene Bolton's much debated article "The Epic of Greater America” (1933), which was first delivered as a presidential address to the American Historical Association in 1932, summoned historians to think hemispherically; his address investigated the interrelated histories of the Americas, from Canada to Tierra del Fuego, and observed parallel processes occurring throughout the Americas, from colonization to the wars of independence and nation-building. An essay collection edited by Lewis Hanke asked in 1964 Do the Americas Have a Common History?; another collection by Gustavo Pérez Firmat's inquired Do the Americas Have a Common Literature? (1990). Much of the current transnational and hemispheric work in American Studies takes up such research, but at the same time questions certain assumptions of national belonging that inform and influence earlier 'hemispheric' scholarship.

Again, trying to answer the question what connects the Americas much depends on the viewpoint. While the development of the Americas began as 
a cause of disagreement of European great powers, the revolutionary cycle of the long 18th century with the Glorious Revolution, the Haitian Revolution, the French Revolution, the independence of the United States, and finally the independence of Latin America challenged European supremacy. For Latin America, the United States replaced Spain and its Holy Alliance as a dominant force on the continent. The Monroe doctrine quickly resulted in new dependencies as the United States declared Latin America their "backyard." The United States, in contrast, developed into a global superpower, even if it denied being an empire. US imperialism, although widely discussed in Latin American Studies and social sciences, and particularly in political science, remained a blind spot in American Studies until quite recently (Kaplan and Pease). And while in Latin America poverty, marginality, and underdevelopment remained almost entirely untouched over the last 200 years (Pérez Caldentey and Vernengo), the United States as well as Canada are today among the richest societies in the world.

Peter Birle discusses these questions in the light of regional cooperation in Latin America. He shows that regionalization oscillates between political fragmentation and the emerging forms of political integration or between the objective to produce homogeneity and the permanent threat of fragmentation. Covering the longue durée of regionalization, Birle argues that a forming regional space in Latin America closely relates not only to the politics of sovereignty, but necessarily includes the developing strategies prevailing in and throughout the region. Gesa Mackenthun, in her contribution, points out that the Americas have been heterogeneous as a contact zone of many cultures ever since the time before European colonial powers arrived. Exploring "rimlands" in the US Pacific Northwest as multiply inscribed places, she discusses the narrativization of cultural and geological memories in connection with current court cases related to conflicts between indigenous and industrial interests about oil and gas extraction in Cascadia. Her essay that integrates paintings by indigenous artists poses the question "whose land" we are actually talking about. This is the starting point of Steffen Wöll's chapter. He argues that the work of Jack London can be read as a differentiated reflection and sometimes even as a counterpoint to the racialist hierarchies that often dominate the discourse on space and spatialization during much of the nineteenth in Northern US America. He explores psycho-spatial place-making dynamics in London's texts in the context of US imperial politics of white supremacy, showing that imagined spaces all too often resist being fixed as either heterogeneous or homogenous. Finally, Thomas Plötze, drawing on the idea of specific local and time-dependent contexts, argues that the political and geographic space that is today called Central America is by no means a typical or even natural region. Regional spatial homogeneity is the outcome of a historical 
struggle over the proper perception of and the appropriate answer to external political threats. Plötze, thus, shows that external threats lead to political changes within the region-just as the sociology of conflict predicts-which finally result in the construction of a unified internal identity in which regional politics are encouraged and pursued.

\section{Configuring Space: Borders, Frontiers, and the Dialectics of Inclusion and Exclusion}

Taken together, 39 borders comprising 52,752 kilometers divide the Americas into different political territories (Bernecker 29). Many of these borders, however, historically divided sparsely or even unpopulated hinterland and remained rather irrelevant in political terms (Sandner). The Americas are the only place in the world where "a land border joins a developing Third World nation with a post-industrial First World country” (Herzog 4). Chicana writer Gloria Anzaldúa has famously described this border that includes some of the most densely populated border zones worldwide as a "1,950 mile-long open wound [...] where the Third World grates against the first and bleeds. And before a scab forms it hemorrhages again, the lifeblood of two worlds merging to form a third country-a border culture" (Anzaldúa, Borderlands 2-3). On a conceptual level, border and territory form a pair of twins that for a long time have been linked to statehood (Giddens; for an overview, see Sack; Anderson). Only recently, the emphasis shifted from borders to boundaries and opened new space for discussion as borders mainly emphasize the dividing and separating function. Boundaries, in contrast, "constitute lines of separation or contact. This may occur in real or virtual space, horizontally between territories, or vertically between groups and/or individuals. The point of contact or separation usually creates an 'us' and an 'Other' identity, and this takes place at a variety of sociospatial scales" (Newman and Paasi 191). However, states are not the only group of actors imposing borders and boundaries. Overcoming methodological nationalism (Wimmer and Glick Schiller; Chernilo), scholars in critical geopolitics assert that "borders can be created, shifted, and deconstructed by a range of actors" (Rumford 164). At the same time, not only the border's function of divide, conquer, and control, but the process of borderwork itself comes to the fore.

From the very beginning, the discussion on borders in the Americas highlighted the changing nature of borders. Frederic Jackson Turner not only introduced his widely discussed concept of the frontier (Turner), but at the same time related it to the creation of American values such as democracy and 
individualism. Alistair Hennessy transferred Turner's ideas to Latin America (Hennessy). In contrast to Turner, who imagined his moving frontier as a linear process, Hennessy, however, was much more aware of the social interactions and overlapping that constitute the frontier. Indirectly, Hennessy anticipated a shift from defining spaces by looking at their centers towards looking at the peripheries and rimlands in order to draw conclusions for the center.

While this shift initially still reproduced the Weberian center-periphery models of statehood-even though the emphasis turned away from the center towards the "margins of the state" (Das and Poole), it finally provoked a highly productive discussion on hybrid "third spaces" (Bhabha). In the field of American studies, beginning in the late 1960s and throughout the 1970s, Mexican American critics and theorists interrogated the Turnerian narrative of the frontier as a central spatial framework and its link to the concept of democracy. They retold the expansionist movement into southwestern territories as a story of subjugation (e.g. Acuña), emphasizing that the concept of the frontier along with its narrative of civilization's movement from the eastern rim of the continent to its allegedly vacant western peripheries obscured the histories and cultures of the people in these peripheries. These critical voices were joined by those of historians such as Patricia Limerick and Annette Kolodny, who pointed out the limitations of the frontier myth and argued for a revised conception of the frontier as a "meeting ground" (Limerick 269), a space of "ongoing first encounters" (Kolodny 13) or a "contact zone" (Pratt 1992).

The 1980s witnessed a more general shift of critical attention from the spatial 'center' to the 'peripheries', privileging border zones such as the US-Mexican border (Saldívar, Dialectics and Border Matters, Anzaldúa, Borderlands). These spatial concepts emphasized the politics of location of peripheral spaces as sites of cultural production and of multiply rooted identities in concepts such as "frontera imaginary" (Saldívar, Border 12), "Queer Aztlán" (Moraga 147 ff), and "nepantla state" (Anzaldúa, "Border" 108; Mora). Walter Mignolo has introduced the notions of "border thinking" (Mignolo, Local 38) and "border gnosis" (13) to describe ways of thinking that move between different epistemologies and that acknowledge the multiple loci of enunciation from which knowledge is produced, thus deconstructing binaristic ways of thinking and logo- and ethnocentric global hierarchies of knowledge production. These concepts and approaches offer critical interventions into traditional narratives of "American" national identity and culture and interrogate the exceptionalist notions of the role of the United States on the continent. New attention has also been paid to spatialization processes in regions that had been neglected in the study of nation-states-the Caribbean rimlands or the Trans-Pacific - and that highlight 
America's links with other parts of the world, but that have also crucially contributed to "respatializing" the United States along a west-east or a south-north axis.

The borderlands are today recognized as "a place of incommensurable contradictions" and as an "interstitial zone of displacement and deterritorialization that shapes the identity of the hybrid subject" (Gupta and Ferguson 18). Borders in this regard are increasingly recognized as "sites of intensive marginality and creativity" (Woodward and Jones III 246). Nevertheless, acknowledging the productive character of borders and the hybrid identities that these borders give rise to does not necessarily eliminate the focus on power and control. Power still is an asymmetrical relationship, and even though creativity confronts authority, as Foucault insisted, it does not circumvent one of the central functions of borders: inclusion/exclusion.

Josef Raab in his essay describes the US-American/Mexican border as an essentially conflicted space of its own. Pointing to the fact that the border has always been a political construct and thus a contested space depending on the view of involved actors, he investigates the border as a turbulent and intercultural space. His essay identifies various approaches to this space as contestation, hybridization, and criminalization, each of which is driven by different agendas. Gabriele Pisarz-Ramirez likewise focuses in her chapter on a similar border region. She argues that in the light of expansionist US policies and slavery, Florida was often imagined as a zone of contact with the Caribbean yet at the same time as a perilous space. Her essay describes Florida as a hemispheric region that is characterized by its tropicality, a marker that works to distance the peninsula from the nation yet at the same time makes it desirable for incorporation. Looking at the 'other', but within the nation, shifts the focus in Megan Maruschke's chapter from the rimlands to processes of border-making and thereof emerging spaces of slavery within the US-American nation. She argues that bordering can be understood not only as an incentive to construct state sovereignty, but must be interpreted as a tool of state actors in constructing territorial political entities in order to institutionalize and exercise political power. Finally, Antje Dietze relates this idea of border-making to transnational theatrical economic relations between Canada and the United States. She argues that at the end of the nineteenth century, Canada increasingly contested the US-American dominance of cultural production. She shows that on the one hand, economic space evolves because cultural entrepreneurs monopolize their business, but at the same time-as business theory predicts-begin to control territories. These territories, however, develop apart from national borders and thus need to be understood as transnational networks beyond national control. 


\section{Transgressing Space: Globalization, Mobility, and Bordercrossings}

The question when, where, and under which conditions transnational spatialization processes involve the crossing or creating of borders is particularly relevant in the Americas. For instance, migration and financial flows but likewise Skype and Facebook connect particular places in the Americas. Transnational value and care chains affect both Latin as well as North America. However, do present processes of globalization weld together these different parts of the Americas or do they rather create divisions, for example between highly industrialized and less-developed countries? How should these emerging transnational spaces be defined: geo-strategically, culturally, historically, philosophically, geographically, politically, or as a combination of these and other approaches? Finally, which configurations emerge from such definitions? How do free trade zones, migrations, networks of drug trade, and violence and new currency flows such as remittances impact on turning national borders into new frontiers? What is the relationship between imagined border-crossings and existing or newly drawn borders and the discourses and life-worlds produced by them?

Transnational mobility and border-crossings do not necessarily abolish borders. Globalization literature has tended to envision the irrelevance of borders and highlighted the transnational as a potential alternative to national spatial configurations, producing images of a world that is "flat," that is a level playing field, as Thomas Friedman has suggested (Friedman, The World Is Flat). The early 2000s produced visions of a "Century of the Americas" where the significance of borders is shrinking, ${ }^{1}$ and border artists such as Guillermo Gómez-Peña provocatively declared the entire continent a post-national border zone (The New World Border). However, current processes more than ever suggest that border-crossing goes hand in hand with encapsulations and sealing. Exclusionary immigration restrictions, the criminalization of undocumented immigrants, the plans for a border wall at the US-Mexican border-all issued by the Trump administration-are just a few recent examples. Politics is, perhaps more than ever, engaged in controlling and even stopping migration, and internal borders, gated communities, and "cities of walls" (Caldeira) are on the rise. De-bordering and transnationalism in this regard permanently produce

1 For example, in a widely read Time Magazine issue, the thesis was proposed that in view of massive migration, free trade, and multiple economic and cultural connections between the United States and Mexico, the "American Century" could soon be replaced by a "Century of the Americas" (Gibbs). See also Fauriol and Weintraub. 
and reproduce (re)-bordering and re-nationalization. De-territorialization and re-territorialization complement each other (Brenner).

Hannes Warnecke-Berger takes up these ideas and shows in the case of Salvadoran migration to the United States and remittances flowing back to El Salvador that political and economic efforts to transnationalize often go hand in hand with processes of (re-)nationalization. Elaborating on the concept of rent and spaces of rent, he shows that transnational economic spaces are the product of moral economies in which both migrants and their home families develop strong forms of agency. The outcome, however, is by no means a flat and deliberative third space. In contrast, Warnecke-Berger shows that these transnational spaces are fueled by emotional stress, struggle over prestige, and the permanent threat of falling back into poverty.

Finally, transnational agency is the pivotal focus of Sebastian Huhn and Christoph Rass. While they initially focus on the de-bordering and de-territorializing factors of refugee flows after World War II, they continue to argue that refugees and migrants not only challenge given forms of political territoriality, but often develop yet undiscovered forms of agency. Migrants and refugees, even if they are forced to migrate, are thus transnational actors in shaping both politics and territoriality in their spaces of arrival and in the spaces where they previously lived.

What are the Americas? We began this introduction with Waldseemüller's map, the first visualization and imagination of America in world history. The map gave a name to an immense land mass and to millions of people living on this land. Although this is an important process that must be acknowledged, we need to keep in mind that Waldseemüller never saw America, he "only" put the name on the map. As this example makes clear, the imagination and the naming of space is often disconnected from the very experience of living in the respective space-both empirically and in analytical terms. What is at stake is agency, but at the same time, as some of the contributors in this book have pointed out, it is a question of who is allowed to speak, to define, and to map space.

Even though the spatial turn started as one of the cultural turns in the social sciences and humanities (Bachmann-Medick), the ontological quality of "space" still remains unclear (Werlen 369). Although the spatial turn has opened the view on the variegated, formerly often undiscovered or even neglected forms of agency in the process of space-making, it has rarely accounted for the success of all these different processes of space-making, and it almost never compares these different efforts. While theories of agency that have been privileged by the spatial turn have foregrounded the diversity of actors engaged in space-making, these theories hardly ever address the question if those who voice their ideas 
about space are being heard and to whom actors tend to listen. This question is deeply related to acknowledging processes of power and the asymmetric nature of space-making, as well as the often coercive practices of delineating and protecting the space in which somebody lives. These power dynamics are, however, highly relevant in space-making processes in the Americas, as the chapters in this volume on the 'dark sides' of space-making, such as domination, violence, and slavery, point out.

A final issue in researching space then concerns methodology. For a long time, scholars tried to uncover the "essence" of spaces, and authors tended to look at space from its very center. In physics, this perspective is closely linked to the work of Newton, and in the social sciences to Max Weber. It was at this center, it was argued, that the nature of a space, its form or its essence, was revealed. As for the Americas, this theoretical perspective results in questions such as "What do the different parts of the Americas have in common?" or in our initial question, "What are the Americas?"

In recent times, attention has shifted from the centers to the margins in an attempt to revise essentialist perspectives on regions, nations, and cultures. This focus on the peripheries, borders, frontiers, and rimlands has uncovered not only the many connections, mobilities, and relationships between the different spaces of the Americas, but also the multiple processes of exclusion that have accompanied attempts to define coherent collective national identities.

This approach makes an important intervention into essentialist approaches. It argues that spatial construction never happens in a vacuum but always depends on difference. This difference becomes most evident on borders and boundaries, where the lines of inclusion and exclusion are drawn. The shift of attention from centers to peripheries also accentuated the epistemological productivity of borders and boundaries as spaces where the cultural norms of the center and ontological statements on the essence of space are questioned. However, this perspective still rests on the center-periphery dualism of Newton and Weber, merely focusing on the other side and to a certain extent reproducing ontological assumptions on space.

Finally, a third methodological perspective looks at the transgression of borders between different spaces. In theory, this perspective is closely related with the work of George Bataille (see for an overview, e.g. Hetzel and Wiechens). The Bataillan perspective entertains some doubts both about the essentialist and about the anti-essentialist perspective. Taking the concept of transgression as a starting point, Bataille argues that both perspectives rather complement each other. This suggests that the focus of research should not be the investigation of the essence of space or the lack of this essence but rather the exploration of the shifting borders 
and the interdependencies between spaces of inclusion and exclusion, as well as the dynamics of when, where, and why essence emerges or breaks down. This can be read both as an epistemological appeal not to fix the researcher's perspective in the first place and as an ontological appeal to not only look at the constructions of space but at the same time to rethink the forming role of space for human interaction and imagining. It remains clear that each methodological perspective has its own strengths and flaws. But rather than deciding for one or the other approach, it appears to be more productive to think about how to combine them. In this sense, this collection of essays does not only address the Americas. The volume that brings together social scientists, historians, cultural studies, and American studies scholars to discuss processes of spatialization in the Americas also hopes to broaden the view on the different perspectives on this topic.

\section{References}

Acuña, Rodolfo. Occupied America: The Chicano's Struggle toward Liberation. Canfield Press, 1972.

Anderson, Malcolm. Frontiers: Territory and State Formation in the Modern World. Polity Press, 1996.

Anzaldúa, Gloria E. Borderlands/La Frontera: The New Mestiza. Aunt Lute Books, 1987.

Anzaldúa, Gloria E. “Border Arte: Nepantla, el lugar de la frontera.” La Frontera/ The Border: Art about the Mexico/United States Border Experience, edited by Patricio Chávez et al., Museum of Contemporary Art, 1993, pp. 107-14.

Bachmann-Medick, Doris. Cultural Turns: Neuorientierungen in den Kulturwissenschaften. Reinbek b. Hamburg: Rowohlt, 2006.

Bernecker, Walther L. "Staatliche Grenzen-kontinentale Dynamik: Zur Relativität von Grenzen in Lateinamerika." Grenzen der Macht-Macht der Grenzen: Lateinamerika im globalen Kontext, edited by Marianne Braig et al., Vervuert, 2005, pp. 11-37.

Bhabha, Homi K. Die Verortung der Kultur. Stauffenburg, 2000.

Blaut, James M. The Colonizer's Model of the World: Geographical Diffusionism and Eurocentric History. Guilford Press, 1993.

Boeckh, Andreas. "Dependencia und kapitalistisches Weltsystem, oder: Die Grenzen globaler Entwicklungstheorie und Entwicklungspolitik." DritteWelt-Forschung: Entwicklungstheorie und Entwicklungspolitik, edited by Franz Nuscheler, Westdeutscher Verlag, 1985, pp. 56-74.

Bolton, Eugene. “The Epic of Greater America." American Historical Review, vol. 38 , no. 8,1933 , pp. $448-74$. 
Brenner, Neil. "Beyond State-Centrism? Space, Territoriality, and Geographical Scale in Globalization Studies." Theory and Society, vol. 28, no. 1, 1999, pp. 39-78.

Burke, Peter. Kultureller Austausch. Suhrkamp, 2002.

Caldeira, Teresa P. R. City of Walls: Crime, Segregation, and Citizenship in São Paulo. University of California Press, 2000.

Chernilo, Daniel. "Social Theory's Methodological Nationalism: Myth and Reality." European Journal of Social Theory, vol. 9, no. 1, 2006, pp. 5-22.

Das, Veena, and Deborah Poole, editors. Anthropology in the Margins of the State. School of American Research Press, 2004.

Dickson, Peter W. The Magellan Myth: Reflections on Columbus, Vespucci, and the Waldseemueller Map of 1507. Printing Arts Press, 2007.

Dussel, Enrique. Beyond Philosophy: Ethics, History, Marxism, and Liberation Theology. E. Mendieta (ed.) Lanham, MD: Rowman and Littlefield Publishers, 2003.

Edwards, B. T., and D. P. Gaonkar. "Introduction: Globalizing American Studies." Globalizing American Studies, edited by B. T. Edwards and D. P. Gaonkar, University of Chicago Press, 2010, pp. 1-44.

Espagne, Michel. "Sur les limites du comparatisme en histoire culturelle." Genèses, vol. 17, 1994, pp. 112-21.

Fauriol, Georges A., and Sidney Weintraub. "The Century of the Americas: Dawn of a New Century Dynamic." The Washington Quarterly, vol. 24 , no. 2, 2001, pp. 139-48.

Friedman, Thomas L. The World Is Flat: A Brief History of the Twenty-First Century. Farrar Straus and Giroux, 2005.

Gibbs, Nancy. "A Whole New World: Along the US-Mexican Border, Where Hearts and Minds and Money and Culture Merge, the Century of the Americas Is Born." Time, 11 June 2001, content.time.com/time/world/ article/0,8599,2056107,00.html/.

Gibson-Graham, J. K. "Area Studies after Poststructuralism." Environment and Planning A, vol. 36, no. 3, 2004, pp. 405-19.

Giddens, Anthony. The Nation-State and Violence: A Contemporary Critique of Historical Materialism. vol. 2, University of California Press, 1987.

Gilroy, Paul. The Black Atlantic: Modernity and Double Consciousness. Harvard University Press, 1993.

Gómez-Peña, Guillermo. The New World Border. Prophecies, Poems \& Loqueras for the End of the Century. San Francisco: City Lights, 1996. 
Gupta, Akhil, and James Ferguson. “Beyond 'Culture’: Space, Identity, and the Politics of Difference." Cultural Anthropology, vol. 7, no. 1, 1992, pp. 6-23. Hanke, Lewis, editor. Do the Americas Have a Common History? A Critique of the Bolton Theory. Knopf, 1964.

Hennessy, Alistair. The Frontier in Latin American History. Edward Arnold, 1978. Herzog, Lawrence A. "Changing Boundaries in the Americas: An Overview." Changing Boundaries in the Americas: New Perspectives on the US-Mexican, Central American, and South American Borders, edited by Lawrence A. Herzog, Center for US-Mexican Studies, University of California San Diego, 1992, pp. 3-24.

Hetzel, Andreas, and Peter Wiechens, editors. Georges Bataille: Vorreden zur Überschreitung. Königshausen \& Neumann, 1999.

Hirsch, Rudolph. "Printed Reports on the Early Discoveries and their Reception." First Images of America: The Impact of the New World on the Old: Volume II, edited by Fredi Chiappelli, University of California Press, 1976, pp. 537-62.

Kaplan, Amy, and Donald Pease, editors. Cultures of United States Imperialism. Duke University Press, 1993.

Kolodny, Annette. "Letting Go Our Grand Obsessions: Notes toward a New Literary History of the American Frontiers." American Literature, vol. 64, no. 1, 1992, pp. 1-18.

Lefebvre, Henri. The Production of Space. 1974. Blackwell, 1991.

Limerick, Patricia. The Legacy of Conquest: The Unbroken Past of the American West. Norton, 1987.

Menzel, Ulrich. Das Ende der Dritten Welt und das Scheitern der großen Theorie. Suhrkamp, 1992.

Mignolo, Walter D. Local Histories, Global Designs: Coloniality, Subaltern Knowledges, and Border Thinking. Princeton University Press, 2000.

Mignolo, Walter D. The Idea of Latin America. Blackwell, 2005.

Mora, Pat. Nepantla: Essays from the Land in the Middle. University of New Mexico Press, 1993.

Moraga, Cherrie. The Last Generation: Prose and Poetry. South End Press, 1993.

Newman, David, and Anssi Paasi. "Fences and Neighbours in the Postmodern

World: Boundary Narratives in Political Geography." Progress in Human Geography, vol. 22, no. 2, 1998, pp. 186-207.

Newton, Isaac. Philosophiae Naturalis Principia Mathematica: Third Edition (1726) with Variant Readings. Edited by Alexandre Koyré and Bernard I. Cohen, Harvard University Press, 1972. 
Nuscheler, Franz. Lern- und Arbeitsbuch Entwicklungspolitik: Eine grundlegende Einführung in die zentralen entwicklungspolitischen Themenfelder Globalisierung, Staatsversagen, Armut und Hunger, Bevölkerung und Migration, Wirtschaft und Umwelt. 7th ed., Dietz, 2012.

O'Gorman, Edmundo. The Invention of America: An Inquiry into the Historical Nature of the New World and the Meaning of its History. Greenwood Press, 1961.

Padrón, Ricardo. "Mapping Plus Ultra: Cartography, Space, and Hispanic Modernity." Representations, vol. 79, no. 1, 2002, pp. 28-60.

Padrón, Ricardo. The Spacious Word: Cartography, Literature, and Empire in Early Modern Spain. University of Chicago Press, 2004.

Pérez Caldentey, Esteban, and Matías Vernengo. "Back to the Future: Latin America's Current Development Strategy." Journal of Post Keynesian Economics, vol. 32, no. 4, 2010, pp. 623-44.

Pérez Firmat, Gustavo, editor. Do the Americas Have a Common Literature? Duke University Press, 1990.

Pratt, M. L. Imperial Eyes: Travel Writing and Transculturation. Routledge, 1992. Quijano, Aníbal. "Coloniality of Power, Eurocentrism, and Latin America." Nepantla: Views From South, vol. 1, no. 3, 2000, pp. 533-80.

Rabasa, José. Inventing America: Spanish Historiography and the Formation of Eurocentrism. University of Oklahoma Press, 1993.

Randles, W. G. L. "Classical Models of World Geography and Their Transformation Following the Discovery of America." European Images of the Americas and the Classical Tradition, edited by Wolfgang Haase and Reinhold Mayer, De Gruyter, 1994, pp. 5-76.

Roach, Joseph. Cities of the Dead: Circum-Atlantic Performance. Columbia University Press, 1996.

Rowe, John C. "Post-Nationalism, Globalism and the New American Studies." Post-Nationalist American Studies, edited by John Carlos Rowe, University of California Press, 2000, pp. 23-39.

Rowe, John C. "Areas of Concern: Area Studies and the New American Studies." Alif: Journal of Comparative Poetics, vol. 31, 2011, pp. 11-34.

Rumford, Chris. “Theorizing Borders." European Journal of Social Theory, vol. 9, no. 2, 2006, pp. 155-69.

Sack, Robert D. Human Territoriality: Its Theory and History. Cambridge University Press, 1986.

Said, Edward W. Orientalism. Vintage Books, 1979.

Saldívar, José D. The Dialectics of Our America: Genealogy, Cultural Critique, and Literary History. Duke University Press, 1991. 
Saldívar, José D. Border Matters: Remapping American Cultural Studies. University of California Press, 1997.

Sandner, Gerhard. "Die Territorialitätsgrenze als Trennlinie und Zusammenfassung in Anglo- und Lateinamerika: Ein Vergleich aus politisch-geographischer Sicht." Nord und Süd in Amerika: Gemeinsamkeiten-Gegensätze-Europäischer Hintergrund, edited by Wolfgang Reinhard and Peter Waldmann, Rombach, 1992, pp. 78-95.

Schäbler, Birgit. "Einleitung: Das Studium der Weltregionen (Area Studies) zwischen Fachdisziplin und der Öffnung zum Globalen: Eine wissenschaftsgeschichtliche Annäherung." Area Studies und die Welt: Weltregionen und neue Globalgeschichte, edited by Birgit Schäbler, Mandelbaum, 2007, pp. 11-44.

Schwartz, Seymour I. Putting "America" on the Map: The Story of the Most Important Graphic Document in the History of the United States. Prometheus Books, 2007.

Spivak, Gayatri C. "Can the Subaltern Speak?” Marxism and the Interpretation of Culture, edited by Cary Nelson and Lawrence Grossberg. Urbana, IL: University of Illinois Press, 1988, pp. 271-313.

Turner, Frederick J. The Frontier in American History. 1893. Holt, Rinehart and Winston, 1962.

Waldseemüller, Martin. Cosmographiae Introductio. 1507. English Translation by Joseph Fischer Franz von Wieser, The United States Catholic Historical Society, 1907. Facsimile Edition edited by Charles George Herberman. Archive, archive.org/details/cosmographiaeint00walduoft/.

Werlen, Benno. “Körper, Raum und mediale Repräsentation." Spacial Turn: Das Raumparadigma in den Kultur- und Sozialwissenschaften, edited by Jörg Döring and Tristan Thielmann, transcript, 2008, pp. 365-92.

Werner, Michael, and Bénédicte Zimmermann. "Beyond Comparison: Histoire Croisée and the Challenge of Reflexivity." History and Theory, vol. 45, no. 1, 2006, pp. 30-50.

Wimmer, Andreas, and Nina Glick Schiller. "Methodological Nationalism and Beyond: Nation-State Building, Migration and the Social Sciences." Global Networks, vol. 2, no. 4, 2002, pp. 301-34.

Woodward, David. "Maps and the Rationalization of Geographic Space." Circa 1492: Art in the Age of Exploration, edited by Jay A. Levenson, Yale University Press, 1991, pp. 83-87.

Woodward, Keith, and John Paul Jones III. "On the Border with Deleuze and Guattari." B/ordering Space, edited by Henk van Houtum et al., Ashgate, 2010, pp. 235-48. 


\section{Producing Space: The Americas between Homogeneity and Heterogeneity}





\title{
Peter Birle
}

\section{Regionalism and Regionalization in Latin America: Drivers and Obstacles}

\begin{abstract}
Regional cooperation in Latin America and the Caribbean has increased significantly in the past twenty-five years, leading to the emergence of a variety of new bilateral and multilateral cooperation and integration mechanisms. Despite some success, however, there are still strong fragmentation tendencies in the region. This chapter is concerned with the question of why Latin America, despite its efforts to achieve regional cooperation and integration going back to the early nineteenth century, still struggles to make regionalism a lasting success. First, there is a brief discussion of the concepts of "region," "regionalization," and "regionalism." The chapter then gives an overview of the historical development of processes of regional cooperation and integration in Latin America and describes the array of organizations and blueprints that exist today. The second part discusses the current situation of regional organizations in the light of new political developments since 2015 . We then ask for explanations why there is a big gap between the objectives and reality of Latin American regionalism. In this context, central importance is attached to the development strategies prevailing in the region, the dominant concepts of sovereignty, and the specific features of regionalization in Latin America.
\end{abstract}

\section{Introduction}

This chapter is concerned with the question of why Latin America, despite its efforts to achieve regional cooperation and integration going back to the early nineteenth century, still struggles to make regionalism a lasting success. The central concepts of region, regionalism, and regionalization are defined according to The Oxford Handbook of Comparative Regionalism. Consequently, a region is not understood as 'natural' or as an objective category, but as a social construction. Regions are "made, remade, and unmade-intentionally or non-intentionallyin the process of global transformation, by collective human action and identity formation" (Söderbaum 28). Börzel and Risse define regions "as social constructions that make references to territorial location and to geographical or normative contiguity" ("Introduction" 7). The term 'Latin America' is a good example of such a social construction. It is an ethnic-geographical concept that was invented in the 19th century by French scientists to identify a region of the American continent with a majority of languages derived from Latin (mainly Spanish or Portuguese and to a lesser extent French). Since the late 19th century, 
intellectuals have used the term in the sense of delimiting 'Our America' from the hegemonic power of the United States. In the wake of a growing self-confidence of many indigenous peoples on the American continent, the term "Latin America" has repeatedly been criticized as Eurocentric, due to the exclusion that it makes of a large number of languages and ethnicities in several countries and regions of the so-called Latin America.

The default term for all countries in the Americas except the United States and Canada is 'Latin America and the Caribbean' (LAC). The reference to the continent as a whole is made as 'The Americas' or as 'Western Hemisphere'. For geographical subspaces, terms such as South America, the Andean region, Central America, the Caribbean, the Caribbean Basin, and North America are common. By contrast, constructs such as Mesoamerica and Indo-America refer to the indigenous roots and cultures of the continent. Different regional concepts are occasionally used with political intentions. For example, the idea of a 'South American area' whose interests differ from the rest of the continent has gained importance in Brazil's foreign policy thinking since the mid-20th century, and especially since the 1980s. Such a perspective dominated the La Plata basin treaties in the 1960s and the Amazonian cooperation of the 1970s. This was accompanied by a growing distance from the United States, the traditional ally of Brazil in the Western Hemisphere. At the beginning of the 21st century, the then Brazilian foreign minister Celso Lafer argued that South America was a physical entity that offered many opportunities for economic cooperation. Mexico, on the other hand, in his view was becoming more and more intertwined with the North due to its participation in the North American Free Trade Agreement (NAFTA) as well as Central America and the Caribbean, which are much more affected by the magnetism of the North American economy. Lafer saw the future of this part of Latin America, therefore, mainly related to what is happening in the United States. South America, on the other hand, would have more diversified regional and international relations, both politically and economically. This would require appropriate foreign policy consequences (Lafer 55).

This chapter distinguishes between regionalism and regionalization. Following Börzel and Risse, regionalism is understood as "constituting a primarily state-led process of building and sustaining formal regional institutions and organizations among at least three states" ("Introduction" 7). In contrast, the term "regionalization" refers to "processes of increasing economic, political, social, or cultural interactions among geographically or culturally contiguous states and societies" (8). Regionalization refers, above all, to transnational, 'bottom up' activities of non-state actors such as interest groups, social movements, enterprises, 
and non-governmental organizations. However, cross-border criminal activities such as smuggling, drug trafficking, and trafficking are also part of regionalization. The specific combination of features of regionalization and regionalism is referred to as 'regional order.' Börzel and Risse distinguish three types of regional orders: those where degrees of regionalization and regionalism correlate (Europe, Southeast Asia, Eurasia, and the Middle East); those with high levels of regionalization, but limited regionalism (North America, Northeast Asia); and those with low-to-medium degrees of regionalization, but stronger regionalism (Africa, Latin America) ("Three Cheers" 628-29). As the text will show, however, the notion of "strong regionalism" in Latin America can easily be misleading. There are many regional and sub-regional forms of cooperation in many areas, but the regional organizations that have emerged in this context usually have little authority.

The chapter is structured as follows. The first part gives an overview of the historical development of processes of regional cooperation and integration in Latin America and briefly describes the array of organizations and blueprints that exist today. The second part discusses the current situation of regional organizations in the light of new political developments since 2015. The third part presents some characteristic elements that define the current cooperation and integration processes that might help us to better understand why the gap between objectives and achievements in Latin American regionalism is oftentimes quite wide. In this context, central importance is attached to (a) the development strategies prevailing in the region, (b) the dominant concepts of sovereignty, and (c) the specific features of regionalization in Latin America. The chapter ends with some general conclusions. ${ }^{1}$

1 This chapter was written as part of the activities under the project "Giving focus to the Cultural, Scientific and Social Dimension of EU-CELAC Relations" (EULAC Focus). It is a collaborative project funded by the Executive Agency of the European Research Council, Horizon 2020, between 2016 and 2019, under Convention No. 693781. The project involves 19 institutions, 9 from Europe and 10 from Latin America and the Caribbean. Its main objective is to "give focus" to EU-CELAC relations. The Ibero-Amerikanisches Institut coordinates a work package on four cross-cutting issues: mobility, inequality, diversity, and sustainability. Each one is analysed for the cultural, scientific, and social dimension. In addition, overlaps and interconnections between the four cross-cutting issues are explored. For more information about the project, see the website $<$ http://eulac-focus.net/ $>$. 


\section{The Historical Development of Latin American Regionalism}

In Europe, it is often assumed that the process of European integration that started in the 1950s became a model for integration processes in other parts of the world. While partly true, it should not be forgotten that the discussion on regional cooperation and integration in Latin America dates back to the period of independence in the early 19th century. Examples of such integration efforts were confederate entities such as Greater Colombia (1819/1823-1830), the Central American Confederation (1823-1839), or the Peruvian-Bolivian Confederation (1836-1839). In his Carta de Jamaica (letter from Jamaica), the liberator Simón Bolívar in 1815 pointed to the need for close cooperation between the Hispano-American states. Only then would the region be able to assert itself against external powers. During the Panama Congress of 1826, Greater Colombia, Mexico, Peru, and the Central American Confederation signed a Union treaty that was never ratified. If Bolívar's vision of a unified Hispanic America did not materialize, it would be because of growing rivalries between some of the young nation states in the region. Nonetheless, the issue of regional unity remained present in the political debates and was revisited, for example, during the Lima Congress (1847-1848) and in the late 19th century in the course of discussions on Pan-Americanism and the Pan-American Conferences. ${ }^{2}$

Since the 19th century, there have been two competing visions of regionalism in the Americas that have been present in discussions to this day: 'PanAmericanism' versus 'Latin American Unity.' The idea of Pan-Americanism stands for close co-operation among all countries of the Western Hemisphere, including the United States and Canada. It was mainly supported by the United States and led to 10 Pan-American conferences that took place between 1889 and 1954. The idea of Pan-Americanism was institutionalized after the Second World War with the Inter-American System. In addition to the Organization of American States (OAS), founded in 1948, this system includes institutions such as the Inter-American Court of Human Rights and the Inter-American Development Bank as well as treaties such as the American Treaty on Pacific Settlement. The idea of a Free Trade Area of the Americas (FTAA), launched in 1991 by the then US president George Bush, was also in line with the idea of PanAmericanism, with the United States always playing a leading (hegemonic) role.

2 For the history of Latin American regionalism, see Barrios; Birle, "Zwischenstaatliche Konflikte," "Zwischen Integration”; Briceño-Ruiz, "Autonomía”; Mols, Integration und Kooperation in Lateinamerika, Integration und Kooperation in zwei Kontinenten. 
By contrast, already early in the 19th century, the idea of a 'southern' cooperation designed to increase the region's autonomy vis-à-vis the United States developed. Simón Bolívar envisioned a united Hispano-America to counteract US hegemonic claims. He also had no great confidence in Brazil, which emerged in 1822 from the Portuguese colonial empire. ${ }^{3}$ At the end of the 19th/beginning of the 20th century, thinkers such as José Martí and José Enrique Rodó combined the idea of a unified Latin America with internationalist and anti-imperialist ideas. Unlike the Pan-American idea, however, the idea of Latin American unity did not lead to the formation of formal institutions until the 21st century. Antiimperialist thinking directed against the United States was re-issued from the late 1990s with Bolivarism propagated by the then Venezuelan president Hugo Chávez. With the founding of the Comunidad de Estados Latinoamericanos $y$ Caribeños (CELAC) in 2011, all the sovereign states of the Americas except Canada and the United States joined forces for the first time.

For a long time, Latin American regionalism was largely characterized by efforts to reduce trade barriers between the countries of the region. In the first half of the 20th century, economists such as Alejandro Bunge (1880-1943) and Raúl Prebisch (1901-1986) developed plans for regional economic integration to overcome obstacles to national and regional development. As secretary general of the United Nations' Economic Commission for Latin America and the Caribbean (ECLAC; the Spanish acronym is CEPAL) from 1950 to 1963, Prebisch gave decisive impulses for the theoretical discussion about development in Latin America. Under his leadership, CEPAL recommended to the Latin American countries a development strategy based on a combination of import-substituting industrialization and regional integration. A well-balanced economic development was expected to emerge in the region by means of the liberalization of intra-Latin American commerce and the simultaneous application of a protectionist policy in relation to extra-regional trade. ${ }^{4}$ That should

3 Mistrust was quite mutual. The political elites of the Empire of Brazil regarded the repeated unrest in South America as an expression of anarchy and disorder, as in their view they were typical of the republican form of government. Accordingly, their position towards the Hispano-American republiquetas (small republics) was characterized by disinterest and a sense of superiority. For their part, the Hispanic-American countries criticized the Brazilian Empire for its 'backward' institutions and for the until 1888 ongoing slavery (Capelato 289-92). A first 'Americanization' of Brazilian foreign policy in the sense of a turn to the countries of the Western Hemisphere began only with the establishment of a republican state system in 1889 (Lafer 36).

4 For the original CEPAL doctrine, see Deciancio, Zimmerling. 
also help to foster structural transformation and create productive capacities of industrial enterprises in the region. 'Cepalismo' required a deliberately political approach to regionalism. In 1960, the Latin American Free Trade Association (ALALC) was founded. Its initial objective was to establish a free trade zone between its members within 12 years. ${ }^{5}$ Despite initial success, this goal soon came out of sight. The dissatisfaction of the smaller countries with the result of regional economic integration led to sub-regional integration efforts such as the Common Central American Market and the Andean Pact (renamed the Andean Community in 1996).

At the latest, with the beginning of the debt crisis in the 1980s, the CEPAL developmental discourse entered into crisis. CEPAL responded by revising their concepts, and starting in the 1990s, they proposed a concept of 'growth with equity', speaking of regional integration characterized by 'open regionalism.' While the original CEPAL doctrine had considered protectionist measures necessary to shield national industries against the world market, regional economic integration now was considered as a trampoline off of which one could bounce into the global market. CEPAL recommended the reduction of tariff and nontariff barriers within Latin America. The opening to the global market should be combined with the maintenance of certain preferences towards regional and sub-regional trading partners. In addition, joint Latin American rules should be established for the circulation of goods, services, and investments, as well as for the protection of intellectual property and public procurement. Furthermore, CEPAL recommended a gradual adjustment of the trade, competition, fiscal, and monetary policies of the individual states within the region, as well as the realization of active efforts to reduce asymmetries between states. To assure the success of these objectives, the institutional foundations of regional integration was to be systematically fortified (Thiery).

In the following years, while the concept of open regionalism became the rhetoric of regional integration, the Latin American governments de facto implemented only those parts of the strategy aimed at liberalizing and deregulating markets. By contrast, those elements that would have resulted in strengthening regional institutions and common policies were almost completely

5 Member countries of the ALALC were Argentina, Bolivia, Brazil, Chile, Ecuador, Colombia, Mexico, Paraguay, Peru, Uruguay, and Venezuela. In 1980, the organization was renamed as Latin American Integration Association (Asociación Latinoamericana de Integración, ALADI). Besides the founding members, ALADI also includes Cuba (since 1999) and Panama (since 2012). All Latin American countries can become members. 
ignored. In this respect, most Latin American governments followed the neoliberal concepts of the 'Washington Consensus' promoted by the International Monetary Fund (IMF) and the World Bank in the 1990s.

Sub-regional integration gained new momentum in 1991 with the creation of Mercosur (Mercado Común del Sur) between Argentina, Brazil, Paraguay, and Uruguay. Intra-regional trade among member countries increased sharply in the early years, but from 1997, the integration process stalled. To date, Mercosur has failed to develop strong institutions and to move closer to the original objective of creating a common market than is the case in the existing incomplete Customs Union. Nevertheless, for all Mercosur economic integration issues, the contribution of the organization to strengthening cross-border cooperation between governments and civil society actors in the member states should not be underestimated. Amongst these achievements, it is worth mentioning a few standouts: for example, the incorporation of the 'democracy clause'; the creation of a 'zone of peace' in the Southern Atlantic; the creation of a citizen community in Mercosur; and the progress made in terms of societal participation in the integration processes that has given way to new policies of 'paradiplomacy.' The international experience of localized administrations (municipal, provincial, and state) and the formation of regions - national, border, and internationalare at the heart of paradiplomacy in South America. Mercosur, with its own special dynamic, has also made advancements in this practice, thanks to the gains in representation seen in local societies.

Since the 1990s, the dynamics of intra-Latin American economic integration have been increasingly hampered by processes and cooperative negotiations with external partners. In 1994, Mexico, Canada, and the United States signed into the NAFTA (in Spanish TLCAN). In the same year, negotiations over the creation of a FTAA (in Spanish ALCA), which were encouraged by the United States, began. Shortly after, negotiations began for the creation of an agreement of association between the European Union (EU) and Mercosur.

The dissatisfaction of large sections of Latin American societies with the results of the neoliberal reforms of the 1980s and 1990s, which provided macroeconomic stability and growth in many countries, but produced neither social improvements nor distributive justice, led to a 'turn to the left' at the beginning of the 21st century in Latin American politics. However, the new governments were anything but homogenous. Some were more in keeping with conservative social democracy, others combined macroeconomic stability policies and progressive social policies, and others proclaimed '21st century socialism.' The common denominator of the left-wing governments was the rejection of neoliberal dogmas, the desire for more autonomy, especially towards the long-standing 
hegemonic power of the United States, as well as the quest for more Latin American power in the international system. In contrast, there were severe differences between the individual countries with regard to national development strategies and concepts for incorporation into the international system.

It was precisely this combination of serious strategic divergences within the region on the one hand and the political desire for more regional cooperation on the other hand that led to the emergence of several new regional organizations and networks in the following years. These include the Union of South American Nations (Unión de Naciones Suramericanas, UNASUR), the Bolivarian Alliance for the Peoples of our America (Alianza Bolivariana para los Pueblos de Nuestra América, ALBA), the Latin American and Caribbean Community (Comunidad de Estados Latinoamericanos y Caribeños, CELAC), and the Pacific Alliance (Alianza del Pacifico, AP). A fundamental feature of these new institutions was that, in contrast to the earlier integration processes, which were heavily focused on trade issues, they also highlighted other aspects of economic cooperation and political issues. ${ }^{6}$

\subsection{UNASUR}

UNASUR, founded in 2008, includes all 12 independent states of South America: Argentina, Bolivia, Brazil, Chile, Ecuador, Guyana, Colombia, Paraguay, Peru, Suriname, Uruguay, and Venezuela. According to Article 2 of the founding treaty, the central goal of the organization is as follows:

The Union of South American Nations aims to construct a space of cultural, social, economic and political integration and union between their peoples in a participatory and consensus-oriented manner. Its priorities include political dialogue, social policies, education, energy, infrastructure, financing and the environment, with the aim of eliminating socioeconomic inequality, enabling social inclusion and civic participation, strengthening democracy and to reduce the asymmetries, all in the context of strengthening the sovereignty and independence of States. (UNASUR; author's translation)

UNASUR was created with the ambition of constructing an innovative integration process that goes beyond the mere convergence seen in Mercosur and the Andean Community, even though its constitutive treaty does not disclose exactly what this innovative element might look like in reality. The

6 For a general overview of recent processes of regional cooperation, see Briceño-Ruiz, "Ejes”; Gardini; Legler; Nolte, Latin; Portales; Riggirozzi; Sanahuja, "Regionalismo"; SELA, Estado; Tussie. 
institutional structure of UNASUR follows a purely inter-governmental logic. Neither the Secretary General nor the pro-tempore presidency has decision-making powers. All decisions must be made by a consensus between the presidents of the member states. Since its creation, UNASUR has demonstrated a strong ideological and economic pragmatism: the condition for membership is not a common conception of development strategies or international insertion, but rather regional membership: belonging to the South American region. The whole range of pre-existing tariff/tax policies has been accepted into the organization: CAN, MERCOSUR, CARICOM, and Chile. An important achievement of UNASUR is that they have incorporated security and defense into the regionalist agenda. Furthermore, they initially demonstrated an important political capacity to resolve, from within the region itself, intra-regional problems, bilateral problems between states, and problems of national politics that might threaten the regional politico-institutional order. Amongst the organization's deficits are its multiple institutional weaknesses: above all, the restrictive roles created for international representation, which are assigned to the Secretary General and the President pro-tempore. ${ }^{7}$

\subsection{ALBA}

The Bolivarian Alternative (now: Alliance) for the Peoples of Our America (ALBA) was created by the deceased Venezuelan president Hugo Chávez and arose as the direct antithesis of the project proposed by the United States (which has since been sidelined) to create a Pan-American zone of free trade (ALCA). Member countries of ALBA are Venezuela, Cuba, Bolivia, Ecuador, Nicaragua, and Surinam as well as a number of small Caribbean states. Concerning its programmatic foundations, ALBA does not only present a fundamental criticism of the United States and traditional Latin American liberalism, but it also proposes a social transformation that was born from a critique of neoliberalism and capitalism. ALBA aims to inspire a regional integration based on the ideas of Simón Bolívar and on the fundamental principles of cooperation, complementarity, mutual help, and solidarity. Even though the treaties and joint declarations signed within the ALBA framework often allude to a new form of solidary integration, they do not actually speak of a multilateral regime, but rather of a set of bilateral cooperation agreements between Venezuela and the other participant countries. No further integration is planned in the sense of establishing common institutions, much less supranational ones. Theoretically,

7 For UNASUR see Comini and Frenkel; Diamint; Sanahuja, Post-Liberal. 
ALBA proposes a vision of integration of peoples rather than individual nations. Nonetheless, in reality, ALBA continues to basically be an inter-governmental, if not inter-presidential, process. In fact, no real consultation or decision-making spaces have been allocated to political, technical, business, trade union, or civil society sectors.

The creation of ALBA was intended to consolidate Húgo Chávez' regional leadership, and its future is strongly intertwined with the destiny of Venezuela (which was the donor of practically all of the alliance's resources destined for economic cooperation and development).

\subsection{CELAC}

Created in 2010, CELAC covers all 33 Latin American and Caribbean countries, including Cuba, whose membership in the hemispheric OAS has been suspended since 1962. In terms of its members, CELAC is something of an OAS without the United States and Canada. Indeed, some of the ALBA member countries saw CELAC as an alternative to the OAS. The US attitude towards Cuba, and OAS' repeated instrumentalization for the implementation of US-led Latin American policy during the Cold War resulted in that many in Latin America still view the organization as a symbol of US hegemony. The founding of CELAC was thus an important symbolic step in the sense of the Latin American autonomy efforts against the long-standing hegemonic power. Nevertheless, the OAS continues to exist as the vast majority of Latin American governments did not join the position of those ALBA countries that advocated leaving the OAS.

CELAC's objective is to enlarge and consolidate sustainable development, peace, and cooperation. From the former Rio Group, CELAC has taken on the task of maintaining dialogue with extra-regional partners. These include dialogue processes with the European Union, China, Russia, India, South Korea, and Turkey. CELAC does not have the status of an international organization. It is a purely inter-governmental mechanism for political dialogue and consultation. It has no supranational competencies vis-à-vis its member countries. CELAC can adopt political declarations if there is a consensus among all member countries, but it does not have exclusive competencies or competences shared with the member countries. The creation of CELAC was not least in the interest of Mexico, because on a symbolic level, it revived the idea of a unified Latin America, which includes Mexico. For some years, Mexico had feared exclusion from the region, because with the founding of UNASUR, the idea of South America as a central reference area of regional cooperation seemed to prevail. The challenge of CELAC is to successfully establish a multilateral forum 
that permits the Latin American and Caribbean region to express itself with one voice, thereby strengthening its position in the international system based on its shared values, interests, and objectives. ${ }^{8}$

\subsection{Pacific Alliance}

The fourth newly established regional organization is the Pacific Alliance (PA) between Chile, Colombia, Mexico, and Peru. The four member countries have a number of similarities. These are the Latin American countries that rely most heavily on the market economy, private entrepreneurship, competition, innovation, and integration into the world economy. Their economies are highly deregulated and open to the world market due to low tariffs. All have signed a large number of bilateral free trade agreements with regional and extra-regional partners and are working hard to cooperate with countries in the Asia-Pacific region. The central objectives of the PA are: to strengthen open regionalism; to deepen economic integration between member countries through progressive liberalization of the circulation of goods, services, capital, and people; to harmonize existing rules and thus reduce transaction costs; to build a platform for political dialogue and political coordination; to enable joint projection towards the Asia-Pacific region; and to promote increased cooperation in science and technology.

In terms of its functional mechanisms, the PA does not differ from the other organizations. Here, too, the principle of consensus applies, important decisions being taken jointly by the presidents, even if a council of foreign ministers and other specialized ministers as well as working groups on trade and integration, services and capital, cooperation, migration, and institutional affairs prepare the decisions. The achievements of the PA include common platforms for export promotion, the establishment of a common stock exchange, elimination of more than $90 \%$ of intra-community tariffs, the mutual abolition of visa requirements and joint projects and programs in the field of scientific and technological cooperation. Critics regard the alliance above all as a successful marketing strategy and point out that intra-PA trade represents only a very small part of their foreign trade for all four member countries. On the part of some ALBA member countries, PA has been criticized as the Trojan horse of neoliberalism in Latin America and as an instrument of US hegemony that serves primarily to undermine progressive integration projects. ${ }^{9}$

8 For CELAC see Llenderrozas, Rojas Aravena, Serbin.

9 For the PA see García; Nolte, "The Pacific"; SELA, The Pacific. 


\section{Regionalism after the End of the 'Left Wave'}

Undoubtedly, regional cooperation in Latin America has been characterized by very dynamic developments since the beginning of the 21 st century. From a theoretical perspective, these developments were explained using concepts such as post-hegemonic or post-liberal regionalism. Many observers hoped that a more solidary form of regional cooperation could prevail in the long term. However, since 2015, Latin American regionalism has been characterized by stagnation in many areas. The end of the presidency of President Luiz Inácio Lula da Silva in Brazil (2003-2011), the death of Venezuelan president Hugo Chávez Frías in 2013, the change of power to liberal conservative governments in Argentina (2015) and Brazil (2016), and profound domestic crises in Brazil and Venezuela have affected intra-Latin American cooperation.

UNASUR celebrated its tenth anniversary in 2017, but has de facto been in standby since the beginning of the year. After the end of Secretary General Ernesto Samper's mandate at the end of January 2017, member countries have not been able to agree on a renewed mandate for the former Colombian president nor on a new candidate. The twelve thematic cooperation councils have hardly met in recent times. In addition to the institutional design of UNASUR (the requirement of unanimity), the changed political balance of power in the region has contributed to the stagnation of the organization. Even in times of Chávez and Lula, conflicting ideological positions within UNASUR existed. Unlike at that time, however, currently there seems to be little political will to discuss South America's problems and challenges in the context of UNASUR (Gómez and Vollenweider).

Unlike UNASUR, CELAC has never been an international organization but merely a network. On January 25, 2017, CELAC realized its fifth summit meeting in the Dominican Republic. Significantly, a number of presidents, including Argentinean president Mauricio Macri, Brazilian president Michel Temer, and Chilean president Michelle Bachelet, did not attend the discussions. As was customary at such meetings, a joint action plan has been signed, but CELAC is a long way from common positions on key challenges facing Latin America and the Caribbean, such as the question of how the region should behave towards the US government under Donald Trump. The original objective of coordinating common regional positions on important issues of hemispheric and international politics, and thus strengthening Latin America's and the Caribbean's actorness in the international system, remains a vision for the time being.

Both UNASUR and CELAC, which advocate cooperation across ideological and developmental borders, have become increasingly stagnant in recent years. 
On the other hand, ALBA and the PA, each representing very different strategies for incorporation into the international system ('21st century socialism' versus 'open regionalism'), were much more active in their own specific ways. ALBA continues with declarations for a continuity of efforts for Latin American unity 'succeeding Bolívar, San Martín, Martí, Fidel and Chávez, ${ }^{10}$ while the PA pursues its policy of small steps of pragmatic cooperation between the organization's member states. ${ }^{11}$

\section{Latin American Regionalism: Explanatory Factors}

Latin American regionalism is characterized by great institutional and organizational diversity. It should be noted that there are a number of other regional and sub-regional cooperation and integration mechanisms in addition to the institutions mentioned in this chapter. The competencies of the different institutions are often not clearly separated. There is a tendency to establish a new institution rather than undergo the hardships of overcoming the shortcomings of existing institutions. Over the decades, this has led to some regional organizations giving the impression of "living museums" that owe their survival more to the law of inertia than to the will of their member countries to use them as instruments of regional cooperation.

Despite large differences in their objectives, Latin American regional organizations as a whole are characterized by organizational weaknesses, low decision-making authority, and narrow scope for action. Therefore, regional organizations cannot play a pro-active role in deepening regional cooperation and integration. Latin American foreign policy continues to be characterized by the dominance of presidential diplomacy, leaving little room for supranational aspirations. In times of active and charismatic regional leadership by personalities such as Lula and Chávez in the first decade of the 21st century, this institutional weakness was less significant. All the more, however, after their resignation, a regional leadership vacuum has emerged, which points to how limited the real scope of action of regional organizations is in Latin America.

In addition, there is a low efficiency of regional rules and norms with regard to influencing the behavior of states and governments. Tolerance for noncompliance with multilateral agreements is high, and the tendency to non-transfer of rules agreed at (sub-)regional level into national legislation is widespread.

10 See the corresponding articles on the Internet platform <http://www.portalalba.org/>, as of $21 \mathrm{Feb} .2018$.

11 See <https://alianzapacifico.net/>, as of 9 July 2017. 
Another important factor, particularly with regard to Latin America's role in global forums, concerns the predominantly introspective nature of regionalism. A common positioning in relation to global issues only takes place in a very general way. This is essentially due to three key factors, which are discussed in more detail below: first, the divergent development strategies in place in the region; second, the concepts of sovereignty that dominate Latin America; and third, the specific characteristics of regionalization in Latin America.

\subsection{Divergent Development Strategies}

More than 35 years ago, Kenneth Coleman and Luis Quiros-Varela proposed a concept that established relationships between different types of development strategies and foreign policy strategies (Coleman and Quiros-Varela). Of course, the situation of Latin America and the world has changed fundamentally since then, and the development strategies presented by the authors at that time no longer correspond to the currently dominating types. Nevertheless, their fundamental considerations remain interesting. Coleman and Quiros-Varela distinguished between three development strategies, conventional, reformist, and revolutionary strategies, and discussed the foreign policy consequences of each strategy. While not being able to discuss this in detail here, it must be noted that every development strategy has consequences for the strategy of the international incorporation of a country and thus for its attitude towards regional cooperation and integration processes. In this respect, it can be hypothesized that a country will be all the more involved in a regional organization or a regional integration process, the more this organization and/or process corresponds to the respective development strategy. The central elements of a development strategy refer to the issue of domestic versus outward orientation; the preferred role of the state, the market, and private enterprises for economic development; the degree of regulation and opening of the economy to the world market; development priorities, and the role of foreign direct investment. A development strategy also reflects the way in which the relationship between national, regional, and global interests is conceived and perceived. Of course, such considerations have consequences for the respective strategy of international incorporation, the preferred external partners as well as possible concepts of the enemy.

Generally speaking, we can currently distinguish three divergent development strategies in Latin America: neoliberal, heterodox-reformist, and radical strategies. The consequences of these strategies for the factors mentioned in the preceding paragraph have led to the emergence of competing regional organizations such as ALBA and the PA, of which there is no overlap between their members. 
Different development strategies have also made it difficult for institutions such as UNASUR or CELAC, which have a very heterogeneous membership in terms of development strategy, to formulate common positions that go beyond very general wording and declarations of intent.

\subsection{Traditional Concepts of Sovereignty}

A second explanatory element for Latin America's difficulties in creating strong regional institutions and speaking with one voice to external actors refers to the concepts of sovereignty that dominate the region. Originally, the idea of sovereignty referred to an internal dimension of states. In medieval times, it served as a mechanism that ensured the king's authority over the feudal lords. With the signing of the Peace of Westphalia in 1648, sovereignty became a fundamental norm of international relations. States were considered equal among themselves; they should not be subject to supranational authority and, for their part, not intervene in the internal affairs of other states. In this sense, sovereignty meant autonomy and independence of states over any kind of external authority.

From a European perspective, in times of globalization and in the face of a multitude of international interactions and interdependencies, the concept of absolute sovereignty is an anachronism. Proponents of the idea of shared sovereignty argue for a partial transfer of national decision-making powers to supranational regional organizations. It is assumed that the resulting power of the supranational organization is greater than the sum of the national powers. Moreover, it is understood that shared sovereignty does not mean the end of national sovereignty, but ultimately serves to strengthen and stabilize it. ${ }^{12}$

While the experience of two world wars in Europe has strengthened the idea that restricting the absolute sovereignty of nation states is necessary to guarantee peace, the historical experience of Latin American countries is quite different. Even after independence from Spain and Portugal, most Latin American countries have experienced a recurring threat to their national sovereignty by external actors, notably European states (mainly in the 19th century) and the United States. While the limitation of national sovereignty in the framework of the European integration process was conceived as a tool to prevent new wars

12 Such ideas underlie the European integration process. However, even in the European Union, supranational processes and structures only exist in individual policy areas. In addition, the multiple crises of European integration in recent years have led to questions not only of the status quo and even of the continued existence of the Union, but also of its potential role model for integration processes in Latin America. 
in Europe, the basic motives of Latin American regionalism were and are different: they are particularly linked to the objectives of development and guarantee of autonomy and independence vis-à-vis extra-regional actors (Pastrana Buelvas; Pastrana Buelvas and Alegría).

\subsection{Specifics of Regionalization in Latin America}

As mentioned in the introduction, the term "regionalization" refers above all to transnational economic, political, social, or cultural interactions of non-state actors. Although the term "regionness" proposed by Hettne and Söderbaum has been rightly criticized (Schmitt-Egner 180), the authors' discussion on degrees of regionalization is useful to analyze the translocal interactions and densifications in a given region. Hettne and Söderbaum distinguish five stages of increasing regionalization, ranging from 'regional space' (a geographical unit delimited by more or less natural physical barriers and marked by ecological characteristics, but without translocal interactions of larger dimensions) to a hypothetical 'region-state' (461-68).

This is not the place to go into detail about the diverse translocal and transnational interactions of non-state actors in Latin America. Rather, I focus on the area of economic regionalization, as Latin American regionalism has long been heavily economic. The economic patterns of production and trade that have emerged during the centuries of colonialism have meant that the international incorporation of the economies of the independent Latin American nation states has been geared primarily towards extra-regional actors (first Europe, later the United States, today increasingly Asia). By contrast, economic and trade relations with neighboring countries always played a subordinate role. As Burges has shown, weak economic regionalization, the 'reality of trade,' places narrow limits on a primarily economic regionalism ("Bounded"). Of course, political elites can foster cross-border economic cooperation and integration, but non-state economic operators follow their actions with incentives and logics that are more geared to extra-regional partners than to their own region. The data published on a regular basis by CEPAL on intra-regional trade and intra-regional Foreign Direct Investment (FDI) are very telling. In 2016, only $22 \%$ of South American total exports went to South America. For Central America, the corresponding figure was $31 \%$, and for the Caribbean $29 \%$. The most extreme cases were countries such as Mexico (5.3\%), Chile (17.6\%), Peru (19.7\%), and Brazil (20.2\%), which handled only a very small proportion of their total exports within their own region (CEPAL 42-45). Outward FDI flows from Latin American and Caribbean countries, especially from Brazil, 
Mexico, Chile, and Colombia to other regional countries, have grown substantially in the 21st century, but they are still far less important than investments from the United States, Asia, and Europe (ECLAC 48-51). This explains why economic regionalism plays a subordinate role for many Latin American countries, while bilateral and multilateral cooperation with external partners is a high priority.

As we have seen, Latin American regionalism in the 21st century has increasingly distanced itself from purely economic concepts and embarked on new forms of regional cooperation and integration. This is understandable, as cross-border regionalization has increased in many areas and poses new challenges for nation-states. These include, for example, environmental issues, intra-regional migration processes, and security problems. The more these developments are perceived as common challenges by the governments of the region, the more likely it is that efforts will be made to develop regionalism in these areas.

\section{Conclusion}

After reviewing key milestones of Latin American regionalism since independence, this chapter first outlined the state of current regional cooperation and integration efforts, and then identified three key issues, divergent development strategies, traditional concepts of sovereignty, and a low degree of economic regionalization as causes of the weakness of Latin American regional organizations.

Regional cooperation in Latin America and the Caribbean has increased significantly in the past 25 years, leading to the emergence of a variety of new bilateral and multilateral cooperation and integration mechanisms. Although there has been no political integration in the strict sense, the present situation differs fundamentally from those times when intra-Latin American relations were characterized by reciprocal threat perceptions and rivalries. At that time, military governments and the doctrine of national security prevailed. Today, in spite of profound divergences and asymmetries, there is a fundamental willingness for regional cooperation in many policy areas. This is not to be forgotten despite all legitimate criticism of the present state of Latin American regionalism.

\section{References}

Altmann, Josette. "New Forms of Integration: ALBA Institutions and

Mechanisms." Inter-American Cooperation at a Crossroads, edited by Gordon Mace et al., Basingstoke, 2011, pp. 204-21. 
Barrios, Miguel Á. "Del unionismo hispanoamericano al integracionismo político latinoamericano." Integración latinoamericana y caribeña: política y economía, edited by José Briceño-Ruiz et al., Fondo de Cultura Económica, 2012, pp. 59-78.

Bianculli, Andrea C. "Latin America." The Oxford Handbook of Comparative Regionalism, edited by Tanja A. Börzel and Thomas Risse, Oxford University Press, 2016, pp. 154-77.

Birle, Peter. "Muchas voces, ninguna voz. Las dificultades de América Latina para convertirse en un verdadero actor internacional." Nueva Sociedad, no. 214, 2008, pp. 143-51.

Birle, Peter. "Zwischenstaatliche Konflikte in Südamerika vom 19. Jahrhundert bis heute: Ursachen, Lösungsansätze, Perspektiven." Lateinamerika im Aufbruch: Eine kritische Analyse, edited by Lothar Mark and Erich G. Fritz, Athena, 2009, pp. 123-36.

Birle, Peter. "Zwischen Integration und Fragmentierung: Regionale Zusammenarbeit in Lateinamerika." Lateinamerika im Wandel, edited by Peter Birle, Nomos, 2010, pp. 75-98.

Börzel, Tanja A., and Thomas Risse. "Introduction: Framework of the Handbook and Conceptual Clarifications." The Oxford Handbook of Comparative Regionalism, edited by Tanja A. Börzel and Thomas Risse, Oxford University Press, 2016, pp. 3-15.

Börzel, Tanja A., and Thomas Risse. "Three Cheers for Comparative Regionalism." The Oxford Handbook of Comparative Regionalism, edited by Tanja A. Börzel and Thomas Risse, Oxford University Press, 2016, pp. 621-47.

Briceño-Ruiz, José. "Autonomía y desarrollo en el pensamiento integracionista latinoamericano." Integración latinoamericana y caribeña: política y economía, edited by José Briceño-Ruiz et al., Fondo de Cultura Económica, 2012, pp. 27-58.

Briceño-Ruiz, José. "Ejes y modelos en la etapa actual de la integración económica regional en América Latina." Estudios Internacionales, no. 175, 2013, pp. 9-39.

Burges, Sean W. "Bounded by the Reality of Trade: Practical Limits to a South American Region." Cambridge Review of International Affairs, vol. 18, no. 3, 2005, pp. 437-54.

Burges, Sean W. "Consensual Hegemony: Theorizing Brazilian Foreign Policy after the Cold War." International Relations, vol. 22, no. 1, 2008, pp. 65-84.

Burr, Robert. "The Balance of Power in Nineteenth-Century South America: An Exploratory Essay." Latin America's International Relations and Their Domestic Consequences: War and Peace, Dependency and Autonomy, 
Integration and Disintegration, 1955, edited by Jorge I. Domínguez, Garland Publishing, 1994, pp. 1-24.

Capelato, Maria H. “O 'gigante brasileiro’ na América Latina: ser ou não ser latinoamericano." Viagem incompleta: A experiência brasileira (1500-2000): A grande transação, edited by Carlos Guilherme Mota, Editora Senac, 2000, pp. 285-316.

CEPAL/Comisión Económica para América Latina y el Caribe. Anuario Estadístico de América Latina y el Caribe, 2017. CEPAL, 2018.

Coleman, Kenneth M., and Luis Quiros-Varela. "Determinants of Latin American Foreign Policies: Bureaucratic Organizations and Development Strategies." Latin American Foreign Policy: Global and Regional Dimensions, edited by E. Ferris, Westview Press, 1981, pp. 39-59.

Comini, Nicolás, and Alejandro Frenkel. "Una Unasur de baja intensidad: Modelos en pugna y desaceleración del proceso de integración en América del Sur." Nueva Sociedad, no. 250, 2014, pp. 58-77.

Deciancio, Melisa. "El regionalismo latinoamericano en la agenda de la teoría de las Relaciones Internacionales." Iberoamericana. América Latina España - Portugal, vol. 16, no. 63, 2016, pp. 91-110.

Diamint, Rut. "Regionalismo y posicionamiento suramericano: UNASUR y ALBA." Revista CIDOB d'Afers Internacionals, no. 101, 2013, pp. 55-79.

ECLAC/Economic Commission for Latin America and the Caribbean. Foreign Direct Investment in Latin America and the Caribbean. CEPAL, 2017.

García, Jaime. “Alianza del Pacífico ¿Hacia dónde vamos?”. Agenda Internacional, vol. 20, no. 31, 2013, pp. 43-54.

Gardini, Gian Luca. "Proyectos de integración regional sudamericana: Hacia una teoría de convergencia regional." Relaciones Internacionales, no. 15, 2010, pp. 13-31.

Gómez, Ava, and Camila Vollenweider. “Había una vez UNASUR?? CELAG, 20 Jan. 2017, www.celag.org/habia-una-vez-unasur/.

Grabendorff, Wolf. "Interstate Conflict Behavior and Regional Potential for Conflict in Latin America." Journal of Interamerican Studies and World Affairs, vol. 24, no. 3, 1982, pp. 267-94.

Hettne, Björn, and Fredrik Söderbaum. “Theorising the Rise of Regionness." New Political Economy, vol. 5, no. 3, 2000, pp. 457-72.

Lafer, Celso. A identidade internacional do Brasil e a política externa brasileira: Passado, presente e futuro. Perspectiva, 2001.

Legler, Thomas. "Post-hegemonic Regionalism and Sovereignty in Latin America: Optimists, Skeptics, and an Emerging Research Agenda." Contexto Internacional, vol. 35, no. 2, 2013, pp. 325-52. 
Llenderrozas, Elsa. "Política exterior latinoamericana y la Comunidad de Estados Latinoamericanos y Caribeños.” Austral: Revista de Estratégia e Relações Internacionais, vol. 2, no. 4, 2013, pp. 183-205.

Mares, David R. "Regional Conflict Management in Latin America: Power Complemented by Diplomacy." Regional Orders: Building Security in a New World, edited by David Lake, Pennsylvania State University Press, 1997, pp. 195-218.

Mols, Manfred, editor. Integration und Kooperation in Lateinamerika. Schöningh, 1981.

Mols, Manfred, editor. Integration und Kooperation in zwei Kontinenten: Das Streben nach Einheit in Lateinamerika und in Südostasien. Franz Steiner Verlag, 1996.

Nolte, Detlef. Latin America's New Regional Architecture: A Cooperative or Segmented Regional Governance Complex? RSCAS Working Papers, 2014.

Nolte, Detlef. "The Pacific Alliance: Nation-Branding through Regional Organisations." GIGA Focus Latin America, no. 4, German Institute for Global and Area Studies, 2016.

Pastrana Buelvas, Eduardo. "Why Regionalism Has Failed in Latin America: Lack of Stateness as an Important Factor for Failure of Sovereignty Transfer in Integration Projects." Contexto Internacional, vol. 35, no. 2, 2013, pp. 443-69.

Pastrana Buelvas, Eduardo, and Rafael Castro Alegría. “The Long Road to State-Building in Latin America and Its Impact on Regionalization Processes." Papel Político, vol. 20, no. 2, 2015, pp. 1-26.

Portales, Carlos. “¿A dónde va el multilateralismo en las Américas? Proyectos superpuestos en un período de cambios globales." Pensamiento Propio, no. 39, 2014, pp. 35-74.

Riggirozzi, Pía. "Region, Regionness and Regionalism in Latin America: Towards a New Synthesis." New Political Economy, vol. 17, no. 4, 2012, pp. 421-43.

Rojas Aravena, Francisco. "La Celac y la integración latinoamericana y caribeña. Principales claves y desafíos." Nueva Sociedad, no. 240, 2012, pp. 16-27.

Sanahuja, José A. Post-Liberal Regionalism in South America: The Case of UNASUR. RSCAS Working Papers, 2012.

Sanahuja, José A. "Regionalismo e integración en América Latina: de la fractura Atlántico-Pacífico a los retos de una globalización en crisis." Pensamiento Propio, no. 44, 2017, pp. 29-75.

Schmitt-Egner, Peter. “The Concept of 'Region': Theoretical and Methodological Notes on Its Reconstruction." Journal of European Integration, vol. 24, no. 3, 2002, pp. 179-200. 
SELA/Sistema Económico Latinoamericano. El ALBA-TCP como mecanismo de cooperación de alcance regional. SELA, 2013.

SELA/Sistema Económico Latinoamericano. Estado actual y avances en la Arquitectura Institucional de la Integración de América Latina y el Caribe. SELA, 2013.

SELA/Sistema Económico Latinoamericano. The Pacific Alliance in Latin American and Caribbean Integration. SELA, 2013.

Serbin, Andrés. "Los nuevos regionalismos y la CELAC: los retos pendientes." Desafíos estratégicos del regionalismo contemporáneo: CELAC e Iberoamérica, edited by Adrián Bonilla Soria and Isabel Álvarez Echandi, FLACSO, 2014, pp. 47-78.

Söderbaum, Frederik. "Old, New, and Comparative Regionalism. The History and Scholarly Development of the Field." The Oxford Handbook of Comparative Regionalism, edited by Tanja A. Börzel and Thomas Risse, Oxford University Press, 2016, pp. 16-37.

Thiery, Peter. "Entwicklungsvorstellungen in Lateinamerika: Eine Neuauflage des CEPALISMO?" Entwicklungsdiskussion und Entwicklungspraxis in Lateinamerika, Südostasien und Indien, edited by Manfred Mols and Peter Birle, Lit Verlag, 1993, pp. 1-51.

Toro, Alfredo. "El ALBA como instrumento de 'soft balancing." Pensamiento Propio, no. 33, 2011, pp. 159-84.

Tussie, Diana. "Latin America: Contrasting Motivations for Regional Projects." Review of International Studies, vol. 35, 2009, supplement S1, pp. 169-88.

UNASUR. Tratado Constitutivo de la Unión de Naciones Suramericanas. SELA, 2008, www.sela.org/attach/258/EDOCS/SRed/2010/10/T0236000043490-Tratado_Constitutivo_de_la_Union_de_Naciones_Suramericanas_ (UNASUR)_-_Brasilia,_23_de_mayo_de_2008.pdf/.

Zimmerling, Ruth. “Die ursprüngliche Cepal-Doktrin.” Zeitschrift für Lateinamerika, no. 30-31, 1986, pp. 27-44. 



\title{
Gesa Mackenthun
}

\section{Storied Landscapes: Colonial and Transcultural Inscriptions of the Land}

\begin{abstract}
Globalization discourse tends to represent land as an abstract entity. But places are not just mathematically mapped and measured; they are also inscribed with human memories, which take the form of stories and are in this form passed on to future generations. This chapter will discuss such culturally inscribed places, located in the North American colonial contact zone of the Pacific Northwest. The chapter begins with a short discussion of Paul Lawrence Yuxweluptun's paintings articulating ongoing conflicts between Indian and non-Indian societies over land stewardship. It then centers on the cultural negotiation of geological events related to the mountain range called Cascadia which forms part of the Rocky Mountains and stretches from Northern California to British Columbia. Discussing the transcultural topological discourse relating to some parts of this geologically active region, the chapter shows the differences between a Western-rationalist approach to land and an indigenous approach that derives from regarding the land as sacred. The epistemic competition about the geological rimland of Cascadia is concurrent with a struggle over ownership of the lands in areas of the Pacific Northwest, most conspicuously defined in the Delgamuukw decision of the Canadian Supreme Court in 1997. Using examples from the Klamath and Modoc oral tradition relating to a 'prehistorical' cataclysmic event at today's Crater Lake, the chapter argues that indigenous oral traditions can indeed be very ancient and should be regarded as important sources for establishing tribal territorial rights, to be added to other existing sources of (historical) knowledge about the pre-colonial past in contemporary landrights court cases.
\end{abstract}

\section{Introduction}

Cascadia is a geologically active area. It is part of the global ring of fire, a volcanic circle surrounding the Pacific Ocean and extending from Java all the way to the southern tip of Chile (Fig. 1). The ring of fire includes Mt. St. Helens, which spectacularly erupted in 1981, as well as the volcanoes in Meso- and South America such as the recently erupted Volcán del Fuego in Guatemala or the currently inactive Chimborazo in Ecuador which had been the destination of the famous expeditions of Charles Marie de la Condamine and Pierre Bouguer in 1742 and Alexander von Humboldt, Aimé Bonpland, and Carlos Montúfar in 1802. 

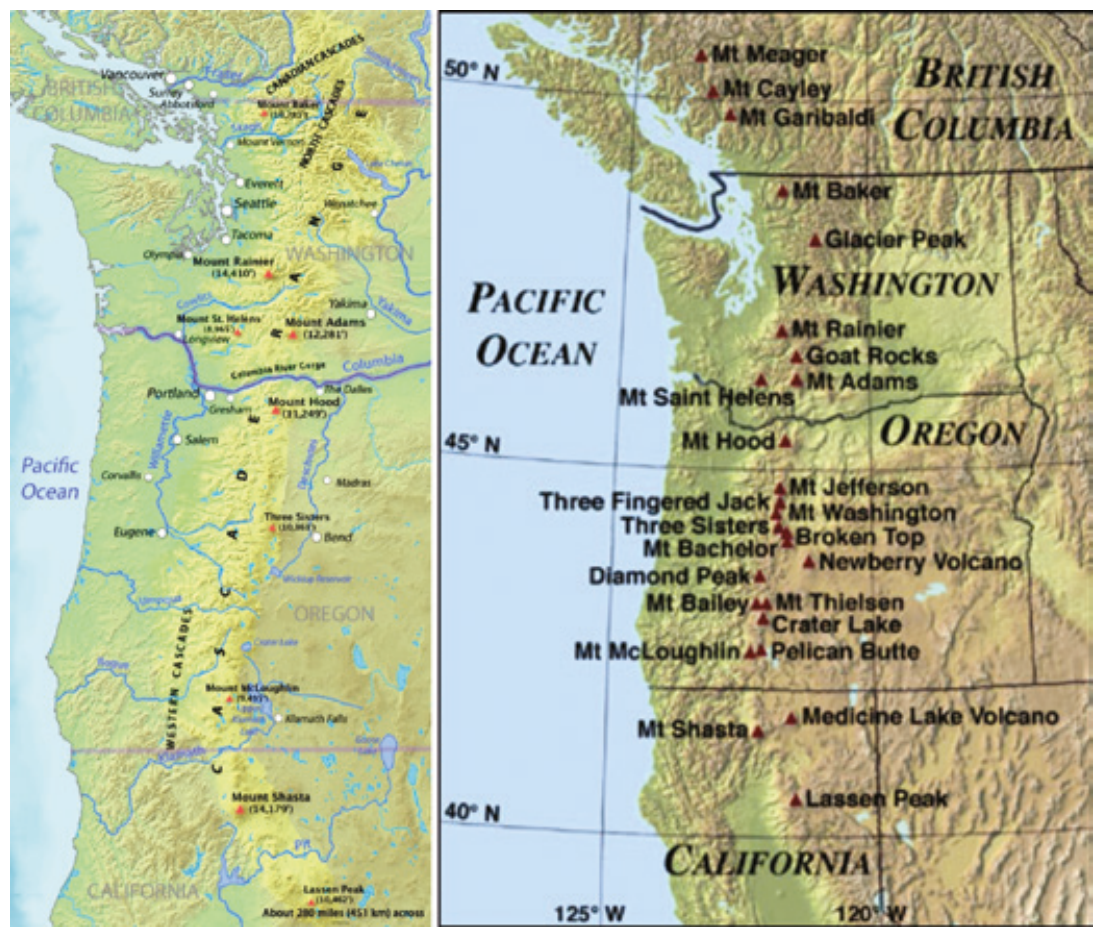

Fig. 1: Cascade Mountain Range. Source: Wikipedia

Part of a geological chain connecting Asia with the western coast of the Americas, the Cascadian Range is a "rimland"-first, in a cultural sense: as an area where people from many cultures have met and interacted for millennia before the arrival of Europeans and then for a bit more than 200 years since the beginnings of colonization, involving many different nations and tribes; and, second, in a geological sense, as it lies above one of the world's most active tectonic "rims" or fault lines, the Cascadia Subduction Zone (CSZ). This means that in this area people have for thousands of years been exposed to cataclysmic geological events such as earthquakes, tsunamis, and volcanic eruptions.

Such risks notwithstanding, Cascadia is also one of the first areas continuously settled by human beings coming across Beringia and Yukon before, 
during, and after the last glacial maximum. ${ }^{1}$ Some of their stories may have preserved glimpses of that deep past. ${ }^{2}$

In addition to these seismic challenges, Cascadia has also been subject to massive interventions into the natural environment-especially logging, the building of oil and gas pipelines, and a severe reduction of salmon due to overfishing. These intensive extractive activities continue to give rise to conflicts, particularly between industrial and environmental interests, with the indigenous population usually siding with the environmentalists. Three paintings by the Cowichan and Okanagan artist Paul Lawrence Yuxweluptun express these conflicts (Figs. 2-4).

The images show well-however ironically-the indigenous conviction that the land itself is part of a cosmic organism: the hills are covered with symbols

1 Recent finds date a human presence in Yukon to 22,000 BCE. Archaeological examination of the Bluefish Caves in Yukon suggests that the Beringia Standstill Hypothesis (which holds that migration into America proper was stopped for c. 10,000 years during the last glacial maximum) is no longer feasible. Before these recent finds, the discoveries made by the team of Thomas Dillehay in the 1980s had long established that humans lived in Monte Verde in Chile at least 18,500 years ago, having migrated there from north via Beringia and/or across the Pacific Ocean (see Hogenboom).

2 A 2000 issue of American Antiquity features an interesting querelle about the usefulness of oral traditions as an additional archive to that of archaeology. Roger Echo-Hawk speculates that North American indigenous oral traditions about underground worlds and dark regions may contain, if in a "distorted" way, earliest memories of a "Pleistocene worldscape" that those ancestors crossed on their way to America. Narratives of "a land of lingering darkness as a place of origin became preserved as an underworld" (276-77). Other scholars, most notably Ronald Mason, express massive doubts about the mnemonic capacity of oral traditions to reach that far back. Unfortunately, Mason's approach is tainted by a weak understanding of the complexity of mythological texts (whose absence of chronology was proof of an absence of evidence for an earlier scholarship, to which Mason still seems to be attached). Increasingly drifting into a polemic style, Mason spells out the real intention for examining, and denying, the potential of native oral traditions when he writes that "[o]n any grounds amenable to logical argument and empirical testing, Native Americans are descendants of ancient immigrants and did not originate in the New World, however much their traditional histories attest the opposite ..." (262; emphasis added). Grammatically, the claim is wrong, as present-day Native Americans do indeed originate in the Americas, as did their ancestors who first welcomed European colonizers on their beaches and in their homes. It's the "ancient immigrants" who, being immigrants, did not "originate in the Americas." Neither did the less ancient European immigrants to the Americas or indeed the ancient immigrants to Europe (from Africa, the cradle of humanity). This logical slip indicates that the discussion about the ancient peopling of the Americas is an ideologically loaded issue that should be subjected to analysis sensible to the mechanisms of the coloniality of knowledge (Mignolo; Quijano). 


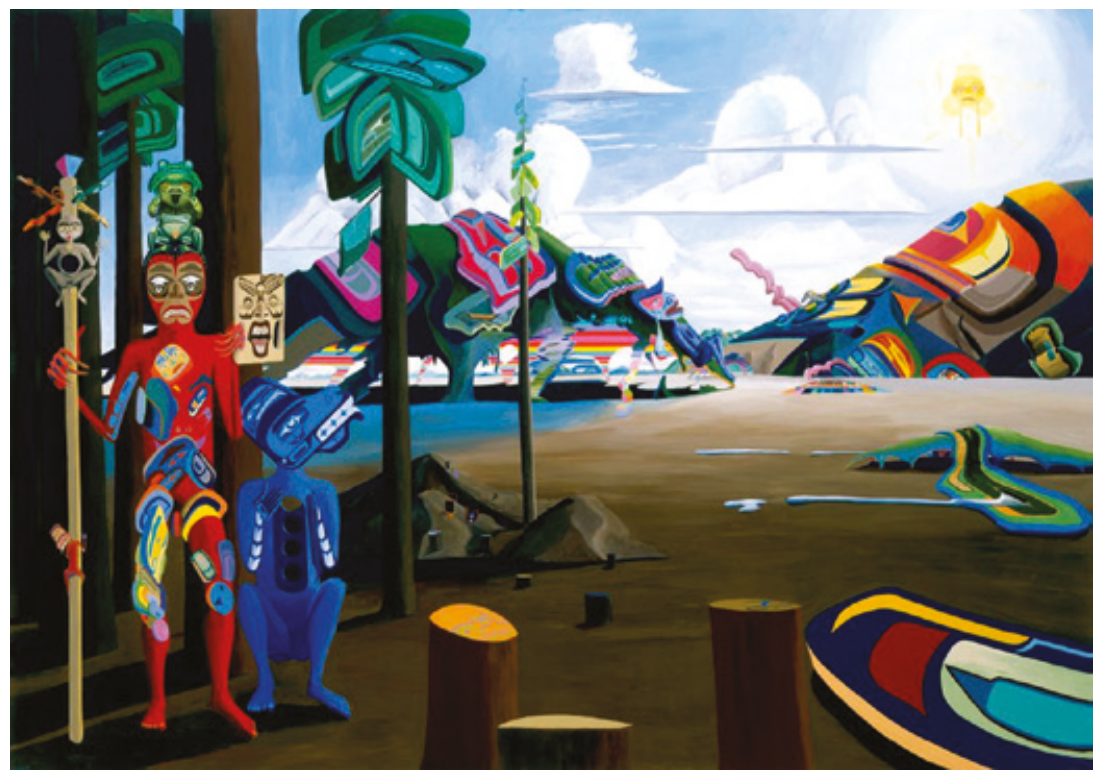

Fig. 2: Lawrence Paul Yuxweluptun, "Scorched Earth: Clear-Cut Logging on Native Sovereign Land" (1991). National Gallery of Canada, Ottawa. Source: Duffek/Willard.

typical of the expressive mode of Pacific Northwest culture. "Scorched Earth" (Fig. 2) shows the effects of clearcutting of the Pacific Coast cedar trees whose few remaining branches observe the sorrow inflicted on the landscape which is eroding and dissolving in tears. Even the sun is crying, while the image which the red figure holds in his hands might be seen as an indigenous remake of Munch's "Der Schrei" ("The Scream"). "An Indian Game" (Fig. 3) shows one of Yuxweluptun's typical 'machine men' dancing to the game of the white man juggling legal texts-among them Diane Engelstad and John Bird's essay collection Nation to Nation: Aboriginal Sovereignty and the Future of Canada (1992) that discusses the effects of colonial law on the lives of First Nations people and the difficult negotiations of obtaining indigenous participation in land stewardship procedures. The dancing native onlooker may suggest a critique of the inaction or even occasional complicity with such policy on the part of official tribal representatives. The most conspicuous element is the 'culturalization' of the trees, hills, and even clouds themselves, all of which bear similar mask-like faces as the indigenous 'machine man' (see Fig. 4). The land is covered with cultural meaning; it is inscribed with significance. Unlike Western landscape 


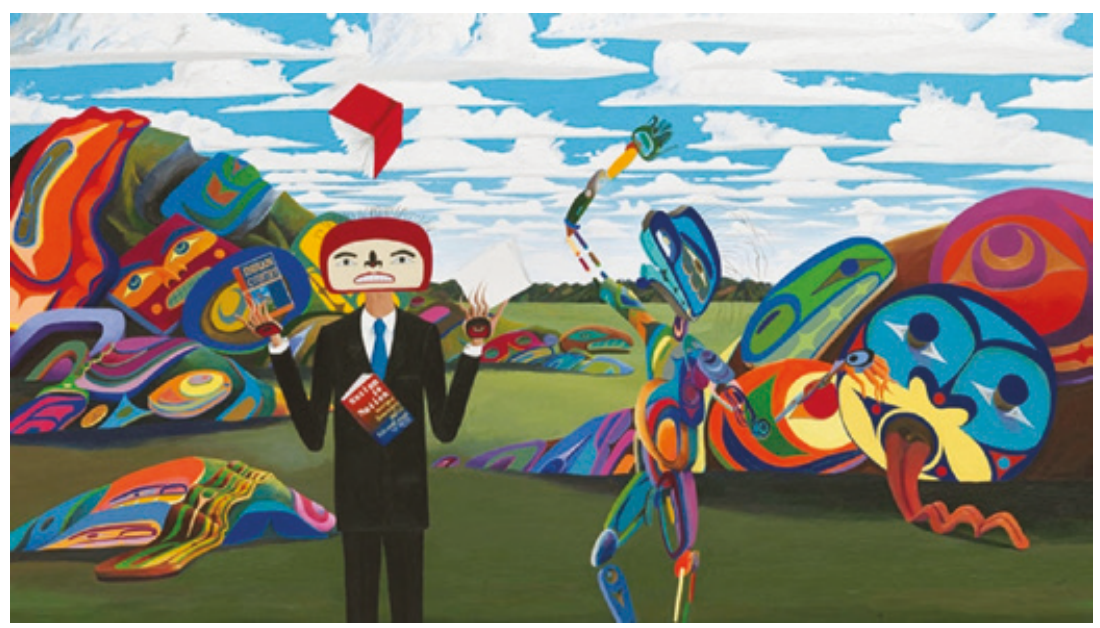

Fig. 3: "An Indian Game (Juggling Books)" (1996). Private Collection Michael Audain. Source: Duffek/Willard.

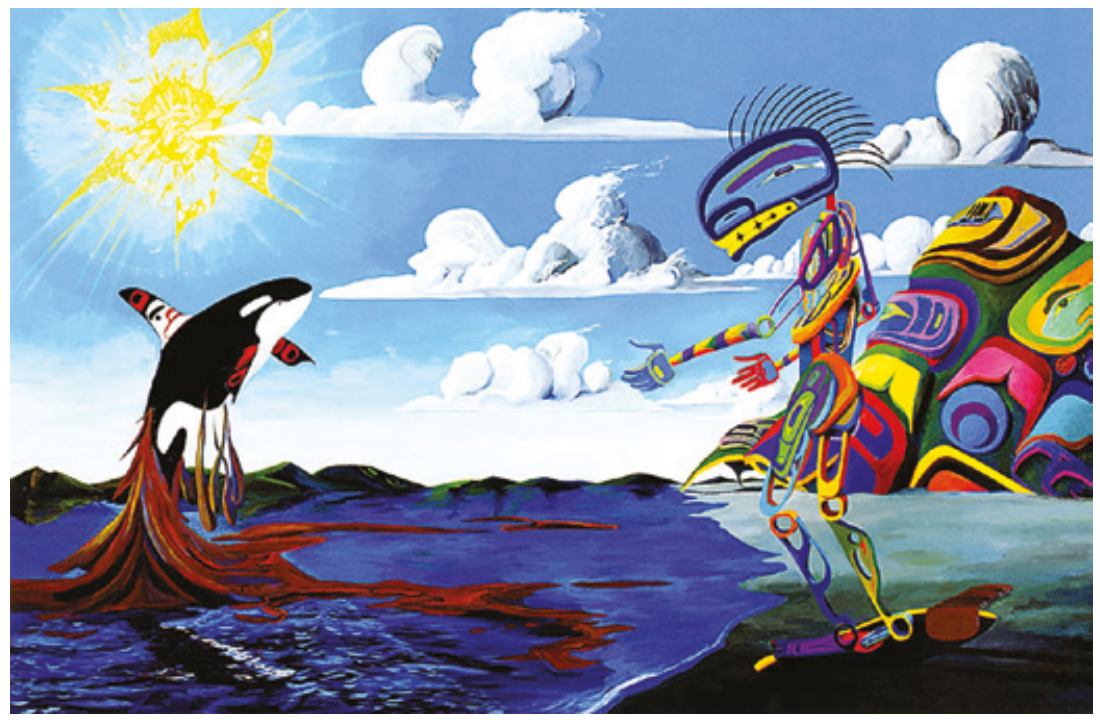

Fig. 4: "Killer Whale Has a Vision and Comes to Talk to Me about Proximological Encroachments of Civilizations in the Oceans" (2010). Private Collection. Source: Duffek/Willard. 
painting, which usually looks at the land from a distance, Yuxweluptun's work makes us look closely at the land itself, forcing us to behold the violent effects of stolen ("unceded") territories and modern resource extraction (Lippard 91). Yuxweluptun's paintings, as Lucy Lippard notes, differ from the Euro-American style of landscape painting in that they emerge "in the deepest sense from the land, from the mountains, sky, rivers, forests, and seas of the Northwest." They are "passionate but never sentimental." Glimpses of the past beauty of the land are mixed with stark representations of destruction: "polluted rivers, denuded forests, trash-strewn fields" (91). The land is retching and vomiting in the presence of clearcutting, pipeline leaks, contaminated oceans, and the legal tricks of businessmen. Above all, however, Yuxweluptun's countryside is a 'storied' and living countryside, while his human figures look like robots that have lost, or are about to lose, touch with the natural environment. The storied landscapes are part of a political and legal conflict about ownership and stewardship of the land.

The inscription of the landscape with cultural presences is not just an aesthetic feature; it is also a way of claiming that land. As Edward Chamberlin titled his 2003 book, If This Is Your Land, Where Are Your Stories?, stories express an affective and epistemic relationship to the land that is equivalent to owning that land. Chamberlin takes this sentence from a Gitskan (Tsimshian) elder of northwestern British Columbia who used this question in response to a government official offering to buy the tribe's land (1). The anecdote suggests that the state of 'owning' a place involves more than a commercial transaction; that it crucially depends on collective and deep historical knowledge of that place.

In the remaining part of this chapter, I would like to offer a glimpse of the significance of topological stories in a colonial contact zone in North Americathe geological and cultural faultline of the Pacific Northwest. In doing so, I hope to add to discussions central to this volume-about the various spatial constructions of America in a transcultural setting that inevitably produced competing and conflicting narratives of spatialization. In talking about geological and cultural fault zones and rimlands, then, the chapter also seeks to reflect on the theoretical and political implications of such constructions. My first example will deal with a cataclysmic event that is variously 'storied' by indigenous and Euro-American historical agents. I will then give a few examples of how oral tradition is being used as a guarantor of continuous habitation (uninterrupted residence) in legal cases about land. The special case I will use is the 1997 Canadian Supreme Court decision in the case Delgamuukw v. British Columbia which gives particular attention to the use of oral traditions in land litigation cases. 


\section{II}

Between 6,500 and 7,000 years ago, a gigantic volcanic eruption shook the Cascadian range and turned one of the highest mountains there-now called Mount Mazama-into a huge crater, today's Crater Lake in Oregon. It is the deepest lake in the United States. There are various narrative versions of the outbreak, two of which deserve mention here: the first story was told by Klamath Indians in the nineteenth century. It was allegedly first collected in 1865 by a nineteen-year-old soldier, William M. Colvig, stationed at Fort Klamath, from the Klamath Chief Lalek, and later included in a collection of stories by the schoolteacher Ella Clark, published in 1953. Colvig did speak the languages of the local tribes and was familiar with their culture. He tries to find an explanation why the area around Crater Lake is tabooed among the Klamath. He then hears the story about a battle between two superhuman competitors for the favor of a human woman. These are Llao, the "Chief of the Below World" who inhabited the mountain now referred to as Mount Mazama, and Skell, the "Chief of the Above World" who, so the story goes, inhabited Mount Shasta to the south. Both gigantic figures are standing on their respective mountains engaged in throwing stones at one another. The battle culminates:

Mountains shook and crumbled. Red-hot rocks as large as the hills hurled through the skies. Burning ashes fell like rain. The Chief of the Below World spewed fire from his mouth. Like an ocean of flame it devoured the forests on the mountains and in the valleys. On and on the Curse of Fire swept until it reached the homes of the people. Fleeing in terror before it, the people found refuge in the waters of Klamath Lake. (Clark 54)

In this extreme crisis, two medicine men sacrifice themselves to rescue the people and walk into the mouth of the volcano, the "entrance of the Below World" (55). The "Chief of the Below World was driven into his home, and the top of the mountain fell upon him. When the morning sun rose, the high mountain was gone" (55). In this version, easily identifiable as the result of transculturation, we have a familiar way of rendering a cataclysmic event as a gendered competition between two supernatural powers, heaven and hell-a demonic ménage à trois. The story features the sacred leaders as heroes who sacrifice themselves to save their people. Its twofold function is to explain a geological event and to provide social authority to the caste of sacred men. Yet, as I will argue at length in a forthcoming publication, this version is a diluted rendering of a number of oral traditions collected from Klamath and Modoc storytellers by Albert Gatschet and Jeremiah Curtin earlier in the 1870s and 1880s and giving a less 'westernized' account of a catastrophic battle that happened at the same place. Because of these events, recorded for thousands of years, the place now called Crater Lake is demonstrably one of the most sacred places in the Pacific Northwest. 
The second story about the same place-Crater Lake in Oregon alias Mount Mazama-was written almost concurrently with the publication of the first story. It belongs to a very different rhetorical register. It is the first full-length geological account of the eruption and collapse of Mount Mazama and was provided by the Berkeley geologist Howel Williams. His study The Ancient Volcanoes of Oregon appeared in 1948 and continues the work of the first geological expedition ever made to Crater Lake under the leadership of Joseph Silas Diller in 1897. Williams mentions no oral tradition or archaeological finds but makes repeated reference to a human presence during the outbreak. He assumes that the "Indians who occupied Oregon for thousands of years before the arrival of the white man must have witnessed countless eruptions," and he speaks of a "cataclysm seen from afar by the early Indians. They had long been familiar with the majestic ice-capped cone, for it rose to a height of 12,000 feet, a mile above its present ruins" (45). His scientific report makes use of a host of literary devices. This was not unusual at that time when narrative history was an accepted style in historiographical writing. Two of these stylistic elements are ekphrasis and metaphor: the animals, he writes, were "[a]larmed by the quakes" and fled while "the Indians, aware of the menace, withdrew to a safer distance":

Finally, a plume of white vapor rose from the summit. Within a few hours, it changed to a towering column, becoming darker and more ominous as the content of ash increased. At first, the eruptions were mild, and the fragments falling from the cloud were no larger than particles of sand. But day after day, the intensity of the explosions mounted. Huge cauliflower clouds rose higher into the sky, to be drifted eastward by the wind. Night after night, the clouds were more brightly lit by incandescent ejecta describing fiery arcs in their flight. The roars from the crater grew louder, and frenzied streaks of lightning multiplied in number. Many of the fragments were not as large as a clenched fist, and showers of fine ash began to fall hundreds of miles away, on the plateau east and northeast of the volcano. In lands thousands of miles distant, men marvelled at the brilliant colors in the sky as the rays of the setting and rising sun shone through the dustladen air. (46; emphasis added)

The text continues in this vein. Williams recreates the event for his readers, for whom moving images of volcanic eruptions were still unknown but whose memories were probably ripe with images of the nuclear bombs of Hiroshima and Nagasaki, as well as the contemporaneous nuclear tests in the Pacific with their famously featured "mushroom" clouds (initially referred to as "cauliflower clouds"). There is an interesting dialogue between the visual coverage of the man-made

3 The metaphor was used as part of the official terminology for the Operation Crossroads (Baker) Test of 1946 (see https://en.wikipedia.org/wiki/Mushroom_cloud and Weisgall 222). 
nuclear disasters of the twentieth century and the reconstruction of the ancient natural cataclysm. What connects them is the language of the sublime and the shape of the clouds. ${ }^{4}$ Williams's text is written in the style of an eyewitness account whose graphic detail differs only slightly from the details found in the KlamathColvig-Clark story. It is accompanied by-and produced in tandem with-two 'illustrations' of the outbreak that took place 6,600 years ago according to his reckoning (45). The images, unlike the drawings and photos included elsewhere in Williams's study, are reproductions of two paintings by a contemporary artist, Paul Rockwood, producing the scene according to Williams' instructions (63). ${ }^{5}$

Rendered in the exquisite style of American landscape painting, Rockwood's paintings aesthetically integrate the 'prehistoric' event into the narrative of the American West as a wilderness ruled by primeval geological forces. It is a form of domesticating that event into the cultural archive of the United States. The ancient event is integrated into a spatial aesthetic familiar to the reader from the famous landscape paintings of Thomas Cole, Albert Bierstadt, and Thomas Moran whose landscapes are usually devoid of human presence and thus available for the recipient's full visual 'possession' and imaginative immersion. This aestheticizing gesture, however, contrasts with Williams' verbal description of the outbreak and his conspicuous evocation of humans having observed the event. We know that this was indeed the case: remains of human occupation were discovered underneath the ashes of the Mazama eruption in nearby rock caves at Fort Rock, Oregon (Cressman). The abovementioned Klamath story recorded by Colvig and Clark thus confirms an archaeological knowledge that came into existence in the 1930s with Cressman's excavations, with the important additional information that the event is still remembered by the descendants of the ancient inhabitants, meaning that there exists a cultural continuity between those who experienced the eruption and the collapse of the volcano and the present-day indigenous inhabitants. ${ }^{6}$ The story of Mount Mazama-called "Gi-was" by the Klamath and Modoc Indians-is and has been a central element of their oral

$4 \quad$... a "Plinian" one in the case of the reconstructed Mazama event.

5 The spectacular paintings of Paul Rockwood, especially "Mt. Mazama Just before the Destruction of Its Summit" and "Mt. Mazama Just after the Destruction of Its Summit," both from 1940, can be seen on this website: https://www.nps.gov/media/photo/gallery.htm?id=F2699A00-155D-4519-3EBD76C2749BD03C (last accessed 5 September, 2017). The little word "just" signals an immediacy of observation and a scientific exactitude completely out of sync with the fact that even in the Old World, no human record exists that documents such an ancient event.

6 For a contemporary version, see the narrative by Barbara Alatorre. 
tradition; the lake and the surrounding mountains, which have been a national park since 1902, are to them a "most sacred place" (Deur 51-88). If we apply Vine Deloria Jr.s distinction between four kinds of sacred places-sites of memorable historical events; historically conspicuous sites since imbued with spiritual meaning; sites of mythical relevance and spiritual revelation; and sites of continued revelation (272-78) - Gi-was is a sacred place in the second and third sense, not only owing to human occupancy (in pre-colonial times it was actually exempted from normal human presence) but because various tribes have retained the knowledge of these terrifying events in their stories (274).

The two narrative traditions of the ancient eruption are not treated coevally in the historical archive, due to the fact that one of them is a scientific narrative and the other 'only' a set of stories by some old Native Americans. Yet the precise place to which the story relates-into which it is inscribed, to which it is associatively attached-may serve to verify the antiquity of the collective memory. Although the versions of the myth related by Colvig and Clark have been influenced by the cultural encounter, ${ }^{7}$ there is abundant evidence of a mythical memory of a cataclysmic event related to that particular place-Gi-was-collected in the first few years of colonial encounter and before any geological account of the eruption and collapse of Mount Mazama came into circulation. As scholars of oral traditions have found (Jan Vansina and others), it is extremely rare that a story tradition can continue to carry specific historical content over such a long period of time. Over the passage of several thousand years the historical kernel will be successively rearticulated and translated into a metaphorical and mythical language-as we know it from the long-term narrativization of Biblical and classical historical events. ${ }^{8}$ As Vansina contends, the longevity of an oral tradition is in part determined by the intensity of the event (175). The eruption that took place at Gi-was in c. 6,600 BCE must have cost the lives of many people and significantly changed the landscape, causing harvest failures and starvation. Its impact can be compared to that of the main disasters of Mediterranean antiquity, from the subduction of Atlantis and Sodom and Gomorrah (whose date and

7 Colvig wrote down the story about sixty years after he had allegedly first heard it. Both his original version of 1921 and Clark's abbreviated version of it in Indian Legends are influenced by their knowledge of the geological reconstructions of the collapse of the mountain that began to appear since 1897 .

8 These multi-layered texts are extremely difficult to unravel. I have tried to do so with the Klamath and Modoc traditions in a chapter of my upcoming book on the constructions of American antiquity. 
place are uncertain) all the way to the eruption of Vesuvius destroying Pompeii and Herculaneum as recently as $79 \mathrm{AD}$.

While stories from various tribes outside of the Pacific Northwest may contain vague memories of Pleistocene migrations (as Roger Echo-Hawk suggests), tribal legends in the Pacific Northwest often contain very precise spatial references. Only in correlating the mythical stories with the geological reconstruction of the events can the antiquity of the stories be ascertained. Conversely, the contents of the story may contain information about the emotional intensity of the cataclysm that no scientific account is able to record.

In the Pacific Northwest such a correlation is indeed possible. There are various reasons for this. First, some of the tribes who have kept these traditions, especially the Klamath, have been less exposed to massive dispossession and forced dislocation than other tribes; though the Modoc were indeed deported to the Indian Territory after the Modoc War, the translator Jeremiah Curtin was able to obtain extremely rich mythical-topological information from them. Albert Gatschet, another early linguist recording the Klamath stories, in fact writes that they were "autochtonous" to that place and had no memories of historical migrations (Gatschet xli). It is interesting in this context that the Klamath were among those tribes subjected to a brutal termination policy in the twentieth century: one of the most vicious attempts to destroy their cultural and social existence. They are still struggling to regain their former political, cultural, and territorial independence.

Second, the stories are tied to the same spatial features which are still visible; this activates the human faculty of tying cultural understandings to specific places. Émile Durkheim, Georg Simmel, and more recent theorists of cultural topologies have theorized this affective aspect of human place-making (see Shields 81-88). Displaced tribes like the Cherokee may still remember the old stories of the Smoky Mountains in their former homeland; they may even attach those stories to new spatial features that remind them of the old land (see Oakley). ${ }^{9}$ But generally the retention of the tie between physical landmarks and the stories originally inspired by them seems to be a guarantee of longevity (and of precision).

Finally, the European collectors of the stories relating to the Pacific Northwest, featuring such linguistically sensitive experts as Franz Boas, Albert Gatschet, Jeremiah Curtin, and the schoolteacher Ella Clark, were particularly well

9 European migrants and immigrants do the same, naming new villages after their old homes both regionally and transcontinentally. 
equipped to produce high quality records-perhaps more so than folklorists in other regions of North America.

\section{III}

In the past twenty years, various scholars have argued in favor of adding indigenous oral traditions to the other existing sources of knowledge about the precolonial past. Unsurprisingly, they reject the term 'prehistory' to refer to that period (Schmidt and Mrozowski). After having deconstructed the absolute truth claims of historiographical master narratives and after having seen the cracks in the fissures of many texts laying claim to scientific objectivity (see Williams's metaphorical overkill above), this may be the time to take indigenous oral traditions more seriously as historical evidence answering to the specific rules of the oral medium. The sociologist Julie Cruikshank, for example, has convincingly shown how the spatial memories of the indigenous inhabitants of the Yukon Territory cohere with scientific reconstructions of glacier movements, landslides and the like. Cruikshank treats all reports about geological events, whether written down or passed on orally, whether cultural or scientific, as collective memory narratives. Similarly, Ruth Ludwin and Coll Thrush triangulate the science of geology and indigenous oral traditions, rejecting the notion that 'science' and 'stories' form two separate and mutually exclusive archives but rather viewing them as two different ways of coming to terms with a very mobile landscape:

As the peoples of Cascadia struggled over millennia to come to terms with the geological realities of their homelands, they developed interpretations of seismic events that simultaneously reflected and shaped their lived experiences of place. Earthquakes and tsunamis were central components or relations between human beings and the other, nonhuman beings who inhabited the coastal regions. [...] earthquakes and tsunamis were understood to be moral events reflective of relationships between and among human people and the other residents of Cascadia. (6)

Following Ludwin and Thrush we can contend that all stories, whether scientific or not, are hybrid products of specific cultural constellations. They are hybrid, first, in themselves (their semantic reference is always to the real world and to a community's symbolic repertoire), and second, they are hybridized by the colonial epistemic encounter, being the result of cross-cultural exchange and transculturation. Oral traditions, then, require to be seriously investigated as a valuable cultural archive, not as alternatives or supplements to scientific accounts but as different narrativizations of an ever-changing earth. Though not technically equivalent to scientific reports because they are subject to different generic and mimetic rules and mnemonic processes, orally transmitted 
indigenous traditions offer us another geo-epistemological access to the world of the past and the present.

As Ludwin and Thrush also remind us, geology itself is in part the product of colonial settings, having "crystallized," as they write,

as a discipline in tandem with Europe's domination of large swaths of the world, it was shaped by those encounters; [...] European "discoveries" around the world led intellectuals, including mineralogists and other natural historians, to understand their own homelands in new ways, which in turn shaped how explorers, colonists, and others saw the "new" worlds. (8)

As a science of space invented during the period of European expansion, geology was "central to the process in that it offered a methodology to fuel the planet's industrial and economic transformation, but it also transformed historical narratives about the earth and its peoples" (8). They suggest that the geological surveying of colonized territories was not only concurrent with the territorial dispossession of native tribes but also, as other sciences, complicit with the "denigration, dismissal, and dismantling" of indigenous "systems of knowledge" (8). Needless to say, most of these conflicts centered on the ownership of the land-which is why displays of indigenous knowledge of land use and resource management form an important part of establishing tribal territorial rights in colonial courts today. And which is why indigenous oral traditions have been belittled as mere fairy tales for much too long. A colonial society has no interest in preserving the topological knowledge of the people it dispossesses.

\section{IV}

Collective topological memories, besides revealing information about how indigenous people experienced and reacted to cataclysmic events, have at times served as evidence of continuous residence and "cultural affiliation" in land rights cases (according to the Native American Graves Protection and Repatriation Act/NAGPRA of 1990). Here a great difference opens up between the way the US Supreme Court has treated conflicts over land ownership and stewardship and the more recent policy of the Canadian Supreme Court. In both cases, the rulings reflect discursive conflicts about the meaning of land, ownership, and narrative knowledge. In the 1980s, in a case known as Lyng v. Northwest Indian Cemetery Protective Association (US Supreme Court), the US Supreme Court foiled an attempt of two California courts to protect a wilderness environment sacred to the Yurok, Karok, and Tolowa tribes from destruction by a logging company. The tribes had invoked the free exercise (of religion) clause of the First Amendment as well as the American Indian Religious Freedom Act in their attempt to save 
the High Country in the Siskiyou Mountains in Northern California (Six Rivers National Forest) from serious deforestation. The claimants asserted that their ancestors had inhabited that area for millennia. They were joined by various environmentalist groups as well as two agencies of the state of California (W. Echo-Hawk 339). ${ }^{10}$ The lawsuit was filed against the US Forest Service which was planning to build a logging road through the mountains and to exploit the area for its timber. What's remarkable about the Lyng case is that two California courts ruled in favor of the plaintiffs-prohibiting the building of the road and the cutting down of the forest. The case was only overturned by the US Supreme Court. The records of the first trial, at the California federal district court, document impressive scenes of transcultural communication, as Walter Echo-Hawk shows (325-56). Judge Stanley Weigel, though not known as an environmentalist or lover of Indians, treated the elders who testified in court with utmost respect and allowed himself to come under the impact of the elders' stories about the spiritual significance of the Siskiyou Wilderness. Apparently he had a special rapport with an old medicine woman, Lowana Brantner (W. Echo-Hawk 341). Weigel handed down the landmark decision that regardless of its "unorthodox character," the tribal religious beliefs of the Yurok, Karok, Hoopa, and Tolowa were to be regarded as being under full protection by the Constitution (342). His ruling testifies to his (temporary) affective immersion into the spiritual universe of the Native Americans, as it had been explained to him in court.

The ruling in favor of the preservation of the sacred area was affirmed by the Ninth Circuit Court of Appeals in 1986. However, in 1988 the US Supreme Court turned down the motion with a majority of 5:3, on spurious grounds. It allowed the construction of the road ${ }^{11}$ through the ancestral sacred territory and denied applicability of the First Amendment to sacred sites. It simply refused to accept the cultural specificity of Native American religious practice. It likewise ignored any coevalness between the High Country and sacred sites existing and protected in Judeo-Christian religious cultures. Part of the Supreme Court's rejection of the priority of native spiritual rights over commercial interests is based on an analogy between the spiritual rights of the California tribes and another case involving the religious rights of a Native American: that of a twoyear-old girl whose parents refused the issuing of a social security number for her (US Supreme Court). ${ }^{12}$ The Supreme Court majority argues that "[the]

10 Thomas Pynchon obliquely includes the conflict in his novel Vineland (1990; see the original cover).

11 (Gasquet and Orleans = G-O Road)

12 The analogous case used is Bowen v. Roy (1986). 
building of a road or the harvesting of timber on publicly owned land cannot meaningfully be distinguished from the use of a Social Security number" in the way it impinges on the exercise of religious rights.

The comparison fails on various accounts-e.g. by equating individual religious rights with the collective religious rights of whole tribes, ${ }^{13}$ and by ignoring the topographical component of the tribes' religious exercise. The analogy is also reminiscent of the legal and cultural discourse of infantilizing Indians. The tribes' complaint-that the logging scheme would virtually destroy their religion-is defined away with the help of legal fiction and hair-splitting sophistry. The majority also offered a severely limited interpretation of the free religious exercise clause of the US Constitution. It argues that unless the government punishes a person for exercising his/her religion or forces him/her to violate his/her religion, one cannot speak of an infringement upon religious rights. Walter Echo-Hawk, echoing the comment of the dissenting Judge Brennan, concludes: "Under this restrictive vision of religious liberty, government can destroy an entire religion with constitutional impunity" (347).

The court's fear was that the granting of religious freedom in this land-related case might open the floodgates to future land claims by Indian tribes-that Indian entrepreneurs might acquire "de facto beneficial ownership of some rather spacious tracts of public property," that it might indeed eventually "divest the Government of its right to use what is, after all, its land" (O'Connor, after W. Echo-Hawk 348).

The question is precisely whose land it is. This is the question underlying many of the discussions about the antiquity of the indigenous presence in America and their ancestral rights derived from it: the unvoiced knowledge that the process of territorial dispossession was, and continues to be, disturbingly incompatible with Western moral standards.

In his passionate dissenting opinion, Justice William Brennan readily identifies the real motivation for turning down the case: "In the final analysis, the Court's refusal to recognize the constitutional dimension of respondents' injuries stems from its concern that acceptance of respondents' claim could potentially strip the Government of its ability to manage and use vast tracts of federal property" (US Supreme Court). In response to this fear, he points out the diligence with which earlier courts had made sure to ascertain the spiritual centrality of the Siskiyou wilderness for the involved tribes, praising their good ethnographic work in the California courts. ${ }^{14}$ The case, according to Brennan, "represents yet another

13 But the Constitution guarantees individual rights, not collective ones.

14 Such work is actually demanded by the AIRFA. 
stress point in the longstanding conflict between two disparate cultures-the dominant Western culture, which views land in terms of ownership and use, and that of Native Americans, in which concepts of private property are not only alien, but contrary to a belief system that holds land sacred." He sarcastically concludes, faintly echoing a famous phrase of Red Cloud, that with the Court's decision to value the construction of a marginally important logging road on a higher level than the preservation of the Native Americans' spiritual rights, those rights will amount to "nothing more than the right to believe that their religion will be destroyed" (US Supreme Court). ${ }^{15}$

Nine years later, in 1997, the Canadian Supreme Court formulated a radically different attitude toward indigenous traditional land rights in the so-called Delgamuukw case (Delgamuukw is the indigenous name of one of the claimants, Earl Muldon). In 1984, while the Lyng case was still pending, more than 100 Gitxsan (Gitskan or Tsimshian) and Wet'suwet'en Hereditary Chiefs in the province of British Columbia had filed a complaint against the Province of British Columbia in reaction to clear-cut logging on their traditional land. They claimed unextinguished Aboriginal title to the land (there had been no treaties) and asserted that their claims constituted a burden upon the land title of the Crown. In 1991, Judge McEachern at the B.C. Supreme Court decided in favor of the B.C. government. He rejected the oral traditions given as court testimony by the elders in order to establish their tribes' ancestral relation to the land and he resorted to the worst kind of savagist ideology when referring to the First Nations' way of life as, quoting Thomas Hobbes, "nasty, brutish and short" (Supreme Court of Canada). McEachern announced that Aboriginal title, the legal term for Aboriginal ownership over land, had been extinguished by the Crown in 1858. The Gitxsan and Wet'suwet'en appealed, eventually taking their case all the way to the Supreme Court of Canada. The court's text explaining the reasons for accepting the appeal and delegating the case back to the lower courts has acquired landmark status for defining post-Constitution Canada's

15 Brennan also refers to the conflict between land access and Native American religious freedom and how to deal with this: "Indeed, in the American Indian Religious Freedom Act (AIRFA), 42 U.S.C. $\$ 1996$ Congress expressly recognized the adverse impact land use decisions and other governmental actions frequently have on the site-specific religious practices of Native Americans, and the Act accordingly directs agencies to consult with Native American religious leaders before taking actions that might impair those practices" (US Supreme Court). Red Cloud's phrase runs somewhat like this: "The whites made us many promises but they never kept but one: they promised to take our land and they took it." 
criteria for accepting Indian land rights in the absence of any treaty. Chief Justice Antonio Lamer ruled, first, that Aboriginal title constituted an ancestral right protected by the Canadian Constitution; second, that Aboriginal title is a right relating to land sui generis, held communally and distinct from other ancestral rights. Aboriginal title is, therefore, in substance, a right to territory and encompasses exclusive use and occupation; third, that the evidence necessary for obtaining this status includes that the claimants have occupied the territory in question before the declaration of Canadian sovereignty and until the present; fourth, that proof of continuous occupation is sufficient if it includes the demonstration of a substantial maintenance of the bond between the people concerned and the territory; fifth, that oral evidence could be admitted as proof; and sixth, that Aboriginal lands could not be used in a manner that was inconsistent with Aboriginal title: if indigenous people wished to use the land in ways that Aboriginal title did not permit, then the land must be surrendered to the Crown (Supreme Court of Canada).

The Canadian Supreme Court's liberal attitude toward admitting oral tradition as decisive testimony in a case about logging and land rights must be seen as the result of western civil societies' serious attempts in recent decades to arrive at a more equitable understanding of the legal relation between settler colonies and their indigenous populations, both inside and outside the academy. While in the United States such progressive notions were drowned in 1988, a Canadian Supreme Court pointed toward a fairer way of regulating territorial conflicts ten years later. Clearly the Supreme Court's statement did not return any land to the tribes or grant them exclusive rights to the land. But it demanded that indigenous traditions, reaching much further back than the European presence, ought to be included in any legislation relating to ancestral lands. Delgamuukw is a landmark decision honoring landmark legends. Yet it also defined strict criteria for laying claim to indigenous rights, among them evidence of continuous occupation and of 'indigenous' use of the land: both of which imply a certain nostalgia for an indigenous culture exempt from historical change.

But this is not the end of both stories. The road into the Californian Siskiyou wilderness was not built after all. The construction was prevented by a wilderness protection act passed in 1990, result of the growing power of environmentalist groups. In British Columbia, on the other hand, negotiations about how to manage the land question amicably were initiated in 1998 but received a blow in 2016 when it transpired that some of the chiefs who had taken the province to court in the 1990s had now signed away the tribal rights for passage of a gas pipeline (TransCanada's proposed Prince Rupert Gas Transmission Project (PRGT). The 900-kilometer pipeline will carry liquid natural gas (LNG) from 
northeastern British Columbia to the Pacific North West LNG export terminal proposed for Lelu Island on British Columbia's north coast, crossing the territories of ten Gitxsan wilp groups along the way (Jang). The signers of this leaked contract include Chief Earl Muldon alias Delgamuukw, the name patron of the landmark case. Delgamuukw says that he and the other nine chiefs who accepted the money were acting out of honorable motivations-he says they wanted to invest the money into an urgently needed decent school building and a home for the elderly of the tribe (Jang).

The spatial and legal formations in colonial and postcolonial rimlands are messy and at times bordering on the absurd. Obviously, indigenous people do not always go to court to prevent the land from being destroyed (by logging, by the construction of pipelines). They do not always insist on their special rights of stewardship for merely spiritual reasons. Some of them also join the game of the globalized transnational economy, seeking to improve the situation of their communities by taking bribes from the extraction industry ( $\$ 5.3$ million CAD in this case). The case critically questions the functioning of the communities' political systems (and created a major crisis because the chiefs had not asked their tribal members for their consent but acted as old school patriarchs). But it also requires us to critically reflect our own expectations of how native tribes should contribute to the conservation of the environment and survive economically. The acceptance of the money by the chiefs clearly violates one of the conditions phrased by Supreme Court Justice Lamers in 1997-that Aboriginal lands be used in a manner that was consistent with Aboriginal title, i.e. consistent with a special "bond" between humans and the land, with traditional ways of land use. But isn't this qualification forcing tribes into an essentialist straightjacket by expecting of them that they act ecologically even in the face of poverty, economic hardship, and massive pressure from powerful economic players? To take this one provocative step further: Would the tribes who have recently opposed the north-south tar sands oil pipelines (Keystone XL and North Dakota Access Pipelines) likewise cease their opposition if they were among the beneficiaries of the oil and gas industry, by accepting bribes or by becoming shareholders? Anyone who has seen the sheer poverty on many reservations and indigenous communities should understand how difficult it is to resist the lure. We once again have to realize that the fault line runs not between 'nations,' or between Indians and non-Indians, but right through each community regardless of political and ethnic affiliations. While the respect attributed by the Canadian Supreme Court to indigenous landrelated stories and traditions is in constant danger of giving way to more cynical assumptions about Indian non-ecological behavior and savagery (which continue to exist even in the minds of judges, as we have seen), the Gitxsan elders 
have risked much more than their own social peace: their action resonates far and wide and across national borders into the realm of cultural mythology about Native Americans, one of whose items is the belief that they are protectors of the earth, not its destroyers. As in many cases of myth-making, both versions-the ecological Indian and the unecological savage-form part of the same cultural misunderstanding. Whether judges are attacking or defending their rights on the basis of that mythology, they are oblivious to sociological realities and to the fact that Native Americans, too, are subject to historical change. Indigenous people, as everyone else, never stop developing new means of coping in a political and social environment that is not very conducive to their cultural survival. In the last analysis both Canadian rulings deny cultural and legal coevalness to the indigenous claimants-one by regarding them as Hobbesian primitives, the other by forcing them into the straightjacket of romantic primitivism.

Thus the scorched earth and the poisoned ocean of Paul Lawrence Yuxweluptun's paintings are not the work of white people alone but of a whole extraction economy and mentality from which none of us is truly exempt.

\section{V}

In concluding, let me sketch a few aspects to be considered when talking about contested spaces (e.g. colonial contact zones, rimlands and 'subduction zones'):

1. Geopolitical considerations of the macrostructures and macropolitics of settler colonies will have to be combined with analyses of the microlevel (the fuzziness of various anthropological strata): how agents of transculturation, like elders, translators, traveler-scientists, teachers, contribute to 'making' those contested spaces; economic aspects have to be considered in conjunction with cultural aspects (as in Richard White's book on the Columbia River as an "organic machine"). Spatial orders are complex because of this human dimension, because of the continuous conflicts between residual, dominant, and emergent social forces in transnational and transcultural settings.

2. When talking about contested spaces, juridical and epistemic-cognitive dimensions cannot be excluded. Land and spatial control are not just 'grabbed' back and forth but these processes are accompanied by a legal discourse that deeply reflects, and enacts, cultural conceptions that are historically grown and contingent. Land transactions reflect and perform the power structures of a society and the power asymmetries of colonial contact zones.

3. The coloniality of such conflicts about land is reflected in legal, political and scientific discourses but those discourses interact with a deeper stratum of collective imaginations - the ideological DNA of a colonial society. Coloniality 
is not just a political and economic reality but an epistemic deep structure, as Walter Mignolo and others have shown. That deep structure does not only consist of identitarian elements like race- and gender-related ideologemes. The coloniality of knowledge also allows and disallows ways of knowing about space, place, and land. My examples are the concurrent archives of modern science (geology) and traditional indigenous stories-two archives whose conjunctions deserve more transcultural analysis: first, for getting a better understanding of how the earth actually moves and behaves; second, for understanding how people relate emotionally and intellectually to this seismic condition-how they continue to make a home in this land, owning it, claiming it, inhabiting it.

4. Including an anthropological-actor-oriented-perspective on space enables us to better confront neoliberalism's seductive offers to abstraction-of looking at land merely in the abstract, Lockean way (in terms of numbers, tables, empty space in identical squares of real estate to be cut up, sold, dug up, converted into concrete structures). There's a danger and a violence in this kind of abstraction, as the 'humanist' perspective reminds us. Because space is never empty but filled with life, human and non-human, with emotional attachment, and cultural knowledge. In short: space is always 'storied'. If we ignore the 'storied' quality of space, we unwittingly allow the world to be divided up between avaricious powers filling their stores with earthly wealth while swamping us with stories full of violence and denial.

\section{References}

Alatorre, Barbara. “'How Crater Lake Came to Be’: A Klamath Indian Legend Special for the Herald and News." Crater Lake Institute, 25 Feb. 2002, craterlakeinstitute.com/crater-lake-news/how-crater-lake-came-to-be.htm/.

Brown, Brian E. Religion, Law, and the Land: Native Americans and the Judicial Interpretation of Sacred Land. Greenwood P, 1999.

Chamberlin, Edward. If This Is Your Land, Where Are Your Stories? Finding Common Ground. Vintage, 2004.

Clark, Ella. Indian Legends of the Pacific Northwest. U of California P, 1953.

Cressman, Luther S. The Sandal and the Cave. 1981. Oregon States UP, 2005.

Cruikshank, Julie. Do Glaciers Listen?: Local Knowledge, Colonial Encounters, and Social Imagination. UBC Press, 2005.

Curtin, Jeremiah. Myths of the Modocs. Little, Brown, and Company, 1912. 
Deloria Jr., Vine. God Is Red: A Native View of Religion: The Classic Work Updated. Fulcrum, 1992.

Deur, Douglas. In the Footprints of Gmukamps. US National Park Service, 2008.

Duffek, Karen, and Tania Willard. Lawrence Paul Yuxweluptun: Unceded Territories. UBC Museum of Anthropology, 2016.

Echo-Hawk, Roger C. "Ancient History in the New World: Integrating Oral Tradition." American Antiquity, vol. 65, no. 2, 2000, pp. 267-90.

Echo-Hawk, Walter. In the Courts of the Conqueror: The 10 Worst Indian Law Cases Ever Decided. Fulcrum, 2012.

Engelstad, Diane, and John Bird. Nation to Nation: Aboriginal Sovereignty and the Future of Canada. Concord, Ontario: Anansi, 1992.

Gatschet, Albert S. The Klamath Indians of Southwestern Oregon. 2 vols. U.S. Department of the Interior/U.S. Geographical and Geological Survey of the Rocky Mountain Region. Washington, DC: Government Printing Office, 1890. Vol. 1.

Hogenboom, Melissa. “The First People Who Populated the Americas.” BBC, 30 Mar. 2017, bbc.com/earth/ story/20170328-the-first-people-who-populated-the-americas/.

Jang, Trevor. “B.C. Government Payments for LNG Support Called 'Bribery', Divide Gitxsan Nation.” Discoursemedia, 7 Feb. 2017, www.desmog. ca/2017/02/07/b-c-government-payments-lng-support-called-briberydivide-gitxsan-nation/.

Lippard, Lucy R. “A Free State of Mind Zone." Lawrence Paul Yuxweluptun. Unceded Territories, edited by Karen Duffek and Tania Williard, UBC Museum of Anthropology, 2016, pp. 85-97.

Ludwin, Ruth S., and Coll Thrush. "Finding Fault. Indigenous Seismology, Colonial Science, and the Rediscovery of Earthquakes and Tsunamis in Cascadia." American Indian Culture and Research Journal, vol. 31, no. 4, 2007, pp. 1-24.

Mason, Ronald J. "Archaeology and Native American Oral Traditions." American Antiquity, vol. 65, no. 2, 2000, pp. 239-66.

Mignolo, Walter. The Darker Side of Western Modernity: Global Futures, Decolonial Options. Duke UP, 2011.

Oakley, Christopher A. "The Center of the World: The Principle People and the Great Smoky Mountains." Landscapes of Origin in the Americas: Creation Narratives Linking Ancient Places and Present Communities, edited by Jessica Joyce Christie, U of Alabama P, 2009, pp. 3-14.

Quijano, Aníbal. "Colonialidad del poder, cultura y conocimiento in America Latina." Anuario Mariateguiano, vol. 9, 1997, pp. 113-21. 
Quijano, Aníbal. "Coloniality of Power, Eurocentrism, and Latin America." Coloniality at Large: Latin America and the Postcolonial Debate, edited by Mabel Moraña et al., Duke UP, 2008, pp. 181-224.

Schmidt, Peter R., and Stephen A. Mrozowski, editors. The Death of Prehistory. Oxford UP, 2013.

Shields, Rob. Spatial Questions: Cultural Topologies and Social Spatialisations. Sage, 2013.

Supreme Court of Canada. Delgamuukw v. British Columbia, [1997] 3 SCR 1010, 1997 CanLII 302 (SCC). The Canadian Legal Information Institute, Federation of Law Societies Canada.Web. https://www.canlii.org/en/ca/scc/ doc/1997/1997canlii302/1997canlii302.html.

United States Supreme Court. Lyng v. Northwest Indian Cemetery Protective Association. 1988. Legal Information Institute, Cornell U Law School, www. law.cornell.edu/supremecourt/text/485/439/.

Vansina, Jan. Oral Tradition as History. U of Wisconsin P, 1985.

Weisgall, Jonathan M. Operation Crossroads: The Atomic Tests at Bikini Atoll. Naval Institute Press, 1994.

White, Richard. The Organic Machine: The Remaking of the Columbia River. Hill and Wang, 1996.

Williams, Howel. The Ancient Volcanoes of Oregon. U of Oregon P, 1948. 


\title{
Steffen Wöll
}

\section{Spatiality and Psyche: Surviving the Yukon in Jack London's "Love of Life" and "To Build a Fire"}

\begin{abstract}
[O]ur expedition, running appalling risks, performing prodigies of superhuman endurance, achieving immortal renown, commemorated in august cathedral sermons and by public statues, yet reaching the Pole only to find our terrible journey superfluous.
\end{abstract}

Apsley Cherry-Garrard ${ }^{1}$

\begin{abstract}
This chapter argues that London's short stories "Love of Life" (1905) and "To Build a Fire" (1902) demonstrate the elusiveness of unequivocal interpretations of the Northland as a one-dimensional space of white supremacy in naturalist literature during the turn of the century. Going far beyond those ideas, London's placement of anonymous characters into a state of primitivism maps out mental geographies and trajectories of the white American psyche, which often counterpoint the racialist hierarchies that are regularly seen as dominating the era's discourses. Energizing alternative and more complex conceptualizations of imperialism and racism in the United States, I propose that the literary struggle of Anglo-Saxon "blond beasts" in the unforgiving sub-Arctic territory unpacks a number of psycho-spatial place-making dynamics through adaptation, transfiguration, and synthetic reconfigurations of body and mind that may best be examined through the lenses of Donna Haraway's "xenogenesis" and the Nietzschean concept of the Übermensch. Ultimately, Jack London's representation of the white psyche in the Northland reveals the many spatial frictions and philosophical pitfalls that are at the heart of a shifting American identity during the period of the nation's imperial outreach, adding to ongoing efforts to harness literary geographies as analytical instruments of interdisciplinary significance.
\end{abstract}

\section{Introduction}

When newspapers in July 1897 announced the return of a band of forty adventurers from the Klondike laden with gold worth around three thousand dollars, many self-declared gold miners and fortune seekers embarked on an

1 Cherry-Garrard 543 
onerous journey to the North. Among them was William D. Wood, the elected mayor of Seattle, who decided to resign from his office in order to 'strike luck' in the gold fields of the Yukon. The to-be celebrity author and social activist Jack London also fled the huddled masses of San Francisco in 1897, following the lure of gold and adventure (Wilma). However, he soon witnessed the relentless forces at play in the Yukon when he arrived at the foot of Chilkoot Pass, a steep bottleneck that marks the passage between Alaska and British Columbia on the most frequented route to the prospecting areas.

As he joined the ranks of a long procession of heavily laden men (some of whom had hired native packers and guides, whose services were in high demand) that climbed the narrow pathway single column, he learned about the harsh pecking order among the 'stampeders,' as the future prospectors called themselves. ${ }^{2}$ Jeanne Campbell Reesman relates London's experience at Chilkoot Pass, noting that "if anyone fell out of step, the line refused to let him back in, so he had no recourse but to return to the bottom and start over" (Racial Lives 59). ${ }^{3}$ The stories that Jack London penned inspired by experiences like these have deeply embossed the American imagination of the North as a space of adventure and hardship. Susan Kollin suggests that this influence goes

to the extent that even today readers and critics misrecognize the Klondike as US terrain. [...] Alaska and the Yukon were places to experience outdoor adventures and to test one's strength and stamina. In an era when Anglo-Saxon males felt themselves overwhelmed by the new immigration and feared becoming emasculated by domesticated life in the cities, the Far North was viewed as a last refuge, a safe haven for beleaguered EuroAmericans in search of invigorating outdoors experiences. This understanding has held such power that today, Alaska is still regarded as a space uniquely set off from the rest of

2 Although the Yukon was doubtlessly a dangerous region, Canadian authorities took some measures to discourage the most reckless stampeders by requiring specific equipment in order to be allowed to cross the border. This consisted of a year's supply of food and a minimum of thousand pounds of essential gear, including a waterproof blanket, six pairs of wool socks, two flannel shirts, and a medicine chest. The total load, often around two tons, had to be carried in stages by each man, caching one piece of gear in a camp and then making his way back on the trail to pick up the next (United States National Park Service, "Ton of Goods").

3 Sometimes, the harshness of the Northland resulted from the naivety and ignorance of the fortune seekers themselves. With minimal knowledge of the environment and conditions in the Yukon, at the beginning of the gold rush, many brought pack horses for whom the barren terrain did not provide enough sustenance. As a tragic result, thousands of carcasses were discarded in rocky crevices often called 'Dead Horse Gulch,' where their bones are piled up until today (Haley 103). 
the country, a position that provides the region with much of its symbolic capital in the popular imagination. (423)

Having weathered the dangers of the northward trek, London was frustrated to learn that most of the promising gold claims were already taken. Even more disappointing to the self-taught socialist, most of them were run by workers who were paid daily wages by capitalists, instead of making their personal fortune by 'striking luck.' Disillusioned, London moved into a free-standing cabin as soon as temperatures began to drop. While he did not find any of his dreamed-up riches, the twenty-three-year-old still got lucky as his cabin was located near a much-frequented crossroads. Throughout the long Arctic winter, many fortune seekers and seasoned prospectors (who referred to themselves as 'sourdoughs') were invited to his cabin's fireplace to share their, often incredible, experiences (Haley 110-12). It was during this period of simultaneous spatial isolation and intellectual stimulation that London's career as a serious writer really began. In fact, his most famous and critically acclaimed works are set in the Yukon. As soon as spring came and the ice melted, London, together with two companions, started back south from Dawson City, floating down the Yukon River in a selfmade boat to arrive at the Bering Strait, and finally California.

Back in San Francisco in July 1898, the novice writer, like many returnees, was suffering from malnutrition and scurvy. His disillusion grew as he observed the movement of Western civilization into the Northland, setting in motion its dilution as a 'pure' space of epic journeys and personal trials. As he lamented two years later in The American Monthly, the northern "[e]xploration and transportation will be systematized. [...] The frontiersman will yield to the laborer, the prospector to the mining engineer, the dog-driver to the engine-driver, the trader and speculator to the steady-going modern man of business" (74). Upon his homecoming, he also learned that his father John had passed away during his absence and that he remained as the only breadwinner of the family. To make matters worse, the national economy was heading towards depression. London had barely any marketable skills to boot. From his journey to the Yukon, he brought back no riches, having found mostly iron pyrite or 'fool's gold.' However, he carried home with him something much more valuable, namely a mind full of imaginations of the Yukon's human geography, which should soon find its expression in a number of stories that emphasize the brittle humanity and ephemeral wealth of the Northland through a style both widely accessible and profoundly complex. The first of these stories, “The Devil's Dice Box," London finished in September 1898, but the breakthrough came with the publication of "An Odyssey of the North" in the January 1900 issue of Atlantic Monthly. 
Suddenly, Charles Walcutt notes, "he was called the successor to Poe, the equal of Kipling, a new voice rising above the prissy sentiment of the genteel tradition" (16). But London's opposition to the 'prissiness' of the American Renaissance and his revival of white masculinity through the depiction of Anglo-Saxon 'he-men' is merely one possible, although extremely pervasive, interpretation of these stories. In fact, withstanding the urge of falling back to the same conclusions that have been made time and again and thus appear as almost normative seems a necessity when examining the following texts as spatial manifestations of the Progressive Era's white and male psyche. Earle Labor gives a fitting example for such a conventional deterministic reading of London's Northland as a space where " $[t]$ hose who survive are made better because of their adaptation to its laws; those who are weak in physical or moral character do not survive. This is the Darwinian ethic at its finest" ("Symbolic Wilderness" 151).

The pervasive nature of such interpretations poses a number of questions. First, should London's work thus be seen as an adulation of Nordic supermen who conquer and dominate the Yukon solely through their strength and courage? Second, does this space therefore turn into an idealized and ultimately sterile "zone of impregnable American innocence" (Blair 561)? Third, is the Northland's hostile environment a deterministic place-making factor that weeds out the weak and that London utilizes as a deus ex natura to conjoin the discourses of Social Darwinism, racialist white supremacy, and triumphalism of Western civilization? In the words of William Morrison, is London's spatialization of the Northland a literary avowal "that the Anglo-Saxon race, made especially healthy and vigorous by the bracing Canadian climate, would soon rise to take its rightful place of prominence in the world" (8)? While these issues are central for the following analyses of two of London's short stories that chart the journeys of white male protagonists in the Yukon, the preceding interrogation of the native space in the Northland already foreshadows the parochialism which binary answers to any of these questions would precipitate. In this chapter, I suggest that conventional readings of London's Northland as a racialized space of Teutonic triumphalism legitimized through the Spencerian survival of the fittest-while not entirely without purchase-should be revised to properly take into account London's idiosyncratic interplay between race, space, and psyche. As will be shown in the following analyses, the sometimes superhuman feats and struggles of white protagonists are mostly not mere celebrations of whiteness but stylistic devices that represent complex textual negotiations of spatialization processes propelled by environmental, psychological, and socio-economic dynamics. These dynamics often surface in the figure of the 'abysmal brute' as a key element of London's approach to naturalistic place-making and identity construction that 
refers to "a dormant regressive self [...] that helps [his characters to] adapt and survive, because as 'brutes' they are aware of their situation" (Reesman 8-9). Seen through the lens of spatialization, this brutishness, however, appears less as a crude celebration of Anglo-Saxon tenacity or superiority and more as a parable on the regenerative yet potentially fatal psycho-social effects of entering the primordial terrain of the Northland's human geography.

\title{
2 "Love of Life": Helpless Supermen in the Land of Little Sticks
}

\begin{abstract}
All living things contain a measure of madness that moves them in strange, sometimes inexplicable ways. This madness can be saving; it is part and parcel of the ability to adapt.
\end{abstract}

Yann Martel $^{4}$

Published in 1907, "Love of Life" tells the story of an unnamed protagonist lost in the northern wilderness. Struggling to make his way to the shore in the hope of finding an anchoring ship, he must learn the unforgiving lessons of survival in the Northland. Doing so, however, requires discarding or renegotiating of what society regards as 'civilized behavior.' In sober prose, the short story charts the struggle of its protagonist, referred to only as "the man," which already implies the universality of his condition and archetypal dimensions of his predicament. His comrade Bill has left him behind because he was slowing him down, and now the man must face the wilderness without the help and comfort of a companion. With no food and ammunition, he lacks any technological assistance apart from a tin bucket, a pocket watch that he winds meticulously, and exactly sixty-seven matches that he guards vigilantly, desperately counting them again and again, aware that they mark the fine line between him and an outcast Neanderthal in prehistory. He also carries with him a heavy bag that contains gold as the actual motive and the reason for his being in this situation. Initially, he clings to the learned patterns of civilization, and his first action is to try and define his positionality in the Yukon:

He looked to the south and knew that somewhere beyond those bleak hills lay the Great Bear Lake; also, he knew that in that direction the Arctic Circle cut its forbidding way across the Canadian Barrens. This stream in which he stood was a feeder to the Coppermine River, which in turn flowed north and emptied into Coronation Gulf and 
the Arctic Ocean. He had never been there, but he had seen it, once, on a Hudson Bay Company chart. ("Love" 742)

This mapping-out of the territory could be seen as an act of imperialism as it points to the power of Western geography to measure and take (at least intellectual) ownership of the Northland as terra nullius. However, unlike Brigham Young's famous act of Mormon place-making in 1847 by simply stating "this is the place" and thereby determining the location of what was to become Salt Lake City, London's protagonist cannot make the Northland his home simply because he is utterly isolated in it. He has no choice but to overcome the threats of the Northland's environment in order to make it out alive. After making up his mind, he decides to try and reach the Arctic Sea by traveling through a desolate region the natives call tit-chin-nichile, "the land of little sticks" (743). But rationality and technology, as becomes apparent, prove insufficient to cross this unsettled territory.

One morning the man wakes up and spots a caribou grazing right next to him; he then vainly pulls the trigger of his empty rifle driven by "the vision and the savor of a caribou steak sizzling and frying over a fire" (744). The man's intellect and 'common sense' fail him after he later stumbles upon a small pool, which to his disappointment contains only a single fish. Still determined to ingest some protein, he tries to catch it with his bare hands only to stir up mud and thus make the fish invisible for him. Putting his mind to the problem, he finally resorts to painstakingly scooping out all the water, only to discover that the fish must have escaped through a hidden crevice into an adjoining, much larger pool. Next, he comes across a group of wild birds and desperately hurls rocks at them. In the process, he even abandons his erect posture as a central tenet of his humanity as he "stalked them as a cat stalks a sparrow [...] till their ker-ker-ker became a mock to him, and he cursed them and cried aloud at them with their own cry" (746). Language as the differentiating feature between man and beast, it becomes clear, cannot help the protagonist in securing his 'rightful' place at the top of the food chain. This fact becomes even more evident when he vainly screams at a black fox that passes by carrying a bird in his mouth and refuses to surrender its prey to the man. As a consequence, the Northland in "Love of Life" becomes a stage for the spectacle of unfettered brutality of nature and humankind's forced participation in the struggle for survival.

This is demonstrated quite graphically in one of London's most disturbing depictions of the bestiality of a man stripped entirely from the vestments of civilization: Dizzy from hunger, the man stumbles and falls "squarely into a ptarmigan nest. There were four newly hatched chicks, a day old-little specks of pulsating life no more than a mouthful; and he ate them ravenously, thrusting 
them alive into his mouth and crunching them like egg-shells between his teeth" while the mother bird watches and squawks in protest (749). At this point, the controversial influence of Nietzsche's superman or Übermensch on London's writings comes to the fore, particularly because scholarly engagements with these issues have yielded contradictory results (Berliner 61; Furer 67; Kershaw 77; Petersen 65; Rothberg 569). Instead of providing an extensive overview of these interpretations, I will content myself here with asserting that the subsequent discussions are based in the conviction that Nietzsche in Thus Spoke Zarathustra (1883) did not envision the superman as racially superior. Instead, he or she is depicted as a highly idealized yet, nevertheless, human character that embodies positive values such as love, empathy, and creativity. After the 'death of God,' namely the idea that religion by itself can no longer engender meaningful identities, this figure would serve as a new blueprint for individual morality. In contrast to a deity, the superman is rooted in secular philosophy and untethered from spiritual escapism and the metaphysical realms of Paradise, Canaan, or hell. Arguably, this is what Zarathustra refers to when he proclaims: "You look upward when you long for elevation. And I look down because I am elevated" (28). For instance, Axel Gunderson's flawed character in "An Odyssey of the North," a frequently mentioned prototype of London's blonde supermen, can by no stretch of the imagination fulfill these high aspirations, which already casts doubt on the uncritical glorification of white supermen, or even proto-fascistic tendencies in London's stories. Similarly, the man in "Love of Life" is also white and of AngloSaxon heritage, yet his chick-eating savagery does not permit for any semblance of superiority, or even a shred of dignity from which his status as an Übermensch in a racial sense could be extrapolated. Conversely, the Northland as the supposed stage on which white dominance is celebrated emerges as an egalitarian and almost anti-anthropocentric space that testifies to the opposite by not discriminating between species and ethnicities. In fact, dependence on 'superior' technology or 'common sense' might actually be counterproductive, making the Westernized individual and society less fit for survival. Ultimately and in spite of his whiteness, the man appears just as distraught and 'primitive' as any member of any race who is struggling to stay alive. ${ }^{5}$

5 Still, it must be acknowledged that London partly admired Nietzsche for the philosopher's mention of the Teutonic heritage of the Übermensch. In a personal letter, he contends that "I have been more stimulated by Nietzsche than by any other writer in the world" (Letters 1485). In another correspondence, he seems less convinced and expresses his being "in the opposite intellectual camp from that of Nietzsche. Yet no man in my own camp stirs me as does Nietzsche" (Letters 1072). Examples like 
Unable to find a way of aligning himself with his environment, the protagonist becomes detached from a meaningful and therefore survivable relationship with his surroundings. For him, the Yukon turns into what Marc Augé called a "non-place," namely an anthropological limbo of transience in which he remains anonymous, invisible, and hence unable to carve out a space of subjective significance. As his most important staples of subjective significance, he must find water, food, and shelter to survive. But in the non-place of the uninhabited wilderness, his individual economy-and in abstracted form, that of Western capitalism in general-is uncoupled from the economy of the Northland, from which he cannot extract any benefit for himself. As a result, he must stand by and watch as the native animals successfully engage in their 'business', thereby proving their raison dêtre in a space that is desolate only for human beings. In this humiliating position, he emerges as an outcast and thus as the antithesis of a colonizing Teutonic zone-conqueror.

In his private life, London actually found himself in a similar non-place in terms of his racial and gender identity. He was raised by his de facto foster mother Virginia Prentiss, a former slave who was proud of her African heritage and with whose family he spent long stretches of time until the age of fifteen. After a troubled childhood and much discord with his biological single mother, London struggled to reconcile his positive subjective experiences with non-whites and the objectivized racism of the Jim Crow era. Overcompensating for social pressures to position himself within a distinctly white space, he discovered a sense of belonging - and maybe naive pride-in the notion of being part of a lineage of blond beasts that he had found in Nietzsche's work (Haley 62). In of his private photographs, London can be seen striking awkwardly 'manly' poses, presenting his white body as if to find reassurance in the authoritative eye of the camera. ${ }^{6}$

this stress London's difficulties in negotiating the contradictions between Nietzsche's philosophical utopianism and his own, much more pragmatic and crudely socialist worldview. Like many of his contemporaries, the autodidact London read Nietzsche with no academic background or philosophical expertise. As Walcutt notes, "the term 'superman' by itself had the power to inflame the imaginations of many who had never read Thus Spoke Zarathustra, and the rugged individualist supermen that emerged in popular literature-often ferocious blond Vikings-bore small resemblance to the type of genius Nietzsche described" (7).

6 These self-portraits lack the sensitivity that London employed in his travel photographs, where he eschewed staged exoticization of natives, instead portraying non-white people at work and in everyday situations, while simultaneously trying to buttress his own racial insecurities with the help of Nietzsche's supermen. 
London's protagonist in the story, however, is doubly lost: through his actual geographical 'maplessness' and geographical disorientation and also through his socio-cultural dissociation from the land of little sticks itself. In this situation, he is confronted with the choice to either realign the way he views and interacts with the environment or succumb to it. Put in more theoretical terms, the first step of this realignment lies in his realization that both time and space of the Northland work in unison against his survival. Heidegger's concept of "worlding," first formulated in Being and Time (1927), explores this notion by describing our relationship to space as an active process and a way in which we become familiar with and 'grounded' in our environment, leading to our meaningful sense of "being-in-the-world." Ben Wilson outlines the basic assumptions of the Heideggerian conception of existentialism:

Man is a Being-in-the-World in that he is aware of his existence, and he can become a Being-towards-Death as soon as he is aware of his potential inexistence (i.e. once he realizes he is mortal). Coming to terms with this fact allows for authentic Being, in which man knows that he is a Being-towards-Death. Authenticity in turn creates angst, an unfocused fear, as man realizes that he isn't at home in the world and will soon leave it.

The internalization of this existential fear then becomes the motivation for London's protagonist to flee the "land of little sticks" as fast as possible, even if it means crawling on his knees. In this state of primordial fear and survival, the Northland has turned into a "non-place": "What reigns [in non-places] is the actuality, the urgency of the present moment. Since non-places are there to be passed through, they are measured in units of time" Augé (104). Thus, dehumanized and degraded to "a mere automaton" "Love" (750), the man, however, eventually 're-naturalizes' himself by acknowledging that he has to renegotiate his own positionality within the spatial order of the non-place he traverses. But such a feat seems only possible through a process of worlding that involves shedding the now useless ballast of civilization and reconnecting with a more primordial self that burgeons in an instinctive understanding of spatiality. For London, the 'abysmal brute' becomes a metaphor for this return to a Heideggerian state of "authentic being" that discards the corrupting hierarchies and material excesses of Western civilization. In "Love of Life," the story's literary process of spatiopsychological realignment then involves the prospect of the individual's moral

7 David Trend describes "being-in-the-world" as a state of "signifying something ongoing and generative, which could not be reduced to either a philosophical state or a scientific materiality." 
rebirth as a Nietzschean overman who may herald the reformation of the then hyper-capitalistic American ecosystem, which London saw as unjust because it favored and celebrated the same inhumane ruthlessness that structures the Northland. In this way, the Yukon is subjected to a process of re-spatialization via its re-imagining both by the story's protagonist and reader as a space of solidarity and human geography instead of a stage of social Darwinism.

In order to "world" himself and thus become an "authentic being," the man must alter the way he thinks, feels, and imagines his surroundings, hence engaging in what could be described as spatio-psychological identity politics. On the one hand, this means that his personality changes as a result of his adapting to the hostile surroundings. On the other hand, apart from this adaptive and somewhat biologically deterministic process, it also reveals a psychological dimension of spatiality that concerns his mental relationship to the territory he negotiates in order to survive. After being abandoned by his companion, for example, he cannot allow himself to actualize the Northland as a space in which everyone fights for themselves and competes with one another. Instead, after positioning himself as a body-in-constant-movement to win the race against time in this non-place, he has to replace himself and actively think the Northland as a place of human solidarity and compassion: As "hard as he strove with his body, he strove equally hard with his mind, trying to think that Bill had not deserted him, that Bill would surely wait for him at the cache. $\mathrm{He}$ was compelled to think this thought, or else there would not be any use to strive, and he would have lain down and died" (743). Thinking about the environment and his position in it, the protagonist sets in motion a process of spatialization that results in an imagined order much more subtly and subconsciously constructed than, for instance, the christening of a colonial coast, the planting of a nation's flag on top of an embattled hill, or the drawing of a borderline on a map. Nonetheless, it shares the fundamental components of these examples of spatialization as it introduces order to a confusing situation, establishes new practices of space-related thinking, prepares new ways of acting for subjective actors, and produces spatial orders with potentially global outreach, in this case the public imagination of the Northland as it was shaped by London's human geographies.

As merciless as the law of survival in the Northland may be, the story suggests that its cruelty can be overcome through the 'humanization' of its geography and introduction of solidarity as the crucial element of reconciliation between animalistic nature and human culture. Bridging the chasm between the nihilistic struggle for survival and the chance for a Nietzschean rebirth of superior morality, London's introduction of solidarity and powerful 
demonstration of the fatal consequences of a lack thereof make "Love a Life" a precursor of more aestheticized social critiques like Lewis' Babbitt (1922) and Steinbeck's The Grapes of Wrath (1939). The man's final survival, as based in what London calls "the strength of the strong," ${ }^{8}$ is at its core not a Darwinist function rooted in physical, biological, or racial hierarchies. While the Northland may on its surface appear as an arena where the survival of the fittest, smartest, or most civilized could be openly celebrated, the story depicts psychological place-making processes and interpersonal solidarity as the actual sources of this strength.

Crawling on all fours and painfully crossing the final stretch of terrain to reach the saving bay in the Arctic Ocean where a whaling ship lays at anchor, the man eventually discovers the clean-picked remains of his disloyal companion Bill. To his surprise, he finds that Bill has clung to his share of gold until his very last moments; but the man's loyalty does not even falter in this moment as "he would not take the gold, nor would he suck Bill's bones" (755). Such unabated solidarity and preservation of humanity under the most adverse circumstance then also vindicates his survival during the final confrontation with a sick wolf that had pursued him for days. Both man and beast are too weak to attack and kill one another and are waiting for the other to die first. Having to commit a final act of barbarism by slowly chewing through the wolf's throat-the animal's blood "like molten lead being forced into his stomach" (757) - the man's perseverance stresses the deeply naturalistic assertion that he, like every other being, is inescapably a part of nature as a primordial space that is superordinate to human culture yet accessible and malleable through deep-running psychological and instinctual attunements.

The titular "Love of Life" then becomes the conciliatory element that is shared across all forms of existence, notwithstanding race, species, or ideology. Solidarity is the individual act of acknowledging this commonality and the concession of every being's right to live and to be given a fair chance in a collaborative, nonexploitative socio-economic order. Ultimately, London's own inclination towards and his audiences' ongoing fascination with this naturalistic solidarity accrue from the fact that it is one of the most stable, yet also most volatile, prerequisites of human coexistence. The Northland in "Love of Life" works as a setting that strips all cultural and ideological phantasmagoria from this insight, concurrently exposing the United States' shaky epistemic command of its colonial possessions

8 "The Strength of the Strong" is also the name of a short story published in 1911 as well as the title of a collection of London's short stories published in 1914. 
in 'exotic' parts of the world, which at the time of the story's publication already showed signs of their coming-apart.

\section{3 “To Build a Fire": Mind, Body, Death, and Xenogenesis}

[S]ometimes it takes more courage to live than to shoot
yourself.

Albert Camus ${ }^{9}$

First published in 1908, some critics regard "To Build a Fire" as London's best short story (Pizer 225). ${ }^{10}$ The plot revolves around yet another unnamed protagonist in the Yukon territory who is "a newcomer in the land, a chechaquo" (686; original emphasis) on his way to join his companions at Henderson Creek. Instead of using the "main trail [...] that led [...] to the Chilcoot Pass [sic], Dyea, and salt water" (225), he decides to take a rarely used shortcut, unknowingly entering a dangerous area covered with pools of water and treacherous streams coated with thin sheets of ice. The climate also turns against him when a cold snap hits in the middle of the gloomy Arctic winter. But the man does not realize the fragility of human life in temperatures of seventy-five degrees Fahrenheit below zero, in which his "spittle [...] crackled in the air" (687). While the husky at his side instinctively senses the dangers of traveling in such conditions, the careless protagonist remains largely unaware of the fatality of his situation as "all of this-this mysterious, far-reaching hairline trail, the absence of sun from the sky, the tremendous cold, and the strangeness and weirdness of it all-made no impression on [him]" (686). Tragedy unfolds when he breaks through the ice, wetting his feet and legs. To survive the ensuing race against time, he must build a fire as fast as possible in order to dry up before he loses command over his freezing body. Initially, he succeeds in getting a fire going, but after an avalanche from some nearby tree branches extinguishes the flames, the man-helpless without a human companion's assistance-finally succumbs to hypothermia as his dog sits by and watches him die.

Through its narrative style and plot structure, "To Build a Fire" underlines the antagonisms between two dichotomous epistemological paradigms. First, the knowledge that is accumulated by factual or 'objective' observations and

9 Camus 21

10 There also exists an earlier version of the story published in a 1902 issue of The Youth's Companion that differs in some aspects from the later and better-known version discussed here (see Hanssen 193). 
assessments, and second the knowledge that derives from experience and that solidifies into so-called common sense, wisdom, and finally instinct. Once again, the roughness of the Northland assumes its role as an agent that unveils the deadly consequences, but also the lessons that can be learned from the collision of these antithetic epistemologies. The protagonist, a neophyte in the northern space, has decided to base his travels in the Yukon purely on reason, namely on the (literally) cold facts and numbers concerning time, temperature, and distance of his trip: "Fifty degrees below zero stood for a bite of frost that hurt and that must be guarded against by the use of mittens, ear flaps, warm moccasins, and thick socks. Fifty degrees below zero was to him just precisely fifty degrees below zero. That there should be anything more to it than that was a thought that never entered his head" (687).

The third person narration deepens this technocratic attitude by assuming a detached tone that resembles a newspaper report in its factuality. At times, the narrator recedes so far from a style that would allow for personal identification with the protagonist that he seems like an ant under a magnifying glass whose actions the narrator dissects like a fascinated yet professionally distanced scientist. This sense of detachment is carried to extremes as the narration zooms out and the macro-geography of the Northland is focalized from a top-down perspective: "The cold of space smote the unprotected tip of the planet, and he, being on that unprotected tip, received the full force of the blow" (693). The text deepens this technocratic viewpoint via the repeated mentioning of data relating to temperatures and distances, thereby illustrating the man's increasingly desperate and misguided attempts to find solace in the realms of rationality and thus 'calculate' his way out of his predicament.

At times, he recalls the well-meaning advice of an old Klondike veteran he had met at Sulphur Creek and who emphatically warned him against traveling alone in temperatures below minus fifty degrees. However, the man discards the old-timer's warnings as "womanish," contending that "[a]ll a man had to do was to keep his head, and he was all right. Any man who was a man could travel alone" (693). ${ }^{11}$ Stating that to survive it is enough to just 'keep one's head,' which

11 Caroline Hanssen here observes some parallels to the fate of Christopher McCandless ("Alexander Supertramp") as popularized in Jon Krakauer's Into the Wild (1996). Like London's protagonist, McCandless was a neophyte in the Northland and ignored "several seasoned outdoorsmen offering [him] specific advice on the gear needed to hunt, camp, and travel in the springtime tundra; yet arriving at the head of the Stampede Trail, McCandless possessed only a collapsible fishing rod, a few field guides, a bag of rice, and a 22-gauge rifle" (193). 
he equates to 'being a man' then stresses the universal hubris that underlies the logic of Western exploration and zone-conquering of foreign spaces. In this conception, rationality, masculinity, and a reckless just-do-it attitude fuse together to form a combination of character traits that enables a man to discover, survive, and finally conquer any space. This becomes apparent in the manly deeds of explorers like David Livingstone, Fridtjof Nansen, Sir Ernest Shackleton, and Robert Falcon Scott, in whose dangerous adventures any sense of indecision in the life-threatening environments of Africa, the Arctic, and Antarctic resulted in the loss of masculinity because it jeopardized the lives, success, and prestige of the entire expedition.

Historically, this dynamic has often escalated in (sub-)Arctic places like the Yukon that are particularly hostile to human survival. The explorations of the North and South Poles, in particular, became deadly contests within the frameworks of imperialism and nationalism that turned into public spectacles of hyper-masculinity. In his final journal entry titled "Message to the Public," Scott insists that " $[\mathrm{h}]$ ad we lived, I should have had a tale to tell of the hardihood, endurance, and courage of my companions which would have stirred the heart of every Englishman. These rough notes and our dead bodies must tell the tale" (qtd. in Heffer). ${ }^{12}$ Unlike the celebrated polar explorers, London's man perishes anonymously and invisibly without an international audience to applaud and commemorate his feats-and therefore ultimately emasculated. He cannot hope for his remembrance as a hero of the North, but merely as a victim of his own recklessness or even foolishness. The neutrally detached tone in which his fate in the Northland is recorded lacks the pathos and male heroism emitted by such famous place and epoch-making texts like Scott's personal diary. Before his demise, the protagonist in fact forfeits all semblance of rational behavior and human dignity, going insane and "running around like a chicken with its head cut off" (699). He thus embodies what Japanese scholar Eijun Senaha calls "Men of Dis-ease," namely, those anti-heroes conceived by the 'lost generation' modernists who have "become powerless, lost, and then insane as their identities are shattered" (99).

12 A similar chauvinistic undertone and emphasis on masculine spatial metaphors can be found in the rhetoric of the Cold War's space race. John F. Kennedy, for instance, stated in his 1962 "Address on the Nation's Space Effort": Many years ago the great British explorer George Mallory, who was to die on Mount Everest, was asked why did he want to climb it [sic]. He said, 'Because it is there.' Well, space is there, and we're going to climb it. 
Throughout the story, the dog that accompanies him works as a counterpoint to this logic. The animal's relationship to its environment actually forgoes the need for manliness and rationality, relying merely on instinctive knowledge, which ensures its survival in the end. London contrasts the man's 'rationalized ignorance' of the cold with the dog's ingrained wariness: "This man did not know cold. Possibly all the generations of his ancestry had been ignorant of cold, of real cold [...]. But the dog knew; all its ancestry knew, and it had inherited the knowledge. And it knew that it was not good to walk abroad in such fearful cold" (691). Lacking this ancestral knowledge, the protagonist must rely on the experience and shared wisdom of others who have weathered similar situations. $\mathrm{He}$ must therefore integrate himself into a system of interpersonal solidarity, hereditary knowledge, and what Pizer describes as "racial wisdom" (222).

The protagonist's fatal ignorance of the lessons that others have drawn from their experiences finally stands as a critique of a solely rational understanding of space as opposed to an acknowledgement of a geography grounded in interpersonal solidarity and empathy. The hubris of the Anglo-Saxon explorer makes the man forget the vulnerability of his body because "he has internalized quantifiable sign-systems as the only way to read the world" (Gair 80). While he struggles for his life attempting to build a new fire, he looks at the dog and senses "a great surge of envy as he regard[s] the creature that [is] warm and secure in its natural covering" (695). Lacking such effective means of adaptation to the Northland, he tries to make use of his rational faculties to compensate for this deficiency. Weighing distances and temperatures, he ignores his ability to conceive of the dangers and inclemencies that lie ahead of him on the dangerous shortcut, disregarding his power of spatial imagination as the ability that could bring him closest to instinctive knowledge. As Labor suggests:

[T] he man who is to endure the long arctic winter must be exceptionally gifted in that highest of human faculties-imagination: he must understand the ways of the Northland so sympathetically that he can anticipate its emergencies before they occur, always adapting himself to nature's laws, never attempting foolishly to impose the frail, devious customs of society and civilization upon the inviolable wilderness. (152)

One the one hand, as Gair suggests, "To Build a Fire" can thus be understood as a cautionary tale that is part of "a transhistorical sub-genre ranging back to Greek mythology, the Bible, and to ancient China" (75). On the other hand, through its narratological adoption of the same technocratic ideology as its doomed protagonist, the story successfully develops its cautionary lessons along a fine line between irony and tragedy. In this way, the text amplifies its dramaturgical impact as Western audiences are prompted to find comfort in the sober 
reporting tone that ostensibly imparts the controllability of the Northland by registering all the 'objective' mistakes made by the protagonist. Human control, even over the most hostile natural spaces, is possible by following a certain set of objective and quantifiable parameters, the text-in the manner of a survival guide-seems to suggest. Whoever follows these rules is deemed rational and sensible, turning the death of those who succumb due to their ignorance of said rules into a logical, coherent, or even deserved result, and therefore an affirmation of the Darwinian and Spencerian survival of the fittest in nature and society.

In contrast to these narrative and stylistic implications of the story, the plot concurrently exposes the fatal hypocrisy of this spatial logic. Although the man has violated the rational rules of survival by traveling alone in extreme conditions, this is not what objectively kills him in the end and what could allow readers to shrug off his death as a logical corollary. Conversely, it is precisely his stubborn drive to objectively and rationally dominate the Northland that ultimately facilitates the dismal outcome of his journey. First, by dismissing the veteran's advice as "womanish" trumpery and thereby classifying it as unobjective, and second, by ignoring his own scruples as well as his dog's instinctive access to the environment's deadliness. Consequently, it is not a lack, but in fact an excess of objectivity that proves fatal for the protagonist. It is the Northland itself that works against him as a space that eludes its subjugation through Western technocracy, thwarting his attempts to survive by plotting out fires and frustrating his efforts to escape into mere rationality. Irrespective of his rational or irrational mindset, the story proposes, the Yukon does not permit for the man's subsistence and acts as an irresistible cosmic force that relegates him to the position of an ant under a magnifying glass, while replacing the lucid optics of scientific predictability with the opaque lenses of psychology, calamity, and instinctive knowledge. Jack London's representation of the Northland in "To Build a Fire," through its tragic-ironic double bias that oscillates between narration and plot, thus emerges as a counter-space to the hegemonic truth claims of Western epistemology anchored in rationality and so-called objectivity.

As another dimension of its spatio-psychological dynamics, the Yukon also facilitates the coming-apart of the unity between body and mind as a wholeness that is commonly seen as a given fact of 'civilized' existence. Exposed to the freezing temperatures, the man gradually loses sensation in his extremities; understanding that this will ultimately lead to his complete immobilization and death, he attempts to "kill the dog and bury his hands in the warm body until the numbness went out of them" (697). However, he is already unable to clutch his stiff fingers around the shaft of his knife. At this point, the cold has already 
disconnected his increasingly desperate mind from being able to assert control over his bodily movements. This disconnection becomes evident when he "look[s] down at his hands in order to locate them, and [finds] them hanging at the end of his arms. It struck him as curious that one should have to use his eyes in order to find out where his hands were" (697).

The direct transmission of volitional acts from thought to movement of the appropriate body parts has been severed. Hence, in order to exert command over his unfeeling hands, he must first look at them and thereby actualize them as being a part of himself because "the wires were down, and the fingers did not obey" (695), limiting the interactions between his mind and body to lineof-sight. ${ }^{13}$ In this fragmented state of self-perception, he is forced to mentally assemble an intact corporeal self from its individual constituents and-looking at his arms, legs, fingers, and feet-substitute his naturally assumed wholeness through an act of 'thinking himself as complete,' hence replacing instinctive unity with rational constructedness. This severing of body and mind becomes a signifier of the North as a space whose brutal environment dismantles the integrity and inbuilt romanticism of the humanistic anthropology of Enlightenment. In this distorted territory where mental and physical selves have become estranged from one another, John Locke's concept of mens sana in corpore sano is turned on its head as body and mind are forced to develop new strategies of cooperation, or both succumb. As a result, spatial alienation in the story turns into an intriguing metaphor for a central conflict in American society, whose dysfunctional (non-) collaboration between increasingly disjointed economic, cultural, and ethnic units and interests became a matter of concern during the Progressive Era.

In recent decades, scholars from various disciplines have scrutinized what it means if the human body-like the natural habitat that is being transformed by technology and what Leo Marx termed "machines in the garden"-becomes a site of intersectionality, fragmentation, and reconfiguration between instinctive, 'natural' processes on the one hand and artificial, techno-cultural overlays on the other. Commenting on the fragility and cultural significance of corporeal unity, Fredric Jameson suggested that

13 In an intriguing argument, Gair interprets London's usage of the wire metaphor "as [a manifestation] of an ideology indelibly affected by the telegraph" brought about by “[ $\mathrm{t}]$ he sparseness of London's prose, the repetition of standardized phrases, the portrayal of the mechanisms of the mind and body, the use of communications metaphors, and the conclusion's separation of the protagonist's mind and body" (75). 
we must distinguish between the body with organs and the body without. Paradoxically, this last, the inauthentic body which constitutes a visual unity and reinforces our sense or illusion of the unity of the personality-the body without organs-is the object of the pornographic and the glossy contents of so many images or strips of film. The body that has organs, however, and lots of them, to the point at which it disintegrates into a set of imperfectly reconnected 'desiring machines', that body is the authentic space of pain as such, pain you cannot see or express. (152)

The protagonist of the story is indeed the bearer of such a "body without organs" ${ }^{\prime 4}$ since he is no longer capable of experiencing pain in his numb extremities and is gradually separated from experiencing his body as an "authentic space of pain" situated within the Northland. Even though his external form appears intact, the space that surrounds him with its low temperatures and unseen dangers prevents him from becoming whole in the sense of existing as an "authentic" being. Only a creature of both inner and outer consonance, the story subtly suggests, is able to exist-or in this case, persist-'authentically' in a space of unbroken nature. Without complete access to his body, the man thus forfeits any kind of salutary relationship to the landscape in which he is positioned; the contact of his numb feet to the surface of the earth becomes abstract, dreamlike, and precarious. Tragically, he can neither realize nor overcome his fragmentation because culture and civilization have already removed him too far from a purely instinctive cooperation between body and mind.

In contrast to his dog, his corporeal geography is divided into center (brain) and periphery (extremities), whose movements are dependent on conscious impulses emanating from the center via so-called free will. This dependency then makes any wrong decision of the center-like his decision to attempt the shortcut alone-potentially fatal for the totality of his "being-in-the-world." The same logic applies retroactively, namely, when the man registers the accelerating decline and immobility of his margins, his center also breaks down as he starts

14 Gilles Deleuze first introduced the term "Body without Organs" (or BwO) in The Logic of Sense (1969) as an analytical concept further developed in his later works and collaborations with Félix Guattari. In Anti-Oedipus, they suggest that every actual body possesses a certain set of characteristics such as skills, traits, habits, etc. Apart from these, each body also incorporates another virtualized dimension of potentialities, which Deleuze and Guattari call BwO: "The body without organs is [...] produced as a whole, but a whole alongside the parts-a whole that does not unify or totalize them, but that is added to them like a new, really distinct part" (326). 
to 'lose his mind.' In a final act of desperation and body panic, ${ }^{15}$ both center and margins collapse after the man starts running down the trail while "[i]t struck him as curious that he could run at all on feet so frozen that he could not feel them when they struck the earth [...]. He seemed to himself to skim along above the surface, and to have no connection with the earth" (698). This passage underlines that both his mind-through the knowledge of the futility of this last-ditch effort-and his body-through its very disconnection from the ground-can no longer find purchase in the Northland, making him less of a zone-conqueror but a foreign body in this space. Donna Haraway employs similar concepts with regard to corporeal hybridity and fragmentation, exposing that

the traditions of 'Western' science and politics-the tradition of racist, male-dominant capitalism; the tradition of progress; the tradition of the appropriation of nature as resource for the productions of culture; the tradition of reproduction of the self from the reflections of the other-the relation between organism and machine has been a border war. (Simians 150)

Haraway negates the existence of an exclusive space from which humanity emerges as the apex of creation as claimed by Renaissance humanism and from which a 'natural privilege' to use resources may be derived (Simians 152). Instead, she proposes the deconstruction and subsequent re-configuration of the hierarchically structured binaries organism/machine, human/animal, and man/ woman. The corporeal ambiguity of the cyborg then demonstrates the validity of categorical in-betweenness or what Haraway calls "cyborg politics," namely, the conjunction of apparently opposing elements that unveils the essentialism of conventional identity construction. Referring to Chela Sandoval, Haraway goes on to argue that resistance through an "oppositional consciousness" can embolden such a cyborg politics as it favors affinity as a result of "otherness, difference, and specificity" (Simians 156). The processes that facilitate these assemblages of hybridity are captured in the concept of xenogenesis as the incurrence of corporeal Otherness. This concept refers to the transfigurations and reconfigurations that are expressed, for instance, by the intersectionality of subaltern bodies in Octavia Butler's fiction or Lynn Randolph's narrative paintings like ... and La Mestiza Cosmica Cyborg that visualize scenarios of synthetic intermixture between nature, technology, and the human body

15 In the decades after London's death, other variations of 'body panic' as the loss of a coherent sense of sovereignty over one's body came to the fore in the plots of science fiction and horror films like Invasion of the Body Snatchers (1956), The Fly (1958), or Alien (1979). 
in which the boundaries of a fatally transgressive world, ruled by the Subject and the Object, give way to the borderlands, inhabited by human and unhuman collectives [...]. These borderlands suggest a rich topography of combinatorial possibility. That possibility is called the Earth, here, now, this elsewhere, where real, outer, inner, and virtual space implode. The painting maps the articulations among cosmos, animal, human, machine, and landscape in their recursive sidereal, bony, electronic, and geological skeletons. (Haraway, "Promises" 328)

In "To Build a Fire," a comparable sequence of xenogenesis develops before the reader, minutely detailed through the breaking-apart of the protagonist's corporeal and mental faculties. Before he finally sits down and succumbs to hypothermia, the man has an out-of-body experience in which he joins a group of his comrades in the imaginary search for his own body on the trail, indicative of the complete coming-apart of body and mind. Whereas the man traverses the land solely through his mind (again viewing the Northland as an imaginary space or 'mindscape'), the text emphasizes the dual status of humanity's access to spaces that are real and violent, yet at the same time fictional and pastoral. The protagonist's imagined participation in social movement at the side of his companions is thus juxtaposed with his actual and fatal decision to 'go it alone.' In this way, the text puts emphasis on the validity of imagining geography and distinct, 'cerebral' mobility, yet at the same time visualizing the dangers of the individual's separation from socially shared patterns of spatiality. On the surface, the man's inability to physically escape his immobility in the Northland and his flight into fantasy may appear like a stereotypical example of naturalistic fatalism, which is often criticized as being overly deterministic and therefore antithetic to American values such as individualism and freedom of choice. In London's story, however, the man's ability to transcend his fixationalthough and precisely because this happens in the guise of a spatial imagination-together with his final admission of his mistake to ignore the old-timer's advice-overcome the fatal logic of determinism by demonstrating the possibility of change through the multidimensionality of the Yukon as a "rich topography of combinatorial possibility." Using Haraway's concept of the cyborg not only helps in understanding the overlaps and interplays of spatiality and psyche but also reveals the Yukon as a spatio-psychological borderland whose textual potential deconstructs and recombines such concepts as civilization and wilderness and body and mind, thereby synthesizing and hybridizing the physical realities of geography and climate with the immensely creative potential of human place-making.

Still ensnared in his hypothermic hallucination of social space and individual mobility, the man eventually comes "around a turn in the trail and [finds] himself 
lying in the snow" (699). Watching his own body in the process of becoming a part of nature, he finally breaks through the boundaries of rationalized separation from the Northland, recovering the mental and corporeal unity with his surroundings. Through this act of synchronizing imagination and reality and hence the xenogeneic maceration of the supposedly fixed borders between mental and corporeal access to imagined and real spaces, the man succeeds in repositioning himself meaningfully within the Northland's primordial landscape. London's human geography in "To Build a Fire" hence ultimately becomes a means to mediate between the dichotomies that traditionally separate nature and culture and, in this process, reveals the intersections between physical environment and psychological spatialization dynamics. The synchronization of internal and external spaces for the protagonist therefore leads to him finding peace and regaining dignity as he accepts that "he was bound to freeze anyway, and he might as well take it decently" (699).

\section{Conclusion}

Finally, and as the central insight conveyed by both short stories, the Northland exposes the interactions, intersections, and sometimes tragic contradictions between spatiality and psychology. Both "Love of Life" and "To Build a Fire" bring to the fore the depth and complexity of literary place-making strategies and techniques as well as the important role that falls to literature and culture studies in the exposure and analysis of spatialization processes as an underappreciated strand of research in the humanities. London's rendition of the Yukon reveals an exemplary richness of spatial formats and imaginations that far exceeds its conventional understanding as a mere arena of Anglo-Saxon triumphalism and blatant affirmation of deterministic Social Darwinism. Re-reading London through the spatial lens therefore emphasizes the potential of spatialization as a productive analytical category that can be used to gain new perspectives on and insights into supposedly 'settled' matters. Additionally, textual analysis performed from this angle allows for greater methodological openness and combinatory potential. Approaches that are traditionally regarded as extrinsic or far removed from each other-like the Nietzschean superman and Donna Haraway's concept of xenogenesis-can in this way be re-evaluated, freshly interrogated, and synthesized with beneficiary effects.

London's stories, at an early point and during an unlikely period in American history, enabled the formation of alternative and distinctly human geographies. But they also engendered an embryonic notion concerning the diversity and complexity of spatial imaginations which subverted the homogeneity of the era's 
dominant spatial metanarratives like Turner's frontier thesis as well as ethnocentric place-making concepts such as manifest destiny. London's depiction of the Northland as a realm of spatio-psychological re-combination must then be viewed as one of the spiritual predecessors of Anzaldúa's Aztlán, Gilroy's chronotope of the slave ship, and Silko's five-hundred-year map. Concepts like these not only subvert nationalistic and ethnocentric Euro-American geographies but also scrutinize contemporary epistemologies of space and place, hopefully inspiring renewed efforts of utilizing literary spatialization processes as a matter of increasing and interdisciplinary significance.

\section{References}

Augé, Marc. Non-Places: Introduction to an Anthropology of Supermodernity. Translated by John Howe, Verso, 1995.

Berliner, Jonathan. "Jack London's Socialistic Social Darwinism." American Literary Realism, vol. 41, no. 1, 2008, pp. 52-78.

Blair, Sara. "Cultural Geography and the Place of the Literary." American Literary History, vol. 10, no. 3, 1998, pp. 544-67.

Camus, Albert. A Happy Death. Translated by Richard Howard, Vintage, 1973.

Cherry-Garrard, Apsley. The Worst Journey in the World: Antarctic 1910-1913. vol. 2, Constable, 1922.

Deleuze, Gilles. The Logic of Sense. Edited by Constantin V. Boundas, translated by Mark Lester and Charles Stivale, Columbia University Press, 1993.

Deleuze, Gilles, and Felix Guattari. Anti-Oedipus: Capitalism and Schizophrenia. Translated by Robert Hurley et al., University of Minnesota Press, 2000.

Furer, Andrew J. “'Zone-Conquerors' and 'White Devils': The Contradictions of Race in the Works of Jack London." Bloom's Modern Critical Views: Jack London, edited by Harold Bloom, Bloom's Literary Criticism, 2011, pp. 55-72.

Gair, Christopher. "The Wires Were Down: The Telegraph and the Cultural Self in 'To Build a Fire' and White Fang." Bloom's Modern Critical Views: Jack London, edited by Harold Bloom, Bloom's Literary Criticism, 2011, pp. 73-90.

Haley, James L. Wolf: The Lives of Jack London. Basic, 2010.

Hanssen, Caroline. "You Were Right, Old Hoss; You Were Right': Jack London in Jon Krakauer's into the Wild." American Literary Realism, vol. 43, no. 3, 2011, pp. 191-97.

Haraway, Donna J. Simians, Cyborgs, and Women: The Reinvention of Nature. Routledge, 1991. 
Haraway, Donna J. “The Promises of Monsters: A Regenerative Politics for Inappropriate/d Others." Cultural Studies, edited by Lawrence Grossberg, et al., Routledge, 1992, pp. 295-337.

Heffer, Simon. "A Tale of Hardihood to Stir Any Man's Heart." The Telegraph, 28 Nov. 2009, www.telegraph.co.uk/comment/columnists/ simonheffer/6678674/A-tale-of-hardihood-to-stir-any-mans-heart.html/.

Heidegger, Martin. Being and Time. Translated by John Macquarrie and Edward Robinson, SCM Press, 1962.

Jameson, Fredric. Postmodernism, or, The Cultural Logic of Late Capitalism. Duke University Press, 1991.

Kennedy, John F. “Address on the Nation's Space Effort.” Rice University Stadium, Houston. 12 Sept. 1962. NASA, er.jsc.nasa.gov/seh/ricetalk.htm/.

Kershaw, Alex. Jack London: A Life. St. Martin's, 1998.

Kollin, Susan. Postwestern Cultures: Literature, Theory, Space. University of Nebraska, 2007.

Labor, Earle. “Jack London's Symbolic Wilderness: Four Versions.” NineteenthCentury Fiction, vol. 17, no. 2, 1962, pp. 149-61.

London, Jack. "The Economics of the Klondike." The American Monthly Review of Reviews, vol. 21, no. 1, 1900, pp. 70-74.

London, Jack. "Love of Life." Unabridged Jack London, edited by Lawrence Teacher and Richard E. Nicholls, Running Press, 1981, pp. 741-58.

London, Jack. “To Build a Fire." Unabridged Jack London, edited by Lawrence Teacher and Richard E. Nicholls, Running Press, 1981, pp. 686-700.

London, Jack. The Letters of Jack London, edited by Earle Labor, et al., Stanford University Press, 1988.

Martel, Yann. Life of Pi. Houghton Mifflin Harcourt, 2003.

Marx, Leo. The Machine in the Garden: Technology and the Pastoral Ideal in America. Oxford University Press, 1964.

Morrison, William R. True North: The Yukon and Northwest Territories. Oxford University Press, 1998.

Nietzsche, Friedrich W. Thus Spoke Zarathustra: A Book for All and None. Translated by Adrian Del Caro, edited by Robert B. Pippin, Cambridge University Press, 2006.

Petersen, Per S. “Jack London's Dialectical Philosophy between Nietzsche's Radical Nihilism and Jules De Gaultier's Bovarysme." Partial Answers: Journal of Literature and the History of Ideas, vol. 9, no. 1, 2011, pp. 65-77. 
Pizer, Donald. “Jack London's 'To Build a Fire': How Not to Read Naturalist Fiction." Philosophy and Literature, vol. 34, no. 1, 2010, pp. 218-27.

Reesman, Jeanne C. Jack London's Racial Lives: A Critical Biography. University of Georgia Press, 2009.

Rothberg, Abraham. "Land Dogs and Sea Wolves: A Jack London Dilemma." The Massachusetts Review, vol. 21, no. 3, 1980, pp. 569-93.

Senaha, Eijun. "Manhood and American Literary History: An Overview with Selected Bibliography of Masculinities and Men's Studies." The Annual Report on Cultural Science, 118, 2006, pp. 95-118.

Stein, Paul. "Jack London's The Iron Heel: Art as Manifesto." Studies in American Fiction, vol. 6, no. 1, 1978, pp. 77-92.

Trend, David. "Definition." Worlding, 3 Oct. 2012, davidtrend.com/?p=140 United States National Park Service. “Ton of Goods.” National Parks Service, nps.gov/klgo/learn/historyculture/tonofgoods.htm/.

Walcutt, Charles C. Jack London. Vol. 57, University of Minnesota Press, 1966.

Wilma, Dave. "City Council Appoints William D. Wood as Mayor of the City of Seattle on April 6, 1896." HistoryLink.org, 16 Nov. 2000, www.historylink. org/File/2796.

Wilson, Ben. "The 10 Best Movies Influenced by Heideggerian Philosophy." Taste of Cinema, 13 July 2015, tasteofcinema.com/2015/ the-10-best-movies-influenced-by-heideggerian-philosophy/. 


\title{
Thomas Plötze \\ Regional Homogeneity by Force or by Conviction? Central American Regionalism in a Long-Term Perspective
}

\begin{abstract}
This chapter reappraises Central American attempts of creating regional homogeneity in the long run since independence. At a first glance, the colonial, cultural heritage as well as the politico-economic developments make Central America appear as a firmly intertwined region. Traditionally, Central America has been characterized as a regional space par excellence. Looking at concrete historical attempts of regionalism, I argue that incidences of increased regional interaction alternated with periods of fragmentation. Seen from this angle, regional homogeneity has never been a result of a historical ever-growing process. Instead, I argue that regional homogeneity has been made and unmade in security narratives. Results from this chapter suggest that regionalism in Central America has always been inward-looking-either through paving the way for the spatialization of individual state spaces or through preserving the status quo in economic and political terms by suppressing intrasocietal resistance in each Central American country.
\end{abstract}

\section{Introduction}

The question of what defines Central America as a space varies according to the observer's perspective on this region as a space. In geographic-geological terms, Central America describes an Isthmus. It is the only area in the world that lies between two oceans (the Pacific and the Atlantic) and two (sub-) continents (North and South America) (Hall 5). Culturally, Central America can be defined as a culturally homogenous zone where some of the advanced civilizations had developed (Mayas and Aztecs), or as a frontier and interaction sphere pointing to its geopolitical meaning as a transit region (Creamer 45-49). Geopolitically, Central America has a particular trans-national relevance. Starting as an important port during the Spanish colonial system, Central America's transit position significantly augmented after its independence. Emerging world powers (the United States and Great Britain) intended to extend their influence in order to build a transoceanic connection through the Isthmus. The delineation of the five core states (Guatemala, El Salvador, Honduras, Nicaragua, and Costa Rica) as the building blocks for Central America finally refers to the shared historical and 
political development with the advent of Spanish colonization. ${ }^{1}$ Similar colonial and cultural heritage as well as politico-economic developments make Central America appear as a firmly intertwined region.

This points to the characterization of Central America as a regional space par excellence, as it denotes, traditionally, a historico-politically homogenous grown region (Sagastume Gemmell 25; Zinecker, Gewalt 107). Central American attempts to create regional homogeneity look very promising because "this region is rather unique, probably in the world, for any study of the relationship between peace, [regional, T.P.] integration, and foreign intervention" (Dabène 44-45). This implies that studies about Central American regionalism usually begin from the assumption of homogeneity as a rule and then continue to ask why so many exceptions have been appearing since independence. Usual explanations for these exceptions are the lack of political will or the institutional weakness. Contrary to that, I argue in this chapter that regional homogeneity has rather been an exception than a rule. I will show in the upcoming section that Central America experienced many failed, but also some successful, attempts of regionalism. ${ }^{2}$ Thus, Central American regionalism proceeded in waves. Incidences of increased regional interaction replaced periods of fragmentation. Seen from this angle, homogeneity within a regional space has never been the result of a historical process but, as I argue, the result of specific discursive formations. This chapter approaches Central America from a theoretical stance claiming that regions are the result of social constructions, made and unmade through discursive interactions (Bøås et al. 203). Regions are, therefore, one particular spatiality. This theoretical assumption implies looking at the processes of space-making from a regional perspective and asking how discursive narratives have been making and unmaking regional homogeneity rather than taking the homogeneity of Central America as a historical given.

1 During colonial times, however, this delineation was not fixed from its onset: For example, the peninsula of Yucatan, Chiapas, and Panama belonged to Central America until 1542, when Yucatan shifted to the audiencia of New Spain in 1560 and Panama towards the viceroyalty of Peru in 1567, becoming later part of the viceroyalty of New Granada in the 18th century. Finally, Panama sprouted into Greater Colombia (1819-31), subsequently Colombia, and only recently integrated into Central America during the last three centuries (see Hall 16; Karnes 9; MacLeod 23; Medina-Nicolas 81; Roniger 18).

2 I define regionalism as a regional project comprising a "programme and strategy which may lead to formal institution-building" (see Hettne and Söderbaum 34; Söderbaum 3). 
Since its independence, Central America has experienced waves of regionalization only in three periods (1820, 1850, and 1950-1960). These three waves have been the result of the specific configuration of an underlying security narrative. Attempts of creating regional homogeneity in Central America are successful when external security problems merge and align with an intra-societal threat perception. However, this merger has most often been highly unstable and is rather an exception than a rule. The second and third part of this chapter turns to the security narrative. It reveals how the security narrative influenced the making and unmaking of regional projects and is able to produce Central American spatial homogeneity within Central America. ${ }^{3}$

\section{Waves of Regional Homogeneity in Central America}

Waves of regionalism in Central America have always been inspired by the dream of a patria grande (Dym, "Central" 315), of a Central American state as the highest possible expression of regional homogeneity. This Central American dream has surfaced again and again from the 19th century until today. However, as this idea forms an important and almost stable element of the discursive repertoire, a reference to this dream obviously cannot explain the waves of regionalism in Central America. There must be something more, something that this chapter assumes to be the security perception. The aim of this part is to briefly reiterate the ups and downs of regionalism from the 19th century until the end of the 1970s. ${ }^{4}$ From this overview, I derive the peaks and nadirs of regional projects in Central America, to which I zoom in on afterwards to address their respective security narratives.

Central America has long-standing experiences in regional interactions. In fact, experiences of regional interaction in Central America date well back until the beginning of the nineteenth century, or even beyond if one were to consider the Spanish colonial rule as something similar to experiences of regional

3 Approaching Central America from this specific regional angle implies a certain limitation: I do not intend to provide a full-fledged account of the national developments in each Central American country. Since this has been done extensively elsewhere, I refer to some important national as well as international developments for the waves of regional homogeneity. For this, I refer to the outstanding contributions of Acuña Ortega; Bulmer-Thomas, The Political; Dunkerley, Power; MacLeod; Mahoney, "PathDependent"; Paige; Weaver, Inside; Williams; Woodward, Central.

4 From the 1980s onwards, Central America experienced three civil wars in Nicaragua, Guatemala, and El Salvador. This period until today is the object of my forthcoming dissertation project. 
interaction. What comprised and delineated Central America during the colonial rule was the result of the political-administrative assignment conducted by the Spanish empire. Officially, under the jurisdiction of the viceroyalty of New Spain (Mexico City), the main juridical and administrative center was the Audiencia, the General Captaincy of Guatemala. The central administrative and political authorities acted from Guatemala City. They comprised a handful of selected Spanish officials appointed by the crown (Roniger 25; Reza). The Guatemalan merchant elite controlled all external economic exchange with Spain as well as the internal trade within the General Captaincy between the provinces and Guatemala City (Floyd). The omnipresent power-nexus of administrative tax collection and economic control in the hands of this Guatemalan merchant elite came under pressure with the implementation of the so-called Bourbon Reforms. ${ }^{5}$ The final blow to colonial rule in Central America certainly emerged with the rather short establishment of the liberal constitution of Cádiz (Cortes de Cádiz) ${ }^{6}$ and the erection of a constitutional monarchy in Spain. The political turmoil and the conflicts among the Creole elites throughout the Americas as well as the independence war in New Spain (Mexico) supported the independence movement within the General Captaincy of Guatemala, which succeeded rather peacefully in 1821 (Roniger 25).

Despite some ideas of forming a confederation between different municipalities (Karnes 16-22) right after independence, the former Captaincy joined the Mexican empire in 1821. Two years later, however, the empire dissolved. From 1823 on, the former area of the Captaincy first formed the United Provinces of Central America and later declared themselves the Federal Republic of Central America $^{7}$ in 1824. With the federal constitution of 1824, the Central American federation imitated the US-constitutional model, at least formally (Dym, From Sovereign Villages 204). In fact, however, the federal political structure heavily

5 The Bourbon Reforms were an administrative and economic plan of reform elaborated after the War of Spanish Succession in 1714, first implemented in Spain and afterwards in the Americas. This plan of reform mainly aimed at strengthening the Spanish access to the economic surplus, a reform of administration and the beginning of economic liberalization in the colonies (see Pinto Soria; Wortman, "Bourbon" 233, 236-37).

6 The liberal constitution of Cádiz can be considered as a reaction to the forced installation of Napoleon's brother as the king of Spain in 1808, elaborated by Spanish forces in opposition to Napoleon. After the reinstatement of Ferdinand VII, the constitution was abandoned in 1814 and again enacted in 1820 .

7 The Federal Republic of Central America comprised Guatemala, El Salvador, Honduras, Nicaragua, and Costa Rica. 
relied on the colonial heritage of political administration granting largely autonomous power to the municipality level. The Central American federation signifies the first attempt at establishing regional homogeneity in the form of a regional and autonomous Central American state. This attempt lasted until 1839 when the federation dissolved into five independent countries (Roniger 26-27).

In addition to the failed attempt of the Central American federation, a second rather short incidence of regional cooperation happened in the middle of the 19th century. Central American historiography refers to the "war of independence" (Roniger 48) when the Central American countries in a concerted action fought successfully against the US filibuster William Walker. In 1853, William Walker arrived in Nicaragua. He intended to support one Nicaraguan political faction (Liberals) to fight against the prevailing power faction in the government. ${ }^{8}$ After a sweeping victory, Walker inaugurated himself as Nicaraguan president. Soon after, he even developed expansionist tendencies towards the other Central American countries. This provoked a concerted Central American action against Walker and his affiliates in 1856-57.

In terms of political economy, the period from the 1850s until the 1920s can be characterized as a period of increased economic development. The implementation of coffee (and banana) production led to economic growth, and the state capacity grew within each Central American country. ${ }^{9}$ The period until the beginning of the 20th century witnessed several regional initiatives but not even one unfolded into a lasting regional project. This long period of lack of regionalism therefore also needs further analysis in terms of the underlying security narrative. Constant intra-regional quarrels, conflicts, and destabilization led to the setting up of the first regional Court of Justice in Central America under the auspices and initiative of the United States. However, after its establishment in

8 William Walker was by no means the only filibuster sweeping into the Caribbean and Pacific area. US-filibusterism was a trend of the middle of the 19th century related to the US-expansion of the western frontier, the so-called Manifest Destiny and an attempt to find new potential territories to reproduce the US-southern states model of slave plantation economy, see May, Manifest; Medaglia Gómez.

9 This refers to the term "liberal reforms" in which coffee and to some extent banana production began on a large scale to be implemented in the Isthmus. The period of "liberal reforms" mainly experienced an enforced lock-in towards an export-oriented agrarian economy (sometimes called 'Coffee Revolution'). This implied a redistribution of large amounts of land, increasing the land concentration combined with more or less harsh measures to enforce and recruit sufficient amount of labor for the coffee fincas and banana plantations, see Brockett; Dunkerley, Power; Gudmundson and LindoFuentes; Lauria-Santiago; Lindo-Fuentes; Paige; Reeves; Weaver, Inside; Williams. 
1908, the Court closed in 1914 when Nicaragua became a de-facto protectorate of the United States. ${ }^{10}$

Until the 1950s, Central America followed the chosen agrarian-export-led development path. Despite severe economic setbacks (e.g. the Great Depression of the 1930s), the state capacity to control the social and economic means of production expanded through the evolution of professional military forces, which in turn ensured the domination of the elite. ${ }^{11}$ After the Second World War, regionalism experienced a new momentum in Central America through the establishment of three regional organizations in political (Organization of the Central American States, Organización de Estados Centroamericanos, ODECA), economic (Central American Common Market, Mercado Común Centroamericano, MCCA), and security issues (Central American Defense Council, Consejo Centroamericano de Defensa, CONDECA).

ODECA, established in 1951, acted as the institutional framework under which the "first ever customs union in Latin America" (Bulmer-Thomas, "The Central" 313) emerged (MCCA) in 1960. Resulting from an idea of the Economic Commission for Latin America and the Caribbean (ECLAC, Comisión Económica para América Latina y el Caribe, CEPAL), the main aim of MCCA has been to ignite industrialization through the implementation of a regional import substituting industrialization (ISI). ${ }^{12}$ Three years later, the Central American countries founded CONDECA. It was the first regional mechanism for consultation regarding questions of defense throughout Latin America (Saxe-Fernández 43), and it was institutionally integrated within ODECA (Briscoe 4; Smith 23). Its general goals were the maintenance of peace and collective security, collection of information and knowledge-sharing among the members, and the development as well as provision of "means for the coordinated employment of the armed or

10 This refers to the Byran-Chamorro Treaty directly intervening in Nicaragua and guaranteeing exclusive building rights for an interoceanic canal in Nicaragua, see Bulmer-Thomas, The Political 20; Karnes 191-93; Roniger 99.

11 The military acted as a kind of substitute in ruling the states for an economic elite, see Bulmer-Thomas, The Political; Dunkerley, Power; Holden, Armies; Mahoney, "PathDependent”; Mahoney, "Radical”; Zinecker, Kolumbien 101, 293-95.

12 For a theoretical discussion of ISI, see Hirschman. For a general discussion of MCCA, see Bulmer-Thomas, The Political 172; Hernández 137-41. Concomitantly, there emerged the Central American Secretary for Economic Integration (Secretaria de Integración Económica Centroamericana, SIECA) and the Central American Development Bank (CABEI, Banco Centroamericano de Integración Económica, BCIE), see Interiano Portillo 8; Fonseca and Ramírez. 
public security forces" (Smith 23-24). The United States facilitated the development of MCCA and CONDECA by providing financial support for the development of telecommunication and intelligence networks and of counter-insurgent capabilities with the deployment of the US Southern Command military branch (Holden, "Securing" 10-11; Dunkerley, The Long 75; Schmitter 4). While the overall success of those regional institutions was modest, MCCA experienced difficult times in the years 1969/1970 when first problems and signs of crisis emerged with rising indebtedness, fiscal problems, and overproduction. ${ }^{13}$ The so-called soccer war between El Salvador and Honduras in 1969 hit all three organizations very hard-an event from which they could never recover. Problems even aggravated with the Sandinista Revolution, as well as with the beginning (El Salvador) and intensifying (Guatemala) civil wars.

This rather short historical overview has highlighted three waves of intensified regional interaction: the Central American federation during the 1820s, the war against William Walker (1856-57), and the establishment of the three regional organizations of ODECA, MCCA, and CONDECA during the 1950/1960s. These three periods are the most visible expression of initiatives towards regional homogeneity until the 1970s. However, they all failed, and eventually heterogeneity prevailed. In the subsequent two sections, I zoom in on these three waves and reconstruct the underlying security perception to provide an alternative interpretation of the making and unmaking of regional homogeneity in Central America. My account thus confronts standard explanations that focus on missing political will or weak institutional configurations.

\section{The Making of Regional Homogeneity}

This section turns to the making of regional homogeneity in the three waves described above. I relate the peak of these waves to the respective security narrative. My findings suggest that Central America turns towards regional cooperation only under a specific configuration of the security narrative. When external threats merge and align with intra-Central American security problems, Central America experiences attempts of regional space-making. Intra-Central American security problems entail a perception of threat between different power factions, municipalities, and later on between the different Central American countries.

13 During the first decade, all participant countries of the CACM witnessed constant high rates of growth and the augmentation of the intra-regional trade as well as an increase in foreign direct investments and in the industry's share in the GDP, see Bull 960; Cable 664; Dolinsky and Stookey 77; Nuhn 493; Sánchez Sánchez 80, 82. 


\subsection{Central American Federation}

After the dissolution of the Mexican empire in 1823, Central America took its political future in its own hands and declared full independence from any external power. With a national constituent assembly beginning in 1823, Central America chose to develop towards a federal state and defined the political structure by distributing administrative, political, and judicative responsibilities between the ever-powerful municipalities, provinces (or states), and the federal state. Most studies take the independent provinces' decision about joining the federation for granted and rather focus on the institutional elaboration of the federation (Dym, From Sovereign Villages 195-225; Hernández 37). Only a few evidence in some sources point to the underlying security perception (Karnes).

Most authors who deal with this period highlight the prevailing particularism, frictions, and localism within Central America. Partly a result of the colonial heritage, these dividing lines of friction and sometimes hatred continued between the various provinces (e.g. between El Salvador and Guatemala or Nicaragua and Costa Rica), between different municipalities within the very same provinces, or between political power factions. Traditionally, historians interpret these multiple and often interwoven frictions along the divide between liberals and conservatives and characterize 'liberals' as pioneers of Central American federation, while they accuse conservatives of taking a contrary position which discarded the 'liberal' idea of a federal state (Hernández 24; Clegern $1-3)$. Historians thus argue that this divide contributed to alienating, conspiratorial, and suspicious tendencies throughout Central America.

When Central Americans feared their fellow citizens, or their provincial and municipal neighbors, a question arises why they opted for forging a federation after all and not for full independence of the provincial territories. I argue that this was due to a common concern for protection. This common concern arose because of a mutual and shared perception of external security threats. Various references to the security narrative point into this direction. Following these references, security threats-though mostly vague-related to a resurgent Mexico, or even worse: "[a]lways there was the fear of intervention or reconquest by Spain. Modern scholarship generally scoffs at the danger, but the enunciation of the Monroe Doctrine in December, 1823, was a North American symptom of a threat that the Central Americans felt most intensely" (Karnes 46). Other evidence points to rumors of a furious Simon Bolívar aiming to integrate the Central American provinces into a Colombian monarchy (46). Those rumors of outside menaces lie underneath the explanation of why Central America forged a federation, despite their fierce local grievances. For a short period, these 
perceived outside threats led to a union between the different Central American power factions (economic elites, municipalities, etc.) in order to prevent an external intrusion (46).

However, it seems that the perception of external threats was too hazy and abstract in order to overcome differences between internal power factions. Soon after the formation of the federation, internal quarrels and armed conflicts were again on the rise. ${ }^{14}$ These internal conflicts and wars finally led to the fragmentation and dissolution of the federation, which I analyze in more detail in the third part of this chapter. At first glance, the Central American federation might have symbolized the highest expression of regional homogeneity; however, in practice, "the Central America of 1824 was not a nation but a league of towns, suspicious of each other and linked only by common concern for protection" (Karnes 92; Dym, From Sovereign Villages 177).

\subsection{The War of Independence-William Walker}

A manifest external threat as an impetus for collective identity creation on a federal level (Karnes 135; Roniger 25) finally unfolded during the 1850s when William Walker posed a serious threat to all Central American countries. The gateway for entering Central America was the severe and ongoing civil or municipality war between León and Granada in Nicaragua-an ongoing conflict dating back to earlier times of the federation. Being invited by the power faction of León (Liberals) in 1853, Walker's entry into Central America was the result of a mutual threat perception between León and Granada (Karnes 140). However, the local friction between León and Granada was only a beginning, and Walker's venture was by no means solely a private Filibuster enterprise. International developments certainly had an influence on this issue as well. On the eve of the US-American civil war, Manifest Destiny, the inherent urge to find new slave states outside of the US confederate states and the intense conflict between the United States and Great Britain about the Nicaraguan canal certainly influenced Walker's initial success in Nicaragua. ${ }^{15}$

14 " $[\ldots]$ and they had even missed the cohesive influence of a common military enemy when they obtained independence. Now, free, there were dangers, but they were vague and diversified [...]" (Karnes 55).

15 Manifest Destiny and pro-slavery factions in the United States supported the US-filibusterism, see Medaglia Gómez. At the onset of the 1850s, the quarrels between the USA and Great Britain about a Nicaraguan canal became very intense. Besides Belize (British Honduras), Great Britain held some colonial territories at the Caribbean rim of Central America (Mosquito Coast). Even the Clayton-Bulwer Treaty, 1850 could 
The expansionist aspirations of Walker provoked a regional reaction from neighboring Central American countries. Around 1856, fear became prevalent that Walker could extend his aspirations (Medaglia Gómez 5). As a reaction, Costa Rica, El Salvador, Guatemala, and Honduras forged a military alliance to overthrow what Central Americans perceived then as an "extra-regional" threat (Hernández 67; Roniger 48). Certain alienated Nicaraguan power factions as well as Cornelius Vanderbilt even supported the military alliance, intending to oust an internal competitor faction (Loveman 111; May, The Southern 102-03). The successful push back of the Walker intermezzo in Nicaragua relied on a successful attempt at defining Walker as a unitary, external security threat, which successfully merged with an internal security threat perception. However, this was only short-lived. When Walker lost and left Central America, so did the external threat perception, and Central America fell back into old patterns of oppositional disagreements.

\subsection{The Trinity of Regional Organizations-ODECA, MCCA, and CONDECA}

This particular configuration, that is the merging of external and internal threat perceptions, once again was prevalent during the establishment of the three regional organizations after the Second World War. Thus, it was to a lesser degree political and economic considerations that explain regionalization in this period. On the contrary, the specific security perception played a decisive role, even for the establishment of the common market (MCCA).

Three Central American and international developments are significant for the security perception that became so characteristic of the 1950s and 1960s: (1) With the onset of the Cold War, Communism was of immediate concern to the Central American countries, especially against the background of the so-called Guatemalan Revolution. ${ }^{16}(2)$ Both the successful Cuban Revolution at the end

not calm down the dissension between both powers, see Harper's Weekly; Leiken and Rubin 72-73; May, The Southern 86-88.

16 Guatemala witnessed a so-called revolution between 1944 and 1954: Military dictator General Ubico was ousted in 1944 through popular uprising and the subsequent elections meant the emergence of a social-democratic government with a clear politicoeconomic project of reforming and redistributing the agrarian sector (especially since 1951). The Arbenz government was however ousted in 1954 by a concerted action and intervention of CIA, Guatemalan forces, and with more or less open support of the neighboring Central American states, Handy, "National"; Handy, "The Most"; Handy, "Insurgency"; Handy, Revolution; Gleijeses, "The Agrarian”; Gleijeses, Shattered. 
of the 1950s as well as the US-initiated Alliance for Progress ${ }^{17}$ heavily influenced the security perception. (3) The emergence of guerrilla insurgencies and leftwing anti-regime groups within various Central American countries (especially in Guatemala) likewise affected the security perception.

The security perception of an identifiable external menace (Cuba) and the emergence of local insurgency movements provoked the establishment of the trinity of regional organizations. Right from the beginning of the foundation of ODECA, the alleged Guatemalan communist experience and the socio-economic reforms it undertook led the other Central American countries to fear the rise of potential popular expectations in their own countries (Dabène 48; Karnes 240). Further evidence suggests that the Central American countries feared, on the one hand, a possible external communist intrusion, and on other hand, they viewed the Guatemalan experiment as an immediate communist threat at their doorstep (Selser 30-31). ${ }^{18}$

The internal and mostly potential threat, Communism, merged with a clearly identifiable external menace, the Cuban Revolution: without doubt, the formation of the MCCA also had economic grounds; and surely, there is also a time coincidence between the MCCA, the Cuban Revolution, and the Alliance for Progress. But the MCCA could only take off after the final approval and support of the United States through its genuine anti-communist program (Sánchez Sánchez 57; Cable 670; Posada and López 56). Economic stability and prosperity became an important ingredient of the security narrative because "[c]ommunism is the chief obstacle to economic development in the Central American region." ${ }^{9}$ While the MCCA aimed to fight the threat economically, CONDECA-founded around the same time-was concerned with the political stability of the Central American countries. External and internal threats merge at this moment: On the one hand, " $\mathrm{t}] \mathrm{o}$ Central American military planners the threat of Fidel Castro's brand of communist aggression is very real, and they are determined to keep the Communists from overrunning the Isthmus"(Smith 25). On the other hand, there was widespread fear of the potential emergence of subversive forces from within the Central American societies themselves: "The Cold War and the

17 As an immediate response towards the Cuban Revolution, then US President John F. Kennedy initiated the Alliance for Progress for Latin America with the aim to prevent any future 'Cubas' in the western hemisphere. This multi-million dollar development program included, for example, social welfare measures and also Agrarian reforms.

18 In contrast to this, Schmitter argues that CONDECA was founded based on an initiative from Guatemala and Nicaragua in 1961, Schmitter 37-38; Saxe-Fernández 41.

19 US President Kennedy qtd. in Nairn 21, which refers to the Declaración de Centroamerica, adopted in San José, Costa Rica, in 1963 (see Fernández-Shaw 164-70). 
guerrillas were the only significant threat or enemies. Some of these threatened the survival of the military regimes" (Sánchez Sánchez 128).

After the Second World War, the trinity of regional organizations followed the clearly identifiable aim to install an inter-governmental form of regional homogeneity in order to subvert any potential anti-systemic tendencies in Central America. Thus, this emerging regional space served as a means for maintaining the status quo. Under the framework of ODECA, MCCA aimed at economic stability and-to some extent-relief, and CONDECA was "explicitly designed to thwart internal subversion and to act as the penultimate guarantor of the dictatorships of Central America [...]" (Dunkerley, The Long 75).

The successful merger of internal and external threat perceptions during this period suggests that this specific configuration of the security narrative had a powerful discursive impulse. This time, the external threat was clearly identifiable (Cuba and Communism). The internal threat, however, remained rather vague, less graspable, and dispersed in the form of anti-systemic and leftist-resistance groups. ${ }^{20}$ When this specific security narrative no longer corresponded with intra-regional threat perceptions, not very surprisingly, the trinity of regional organizations imploded. In the next part of this chapter, I turn to this implosion and to the unmaking of other examples of regional homogeneity.

\section{Central American Heterogeneity as the Rule}

So far, the main argument has been that regionalism in Central America unfolds when the security perception of internal and external threats merges. For the unmaking of regional homogeneity, I claim that a different configuration of the security narrative is the underlying factor. Evidence in the following three examples suggests that regionalism dissolves when intra-Central American threat perception dominates, leading to regional heterogeneity as the predominant paradigm.

\subsection{Dissolution of the Central American Federation}

As indicated in the second part of this chapter, the Central American federation finally dissolved in 1839 . Very soon after the formation of the federation, internal conflicts and quarrels broke out. Evidence suggests that the predominant security

20 With the exception of Guatemala, which witnessed the formation of the Fuerzas Armadas Rebeldes (FAR) right after the ousting of Arbenz, resistance and leftist movement remained rather under the radar in the other Central American countries. 
perception focused on intra-Central American foes and threats. This implies that the diffuse and vague external threat perception at the initiation of the federation vanished in favor of an intra-societal threat perception.

The specific security narrative predominant during the federation has its roots in different historical explanations of the failure of union. Whether one refers to the prevailing schism between Liberals (hotheads) and Conservatives (Serviles) (Weaver, "Reform" 133; Woodward, Central 90; Woodward, "Economic" 565), or to the politico-economic divide between the federal center and the provincial peripheries (Patch 97; Floyd 99-100; Niemann 147; Williams; Wortman, "Government" 275), or to the predominant municipal character of the conflicts (Dym, "Our" 466), the underlying security perception of intra-Central American threats nevertheless prevails. Certainly, the poor federal performance in economic and political terms had an influence on the dissolution. From a security narrative perspective, however, these alleged political and economic factors convey the same configuration of the security perception. Constant envy and competition on the world market due to the specialization in similar export products furnished grievances between different factions of the elites. Ideological and political quarrels between neighboring municipalities conveyed a picture of constant, but also shifting, threat perception. ${ }^{21}$ Whether one perceives one's neighboring municipality, fellow citizen, or rival power faction as a threat because of ideological, economic, or political reasons lastly plays a minor role. The prevailing factor is the perceived intra-Central American threats. This configuration remained in the background of the numerous internal civil wars, armed conflicts, and skirmishes ${ }^{22}$, which finally culminated in the war between Francisco Morazán and Rafael Carrera resolving the ongoing process of dissolution within the federation. ${ }^{23}$ Taken together, an external threat perception merged with an internal

21 Remnants of the colonial empire, municipalities could maintain their powerful position after independence and during the federation by establishing multiple power centers: "The greatest challenge these independence leaders faced, whether they sought to relocate power to state or federal government, was getting cities to stop acting like sovereign states" (Dym, "Our" 466).

22 Karnes lists in total 51 battles for Guatemala, 40 for El Salvador, 27 for Honduras, 17 for Nicaragua, and 5 for Costa Rica during 1824 until 1842 (94).

23 In the final stages of the federal republic, opposition arose from the Guatemalan Highlands, especially Los Altos wherein Rafael Carrera, as a military leader quickly evolved as the conservative challenger of the perceived "true Central American" Francisco Morázan, see Clegern 1-3; Karnes 69; Riekenberg, “Die Rebellion”; Riekenberg, Ethnische; Weaver, Inside 54, 58; Weaver, "Reform." 
one even before the formation of the federation for a short time. This discursive configuration took a back seat in the narrative beginning in 1826 . With only a hazy external threat perception, intra-regional threat perceptions between different factions became the dominant configuration of the security narrative leading to constant armed interferences or wars.

\subsection{Regional Heterogeneity in the Long 19th Century}

A similar argument emerges with the long 19th century. One may raise a question why the moment of regional cooperation did not last longer after the successful ousting of William Walker. Again, I refer to the specific configuration of the security narrative: the moment of regional cooperation was short-lived because the external threat broke away almost immediately with the defeat of Walker, while the intra-regional threat perception prevailed and even intensified.

Even though Central Americans attempted to reunite or establish some form of regionalism after the 1850s, none of these initiatives lasted for long. These attempts mainly remained unilateral experiments by individual presidents or dictators to reunite the federation by occupying, interfering with, or sometimes inserting politically more sympathetic elite fractions in their neighboring states. Two very active presidents were the Guatemalan President Justo Rufino Barrios throughout the 1870s and 1880s (Karnes 161-63), and the Nicaraguan President José Santos Zelaya (Karnes 167-74).

Evidence suggests that the main threats described as intra-Central American, as grievances between neighbors, constantly changed the threat perception as alliances among the states continuously shifted. Guatemalan (i.e. Barrios's) "[...] forces invaded El Salvador, in the usual manner of aiding the party out of power, and succeeded in installing a more cooperative president, while Guatemalan troops were still present" (Karnes 153). These military initiatives by Barrios and Zelaya either failed almost immediately or met with fierce resistance from the attacked countries (Palmer 529). Whether both figures really intended a reestablishment of Central American unity or "[...] they [only] constantly meddled in the affairs of the other states in the name of Central American union" (Karnes 167; Palmer 516) is of secondary importance. These examples point to the predominant security perception, in which intra-Central American threats provoked neighboring interferences, influences, and military conflicts. The overall idea or dream of a patria grande degraded at best to a label for the intra-Central American security perception by individual Central American countries. 


\subsection{The End of the Regional Trinity}

The trinity of regional organization experienced a major blow at the end of the 1960s from which it would never recover, again, as I argue, due to a change in the previous configuration of the security narrative. The merging of external and internal-mostly intra-societal-threat perceptions retreated in favor of intra-regional threat perceptions. In other words, what started as intra-societal menaces, for example, in El Salvador and Honduras, eventually turned into intra-regional threats and even into a war between both countries.

Economic factors influenced the dissolution of the MCCA according to the majority of the available explanations (Bulmer-Thomas, "The Central" 315; Sánchez Sánchez 89). According to these studies, massive trade balance disparities between the member countries as well as the lacking support, or open opposition of the most important economic power faction in Central America (the agrarian oligarchy) deprived the MCCA of any serious attempt to follow the ISI-model (Bulmer-Thomas, "Economic" 292; Bulmer-Thomas, The Political 175-76, 184-85; Cable 668-69; Nuhn 494). The result was the continued deterioration of the financial capabilities of the MCCA member states. In addition to these economic factors, and even more important for the purpose of this chapter, I argue that the change in the configuration of the security narrative is the explanatory factor for the dissolution of MCCA as well as of the other two regional organizations. The soccer war between Honduras and El Salvador may have popped up all of a sudden, but the underlying security narrative suggests that the threat perception changed during the 1960s. This was perhaps reinforced by economic factors.

The soccer war between Honduras and El Salvador broke out after a series of world cup qualifiers between both the countries. The war lasted from July 14 until 18, 1969. Even though the soccer games might have been the igniting events, threat perceptions between both the countries were already tenaciously high. Two unsolved issues explain these perceptions: (1) the trade conflict, as the economic development of El Salvador was merely to the detriment of Honduras (Cable 660). (2) During the preceding decades, around 250,000 Salvadorian peasants occupied and cultivated Honduran territory because of the increasingly high land pressure in El Salvador (Posada and López 58). For the El Salvadorian elite, the out-migration of peasants to the neighboring Honduras functioned as a safety valve for potential intra-societal unrest and socio-economic demands. In turn, resentment against the Salvadorian migrants arose in Honduras due to an anxiety about increased labor competition and accusations towards the 
Salvadorian politico-economic elite. ${ }^{24}$ The soccer war and the underlying threat perception thus show that intra-societal fears in each country switched towards accusations between both countries, as "[...] fue una lucha entre las fracciones de las burguesías dominantes en cada país. La salvadoreña buscando mantener su hegemonía sobre el campesinado y dentro del bloque de poder; la hondurena, tratando de resarcirse de la grave situación socioeconómica que afrontaba el país"25 (Posada and López 59).

Looking at the security narrative in this example, its configuration resembles in large parts with those reconstructed in the other two examples of unmaking regionalisms. Security narratives, which entail intra-Central American threat perceptions, have a dissolving impact on regionalism. Especially this last example of the 1960s reveals that when intra-Central American threats gained the upper hand, regional homogeneity dissolved. With the end of the soccer war, Honduras drew out of the MCCA and CONDECA, leading finally to a standstill of ODECA (Aguilera Peralta 154; Isacson 14). Thus, the trinity of regional organizations, initially aimed at preserving the economic and political status quo in each Central American country, received a major stroke because of a change in the security narrative configuration. What began as a merger and alignment between an external (Communism) and an intra-societal threat (leftist movements) turned into an intra-regional threat perception. In other words, the initial unity in threat perception switched back towards the (historical) rule of mutual grievance.

\section{Conclusion}

The aim of this chapter has been to put forward the argument that the security narrative has been responsible for the (un-)making of regional homogeneity in Central America. This argument provided a reinterpretation of the prevailing explanations, suggesting that the waves of regionalism in Central America cannot solely be explained by a lack of political will and/or weak institutions. I related these waves of regionalism to the underlying security narrative in three examples.

24 "The Salvadorian Government has been criticised for exporting its social problems rather than solving them, and Honduran propagandists have drawn attention, for propaganda purposes, to a feudal oligarchy of 'fourteen families' who supposedly own most private property in El Salvador" (Cable 659).

25 "[...] it was a fight between the fractions of the dominant upper classes in each country. The Salvadorian [fraction] was attempting to maintain its hegemony over the peasantry and within the power block; the Honduran [fraction] was intending to recover from the severe economic situation which the country faced." (own translation) 
This reinterpretation has provided the following results and reference points for further analysis. In terms of regionalism, the historical examples indicated that from a regional perspective, homogeneity in Central America was rather an exception than a rule. One may even reach to a conclusion that regionalism in the long durée mainly had two functions: (1) Regionalism acted as the ideal background for state formation and the consolidation of the Central American states during the 19th and until the beginning of the 20th century. Though seemingly at odds with the historical fact that regionalism was only present for a longer period during the federation, the idea of Central American unity was always around in the discursive repertoire. However, this idea mainly served as a discursive background under which internal quarrels and wars divided Central America into individual state spaces. Regionalism may have initially started from homogeneity in 1824 but eventually evolved into regional heterogeneity. Thus, regional space-making lastly paved the way for the creation of individual state spaces. (2) Regionalism as a background changed after the great depression of the 1930s. Though potentially forged under the dream of unity, regionalism in the form of the trinity of regional organizations mainly aimed at preserving the status quo in economic and political terms to suppress intra-societal resistance in each Central American country.

This reinterpretation of the waves of regionalism in Central America became explainable with reference to the underlying security narrative. Overall, I opted for a detailed analysis of what and who emerged as a security threat in the respective examples. What lies underneath this overall claim is the acknowledgment that the specific configuration of the security narrative is important. The rather exceptional configuration throughout the long durée has been a mergence and alignment of external and internal threat perception. When this configuration dominated, regionalism in Central America emerged. The rule, however, was an absence of lasting external threat perceptions and, instead, the prevalence of intra-Central American threat perceptions. When Central Americans feared their fellow citizens and neighbors more than anything else, dissolution of regionalism and fragmentation was the result. In this historical retrospective, one may even differentiate what intra-Central American threat perception means: (1) During the 19th century, intra-Central American threat perception meant mainly anxiety and grievances between elite factions on a rather horizontal level. This eventually was responsible for regional fragmentation and tentative state formation, respectively consolidation. (2) After the great depression of the 1930s, intra-Central American threat perception rather turned inwards and was vertical in terms of increasing fear of popular uprisings and leftist movements. Horizontal threat perception did not completely vanish but rather took a backseat within the security narrative. 


\section{References}

Acuña Ortega, Víctor Hugo. Las républicas agroexportadoras. Sociedad Estatal Quinto Centenario, 1993.

Aguilera Peralta, Gabriel E. "Enfoques históricos sobre la seguridad en Centroamérica." Educar para la Seguridad, edited by Universidad para la Paz, Universidad para la Paz, 2004, pp. 131-63.

Bøås, Morten, et al. "The Weave-World: The Regional Interweaving of Economies, Ideas and Identities." Theories of New Regionalism: A Palgrave Reader, edited by Fredrik Söderbaum and Timothy M. Shaw, Palgrave Macmillan, 2003, pp. 197-210.

Briscoe, C. H. El apoyo del istmo a política nacional de seguridad americana: una realidad o un engaño. Campbell University, 2001, www. hcentroamerica.fcs.ucr.ac.cr/Contenidos/hca/cong/mesas/cong5/docs/bPol1. pdf/.

Brockett, Charles D. Land, Power, and Poverty: Agrarian Transformation and Political Conflict in Central America. Unwin Hyman, 1990.

Bull, Benedicte. "New Regionalism' in Central America." Third World Quarterly, vol. 20, no. 5, 1999, pp. 957-70.

Bulmer-Thomas, Victor. "Economic Development over the Long Run: Central America since 1920." Journal of Latin American Studies, vol. 15, no. 2, 1983, pp. 269-94.

Bulmer-Thomas, Victor. The Political Economy of Central America since 1920. Cambridge University Press, 1987.

Bulmer-Thomas, Victor. "The Central American Common Market: From Closed to Open Regionalism.” World Development, vol. 26, no. 2, 1998, pp. 313-22.

Cable, Vincent. “The 'Football War' and the Central American Common Market." International Affairs (Royal Institute of International Affairs 1944-), vol. 45, no. 4, 1969, pp. 658-71.

Clegern, Wayne M. Origins of Liberal Dictatorship in Central America: Guatemala, 1865-1873. University Press of Colorado, 1994.

Creamer, Winifred. "Mesoamerica as a Concept: An Archaeological View from Central America." Latin American Research Review, vol. 22, no. 1, 1987, pp. 35-62.

Dabène, Olivier. The Politics of Regional Integration in Latin America: Theoretical and Comparative Explorations. Palgrave Macmillan, 2009.

Dolinsky, Gerardo T, and Sarah Stookey. "Debt and Structural Adjustment in Central America." Latin American Perspectives, vol. 17, no. 4, 1990, pp. 76-90. 
Dunkerley, James. The Long War: Dictatorship and Revolution in El Salvador. Verso, 1983.

Dunkerley, James. Power in the Isthmus: A Political History of Modern Central America. Verso, 1988.

Dym, Jordana. From Sovereign Villages to National States: City, State, and Federation in Central America, 1759-1839. University of New Mexico Press, 2006.

Dym, Jordana. “'Our Pueblos, Fractions with No Central Unity’: Municipal Sovereignty in Central America, 1808-1821." The Hispanic American Historical Review, vol. 86, no. 3, 2006, pp. 431-66.

Dym, Jordana. "Central America." Nations and Nationalism: A Global Historical Overview, edited by David H. Kaplan and Guntram Henrik Herb, vol. 1, ABC-CLIO, 2008, pp. 309-22.

Fernández-Shaw, Felix. La integración de Centroamérica. Ediciones Cultura Hispánica, 1965.

Floyd, Troy S. "The Guatemalan Merchants, the Government, and the Provincianos, 1750-1800." The Hispanic American Historical Review, vol. 41, no. 1, 1961, pp. 90-110.

Fonseca, Gautama, and Dante Ramírez. "Los órganos del Tratado General de Integración Economica Centroamericana." Derecho de la Integración, vol. 4, no. 6, 1970, pp. 66-97.

Gleijeses, Piero. “The Agrarian Reform of Jacobo Arbenz." Journal of Latin American Studies, vol. 21, no. 3, 1989, pp. 453-80.

Gleijeses, Piero. Shattered Hope: The Guatemalan Revolution and the United States, 1944-1954. Princeton University Press, 1991.

Gudmundson, Lowell, and Héctor Lindo-Fuentes, editors. Central America, 18211871: Liberalism before Liberal Reform. University of Alabama Press, 1995.

Hall, Carolyn. "América Central Como Region Geografica." Anuario de Estudios Centroamericanos, vol. 11, no. 2, 1985, pp. 5-24.

Handy, Jim. "National Policy, Agrarian Reform, and the Corporate Community during the Guatemalan Revolution, 1944-1954." Comparative Studies in Society and History, vol. 30, no. 4, 1988, pp. 698-724.

Handy, Jim. “The Most Precious Fruit of the Revolution': The Guatemalan Agrarian Reform, 1952-54." The Hispanic American Historical Review, vol. 68 , no. 4, 1988, pp. 675-705.

Handy, Jim. "Insurgency and Counter-Insurgency in Guatemala." Sociology of "Developing Societies": Central America, edited by Jan L. Flora and Edelberto Torres-Rivas, Macmillan, 1989, pp. 112-39. 
Handy, Jim. Revolution in the Countryside: Rural Conflict and Agrarian Reform in Guatemala, 1944-1954. University of North Carolina Press, 1994.

Harper's Weekly. "William Walker and the War in Nicaragua." The Central American Crisis Reader, edited by Robert S. Leiken and Barry M. Rubin, Summit Books, 1987, pp. 73-78.

Hernández, Alcides. La integración de Centroamérica: Desde la federación hasta nuestros días.Ed. DEI - Dep. Ecuménico de Investigaciones, 1994.

Hettne, Björn, and Fredrik Söderbaum. "Theorising the Rise of Regioness." New Regionalism in the Global Political Economy: Theories and Cases, edited by Shaun Breslin et al., Routledge, 2002, pp. 33-47.

Hirschman, Albert O. "The Political Economy of Import-Substituting Industrialization in Latin America." The Quarterly Journal of Economics, vol. 82 , no. 1, 1968, pp. 1-32.

Holden, Robert H. "Securing Central America against Communism: The United States and the Modernization of Surveillance in the Cold War." Journal of Interamerican Studies and World Affairs, vol. 41, no. 1, 1999, pp. 1-30.

Holden, Robert H. Armies without Nations: Public Violence and State Formation in Central America, 1821-1960. Oxford University Press, 2004.

Interiano Portillo, Rodolfo. El modelo de seguridad democrática en Centro América y las amenazas a la seguridad regional. Publigraficas, 2007.

Isacson, Adam. Altered States: Security and Demilitarization in Central America. Center for International Policy, 1997.

Karnes, Thomas L. The Failure of Union: Central America, 1824-1960. University of North Carolina Press, 1961.

Lauria-Santiago, Aldo. An Agrarian Republic: Commercial Agriculture and the Politics of Peasant Communities in El Salvador, 1823-1914. University of Pittsburgh Press, 1999.

Leiken, Robert S., and Barry M. Rubin, editors. The Central American Crisis Reader. Summit Books, 1987.

Lindo-Fuentes, Héctor. "The Economy of Central America: From Bourbon Reforms to Liberal Reforms." Central America, 1821-1871: Liberalism before Liberal Reform, edited by Lowell Gudmundson and Héctor Lindo-Fuentes, University of Alabama Press, 1995.

Loveman, Brian. No Higher Law: American Foreign Policy and the Western Hemisphere since 1776. University of North Carolina Press, 2010.

MacLeod, Murdo J. Spanish Central America: A Socioeconomic History, 15201720, University of Texas Press, 1973. 
Mahoney, James. "Path-Dependent Explanations of Regime Change: Central America in Comparative Perspective." Studies in Comparative International Development, vol. 36, no. 1, 2001, pp. 111-41.

Mahoney, James. "Radical, Reformist and Aborted Liberalism: Origins of National Regimes in Central America." Journal of Latin American Studies, vol. 33, no. 2, 2001, pp. 221-56.

May, Robert E. Manifest Destiny's Underworld: Filibustering in Antebellum America. University of North Carolina Press, 2002.

May, Robert E. The Southern Dream of a Caribbean Empire, 1854-1861. 2nd ed., University Press of Florida, 2002.

Medaglia Gómez, Marco A. "William Walker en Centroamérica." Revista Espiga, vol. 7, no. 14, 2015, pp. 1-8.

Medina-Nicolas, Lucile. "Central American Borders at the Core of the Regional Integration Process." Geopolitics, vol. 12, no. 1, 2007, pp. 78-108.

Nairn, Allen. "Behind the Death Squads." The Progressive, vol. 48, no. 5-1, 1984, pp. 20-29.

Niemann, Michael. A Spatial Approach to Regionalisms in the Global Economy. Palgrave Macmillan, 1999.

Nuhn, Helmut. "Zentralamerika: Kleinstaatlichkeit, ökonomische Integration, politische Konflikte.” Geographische Rundschau, vol. 35, no. 10, 1983, pp. 488-96.

Paige, Jeffery M. Coffee and Power: Revolution and the Rise of Democracy in Central America. Harvard University Press, 1997.

Palmer, Steven. "Central American Union or Guatemalan Republic? The National Question in Liberal Guatemala, 1871-1885.” The Americas, vol. 49, no. 4, 1993, pp. 513-30.

Patch, Robert W. "Imperial Politics and Local Economy in Colonial Central America 1670-1770." Past \& Present, no. 143, 1994, pp. 77-107.

Pinto Soria, Julio C. Centroamérica: de la colonia al estado nacional, 1800-1840. Editorial Universitaria de Guatemala, 1986.

Posada, Marcelo G, and Mario López. "El Salvador 1950-1970: Latifundios, integracion y crisis." Revista de Historia de América, no. 115, 1993, pp. 37-62.

Reeves, Rene. Ladinos with Ladinos, Indians with Indians: Land, Labor, and Regional Ethnic Conflict in the Making of Guatemala. Stanford University Press, 2006.

Reza, Germán A. de la. "How Spanish America Disintegrated: Selected CrossNational Factors." Revista de Historia de América, no. 140, 2009, pp. 9-31. 
Riekenberg, Michael. "Die Rebellion der Montañeses im Südosten Guatemalas (1837/38) und der Machtaufstieg Rafael Carreras."Ibero-Amerikanisches Archiv, vol. 19, no. 1-2, 1993, pp. 37-62.

Riekenberg, Michael. Ethnische Kriege in Lateinamerika im 19. Jahrhundert. Heinz Akad. Verl, 1997.

Roniger, Luis. Transnational Politics in Central America. University Press of Florida, 2011.

Sagastume Gemmell, Marco A."Seguridad democratica y derechos humanos en Centroamerica." Seguridad democrática y derechos humanos en Centroamérica, edited by Edgardo Buitrago Buitrago and Marco A. Sagastume Gemmell, CSUCA, 1998, pp. 25-36.

Sánchez Sánchez, Rafael A. The Politics of Central American Integration. Routledge, 2009.

Saxe-Fernández, John. "El consejo de defensa Centroamericano y la Pax Americana." Cuadernos Americanos, vol. 152, no. 3, 1967, pp. 39-57.

Schmitter, Philippe C. "Central American Integration: Spill-Over, Spill-Around or Encapsulation?." Journal of Common Market Studies, vol. 9, no. 1, 1970, pp. 1-48.

Selser, Gregario. Notas sobre la viabilidad de una "OTAS," la naturaleza del CONDECA y las formas de coproducción arma mentista en A. L. Documento de trabajo (8). Documento de Trabajo de SEPLA, 1978.

Smith, Laun C., Jr. "Central American Defense Council: Some Problems and Achievements." Air University Review, March-Apr. 1969, pp. 19-38.

Söderbaum, Fredrik. Rethinking Regionalism. Palgrave, 2016.

Weaver, Frederick S. Inside the Volcano: The History and Political Economy of Central America. Westview Press, 1994.

Weaver, Frederick S. "Reform and (Counter) Revolution in Post-Independence Guatemala: Liberalism, Conservatism, and Postmodern Controversies." Latin American Perspectives, vol. 26, no. 2, 1999, pp. 129-58.

Williams, Robert G. States and Social Evolution: Coffee and the Rise of National Governments in Central America. University of North Carolina Press, 1994.

Woodward, Ralph L. "Economic and Social Origins of the Guatemalan Political Parties (1773-1823)." The Hispanic American Historical Review, vol. 45, no. 4, 1965, pp. 544-66.

Woodward, Ralph L. Central America: A Nation Divided. 3rd ed., Oxford University Press, 1999.

Wortman, Miles. "Bourbon Reforms in Central America: 1750-1786." The Americas, vol. 32, no. 2, 1975, pp. 222-38. 
Wortman, Miles. "Government Revenue and Economic Trends in Central America, 1787-1819." The Hispanic American Historical Review, vol. 55, no. 2, 1975, pp. 251-86.

Zinecker, Heidrun. Kolumbien und El Salvador im longitudinalen Vergleich: ein kritischer Beitrag zur Transitionsforschung. Nomos, 2007.

Zinecker, Heidrun. Gewalt im Frieden: Formen und Ursachen der Gewaltkriminalität in Zentralamerika. Nomos, 2014. 

Configuring Space: Borders, Frontiers, and the Dialectics of Inclusion and Exclusion 

Josef Raab

\title{
Contestation, Hybridization, Criminalization: US-Mexican Borderland Vistas
}

\begin{abstract}
Ever since the end of the United States' war against Mexico in 1848, the territories along the border between the two nations have been a vibrant, but also a turbulent intercultural space. This chapter examines some discursive and medial constructions of spaces north of the US-Mexican border over the last century and a half. It identifies contestation, hybridization, and criminalization as the three main approaches. Oppositional discourses dominate Mexican American conceptualizations of this space from the folk corridos of the 19th century to present-day claims that "We did not cross the border. The border crossed us." In this respect the chapter addresses various literary texts of the 19th and 20th century as well as Rodolfo F. Acuña's revisionist Occupied America: A History of Chicanos (8th ed., 2014). As to hybridization discourses, I focus on the border image created in John Sayles' 1996 film Lone Star. A third approach designates this border region a lawless space in need of state intervention. This spatialization started with $1850 \mathrm{~s}$ reports on the perils of the Santa Fe Trail and it has been propagated since 2015 by the current US president. Social and political practice as well as discourses in literature, media, academia, and political rhetoric have unsettled this border space with their competing characterizations and agendas.
\end{abstract}

Ever since the end of the United States' war against Mexico in 1848, the territories along the border between the two nations have been a vibrant, but also a turbulent intercultural and transnational space-spanning from the Texas coast of the Gulf of Mexico to the San Diego/Tijuana border region on the Pacific coast. Politics, social interaction, and cultural imaginaries have characterized this almost 2,000 mile-long stretch as a virtually borderless contact zone but also as an increasingly militarized space in which US immigration authorities as well as self-appointed vigilante groups try to prevent undocumented border crossings. With approximately 350 million legal crossings ${ }^{1}$ annually, the US-Mexican border gets crossed more frequently than any other in the world. In recent decades, territories north and south of the border have seen an economic boom fostered by NAFTA but also the rise of violence and crime, drug

1 This is the figure given by Wikipedia for the year 2010 ("Mexico-United States border," https://en.wikipedia.org/wiki/Mexico\%E2\%80\%93United_States_border). 
trafficking, and deaths of undocumented border crossers who fall victim to the desert or to criminals. Gloria Anzaldúa's famous characterization of this border space as "an open wound" speaks to the wide-ranging disenfranchisement of the population of Mexican descent after 1848 and to continuing dynamics of racism and classism (3).

As a transcultural and transnational space, the US-Mexican borderlands remain contested territory. Their spatialization, by which I mean their partition and interpretation, reflects power dynamics and competing interests. Different ethnic groups and political interests, conflicting ideologies and opposing desires for dominance all lay claim to the borderlands. Beyond physical geography, this competition makes the borderlands a relational space with a contested societal and symbolic order. ${ }^{2}$ Christian Wille and Markus Hesse have rightly noted that "spaces are more or less manifestly shaped by power relationships .... These are revealed by examining differentiations, attributions of meaning, hierarchizations and other techniques of the exercise of power that are inherent in spatial constructions" (31). Space is divided and attributed depending on which individual, group, nation, or ideology is in charge or is trying to gain control. On the one hand, spatialization involves the division of physical territory into spheres of domination, on the other, it focuses on the people in a shared space, highlighting the primacy and rights of some and the deficiency or illegality of others. As Doreen Massey points out-based on Henri Lefebvre's notion of space as socially produced-"space presents us with the social in the widest sense: the challenge of our constitutive interrelatedness" (195). Space reflects the interests and maneuvers of those interacting in it as well as the ideologies of those trying to shape it from the outside, becoming the site and object of multiple discourses, narratives, and actions aiming at domination. Massey treats space as "the dimension of multiple trajectories, a simultaneity of stories-so-far" (24). She highlights the interrelatedness of space and time, reminding us that more so than

2 As Christian Wille and Markus Hesse point out, space has been approached variously (a) as a material substance in physical geography, (b) as "a product of relational systems instead of a quasi natural result of terrestrial conditions" (27), a structure for ordering and juxtaposing, and (c) as socially produced, "a manifestation of societal structures" (27). They conclude that the "relational-descriptive" and the "symbolic-interpretative" approaches to space "are often discussed together in space-sensitive studies and, in the context of the border, are usually considered against the foil of a territorial nation-state order. This foil is then frequently employed to serve as an 'underlay' for the social, forming a mosaic of container spaces, which however need to be regarded in relational and symbolic terms" (28). 
physical geography it is spatialization that is changeable. Depending on who is in a position of power at a certain historical moment, the same territory will be spatialized differently over time. Space is thus also an asset which individuals, organizations, and governments seek to appropriate or control, striving for the authority to define and shape it.

Control of Texas, for example, has shifted repeatedly over the centuries. Native American tribes, especially the Comanche, were displaced by Spanish colonizers. The rule of the Spanish crown was challenged when the Mexican colonies declared their independence from Spain in 1810. After the end of the Mexican War of Independence in 1821 "Coahuila y Tejas" became a constituent state of the United Mexican States under the country's 1824 constitution. Except for some remaining indigenous tribes the population of Texas was almost 100 percent Spanish-Mexican for the first quarter of the nineteenth century. But over the following decade immigration from the United States and Europe was encouraged and huge land grants were given to so-called empresarios. As a result, by 1834 only about 20 percent of Texas' population was of Mexican descent. The new non-Mexican majority declared the independence of Texas from Mexico and proclaimed the Republic of Texas in 1836. Meanwhile the United States had been expanding westward and when James Knox Polk became president in 1845 , his administration tried unsuccessfully to buy California from Mexico. In December of that year the United States annexed the Republic of Texas, and Polk was looking for ways to enlarge the annexed territory. While the Mexican government claimed that the southern border of Texas was the Nueces River, Polk and Anglo-Texans maintained that the annexed territory extended all the way to the Rio Grande, 150 miles south of the Nueces River (Gonzales 76). Rather than submitting the issue to international arbitration as proposed by Mexico, Polk stationed US troops in the contested territory and waited for Mexico to declare war, which it did in April 1846 (76). The war, disastrous for Mexico, established a new spatial order. As Manuel G. Gonzales summarizes,

Mexico not only had to surrender the vast lands of California and New Mexico, but it was forced to recognize the humiliating loss of Texas. Altogether, it lost 947,570 square miles of land, almost half of its national territory, though less than 1 percent of its population. ... Mexicans in the conquered territory were given the alternative of packing up and moving south into Mexican territory-an option that only about 2,000 of the 100,000 eligible candidates chose-or remaining in what had become the American Southwest....

The armed conflict occurred for many reasons, but mostly because Americans wanted war, or rather what war would provide. The naked truth remains that Mexico had what its northern neighbor craved-land. (79-81) 
That land, which is now the Southwest of the United States and the US-Mexican borderlands, was spatialized in a new manner as an outcome of the US war with Mexico: New power elites took control, new ideologies (above all that of "Manifest Destiny") rationalized a new spatial and legal order, and Mexicans were dispossessed, cheated, lynched, and disenfranchised.

The spatialization of the US-Mexican borderlands changed over the centuries because of historical developments but also because of new ways of ordering the globe. Walter D. Mignolo reminds us that "America" and the "Western Hemisphere" are "inventions" ("Decolonial" 60). As such, they are subject to different ideologically founded interpretations and spatializations. ${ }^{3}$ The idea of a Global South, which gained prominence in the 1970s, complicates the spatialization of the Americas and creates overlaid borderlines. As Mignolo writes,

there is, on the one hand, South and Central America, and, on the other, North America. In the middle there is the Caribbean, which is also counted as Global South. But that is not all, because there is also the South of the North (e.g., the South of the U.S. ...). The superposition of the Global South over Hemispheric America flags the power differentials in the very same Hemisphere-power differentials that can be accounted for by the history of coloniality from 1500 to the present. ("Decolonial" 61)

The US-Mexican borderlands are also the geographical limits of the Global South and thus a zone of simultaneity, where languages, economic systems, cultural traditions, and diverging effects of coloniality intersect. The result of this intersection can be spatialized as segmentation or as a challenge to borderlines. The latter view is held by the Mexican performance artist Guillermo GómezPeña, who writes:

for me, the border is no longer located at any fixed geopolitical site. I carry the border with me, and I find new borders wherever I go.

I travel across a different America. My America is a continent (not a country) that is not described by the outlines on any of the standard maps.... My America includes different peoples, cities, borders, and nations....

3 Mignolo points out that "both 'America' and 'Western Hemisphere' are not entities but geopolitical ideas to organize the planet; or, if you wish, these are entities configured by an idea constituted by a name and a cartographic image" ("Decolonial" 60). Within the Western Hemisphere, national borderlines were created on the basis of spheres of influence and military strength. These spatialized the continent. But as the acquisition by the United States of almost the northern half of the United Mexican States in 1848 illustrates, the spatialization and its interpretation (ranging from considering borders as contact zones to treating them as demarcation lines) are temporary and subject to who is in power. 
When I am on the East Coast of the United States, I am also in Europe, Africa, and the Caribbean. There, I like to visit Nuyo Rico, Cuba York, and other micro-republics. When I return to the U.S. Southwest, I am suddenly back in Mexamerica, a vast conceptual nation that also includes the northern states of Mexico, and overlaps with various Indian nations. When I visit Los Angeles or San Francisco, I am at the same time in Latin America and Asia. Los Angeles, like Mexico City, Tijuana, Miami, Chicago, and New York, is practically a hybrid nation/city in itself. (5-6)

To be sure, this is the view of the privileged artist-traveler with proper travel documents, not that of the individual struggling with physical and metaphorical borderlines.

As these views of historian Manuel G. Gonzales, cultural critic Walter D. Mignolo, and performance artist Guillermo Gómez-Peña illustrate, spatialization remains to a large degree in the eyes of the beholder. Depending on an individual's or a group's own position, the same physical space will be interpreted differently in reflection of their ideologies and interests. This essay will focus on the discursive and medial construction of spaces north of the US-Mexican border over the last 170 years. The main approaches can be characterized as contestation, hybridization, and criminalization. These three different mechanics of spatialization should not be seen as a sequence but as three ongoing and parallel borderland vistas. Applying Henri Lefebvre's notion of space as socially constructed, we can consider the 1848 US takeover of Mexican lands from Texas to California under the Treaty of Guadalupe Hidalgo and the resistance of the Mexican population that remained in those areas as the historical basis of a contested border space. Oppositional discourses dominate Mexican American conceptualizations of this space from the folk corridos of the 19th century to present-day claims that "We did not cross the border. The border crossed us." In this respect I will address various texts of the 19th and 20th century, leading up to Rodolfo F. Acuña's revisionist Occupied America: A History of Chicanos, which was first published as a textbook in the context of the Chicano movement in 1972 and which is now in its eighth edition (2014). As to hybridization discourses of the US-Mexico border space, I will focus on the border image created in John Sayles' 1996 film Lone Star, which exemplifies the permanence of transborder interconnections and the artificiality of attempts at trying to keep different cultural traditions and different ethnic groups apart. A third approach designates this border region a lawless space in need of state intervention. This spatialization started with the perils associated with the Santa Fe Trail and the Old Spanish Trail as well as justifications of the Texas Rangers' actions against the Mexican population from 1848 onward, and it has been propagated since 2015 by the current US president. These three rivaling 
discourses of spatialization illustrate the competition for discursive authority and the range of border space imaginaries.

The dominance of Anglo elites which the US victory had brought to power in 1848 was challenged in numerous oppositional discourses by the Mexican newspapers in the newly annexed US Southwest, in local political election campaigns, and in literature. María Amparo Ruiz, born in Baja California, and married at age 16 to Anglo officer Henry S. Burton of the winning US Army in 1848, is considered the first Mexican American author to publish in English. In 1853 the couple bought a ranch near San Diego, California, on which they lived only part-time because of Burton's deployment to the East Coast and his service in the American Civil War. After the death of her husband in 1869, María Amparo Ruiz de Burton returned to the Southern California ranch to find much of it occupied by squatters who claimed the land as their own. This process had been made possible by the California Land Act of 1851, which set up a commission appointed by the US president in order to "ascertain and settle the private land claims in the State of California." Section 8 of that act stipulates that "each and every person claiming lands in California by virtue of any right or title derived from the Spanish or Mexican government shall present the same to the said commissioners [who will] decide upon the validity of the said claim" (United States, Congress 632), adding that the commission's decision can be challenged in court. While litigation was ongoing, property rights were not respected and Mexican land grants were considered public domain and available for resettlement. So Ruiz de Burton spent the last 26 years of her life-until her death in 1895-in court proceedings trying to have the land title to her ranch validated. In her novel The Squatter and the Don (1885), she used her autobiographical experiences as the background for a plot of a land-owning Californio family struggling with Anglo squatters and land speculators contesting their land titles and claiming part of their ranch. In the novel, the US district courts and the California Land Act make the dispossession of the rightful Mexican owners legal. As Ruiz de Burton writes,

All would be done "according to law" and in this easy way more land was taken from its legitimate owner.

This certainly was a more simple way of appropriating the property of "the conquered" than in the days of Alaric or Hannibal.

There would have been bloodshed then. Now tears only flowed; silent tears of helpless discouragement; of a presentiment of impending desolation. (73-74; emphasis in the original)

This historical romance illustrates its author's view that greed, corruption, and a lack of humanist values are aided by the lawmakers and courts in destroying the old order and disregarding property rights. The "legitimate owner[s]" are dispossessed 
in a newly spatialized Southern California reigned by railroad magnates and land speculators and infested by profiteering squatters. To Ruiz de Burton, who had been born into a wealthy family in Baja California and who had married into Anglo prestige (being close friends, for example, with Mary Todd Lincoln), it was an insult that in her court struggles her Mexican heritage outweighed her class prestige. José F. Aranda therefore commented that the life and work of Ruiz de Burton reveal "an individual willing to wage a rhetorical war on her conquerors but also anxious to reassume the privileges of a colonialist" (554).

But it was not only the privileged classes that suffered great losses as a consequence of the US takeover of the northern half of Mexico in 1848 and that contested Anglo domination. Some dispossessed and disenfranchised Mexicans resorted to banditry and other forms of resistance, for which they were pursued by the military rule under which the newly acquired territories had been put and by self-appointed so-called "vigilance committees." Between 1850 and 1870, mobs carried out approximately 35 lynchings of Mexicans in Los Angeles alone. Bandits and resistance fighters were celebrated in corridos, i.e., folk ballads, from California to Texas. The classic "Corrido de Gregorio Cortez," thoroughly researched by Américo Paredes, tells of a border space dominated by an unjust Anglo power wielded against a heroic Mexican. As Paredes points out, "the first Border Mexican to 'fight for his right with his pistol in his hand" "was Juan Nepomuceno Cortina, who started a revolt in the Lower Rio Grande Valley in 1859 (134). He and other resistance fighters in the US-Mexican borderlands became the subjects of corridos between the 1830s and the 1930s. According to Paredes, "[ $\mathrm{t}]$ he corrido of border conflict assumes its most characteristic form when its subject deals with the conflict between Border Mexican and AngloTexan, with the Mexican-outnumbered and pistol in hand-defending his 'right' against the rinches. ... [B] order conflict dominated Border balladry for almost a century" (147-48). It is important to note that the hero is not a robber or smuggler but "the peaceful man who defends his right" (Paredes 150).

Based on an incident that occurred in 1901, "El Corrido de Gregorio Cortez" contests Mexico-Texan disenfranchisement, Anglo domination, and the alleged superiority of the Texas Rangers, presenting them as fearful, unskilled, and cowardly. As the lyrics in "Variant X" state in Paredes' English translation, after the killing of a sheriff in Karnes County, Gregorio Cortez is identified as the perpetrator:

Now they have outlawed Cortez,

Throughout the whole state;

Let him be taken, dead or alive;

He has killed several men. 


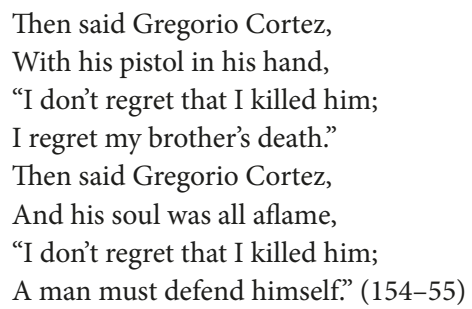

It is only because other Mexicans are killed by the Texas Rangers who pursue him that Gregorio Cortez surrenders-heroically and on his own terms. By challenging the instrument of Anglo domination (presenting the Texas Rangers as scared, weak, and unjust) this corrido also contests the appropriation of the border space by Anglo settlers and speculators aided by courts and law enforcement agencies. It opposes to the prevailing alter-image of the subaltern "greaser" or "peón" that of the accomplished, noble Mexican outlaw whom not even 300 Texas Rangers can catch but who ultimately turns himself in so that others will not be punished for his deed. Although this contestation is based on a specific historical incident, it expresses the long-lasting feeling of Mexican American dispossession and unjust treatment under Anglo rule and it opposes the prevailing spatialization of the US-Mexican borderlands.

Out of this feeling of having been robbed of their homeland came the nationalist tendencies of the Chicano movement, which claimed the Southwest of the United States as "Aztlán," the space that should rightfully belong to a Chicano nation, the descendants of Aztecs and Spanish colonizers. The 1969 "Plan Espiritual de Aztlán" contests the present order, demanding Chicano "social, economic, cultural and political independence" in the territory acquired by the United States after its war against Mexico in 1848. The document states:

In the spirit of a new people that is conscious not only of its proud historical heritage but also of the brutal "gringo" invasion of our territories, we, the Chicano inhabitants and civilizers of the northern land of Aztlán from whence came our forefathers, reclaiming the land of their birth and consecrating the determination of our people of the sun, declare that the call of our blood is our power, our responsibility, and our inevitable destiny.

We are free and sovereign to determine those tasks which are justly called for by our house, our land, the sweat of our brows, and by our hearts. Aztlán belongs to those who plant the seeds, water the fields, and gather the crops and not to the foreign Europeans. We do not recognize capricious frontiers on the bronze continents. (1)

The "bronze continents" which this manifesto proclaims are a transborder space that extends from the US Southwest into Mexico and beyond. Their conception 
relies on ethnic essentialism, they become the territory of "La Raza de Bronze," which European Americans appropriated. The formulation "reclaiming the land" reveals the activists' spatialization: the territories claimed by the United States in 1848 and controlled by Anglo power elites since then are to be recast as Aztlán and are to become the homeland of "a new people" that resists "the brutal 'gringo' invasion of our territories." This "invasion" is seen as having geographical, economic, cultural, and political ramifications: "Our struggle then must be for the control of our barrios, campos, pueblos, lands, our economy, our culture, and our political life" (2). The Southwest of the United States is claimed as the territory of a mythical Aztlán and of a future Chicano self-rule.

The question of what is to be considered "our territory" is also behind one of the best-known murals connected to the Chicano movement: "We Are Not a Minority," painted on the back of a home in a housing project on Olympic Boulevard in East Los Angeles in 1978 by a group of artists who called themselves El Congreso de Artistas Cósmicos de las Américas de San Diego (Fig. 5).

Using the calligraphy of the US Constitution in "We are," the mural presents itself as a foundational document. The "NOT" in capital letters and in red announces resistance to the dominant political discourse, as does the image of Che Guevara. The mural insists on the primacy of Aztec culture-symbolized through the pyramid shape of the "A"-over Anglo America. Urgency is conveyed through the two exclamation marks, the eyes of the Che Guevara figure on the onlooker, and the pointing finger (reminiscent of the US Army recruitment poster "I Want You."). These attributes defy the narrative of the power elites, according to which Latinas/os in the United States are an inferior minority in an Anglo-dominated space.

Out of this same oppositional attitude comes also Rodolfo F. Acuña's revisionist history textbook Occupied America: A History of Chicanos, first published in 1972, and now a classic text in Chicana/o Studies. In the book's first edition Acuña wrote:

Incomplete or biased analyses by historians have perpetuated factual errors and created myths. The Anglo-American public has believed and encouraged the historian's and the social commentator's portrayal of Mexicans as 'the enemy.' The tragedy is that the myths have degraded the Mexican people-not only in the eyes of those who feel superior, but also in their own eyes. (xv)

Acuña uses the leitmotif of Mexican Americans living in an "internal colony" in the United States and he contests earlier racialized and racist accounts, which he calls "the errors of Euro-American historians" (xv, xvi). Space plays a central role in this endeavor, as evidenced by the use of "occupied" in the book's 


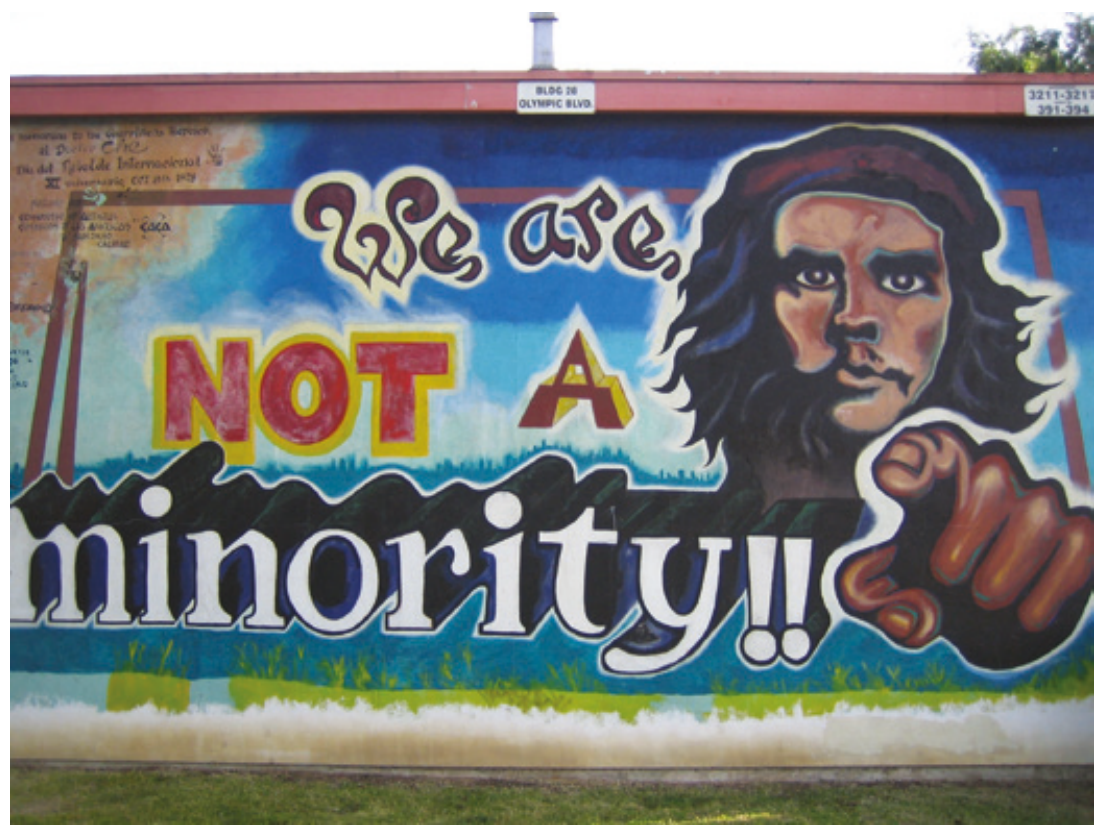

Fig. 5: "We Are Not a Minority" Mural by El Congreso de Artistas Cósmicos de las Américas de San Diego, East Los Angeles, 1978. Source: Photograph (c) Josef Raab.

title. Having originally intended to "explain historical events leading up to the 1970 Chicano Moratorium and the murder of Rubén Salazar, a former Los Angeles Times reporter and news director for the Spanish language television station KMEX in Los Angeles," Acuña gradually expanded the book to include chapters ranging from preconquest indigenous civilizations in Mesoamerica to "Mexican Americans and 9/11" and events up to the reelection of Barack Obama in 2012 (xv). The book's pervasive theme is the struggle of Chicanas/os and their ancestors in an occupied space.

Acuña first presents a proud heritage going back to "The Corn People" in the "Valley of Mexico" and other indigenous civilizations that fell prey to Spanish colonizers and then shifts to the "legacy of hate" (ch. 3) responsible for the US war against Mexico, a war of "unwarranted aggression" (46) that ended with a peace treaty which Acuña calls a "deception" (52). As Anglos assumed power and appropriated land, writes Acuña, racism and segregation were common, the testimony of Mexicans was not recognized in courts. Subsequently, when the 
industrialization of Los Angeles took off in the late 19th century, "[d]iscrimination toward Mexicans in the wage-labor market increased; a dual-wage system persisted, with Mexicans and Chinese paid less compared to Euro-Americans" (149). The history of abuse, as Acuña tells it, continues into the twentieth century, for example with Mexican American homeowners in Chávez Ravine north of downtown Los Angeles being evicted in 1957 so that the land could be used to build Dodger Stadium (288).

For the 21st century, Acuña sees progress in California, but a dire situation in Arizona, where in 2012 Arizona Senate Bill (SB) 1070 introduced antiimmigration measures and Arizona House Bill (HB) 2281 "made the teaching of ethnic studies and Mexican [American] studies in particular unlawful. The rationale was the securing of the border and the allegation that Mexican American Studies divided races and was subversive" (410). Acuña contests this domination of the state of Arizona by white nativists, speaking of the "corporate predators" behind the racist actions and labeling the state and its Latina/o population as being "under siege":

For the past five years Arizona has been a nightmare, taken over by corporate predators such as the Koch brothers and ALEC-the American Legislative Exchange Councilthat have moved into Arizona. The latter controls over 50 state legislators and has written legislation such as SB 1070. It is in league with the prison industry that has spearheaded the privatization of prisons and reaped a bonanza from incarcerating undocumented and other Latinos. The infamous Koch brothers have funded the Tea Party and agitated racial hatred within the state. In the process these predators seized control of the Republican Party, and silenced Democrats who are prominent in the ranks of the Blue Dogs. In this environment Mexicans were under siege, especially Arizona's highly touted Mexican American Studies Program, which the predators labeled subversive, unpatriotic and racially divisive based on no proof other than state Superintendent of Schools John Huppenthal and state Attorney General Tom Horne saying it was. Very expensive studies conducted by the state and federal government proved otherwise. (411)

The triple use of "predators" in one and the same paragraph contests the state's official narrative of doing away with divisiveness in education and exposes the profitability of promoting ethnic divides and a fear of the population of Mexican descent as well as of legal and illegal Latina/o immigration. While "the prison industry" and conservative lawmakers interpret the state as being threatened by its Latino residents, Acuna presents the counter-narrative of Arizona "under siege" by powers that "agitated racial hatred."

The spatialization discourse uniting the above sources is marked by the misappropriation of land by the United States and by Anglos, a legal and spatial ousting of Mexicans and Mexican Americans, and a contestation of these processes in 
fiction, song, political activism, visual art, and scholarship. Assuming a stark opposition between Mexicans and non-Mexicans, the approach to space is ethnically determined: the underlying assumption, that there are Mexican spaces which have come under non-Mexican control through the conquest and especially since 1848 and which Mexican American voices now reclaim, protests white hegemony.

A different conceptualization of the borderlands space north of the US-Mexican frontier is almost as old as the contestation approach, though. It is an approach that highlights interculturalism and cultural hybridity. In María Amparo Ruiz de Burton's The Squatter and the Don, for example, there is-apart from the indictment of lawless squatters and Anglo courts-a plea for the righteous among the Mexicans as well as among the Anglos to form an alliance, as exemplified by the prospective union of the son of an Anglo squatter turned settler with the daughter of the Mexican don who is in danger of losing his estate to profiteers. An intra-ethnic mediation between the cultural traditions of Catholicism vs. curanderismo, ranching vs. farming, crime vs. righteousness, and life in the llano vs. life outside of it appears in Rudolfo A. Anaya's novel Bless Me, Ultima (1972), set in a New Mexico border space of competing and conflicting interests and cultural practices. A much larger cast of diverse characters-most of them Mexican American, some Mexican, some Anglo-appears in Rolando Hinojosa's novel The Valley (1983). ${ }^{4}$ In a little over a hundred pages we meet almost as many characters, all with their distinctive experiences and all occupying distinct positions in a predominantly Latino community on the north side of the Lower Rio Grande Valley. They appear as members of a hybrid transborder community marked by contradictory impulses but still getting along by and large. Anaya's New Mexico and Hinojosa's Texas are spatialized as hybrid sites for multiple traditions, ideologies, and cultural practices; individuals and groups experience lifeworlds marked by intercultural contact, exchange, and competition.

While Anaya and Hinojosa attach the "inter" of interculturalism to the interaction of different individuals and groups, each representing one predominant feature or tradition, Gloria Anzaldúa's classic Borderlands/La Frontera: The New Mestiza (1987) takes a more radical approach. This multi-genre book locates the "inter" inside one and the same individual, whom the subtitle calls "the new

4 Hinojosa published Estampas del valle y otras obras in 1973. Ten years later The Valley came out. The latter is less a translation than a new rendering of the community of fictional Belken County in the Lower Rio Grande Valley of Texas. Compared to Estampas, some scenes and characters are added or changed in the English version of this hybrid narrative told in vignettes. 
mestiza." This individual, to Anzaldúa, is a crossroads or a bridge, a meeting place of different identity markers; she is in a constant dialogue with aspects of herself and with others. The "new mestiza" consciousness involves an openness toward "racial, ideological, cultural and biological cross-pollinization" and the ability to live in more than one culture, i.e. to manage and thrive in an intercultural space like the US-Mexican borderlands (77). As Anzaldúa writes,

The new mestiza copes by developing a tolerance for contradictions, a tolerance for ambiguity. She learns to be an Indian in Mexican culture, to be Mexican from an Anglo point of view. She learns to juggle cultures. She has a plural personality.... Not only does she sustain contradictions, she turns the ambivalence into something else. (79)

The "new mestiza" recognizes the hybridity of her heritage and identity and she lives this hybridity with pride. Her "plural personality" then puts her in a position to mediate between cultures.

As Anzaldúa puts it in the poem "To live in the Borderlands means you," one of the final texts in her book:

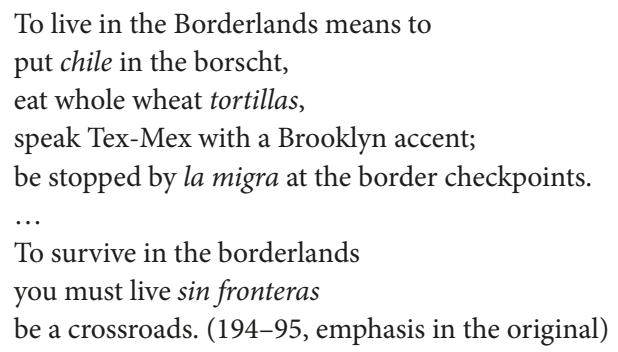

Anzaldúa's inspired multi-genre work militates against (neo-)colonial discourse, which Homi Bhabha defines as "a form of discourse crucial to the binding of a range of differences and discriminations that inform the discursive and political practices of racial and cultural hierarchization" (67). While hierarchies and divisions make the borderlands in Anzaldúa's view "an open wound" (3), she believes that an openness to contradictions, a tolerance for ambiguity, and the willingness to be a crossroads will move the borderlands beyond dichotomies and recognize them as a hybrid space.

Close to a decade after the publication of Anzaldúa's book, in 1996, the film Lone Star, written and directed by Anglo filmmaker John Sayles, explored ethnic diversity in the fictional Texas border town of Frontera. Flashbacks integrate the conflicts and allegiances of the past into those of the present, illustrating the timelessness of attempts to keep different ethnic groups separate as well as the futility and fictitiousness of that endeavor. A white male 
soldier proposes to a black female soldier, a young man explores his Seminole heritage, combining Native American and black ancestry, an Anglo sheriff discovers that his dead father had had a long-term love affair with a Mexican woman, breaking up the son's romance with the woman's daughter because the two are half-siblings. The film illustrates the violence and abuse that have emanated over decades from attempts at spatializing Texas as a compartmentalized territory rather than a place in which social interaction has long produced a hybrid space. Those who benefited from this spatialization are afraid of a future without it, as for example an Anglo-Texan bartender, who tells the protagonist, Sheriff Sam Deeds:

We are in a state of crisis. The lines of demarcation are getting fuzzy. To run a successful civilization you have got to have your lines of demarcation between right and wrong, between this one and that one. Your daddy understood that. He was a ..., what do you call it, a referee in this damn menudo we got down here. He understood how most folks don't want their salt and sugar in the same jar. ... You're the last white sheriff this town's gonna see. Hollis retires next year, Jorge Guera's gonna take over [as mayor]. This is it, right here, Sam. This bar is the last stand. Se habla American, God damn it.

His views are steeped in a past of segregation and they reflect the fears (among the hitherto privileged) of a future of hybridization.

Similarly an Anglo history teacher at high school accuses her Mexican American colleague Pilar (Sam's girlfriend of two decades earlier and also his current love interest) of teaching Texas history with "everything switched around." Another Anglo colleague adds that their own version is "history," whereas other versions that are more critical of the role of Anglos in the history of Texas are "propaganda." He quips: "Now I'm certain they got their own account of the Alamo on the other side, but we're not on the other side," i.e., in Mexico. Pilar, on the other hand, explains: "I've only been trying to get across part of the complexity of our situation down here: cultures coming together in both negative and positive ways." Underlining the film's plea for inter-ethnic cooperation, her

5 Her attitude of feeling called upon to defend institutionalized practices reemerges eight years later in Samuel P. Huntington's Who Are We?: The Challenges to America's National Identity (2004). In view of the growing use of Spanish in US politics Huntington warned his readers that "If this trend continues, the cultural division between Hispanics and Anglos will replace the racial division between blacks and whites as the most serious cleavage in American society. A bifurcated America with two languages and two cultures will be fundamentally different from the America with one language and one core Anglo-Protestant culture that has existed for over three centuries" (324). 
position is seconded by an Anglo teacher who defends the goal "to present a more complete picture." This is the picture of a hybrid space of cross-cultural interaction, which extends into Mexico and in which past events explain many spatializations of the present.

The past forces itself upon the present through a skeleton found in the desert, which brings up the question whether this might be the remains of the shady Sheriff Charlie Wade, who had disappeared in 1957. In his attempts to find out more about Wade, his father (Buddy Deeds, who succeeded Wade as sheriff), and Pilar's alleged father (Eladio Cruz), Sheriff Sam Deeds, crosses the international border into Mexico. He takes off his sheriff's badge and uses his private car, which signifies that in Mexico he does not have the sheriff privileges he enjoys in the United States and that his quest is also a matter of private interest. Sam goes to see a man who lived and worked in the United States for about fifteen years and who now owns several tire businesses in Mexico. He inquires about Eladio Cruz, a Texas-Mexican killed by Charlie Wade some forty years earlier, as he was illegally transporting a group of men from Mexico to Texas, undermining Wade's own control of illegal border crossings.

The entry into Mexico is easy for Sam Deeds: there is just one bridge to cross. Once Sam has driven across that bridge, the film's visual and auditory elements convey exuberance and squalor. The exuberance is expressed through the upbeat ad that we hear for a tire business as well as through the colorful street that is presented in a moving shot, as the camera glides along with Sam's car. But the fenced, trash-strewn lot and the maze of power lines create an image of backwardness and messiness that is in contrast to the clean town of Frontera north of the border that Sam has just left. Despite these visual and auditory markers that spatialize Mexico and the United States differently, the conversation between Sam and the Mexican garage owner he has come to question illustrates the artificiality of borders.

As the two men talk, "el rey de las llantas," the king of tires, draws a line in the dirt with a coke bottle (Fig. 6) and asks Sam to step across it, illustrating in this manner that Sam's privileges as a sheriff do not extend across the international borderline. But then the garage owner explains how man-made borderlines are unnatural and how they facilitate abuse. He tells Sam:

A bird flying south, do you think he sees this line? Rattlesnake, ... whatever you got, do you think half way across that line they start thinking different? Why should a man? ... My government can go fuck itself and so can yours. I'm talking about people here, men. Mi amigo, Eladio Cruz is giving some friends of his a lift one day in the back of his camion, but because they are on one side of this invisible line and not the other they got to hide in the back como criminales. 


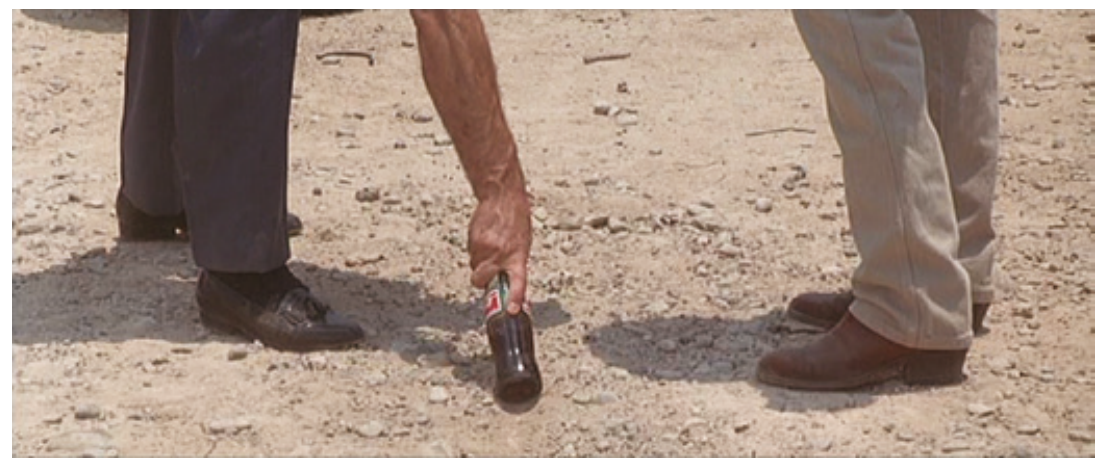

Fig. 6: Screenshot from Lone Star (1996). The "King of Tires" Drawing a Line in the Dirt (01:11:55).

The international border is an "invisible line" when it comes to interactions and cultural practices, but it is a demarcation line when it comes to authority. Sam has no authority in Mexico and Eladio has no authority when Charlie Wade stops and kills him on the US side of the border. Governments, from their dominant position, decide which borders they wish to enforce; they make it possible for power elites (like the corrupt Sheriff Charlie Wade) and criminals to use their control of the border space as a business model, demanding bribes and securing their position through violence. The scene implies, however, that for the common people the border is an unnatural obstacle that exposes them to abuse and exploitation. That the film switches in this scene without any cuts but just through a move of the camera from the present to the past and back to the present and from the Mexican side of the border to the US side conveys the entanglement that characterizes the borderlands space: the past determines the present, and events and conversations on one side of the border influence and reflect what occurs on the other. There are no clear dividing lines, and it is impossible to keep the two sides of the border isolated from one another. While the demarcation line serves governments and profiteers by conferring authority, it oppresses the common people.

Ultimately though, the oppressive forces of separation are overcome in Lone Star. In the film's final scene Sam and Pilar, the daughter of an Americanized Mexican woman who owns a café in town and the person whose romance with Sam was ended by Sam's father at that site 23 years earlier, meet at an abandoned drive-in movie theater. Sam informs Pilar that Eladio Cruz cannot have been her father because he died a year and a half before she was born. He shows her 
a photo of his father with Pilar's mother as lovers, and they figure out that they have the same father. While "Remember the Alamo" had been the battle cry and justification for those who want separate spheres for different ethnic groups and people from different nations, Sam and his half-sister agree to "forget the Alamo," the last words spoken in the film. ${ }^{6}$ Since the Alamo is the symbol of division and conflict, the film conceives of an intercultural South Texas that "start[s] from scratch," as Pilar suggests to Sam. The hope is that the divisiveness of the past will give way to an acknowledgment and appreciation of hybridization. The "Lone Star" state is to be re-spatialized as overcoming old wounds and as accepting the new realities of changed demographics and of Latinas/os in positions of authority. Texas is to become Tex-Mex rather than remaining "lone." Throughout Lone Star, John Sayles tears down clear and easy distinctions. ${ }^{7}$ Borderlines between different ethnic backgrounds and divisions between nations are shown to be artificial and harmful constructs rather than manifestations of a basic difference. The film challenges the validity of borders and stages many instances of border crossings and of movements beyond borders. In this way it re-spatializes Texas as a border state not of "demarcation" but of "cultures coming together in both negative and positive ways."

The hybrid spatialization that Lone Star proposes comes vividly to life, for example in Sandra Cisneros's coming-of-age novel Caramelo (2002) and in Salvador Plascencia's experimental novel The People of Paper (2005). Cisneros presents a transnational tale of family trips between Chicago and Mexico City, with the cultural environments of both locations contributing to the formation

6 Walter D. Mignolo would call the decision to forget the divisive context of the Alamo a "disruption of dichotomies" (Local 85). He labels this approach "border thinking," which he characterizes as "thinking from dichotomous concepts rather than ordering the world in dichotomies" (85, emphasis in the original). Mignolo further explains that "border thinking structures itself on a double consciousness, a double critique operating on the imaginary of the modern/colonial world system, of modernity/ coloniality" (87).

7 By contrast, in 2004 Samuel P. Huntington warned his readers of what he considered trends that challenged US national identity. Among them he named "the slow blurring of racial distinctions and the fading salience of racial identities" as well as "the growing numbers and influence of the Hispanic community and the trend toward a bilingual, bicultural America." He cautioned that "[u]nder some circumstances, these trends could provoke a nativist reaction, sharp polarization, and traumatic cleavages among Americans" (295). While Lone Star presents this "nativist reaction" as fading, toward the end of Barack Obama's presidency the populist and divisive approach of Donald Trump made Huntington's vision come true. 
of the girl protagonist, who eventually settles in the hybrid transborder space of San Antonio, Texas. Plascencia's novel, in the mode of magical realism and postmodern metafiction, conceives of an imaginary borderless space of the Americas, comprising especially Baja and Alta California, a space of various traditions and ambitions that are superimposed.

Thinking in dichotomies and contrasts implies hierarchies, which these texts seek to overcome by imagining flows and interlacing rather than separateness and supremacy. Walter D. Mignolo believes that

[d]ouble consciousness, double critique, an other tongue, an other thinking, new mestiza consciousness, Creolization, transculturation, and culture of transience become the needed categories to undo the subalternization of knowledge and to look for ways of thinking beyond the categories of Western thought from metaphysics to philosophy to science. (Local 326)

Rather than thinking in terms of either/or, border thinking and hybrid spatializations are aware of the dichotomies but are not limited by them.

Apart from the borderlands imaginaries of a contested space and of a hybrid space, the third approach that has been prominent for over a century and a half is that of criminalizing this space. In the 19th century, accounts of settlers and traders taking the Santa Fe Trail (from Missouri to New Mexico) and the Old Spanish Trail (from New Mexico to Southern California) are replete with stories of lawlessness and the rule of the gun. Los Angeles, the end point of the Old Spanish Trail, was infamous for its murder rate in the mid-nineteenth century. As John Mack Faragher reports:

Angelenos were agitated and fearful, and for good reason. The pueblo was one of the most violent towns in America. "Los Angeles is a terrible place for murders," declared the Daily Alta California of San Francisco. "Scarcely a steamer arrives that does not bring an account of one or two." In the five years following California statehood in 1850, Los Angeles County, with some six thousand residents, suffered more than a hundred felonious homicides, twenty-seven of them in 1854 alone. That amounted to a murder rate fifty times greater than New York City .... For every violent death in frontier Los Angeles there were scores of assaults, batterings, rapes, and other acts of brutality.... In the absence of state-sanctioned justice, vigilance committees and lynch mobs hanged at least a dozen suspected offenders. Most violent crime went unpunished. (4)

Faragher quotes John A. Lewis, founding editor of the Star, who was struck in 1853 by the contrast between an edenic landscape and climate and the city's violence:

There is no country where nature is more lavish of her exuberant fullness; and yet, with all our natural beauties and advantages, there is no country where human life is of so 
little account. Men hack one another to pieces with pistols and other cutlery as if God's image were of no more worth than the life of one of the two or three thousand ownerless dogs that prowl about our streets and make night hideous. (9)

This imaginary was taken up by countless westerns with gunslingers, vigilantes, and greasy, unshaven, and unwashed Mexican bandidos terrorizing the American Southwest. It was continued, for example with Orson Welles's film noir Touch of Evil (1958), with the Speedy Gonzalez comics, with Cormac McCarthy's border trilogy, consisting of All the Pretty Horses (1992), The Crossing (1994), and Cities of the Plain (1998) and with Ana Castillo's account of gang life, people smuggling, and drug-related murder in The Guardians (2007). Like Castillo's novel, the TV series Breaking Bad (AMC, 2008-13) locates its imaginary of the borderlands as the site of crime in New Mexico. In Breaking Bad cross-border drug trafficking and violence occur under the veneer of middle-class respectability as the Anglo chemistry teacher Walter White turns to the production of crystallized methamphetamine in the desert north of the border.

Increasingly, Mexico and Latin America play a more central role in the criminalization of the US-Mexican borderlands. In 2004, Samuel P. Huntington criticized Mexican government policies that encouraged emigration to the United States and remittances to Mexico. ${ }^{8}$ Huntington accused the Mexican government of an attitude, according to which "Mexico ... should not try to solve its problems; it should export them" (317). He called the result "an illegal demographic invasion" of the United States, criminalizing migrants (318).

Media reports of drug wars and gang wars spilling over from Mexico into the US Southwest further contributed to spatializing the borderlands as crimeinfested. Toward the end of Barack Obama's first presidency, Lusk, Staudt, and Moya wrote in their assessment of the US-Mexico border region:

The current conception of the US-Mexico border is greatly affected by the explosion of drug-related violence in Mexico, including homicide, kidnapping, and gang warfare. And, even though America's power has been overextended by a war on two fronts, Mexico has increasingly been seen not just as a neighbor with an emigration problem but also as a potentially "failed state." With foreign and defense policy vastly overstretched to extend a decade-long war in Afghanistan and Iraq, America's attention has been turned to Mexico.

Since $9 / 11$, the once relatively porous border has been hardened and militarized across its length. (13)

8 As Mexican president Ernesto Zedillo said in the 1990s, "the Mexican nation extends beyond the territory enclosed by its borders" (qtd. in Huntington 279). 
In addition to illegal immigration, they continue, drug wars have become the main "social construction or 'story' that typifies public perception about the border" (17). Therefore the US-Mexican borderlands have been considered since 9/11 largely as an issue of US national security. In the public imagination, write Lusk, Stadt, and Moya, "[a] vibrant trade zone that is situated in a uniquely interactive binational and bicultural setting has ... been turned into a region scourged by narco-wars, rampant crime, and instability" (19).

While such discourses criminalize the space of the borderlands, recent rhetoric by Donald Trump criminalizes specifically Mexicans and other Latinas/os in that space. When he announced on June 16, 2015 that he would run for the presidency, Trump said: "When Mexico sends its people, they're not sending their best. ... They're sending people that have lots of problems, and they're bringing those problems with us [sic!]. They're bringing drugs. They're bringing crime. They're rapists. And some, I assume, are good people" (Lee). After much criticism, Trump defended himself on July 5, saying in reference to the US-Mexican border that "tremendous crime is coming across. Everybody knows that's true. And it's happening all the time" (Lee). While Rodolfo Acuña had characterized the borderlands as being illegally "occupied" by Anglo America, Trump conceives of them as being under siege by transborder crime committed by "Mexicans."

On January 25, 2017, once he had been installed as US President, Donald Trump accordingly issued Executive Order 13767, which is called "Border Security and Immigration Enforcement Improvements." The document allegedly seeks "to ensure the safety and territorial integrity of the United States as well as to ensure that the Nation's immigration laws are faithfully executed" (United States, Executive Office 8793). It thus assumes that the US-Mexican borderlands are a territory in which safety and lawfulness are endangered by undocumented migrants crossing the border into the United States. Although The Washington Post's fact check contradicts that assumption (Lee), section 1 of the order maintains what we could call in the Trump administration's parlance the "alternative fact" that "[a]liens who illegally enter the United States without inspection or admission present a significant threat to national security and public safety." It goes on to criminalize the borderlands as a space that is in the hands of drug cartels and people smugglers: "Transnational criminal organizations operate sophisticated drug- and human-trafficking networks and smuggling operations on both sides of the southern border, contributing to a significant increase in violent crime and United States deaths from dangerous drugs." There is a sense here that the borderlands that had been captured in 1848 now need to be recaptured and reintegrated into the United States. Toward this end, the main provision of the order is therefore "the immediate construction of 
a physical wall on the southern border, monitored and supported by adequate personnel so as to prevent illegal immigration, drug and human trafficking, and acts of terrorism." Linking the borderlands not only to crime but also to terrorism ups the ante. According to the executive order, the border wall will make it possible for state authorities to "achieve complete operational control of the southern border." This formulation implies that the borderlands are currently out of control, a space apart. People crossing from or through Mexico into the United States are criminalized and blamed for an alleged state of emergency.

At the signing of the executive order at the Department of Homeland Security, Trump explained in his typical simplifying and repetitive manner: "We are going to get the bad ones out-the criminals and the drug dealers and gangs and gang members. The day is over when they can stay in our country and wreak havoc. We are going to get them out, and we are going to get them out fast" (Davis). $\mathrm{He}$ implies a need for a sort of 'cleanup' that would restore respect for the nation's laws and borders and convert a crime-infested space back into a place where law and order rule. On different occasions he used the same approach and action plan when referring to inner cities in the United States. In the Trump imagination a border wall would close the Southwest off from transborder crime and would make it easier to rid this space of evil-doers. This logic is only possible on the assumption that the borderlands are plagued by crime that originates outside the United States.

The three discursive approaches to the US-Mexican borderlands presented here-contestation, hybridization, and criminalization - all originate in the subjective estimation of the beholder. As Walter D. Mignolo remarks, borders are both real and imagined; they reveal less about the space in which they are located than about the spatialization undertaken by stakeholders:

Inside and outside, center and periphery are double metaphors that are more telling about the loci of enunciation than to the ontology of the world. There are and there aren't inside and outside, center and periphery. What really is is the saying of agents affirming or denying these oppositions within the coloniality of power, the subalternization of knowledge, and the colonial difference. (Local 338)

Old hierarchies and conflicts live on in spatializations and re-spatializations, which reflect the interests of those trying to control a space or to shape the discourse referring to that space.

While the contestation approach in borderlands discourse lays claim to a misappropriated space and while the hybridization approach pleads for or exemplifies interculturalism, the criminalization approach others the borderlands as a territory in crisis that needs to be purged. The three vistas of the US-Mexican 
borderlands in narratives, images, and discourses addressed here reflect the agendas of their proponents: the dispossessed, the open-minded/realists, and the right-wing populists. Social and political practices as well as discourses in literature, media, academia, and political rhetoric have unsettled this space with their competing approaches and agendas. They have made it into the "open wound" of which Gloria Anzaldúa speaks as well as into the vibrant and varied space as which Rolando Hinojosa-Smith characterizes the Lower Rio Grande Valley. That portion of South Texas, which serves as Hinojosa's Yoknapatawpha, can be seen as a pars pro toto for the US-Mexican borderlands in general, for their complex dynamics and diversity: "the Valley, that jurisdictional barrier, is alive and well with love and betrayal, with undying friendships and undying enmities, with racial and class discrimination, with new American citizens and old ones, and with all the tensions that make life worth living" (30).

\section{References}

Acuña, Roldolfo F. Occupied America: A History of Chicanos. 1972. 8th ed., Pearson, 2015.

Anaya, Rudolfo. Bless Me, Ultima. 1972. Warner Books, 1994.

Anzaldúa, Gloria. Borderlands/La Frontera: The New Mestiza. Aunt Lute Books, 1987.

Aranda, José F., Jr. “Contradictory Impulses: María Amparo Ruiz de Burton, Resistance Theory, and the Politics of Chicano/a Studies." American Literature, vol. 70, no. 3, 1998, pp. 551-79.

Bhabha, Homi K. The Location of Culture. Routledge, 1994.

Davis, Julie H. "Trump Orders Mexican Border Wall to Be Built and Plans to Block Syrian Refugees." The New York Times, 25 Jan. 2017, nytimes. com/2017/01/25/us/politics/refugees-immigrants-wall-trump.html/.

"El Plan Espiritual de Aztlán." Aztlán: Essays on the Chicano Homeland, edited by Rudolfo A. Anaya and Franciso Lomelí. 1989. U of New Mexico P, 1991, pp. 1-5.

Faragher, John M. Eternity Street: Violence and Justice in Frontier Los Angeles. W.W. Norton, 2016.

Gómez-Peña, Guillermo. The New World Border: Prophecies, Poems \& Loqueras for the End of the Century. City Lights Books, 1996.

Gonzales, Manuel G. Mexicanos: A History of Mexicans in the United States. Indiana UP, 1999.

Hinojosa, Rolando. The Valley/Estampas del Valle. 1983. Arte Público P, 2014. 
Hinojosa-Smith, Rolando. "Living on the River." Hybrid Americas: Contacts, Contrasts, and Confluences in New World Literatures and Cultures, edited by Josef Raab and Martin Butler. Bilingual P and Lit-Verlag, 2008, pp. 21-31.

Huntington, Samuel P. Who Are We?: The Challenges to America's National Identity. Simon \& Schuster, 2004.

Lee, Michelle Ye Hee. "Donald Trump's False Comments Connecting Mexican Immigrants and Crime." The Washington Post, 8 July 2015, washingtonpost. com/news/fact-checker/wp/2015/07/08/donald-trumps-false-commentsconnecting-mexican-immigrants-and-crime/?utm_term $=.9 \mathrm{a} 7 \mathrm{c} 3 \mathrm{~d} 2 \mathrm{c} 85 \mathrm{df} /$.

Lone Star. Directed and written by John Sayles. Columbia Pictures, Castle Rock Entertainment, 1996. $130 \mathrm{~min}$.

Lusk, Mark, et al., editors. Social Justice in the U.S.-Mexico Border Region. Springer, 2012.

Massey, Doreen. For Space. SAGE Publications, 2005.

Mignolo, Walter D. Local Histories/Global Designs: Coloniality, Subaltern Knowledges, and Border Thinking. Princeton UP, 2000.

Mignolo, Walter D. "Decolonial Reflections on Hemispheric Partitions: From the 'Western Hemisphere' to the 'Eastern Hemisphere." The Routledge Companion to Inter-American Studies, edited by Wilfried Raussert, Routledge, 2017, pp. 59-67.

Paredes, Américo. With His Pistol in His Hand: A Border Ballad and Its Hero. U of Texas P, 1958.

Ruiz de Burton, María Amparo. The Squatter and the Don. 1885. Edited by Rosaura Sánchez and Beatrice Pita, Arte Público P, 1992.

United States, Congress. "Chap. 40: An Act to Ascertain and Settle the Private Land Claims in the State of California." Public Acts of the Thirty-First Congress, pp. 631-34. Digital Commons @ CSUMB, California State University Monterey Bay, digitalcommons.csumb.edu/hornbeck_usa_2_b/3/.

United States, Executive Office of the President [Donald J. Trump]. Executive Order 13767: Border Security and Immigration Enforcement Improvements. 25 Jan. 2017. Federal Register, vol. 82, no. 18, 30 Jan. 2017, pp. 8793-97, www.gpo.gov/fdsys/pkg/FR-2017-01-30/pdf/2017-02095.pdf/.

Wille, Christian, and Markus Hesse. "Spaces: Approaches and Perspectives of Investigation." Spaces and Identities in Border Regions: Politics-MediaSubjects, edited by Christian Wille, et al., transcript, 2016, pp. 25-35. 



\title{
Gabriele Pisarz-Ramirez \\ Florida as a Hemispheric Region
}

\begin{abstract}
The chapter investigates Florida as a "hemispheric region," exploring how its peripheral position at the southeastern tip of the United States, its closeness to the Caribbean, and its tropicality framed it as a space essentially different from the rest of the United States. Florida in the early 19th century was considered an unstable land: regarded as largely uncultivable, on watery ground, and home to unruly populations, its perceived "disorder" and transitional character made it a space of projection for speculations about the nation's expansionist ventures. I focus on two particularities of Florida's topography that highlight its instability and tropicality, the reef and the swamp, and explore their representation in texts by three US American authors: James F. Cooper (Jack Tier), John James Audubon (Ornithological Biographies), and Joshua Giddings (The Exiles of Florida). I argue that all three authors depict Florida as a hemispheric region, and that reefs and swamps become significant symbols in the texts to negotiate issues of nationhood, expansionism, and slavery. The construction of Florida in these texts, however, was guided by the authors' different agendas and the role they attributed to the peninsula in the expanding nation.
\end{abstract}

\section{Introduction}

Talking about the southernmost parts of the United States, literary critic Vera Kutzinski has pointed out that they "in cultural terms [...] are really rimlands of the Caribbean, and have ever been so since slaves were traded between the two areas, well before the Louisiana Purchase in 1803" (61). Discussing William Faulkner's Absalom, Absalom, she observes that in this novel the Caribbean and Latin America "are no longer just a potential political possession, a territory, parts of which have been invaded or annexed by the United States;" rather, the "South' is part of the Caribbean, not vice-versa" (81). This perspective has been reiterated in Immanuel Wallerstein's term "extended Caribbean" (157; 166-67) and, more recently, by David Geggus and David Gaspar who talk about "the greater Caribbean." Both refer to the plantation zone extending between northern Brazil, the Antilles, Florida, and Louisiana-a zone whose production of staple crops was based on slave labor. With respect to the topographical and climatic conditions of this zone, geographer D. W. Meinig has pointed out that the European explorers, on reaching the new continent, had already experienced the southern regions as fundamentally different from northern America: what Meinig calls "tropical America" was perceived by them as "a 
deceptive paradisiacal America of green-mantled islands and perpetual warmth, but fragile in substance and lurking with the dangers of disease and storm" (Meinig 55).

Since the founding of the US Republic, the South in the national imaginary came to function as an internal other and as "a remarkably fertile spatial nexus of the domestic and the foreign" (Greeson 3). In Jennifer Greeson's words, the US South, rather than being a fixed or real place, became a "term of the imagination, a site of national fantasy" (1). As such, it also symbolized the fear that the porous southern periphery of the nation was vulnerable to the intrusion of undesired tropical "contamination." Such contamination could be contagious diseases such as yellow fever that entered the United States not only from the Caribbean, but also undesired people such as "impure" Creoles ${ }^{1}$ from areas where racial purity was not enforced as strictly as in the United States, as well as the "disease" of slave rebellion. ${ }^{2}$ Focusing on the anxieties about the southern border of the nation as well as the connection of the United States with its neighbors, in particular Cuba, Mexico, and Haiti, Gretchen Woertendyke, in a study on the negotiation of these links in popular romances, has suggested to approach the southern peripheries of the United States in terms of what she calls a "hemispheric regionalism"-a perspective that marks the relations between geographies and histories of the United States and the surrounding spaces and that reads the region as "a series of connections between loosely configured areas and spaces adjacent to the southern frontier" (3). Hemispheric regionalism emphasizes the instability and relationality of concepts such as nation or region, framing the southern rimlands as "a shared yet shifting geography" (9).

I aim to show in this chapter how Florida, the peninsula at the southeastern tip of the United States, served as a symbolic space for the negotiation of issues

1 The title of Ashli White's 2003 study 'A Flood of Impure Lava': Saint Dominguan Refugees in the United States, 1791-1820 is based on the perception of refugees from the Haitian Revolution that entered the United States in thousands. These refugees, many of whom were of mixed racial ancestry, were considered with suspicion in the United States (White 3).

2 Slave revolts and tropical diseases such as yellow fever were often compared: for example the Haitian Revolution was presented in public discourse as an epidemic that threatened to spread across the Americas (cf. Hunt 4). In view of this menacing 'disease, southern states such as South Carolina took legal action to prevent colored people from the West Indies to enter the United States, banning the Caribbean slave trade for several years and enacting a large number of repressive measures against resident blacks (Zuckerman 182). 
of nation and empire in the writings of three antebellum US American authors. I am interested in the ways the geographical imagination about Florida translates in these texts, and what these spatializations tell us about the authors' agendas. My exploration is guided by a hemispheric approach as outlined above, and I particularly focus on the representation, in these texts, of two geographical markers-reefs and swamps that reflect Florida's tropicality, its difference from other parts of the nation, and its perceived transitional and unstable character. The texts I refer to are several episodes from John James Audubon's Ornithological Biography (published in four volumes between 1831 and 1839), sections from James Fenimore Cooper's novel Jack Tier or The Florida Reef (1847), and Joshua Giddings' The Exiles of Florida (1858). ${ }^{3}$ Only one of these authors, Audubon, based his representation of Florida on personal experience as he had traveled there in the early 1830s; the other two drew on existing information about the peninsula. Although the region's tropicality and its contested place within the nation become evident in all texts, I argue that the divergent representations of Florida's landscape, of reefs and swamps in these texts, hinged on their authors' perspective on two crucial issues that impacted US national politics of Florida: expansionism and slavery.

In the perception of many Americans in the antebellum period, Florida was not really part of the United States but part of the tropics. Its location at the southernmost border of the nation, its particular geography and climate, as well as its racially diverse population that included maroons, pirates, Indians, and "wreckers"- people considered marginal to and different from the national demographic-epitomized this tropicality in particular ways. Under the Spanish rule, Florida was considered "a backcountry out of control" (Meinig 30): in the words of John Quincy Adams during the negotiations with Spain, the whole province was "a derelict, open to the occupancy of every enemy, civilized or savage, of the United States, and serving no other earthly purpose than as a post of annoyance to them" (qtd. in Meinig 29). The geographical imagination about Florida as "liquid land"4 contradicted the vision of an ever-expanding agrarian pastoral that guided many discourses of expansionism. Amos Doolittle's map of the United States (1784), which was one of the first national maps published and distributed after the American Revolution, and which reached thousands

3 A considerably expanded version of the last part of this chapter about Joshua Giddings is published in a separate article in Amerikastudien/American Studies.

4 A term taken from Ted Levins who, referring to these topographical characteristics, describes Florida as "liquid land"-a region where the distinction between land and water collapsed (Levins). 
of students (Brückner 116n24), showed a Florida-the southern part of which is not well defined; rather, it is fragmented into islands. As Michele Currie has pointed out, this is the way Americans came to imagine Florida in the late 18th century and throughout the early part of the 19th century (Currie 59). Large parts of the peninsula were considered too wet to farm due to its many wetlands and swamps.

Reefs and swamps are landscapes that in contemporary discourse were often described as treacherous and confusing for those not familiar with them, difficult to read and dangerous, while at the same time easily navigable by those acquainted with the area. The Florida Reef was infamous for having caused many shipwrecks, the Florida Straits being a major trading route, and it was considered the realm of smugglers, pirates, and wreckers, while the Florida swamps were seen as an impenetrable labyrinth of morasses. At a time when the United States defined itself as an agrarian republic, swampland was read as "an outward sign of social decay"' (Howarth). As William Howarth has stressed, over thousands of years, the human attitude toward wetland, "in its manifold guises of bog, fen, marsh, or swamp [...] was consistently negative: they were read as dangerous, useless, fearful, filthy, diseased, noxious" (513). The repeated calls to control the reef areas and drain the swamps can be read as a metaphor for establishing order in Florida. Thus Florida's reefs and swamps as unstable spaces in the liquid land epitomized the peninsula's precarious position in the shifting geography of the region.

If American governments early on were eager to take possession of the Floridian peninsula from Spain - their European rival in the New World-it was mainly for two reasons. The first one was the hope to establish full control of the Gulf Coast. The Florida coast was considered an important gateway for the gulf trade: once access to the Gulf had been secured through the Louisiana Purchase, "a whole circuit of coasts-Florida, Cuba, Yucatán, Mexico, Texas-suddenly took on new meaning for Americans, and before long such places were being declared to be of compelling national interest" (Meinig 23). Kirsten Silva Gruesz has pointed out that James Monroe, who claimed that he considered "Cape Florida, \& Cuba, as forming the mouth of the Mississippi," revealed a "modern vision of space" that saw the ports as extensions of the interior of the continent

5 In Letters from an American Farmer, Hector St. John de Crèvecoeur charts the course of civil people: "To examine how the world is gradually settled, how the howling swamp is converted into a pleasing meadow, the rough ridge into a fine field; and to hear the cheerful whistling, the rural song, where there was no sound heard before, save the yell of the savage, the screech of the owl or the hissing of the snake?" (qtd. in Howarth 523). 
(472). The second reason to acquire Florida was to stop the exodus of slaves who fled from the plantations in the Carolinas and Georgia to the peninsula.

The texts by Audubon, Cooper, and Giddings negotiate these public perceptions as well as the national interest in territorial expansion that dominated US politics in the first half of the 19th century. They developed their own spatial constructions of Floridian space-constructions that were guided by their different agendas and the role they attributed to the peninsula in the expanding nation.

\section{John James Audubon: Claiming Florida as the Tropical Garden of the United States}

John James Audubon was a French Creole born as Jean-Jacques Rabin on St. Domingue. He was the illegitimate son of a married French captain, Jean Audubon, who traded in rum, sugar, and slaves, with a Creole chambermaid, Jeanne Rabin. After the Haitian Revolution, Jean Audubon fled to France and to his wife, taking his son and another child he had fathered on the island. The young Rabin was brought up in Nantes and renamed Jean-Jacques FougèreAudubon. He later migrated to America to avoid Napoleon's recruiters, settled in Pennsylvania, and became the most famous ornithologist of his time. His four-volume book, The Birds of America, that contained 435 hand-colored prints depicted the variety of birds in the United States; the accompanying five-volume Ornithological Biography, described these birds in detail and featured a number of "episodes"-short texts in which Audubon described his travel experiences. Audubon traveled to Florida to paint and collect birds in 1831 and 1832, at a time when the peninsula had been in US possession for a mere decade. At that time, colonization was mainly restricted to the coastal areas and to river routes. Sixteen larger plantations in the area between Saint Augustine and New Smyrna were linked to one major thoroughfare, King's Road, by elevated log roads leading through hammocks and swamps (Proby 21). Audubon visited several plantations in the vicinity of Saint Augustine and went on extended excursions into unexplored territory along the Halifax river and Saint Johns river before traveling to the Florida Keys on a US Revenue Cutter. The texts discussed here are "episodes" dealing with his Florida trip and published in part II and III of Audubon's Ornithological Biography. They are interspersed in between the description and images of the birds, and they detail his impressions during his voyage.

Margaret Curzon Welch has observed that the episodes were "Audubon's most obvious concession to popular taste" in a publication that reconciled the 
demands of entertainment and science (54). Audubon depended on subscribers to finance his books and his trips, and he cultivated his public image as an "American woodsman" and interpreter of nature to Americans. Performing during his public appearances in "frontier garb, cradling in his arms a rifle" (Nobles, John James Audubon 97) as shown in an 1826 portrait painting by John Syme, he was a sort of superstar of his time (Gruse). He thus represented a distinctly American - and masculine-approach to natural history, stylizing himself as a "pioneer naturalist" (Nobles, "John James Audubon"). One motivation for patrons to subscribe to Audubon's works was, apart from a general interest in natural history, "the desire to promote worthy causes" (Welch 54). This connection between "patrons and patriotism" ${ }^{\prime 6}$ may account for the divergent depiction of the landscape in some of the "episodes" and in letters that Audubon wrote to his friends and his wife. In general, in the episodes, we find a far more enthusiastic description that tends to leave out much of the drabness of the area and the difficulties in traversing it. $^{7}$

From the episodes emerges the image of a Florida that is tropical, featuring all the risks of tropical landscapes (e.g. alligators, storms, reefs, and swamps), and decidedly different from other American regions, but that is, after all, part of the United States and as such knowable and controllable. Against the view that Florida's swamps and reefs were part of a chaotic and impenetrable wilderness, Audubon strove to make swamp and reef areas comprehensible to Americans, emphasizing their beauty and usefulness in his writings. Natural history appears as a part of manifest destiny (a term not yet in use at the time when he traveled but a guiding idea): to study the landscape and the fauna of the different parts of the nation was a way of appropriating them for Americans.

In both parts of the trip, Audubon is staying at the home of plantation owners who offered him room and board as well as local guides for his excursions. One of the first episodes deals with Audubon's visit to the plantation of Colonel Rees at the end of a lengthy trip from his base at Bulow plantation. This trip included passages through swampy and sandy, barren areas as well as several encounters with large alligators. On approaching the Rees plantation, Audubon compares his party with a colonial expedition into the interior of Africa:

6 This is the title of a 1966 dissertation by Lillian B. Miller on Patrons and Patriotism: The Encouragement of the Fine Arts in the United States, 1790-1860.

7 For a discussion of the letters and reports that Audubon wrote to friends and to his wife, see Proby; Nobles, John James Audubon. 
But at length we perceived the tracks of living beings, and soon after saw the huts of Colonel Rees' negroes. Scarcely could ever an African traveler have approached the city of Timbuctoo with more excited curiosity than we felt in approaching this plantation. (Audubon, "Spring Garden" 265)

Comparing Florida to an as-yet-little-explored territory in Africa, and the plantation to Timbuctoo-an oasis at the edge of the Sahara desert-Audubon fashions himself as an expeditioner on a colonial mission, suggesting that he is traveling in an area that, in its remoteness from the ordinary surroundings of most Americans, resembles distant tropical Africa. Significantly, the presence of slaves and slave huts figures to Audubon as a sign of entering a well-ordered space with known hierarchies, while the area surrounding it consists of unpredictable, unknown territory full of "muddy pools" ("Spring Garden" 263), "thicket[s] of scrubby oak," "desolate country," and "pine barrens" that "seemed to us as if we were approaching the end of the world" (263). Reassuringly, on the plantation, "refreshments were immediately placed before" the travelers (263) by the slaves, allowing Audubon to spend "the evening in agreeable conversation" (263). The plantation presented a familiar order-the Audubons, who had lived in Kentucky (1810 to 1819), a slaveholding state, like many others, kept a number of slaves, whom Audubon calls servants in his writings (Rhodes 268). Of the swamp surrounding the plantation, he remarks that the soil is "of good quality [...] rich and very productive" (265), clearly with an eye for the possibilities of cultivation. And even if he experiences the scenery of swamps and ranks grass surrounding the plantation as "dismal," he praises its potential recreational value to his readers. His host invites him on a tour to a "celebrated spring," that he describes in detail, proclaiming that it "afforded me pleasure sufficient to counter-balance the tediousness of my journey" (265). A day later, his host takes him to

a small island covered with wild orange trees, the luxuriance and freshness of which were not less pleasing to the sight, than the perfume of their flowers was to the smell. The group seemed to me like a rich bouquet formed by nature to afford consolation to the weary traveler. ("Spring Garden" 267)

The swamp here appears not only as the realm of wild beasts, treacherous "mud holes," and tropical plants, but also as a potential tourist site for the American citizen.

As Katherine Proby (25) has shown, in his letter to G.W. Featherstonhaugh, a publisher and geologist, the description of the island sounds markedly different: here, it is dominated by his uneasiness:

The general wildness of the eternal labyrinths of waters and marshes, interlocked, and apparently never ending; the whole surrounded by interminable swamps -all these things had a tendency to depress my spirits, notwithstanding some beautiful flowers, rich looking fruits, a pure sky, and ample sheets of water at my feet. (qtd. in Proby 25) 
Contrary to his "public" representation of Florida as a pastoral space, in more private correspondence, he points to the discrepancy between his expectations and his experience. In the same letter to Featherstonhaugh, he remarks:

Here I am in the Floridas, thought I, a country that received its name from the odours wafted from the orange groves, to the boats of the first discoverers, and which from my childhood I have consecrated in my imagination as the garden of the United States. A garden where all that is not mud, mud, mud, is sand, sand, sand; where the fruit is so sour that it is not eatable [...] Mr. Bartram was the first one to call this a garden, but he is to be forgiven; he was an enthusiastic botanist... (qtd. in Proby 26)

None of these doubts can be found in the episodes, where the Floridian space is shown as one in the process of becoming well ordered and controlled. In this order, everything and everybody has its place: on encountering a Seminole Indian on the Saint Johns river, who is approaching them in his canoe offering fish, Audubon comments:

The poor, dejected son of the woods, endowed with talents of the highest order, although rarely acknowledged by the proud usurpers of his native soil, has spent the night in fishing, and the morning in procuring the superb-feathered game of the swampy thickets; and with both he comes to offer them for our acceptance. ("St. John's River" 293)

Thus, both the black slaves on the Rees plantation and the Seminole in the swamps in Audubon's text figure as reassuring signs of a recognizable racial and social order. This perspective appears guided by wishful thinking in view of the outbreak of the Second Seminole War just a few years later-a war that was one of the most lengthy and costly military conflicts of the US government with a native tribe-that prevented Audubon from returning to Florida and continuing his exploration of birds and that led to the destruction, by Seminoles and maroons, of some of the plantations where he stayed in 1831. The image of the submissive "vanishing Native" was quite popular in the writing of this period, but at least for the Florida swamps, it was a precipitate notion, as my discussion of Giddings' text shows.

A number of episodes are dedicated to Audubon's trip to the Florida Keys-an area infamous for its dangerous reef that became the wrecking ground for many ships passing through the Florida Straits. In "The Wreckers of Florida," Audubon recalls the stories he had heard about the wreckers, men who earned their living by saving the cargo of vessels that had been shipwrecked:

Often had I been informed of the cruel and cowardly methods which it was alleged they employ to allure vessels of all nations to the dreaded reefs, that they might plunder their cargoes, and rob their crews and passengers of their effects. I therefore could have little desire to meet with such men under any circumstances... with the name of wreckers, 
there were in my mind associated ideas of piratical depredation, barbarous usage, and even murder. ("Wreckers" 158)

Significantly, Audubon on the Florida Keys was a guest of Jacob Housman, a wrecker king, a fact that remains undisclosed in the episodes (Proby 39). Audubon sailed to the Keys on a Revenue Cutter-a government ship dispatched to enforce customs and to fight piracy in the Caribbean and along the Gulf coast. His description of the reef and the wreckers in "The Florida Keys" and "The Wreckers of Florida" markedly contradicts conventional renderings, as neither reef nor wreckers in his description have anything threatening. On arriving at Indian Key, he observes that the ship had to pass over the reef, a fact barely mentioned in a half sentence, before Audubon begins to praise the landscape:

Our vessel once over the coral reef that everywhere stretches along the shore like a great wall reared by an army of giants, we found ourselves in safe anchoring grounds, within a few furlongs of the land. The next moment saw the oars of a boat propelling us towards the shore, and in brief time we stood on the desired beach. ("Keys" 312)

The "dreaded reef" in this scene does not present any dangers, the landscape is pleasant, and with clockwork punctuality, the visitors are collected by a boat to be able to enjoy the beauty of the island. The rest of the passage reads like a promotional brochure advertising tropical birds and plants and healthy air almost as if to invite visitors:

With what delightful feelings did we gaze on the objects around us! - the gorgeous flowers, the singular and beautiful plants, the luxuriant trees. The balmy air which we breathed filled us with animation, so pure and salubrious did it seem to be. The birds which we saw were almost all new to us; their lovely forms appeared to be arrayed in more brilliant apparel than I had ever seen before... ("Keys" 312)

This Edenic landscape that suggests the earthly realization of a prelapsarian state of grace reminds of the texts by early explorers and colonizers about the New World - texts that described the Americas, especially the West Indies, as a space free of the economic hardships and the political corruption of Europe (Cocks 20). Like the explorers, Audubon narrates the tropics as a desirable and inviting space, just as he does in his earlier episode about the swamps. Once again, on the next day, Audubon praises a glorious morning where the reef is just a pleasant part of the landscape. While enjoying the scenery and the sunrise, the party sailing on the government ship seems to be in full dominion of the territory. As Audubon meditates on the landscape, he feels urged to recall the powers of the creator:

The next morning was delightful. The gentle sea-breeze glided over the flowery isle, the horizon was clear, and all was silent, save the long breakers that rushed over the distant reefs. As we were proceeding towards some Keys seldom visited by men, the sun rose from 
the bosom of the waters with a burst of glory that flashed on my soul the idea of that power which called into existence so magnificent an object. ("Keys" 316)

The idea of manifest destiny becomes evident in this representation of the government ship traveling between the Keys now in US possession as Audubon presents a vision of the Keys to his readers that contradicts accounts by other authors of the reef area as treacherous, disturbing, and risky. Spatializing the reef area as a tourist paradise, he rewrites its islands into a tropical garden for Americans to dwell in and to enjoy its birds and plants.

This impression of a domesticated reef area becomes even stronger in the second episode, "The Wreckers of Florida," which describes an encounter with the infamous wreckers of the Keys. Upon seeing a wrecking ship, Audubon recounts his distrust of the wreckers, drawing on reports about their reputation as dishonorable. Surprisingly though, on first sight of the wrecking ship, he points out the perfect state of the ship and the orderliness of its crew; he exclaims: "What a beautiful vessel! we all thought; how trim, how clean rigged, and how well manned!" "Wreckers" 158). Upon entering the ship onto which he has been invited by the wreckers, he observes that "Silence and order prevailed on her decks" (159) and then goes on to describe the wreckers as "stout, active men, cleanly and smart in their attire" (159). He gets invited to dinner on the ship and socializes with the wreckers, buys shells from them, and remarks that the captains of wreckers' ships are "jovial, good-natured sons of Neptune who manifested a disposition to be polite and hospitable, and to afford every facility to persons passing up and down the Reef” ("Wreckers" 159).

Several times in the episode, he points out that the wreckers identify as men from "down east" suggesting that they originated from the New England coast, as if trying to remove any possible link to Caribbean piracy. Thus, it is not only the wrecking ships that are beyond reproach but also the wreckers who have a clearly definable origin as white East Coast Americans, contrary to their reputation as dangerous aliens of unclear racial and ethnic descent. This "whitening" of the wreckers is significant in view of the fact that Audubon himself throughout his life in the United States tried to obscure his own Caribbean descent: the man who was born as Jean-Jacques Rabin on St. Domingue renamed himself "John James Audubon" and claimed to have been born on a Louisiana plantation. ${ }^{8}$ Gregory Nobles (John James Audubon 201-02) has highlighted several passages

8 According to Gregory Nobles, Audubon's racial background is uncertain: his mother Jeanne Rabin was Creole, which could mean that she was of mixed heritage. Several African American registers have claimed Audubon as a mixed-race person with some degree of African descent (Nobles John James Audubon 16-17). 
in Audubon's writings in which he stresses his white origin and the inferiority of nonwhites.

Audubon in this episode takes a lot of effort to appropriate not only the landscape but also the wreckers of Florida as part of the nation-presenting the Keys as nonthreatening, making them American for Americans, to "tame the tropics" so to say. The disorder associated with Florida, Audubon seems to suggest, is only a rumor. As he concludes: "How different, thought I, is often the knowledge of things acquired by personal observation from that obtained by report!" (160). Roughly, ten years after the acquisition of Florida by the United States, Audubon's agenda was cultural annexation of the Floridian wilderness. Rather than exploiting the region's unstable and relational position in the hemisphere to point out its difference, he aims at embracing Florida's geography, fauna, and even its wreckers, locating them firmly within the United States. Safely established in the discursive contexts of expansionism, white superiority, and a belief in progress, Audubon sought to dismiss all doubts about tropical Florida's as well as about his own affiliation to the nation. Florida (as well as himself) may have connections to the Caribbean tropics, but in his writings, the author and the landscape he described were certainly identified as American. While the unpredictability and violence conventionally associated with the reef area and its wreckers are submerged, Audubon enacts the violence of the frontier as "American Woodsman," killing thousands of birds to be able to make drawings of them, categorize, and describe them for his Ornithological Biography. Dramatizing his hunting activities in the episodes and boasting about the number of birds he has killed, ${ }^{9}$ he performs his American identity as a frontiersman, enacting what Richard Slotkin, in Regeneration through Violence, has described as "the myth of the hunter"- a myth "of self-renewal or self-creation through acts of violence" (556), that displays the hunter's mastery over nature. As the birds of Florida are appropriated for American audiences, the expansionist acquisition of the peninsula comes full circle.

9 For example, in the episode "The Florida Keys" he describes hunting cormorants: "And there we were, with four hundred cormorants' nests over our heads. The birds were sitting, and when we fired, the number that dropped as if dead was such that I thought by some unaccountable means or other we had killed the whole colony [...]" (312). Later their guide instructs them: "If you wish it, you may load The Lady of the Green Mantle [their ship] with them in less than a week. Stand still, my lads; and now, gentlemen, in ten minutes you and I will bring down a score of them.' And so we did" ("The Florida Keys" 314). 


\section{James Fenimore Cooper: The Florida Reef as a Site of Treason}

Published 16 years after Audubon's Ornithological Biography, in 1848, James Fenimore Cooper's novel Jack Tier: The Florida Reef makes the reef the site of a conflict between smugglers and authorities in the period of the US-Mexican War. The novel was first published serially in Graham's Magazine under the title Rose Budd before appearing in book form. The Mexican American War that started in 1846 and ended with the annexation of large parts of Mexico's north in 1848 has been described as "America's forgotten war" (Johannsen 96) - but at the time when it broke out it was discussed most controversially by the American public. As the first war wholly fought on foreign soil, it was seen by many as an imperial venture that contradicted republican ideals. It also deepened the sectional conflict over slavery, as the newly gained territory raised anxieties about the balance of slave states and free states. Northern abolitionists such as William Lloyd Garrison and Charles Sumner opposed the war, as did many writers, such as John Greenleaf Whittier, William Cullen Bryant, Henry David Thoreau, and Ralph Waldo Emerson.

From a hemispheric perspective, as Kirsten Silva Gruesz points out, the war was just the continuation of the expansionist move into formerly Spanish territories that had begun with the purchase of West Florida. Gruesz bemoans the repression, "in most discussions, of the relationship between Caribbean-Atlantic expansion on the one hand and westward-Pacific on the other - and the way the relationship is mediated, both materially and imaginatively, by the Gulf of Mexico" (475). President Monroe's vision of Florida and Cuba as "forming the mouth of the Mississippi" (qtd. in Gruesz 472) was part of a vision that saw the expansionism of US territory into the Caribbean, but also later into Texas and Mexico, related to the expansion of the United States' slave empire into these areas.

Cooper's novel brings both directions of expansionism together in having its main conflict unfold in the Gulf waters surrounding the Florida Reef. The novel's plot focuses on an American captain (Captain Stephen Spike) who sails from New York City to Key West on his ship Molly Swash, allegedly to transport flour but who is actually planning to smuggle gunpowder to the Mexican government. Spike embodies the ruthless wealth-searcher who has abandoned all ideals of patriotism or republicanism, signaling the emergence of the market economy in the United States. He aims to sell the powder and his ship to Don Juan Montefalderon, a Mexican patriot whom he has arranged to meet at the Dry Tortugas - a remote part of the Florida Keys approximately 70 miles west of Key West. To prevent his discovery, Spike has hidden the kegs of gunpowder 
in large flour barrels-a strategy that proves successful when his ship has to undergo inspection on leaving the New York City port. To avoid contact with the American sloop-of-war Poughkeepsee that is patrolling the reef area, he sails around the island of Cuba and repeatedly hides in the mazes of the reef's shoals, islands, and lagoons that are difficult to access for the large government ship.

The Florida Reef is thus depicted as a space of crime, a site where the nation is in danger of being betrayed to an enemy nation. Other than in Audubon's text from the 1830s where the government revenue cutter seems to be in full control of the reef area, in Jack Tier the smuggler knows to navigate the reef much better than the captain of the Poughkeepsie, managing to escape renewed inspection. Cooper's description of the reef portrays the Key area as a precarious space that renders the nation vulnerable to dangerous forces from abroad and that serves as loophole for smugglers like Spike:

The Florida Reef, with all its dangers, windings, and rocks, was as well known to [Spike] as the entrances to the port of New York. In addition to its larger channels, of which there are three or four, through which ships of size can pass, it had many others that would admit only vessels of a lighter draught of water. The brig was not flying light, it is true, but she was merely in good ballast trim, and passages would be available to her, into which the Poughkeepsie would not dare to venture. (Cooper 303)

Captain Spike can be sure that even if the government ship would come close, "escape was easy enough to one who knew the passages of the reef and islets" (Cooper 190). In Cooper's text, the reef is a liminal space in many ways: it is situated between land and sea; it is also located in a geographical liminal zone between the United States, Cuba, and Mexico. The conflict between Mexico and the United States is here imagined as a conflict in a space that is not Mexico but also somehow not really the United States because they do not fully dominate it.

This liminal state is highlighted by the novel's plot that stresses the dangers of traveling through the reef area and that includes encounters with sharks, tornados, and wreckers. As the ship anchors at the Dry Tortugas and Captain Spike is in the process of transferring his barrels of gunpowder to the Mexican schooner, both ships are hit by a tropical storm "of appalling strength and frightful inconsistency" (Cooper 149) that sinks the Mexican schooner with all hands on board in a matter of minutes. Tornadoes and hurricanes that are frequent in the waters around Florida represent a tropical force that cannot be contained or predicted. Unlike in Audubon's "domesticated" portrayal of the reef area, Cooper's protagonists see themselves exposed to an uncontrollable sea. Sharks have a prominent place in many scenes of the novel. The passengers of the Molly Swash, after having been abandoned by Captain Spike, seek refuge on 
the upturned hull of Don Montefalderon's schooner, where they are faced with the danger of being ripped apart by the animals:

"What things are those glancing about the vessel?" cried Rose, almost in the same breath; "those dark, sharp-looking sticks—see, there are five or six of them! and they move as if fastened to something under the water that pulls them about."

"Them's the customers I mean, Miss Rose," answered Jack, in the same strain as that in which he had first spoken; "they're the same thing at sea as lawyers be ashore, and seem made to live on other folks. Them's sharks." [...] The light had, by this time, so far returned as to enable the party [...] to see the fins of half a dozen sharks, which were already prowling about the wreck, the almost necessary consequence of their proximity to a reef in that latitude. (Cooper 247)

Comparing the sharks to American lawyers prying for profits, Cooper comments not only on the reef, but also on the state of American society. Just as the sharks may rip apart the American passengers on the schooner, the American nation faces the risk of being destroyed by greed and search for profit, as symbolized by lawyers. This greed is also symbolized by Captain Spike himself, who is compared in the novel to a wrecker and thus implicitly to a shark: Spike negotiates with Montefalderon to rescue the latter's ship for half of the gold doubloons it contains, doing exactly what he has accused the wreckers of doing earlier: he talks about the "devils of wreckers [who] hang about these reefs. Let this brig only get fast on a rock, and they would turn up, like sharks, all around us, each with his maw open for salvage" (Cooper 413). Later in the story, the mate of the Molly Swash, Harry Mulford, who sets out to save some of the passengers, dives into the water to retrieve a boat, only to find the sharks about to attack him: "Every fin was gliding toward him-a dark array of swift and furious foes. Ten thousand bayonets, levelled in their line, could not have been one-half as terrible" (Cooper 284).

The sharks at the reef in a wider sense can also be read as a comment on the risks of leading an expansionist war against Mexico, a war driven by the desire to expand the production of profitable staple crops based on slave labor. Cooper's decision to make the Florida Reef a setting to dramatize a story about the Mexican War is significant in view of his own ambivalence about the war-an ambivalence that becomes visible in the novel's preface. Here Cooper observes:

When this book was commenced, it was generally supposed that the Mexican war would end, after a few months of hostilities. Such was never the opinion of the writer. He has ever looked forward to a protracted struggle; and, now that Congress has begun to interfere, sees as little probability of its termination, as on the day it commenced. (Cooper v)

Cooper was critical of the expansion into western (and southern) territories. In the conflict between those forces endorsing the consolidation of the nation versus 
those arguing for further expansion, Cooper opted for consolidation. To a friend he wrote, "[w]e have conquered already more territory than we want" (Iglesias 263).

It is quite fitting then, that in Jack Tier, the reef area becomes a site of death: it turns into a wet grave for the majority of the crew and passengers of both the American and the Mexican ship. Not only does Don Montefalderon's schooner sink, pulling his entire crew into the depths of the ocean, but in a subsequent chapter Captain Spike, in an attempt to escape the government ship, throws his crew and passengers overboard to lighten the weight of his brig and save himself. As they die among the sharks, the captain is fatally wounded himself by shots from the government ship; his ship founders on a bank of coral and becomes the bounty of wreckers: "The wreckers went out the moment the news of the calamity of the Swash reached their ears. Some went in quest of the doubloons of the schooner, and others to pick up anything valuable that might be discovered in the neighbourhood of the stranded brig" (Cooper 496-97).

Eventually, at the novel's end, the buried body of Captain Spike is washed away at Key West by "the hurricane of 1846, which is known to have occurred only a few months later" and his bones are left "among the wrecks and relics of the Florida Reef" (Cooper 506).

In Cooper's novel, the reef is produced as a transnational zone different from the rest of the nation-a space that provides access to other parts of the Americas, yet in need of heightened supervision. That this space will eventually be controlled seems as certain to Cooper with the fact that the Florida Keys are of strategic importance for the nation, as Cooper has one of his protagonists observe: "It [the Dry Tortugas] may turn out to be the key to the Gulf of Mexico, one of these days, maam. Uncle Sam is surveying the reef, and intends to do something here, I believe. When Uncle Sam is really in earnest, he is capable of performing great things" (Cooper 220).

While Cooper presented the Florida Reef as the site of a story of greed, death, and betrayal, he at the same time seems to have regarded the expansion into the Gulf region as inevitable. Implicitly endorsing the vision that the United States would eventually gain control of the entire hemisphere, he has his narrator ponder future developments:

Of late years, the government of the United States has turned its attention to the capabilities of the Florida Reef, as an advanced naval station ... the day is not probably very distant when fleets will lie at anchor among the islets described in our earlier chapters, or garnish the fine waters of Key West. (Cooper 481)

Nevertheless, in the same passage, the narrator makes clear that the plans for the development of Key West are rather "a promise" (481) than a reliable prospect. 
A few weeks after the end of the tale, he relates, Key West was hit by a hurricane and was "washed away" (510). Thus the attempt to dominate the reef areajust as expansionism beyond the nation's borders-is shown to remain a risky enterprise.

\section{Joshua Giddings: Florida as a Space of Maroon Resistance}

While the Florida Reef in Cooper's text emerges as a liminal as well as perilous space, the peninsula's swamps function as a marker of the area's dangerous tropicality in Joshua Giddings' history of fugitive slaves. Writer Barbara Hurd calls swamps "places of transition [...] of overlap, of blurred lines, and of ambiguity" (7), pointing to the elusiveness of this landscape. Swamps in Giddings' account become a site where the power of the slave-owner ends, inverting the hierarchies between masters and slaves. Giddings' text gives evidence of the specific significance the swamp assumes in the geographical imagination of slaveowners and abolitionists.

Like other coastal areas in the Greater Caribbean in the 18th and 19th centuries, Florida became a major destination for runaway slaves. It shared this condition with other places in the hemisphere, such as parts of the Central American coastal lands or the interior of French Guyana and Suriname (Putnam 5). As ethnographer Richard Price has observed, "[c]ommunities formed by self-liberated slaves dotted the fringes of plantation America, from Brazil to the southeastern United States, from Peru to the American Southwest for more than four centuries" (Price 1). In colonial times, Spanish authorities granted these runaways liberty in return for their military support against British interests and allowed them to live in their own communities, own arms and property, and select their own leaders (Mulroy 3). When Florida became a US territory, slave-owners who had lost their slaves enhanced their efforts to retrieve their "property," appealing to the US government for help. The solution to the problem of Florida that the federal government had pursued earlier and that was driven forward as soon as Andrew Jackson had moved into office was to remove the native population from Florida and to return the fugitive slaves to their owners. With the Indian Removal Act of 1830, the determination to drive the resident tribes out of the Southeast to areas west of the Mississippi river became a government policy. However, in the case of Florida, this endeavor was considerably postponed by the Seminoles' alliance with escaped slaves or maroons (Black Seminoles). Together, Seminoles and Black Seminoles resisted the armed forces throughout multiple military conflicts which became known as the Seminole Wars. Seminoles and wreckers also often helped fugitive slaves 
to continue their journey to the Bahamas, where they were safe from persecution by slave-hunters.

The history of the Black Seminoles and the specific role of Florida as a tropical space of radical resistance at the periphery of the United States were brought to national attention in 1858 by Joshua Giddings' book The Exiles of Florida: The Crimes Committed by Our Government against the Maroons Who Fled from South Carolina and Other Slave States. Joshua Reed Giddings (1795-1864) was an attorney and a US Congressman from the Western Reserve of Ohio who served in the House of Representatives for over 20 years (from 1838 to 1858). A prominent opponent of slavery throughout his entire political career, Giddings was an active supporter of the Underground Railroad, and his Ashtabula County home reportedly was a stop on the Railroad (Stewart, Joshua R. Giddings 8). As a member of Congress, Giddings could not openly call for rebellion, ${ }^{10}$ but he nevertheless emphatically defended the rights of freedom-seeking slaves to use violence in defending themselves against their oppressors (Stewart, "Joshua Giddings" 115).

Giddings' widely read history of the Black Seminoles was a provocative text in various ways. By calling the fugitive slaves "maroons," he called up the history of militant fugitive slave communities in the Caribbean, communities that were linked with "notions of guerrilla activity" (Diouf 4$),{ }^{11}$ implicitly contextualizing maroon resistance in a larger hemispheric tradition of radical revolt. Giddings also revealed the entanglement of slavery and national expansion, challenging the slaveholding South's increasing control of national politics and enlightening his contemporaries about the American government's involvement in slavery, delivering strong arguments to the abolitionist cause. ${ }^{12} \mathrm{As}$ he demonstrates, the

10 In 1841, Giddings violated the House's "gag rule" that limited congressional discussion of slavery with an open condemnation of the Jackson administration which he accused of financing the capture of escaped slaves in Florida with tax money: "[T]his Administration, now just out of power, has dealt in human flesh; the funds of Government, drawn from the pockets of free laborers, have been paid for the capture of fugitive slaves" in Florida ("Speech of Mr. Giddings of Ohio in the House of Representatives." The Congressional Globe, vol. 9, Feb. 1841, p. 349.).

11 As Sylvaine Diouf (3) has pointed out, southerners denied that maroons existed in Florida or elsewhere in the United States.

12 As the text's title that points to the "crimes committed by our government" shows (and as several historians have pointed out), Giddings was primarily interested in the plight of runaway slaves (and less in the situation of the Seminoles) as he considered the Second Seminole War an important issue through which abolitionists could garner support for the antislavery case (Joy 201; Kerber 279). 
federal government was involved in assisting the slaveholding southerners: it used tax money to refund slave-owners for the loss of their escaped slaves who had fled to Florida (64); it later financed the war against the exiles and Seminoles with tax money; it paid the Creek Indians for hunting escaped slaves and returning them to their owners (161).

In the first part of his history of the Black Seminoles, Giddings presents Florida as a haven for escaped slaves under Spanish rule, making clear that the direction of fugitive mobility did not have to be necessarily from South to North and emphasizing the hemispheric dimension of this mobility. In the geographical imagination presented by his text, Spanish Florida was a kind of Canaan for the exiles: they formed communities and cultivated the land, raised cattle and, as Giddings puts it, were over several generations, "[s]hut out from the cares and strifes of more civilized men" and "happy in their own social solitude" (34). Giddings makes a direct connection between their peacefulness and their liberty under Spanish rule, suggesting that the later violence of the Seminole Wars was a direct effect of the attempt to re-enslave them.

When Florida became American and white settlers moved into its territories, the situation for the exiles changed dramatically as they were no longer under the protection of the Spanish crown. Giddings highlights the development of the conflict that led to the First and Second Seminole Wars: as slave-owners kept capturing slaves and returning them to slavery, maroon communities were attacked by troops and the Seminole Indians were gradually displaced from their territories by white settlers in Florida; hostilities merged into armed resistance from the maroons and Seminoles who allied against their common enemy, the white forces. The beginning of the Second Seminole War in 1835 marked what some historians regard as the biggest slave revolt in the United States-a revolt that, as Giddings points out, was born from "the hatred which slavery alone can engender in the human breast" (118). ${ }^{13}$ Plantations were raided, property destroyed, and families killed. ${ }^{14}$

13 The isolated position of Florida as a space that was unlike most other places in the nation may have contributed to historians' perception of the revolt as an incident unrelated to other slave rebellions in the United States. One could argue that just like Florida was relegated to the periphery of the nation, the maroons have been relegated to the margins of national history-their successful revolt has never been properly acknowledged.

14 An 1836 account of the horrors that East Florida planters experienced in the revolt reports that "a great number of the most valuable plantations have been totally destroyed, and whole families missing; and as the Indians have been frequently 
Giddings presents Florida as a space that, due to its topographical conditions, offers the exiles many opportunities to resist their opponents and to avoid re-enslavement as the maroons-many of which had originally resided in the northern part of the peninsula-moved to the swamps and forests in Central and Southern Florida. As he observes, "the Exiles were taking up their residence farther in the interior of the territory, upon the Whitlacoochee, the St. John's, the Big Cypress Swamp, the islands in the Great Wahoo Swamp, and places far retired from civilization" (Giddings 70). The isolated plantations were vulnerable to attacks from exiles and Seminoles; moreover, the number of Indians and exiles (Black Seminoles) increased constantly as slaves left the burnt plantations and joined the Seminole forces (Wasserman 247), ${ }^{15}$ thus prolonging the conflict between Indians and whites in Florida.

In this military conflict, the swamp areas of Central and Southern Florida became a space that stood as a symbol for maroon radical resistance against re-enslavement. By reference to the map of Florida, Giddings remarks:

[I]t will be perceived that the great swamps, extensive everglades, hommocks, ponds and lakes, which spread over that Territory, must present great difficulties in the progress of troops embodied in military force; while a small party, following the footsteps of their leader, would pass over, around or through them with facility. The Great Okefenoka Swamp, lying on the south line of Georgia and the northern portion of Florida, afforded a retreat for small parties of Indians and Exiles, from which they sallied forth and committed depredations upon the people of southern Georgia, murdering families, burning buildings and devastating plantations. The swamps bordering on the Withlacoochee, the Great Wahoo Swamp, and other fastnesses on the western portion of the Peninsula, gave shelter to other bands, who, in like manner, wreaked their vengeance upon the inhabitants of that portion of the Territory. (282-83)

Giddings' text suggests that the successes of the rebels can be attributed to their familiarity with and effective use of the swamp areas. From the swamps, the exiles strike back-burning plantations, killing whites, and spreading devastation. For slave-owners and troops, swamp areas turned out to be an unpredictable space in which the army was helpless against their well-organized enemies. The complexity of the territory turned out to be an advantage for the exiles while turning into a deceptive and finally deathly space for the army. Giddings describes one

discovered dancing to and fro around their burning dwellings, there can be but little doubt but some of the missing were consumed in them" (qtd. in Wasserman 245).

15 Barcia observes that "toward the end of the conflict, in 1838, the rebels' ranks had grown to approximately 1,600 , as more than 500 liberated slaves from the toppled sugar empire joined the cause" (10). 
confrontation between the army and their Seminole and black opponents that became known as the "Dade Massacre": the army under the command of Major Dade was "encamped in scientific order," while their "encampment had been selected according to military science" (104). The troops were "unsuspicious of the hidden death which beset their pathway" (104), lacking imagination of what expected them in the swamps. On a morning that was "peaceful and quiet as the breath of summer" (104), they proceeded in full view of their opponents who were hidden behind trees. When they opened fire, the troops were immediately "thrown into disorder," and finally every man was killed, while the exiles had minimal losses. In this and other passages, Giddings stresses the swamps' dangerous tropicality as a marker of the landscape's elusiveness and the resilience of its inhabitants. The logic of the swamp dwellers is presented as superior to the "scientific" order of the military forces, resulting in their destruction.

Although Giddings does not directly allude to the Caribbean slave revolts that had produced anxieties in plantation owners throughout the slaveholding Americas, the parallels to the successful slave rebellion in Haiti that had used similar guerilla tactics are obvious. In some cases, as Giddings explains, the Seminoles were aided by "maroons from Cuba" (275) who had fled from Spanish masters, as in one incident in South Florida that he interprets as an act of vengeance by the Seminoles and their allies which found "their brethren driven from their own possessions" (276), and finally took up arms against the United States. A group of these maroons and Indians crossed over to an island on the Florida Keys and "attacked the dwellings, burned the storehouses, and destroyed most of the property belonging to the inhabitants" (276), while some of the inhabitants were murdered. The same group also participated in the wrecking business, plundering wrecked ships, and killing their crews.

Giddings repeatedly takes pains to point out who is responsible for these outbreaks of violence, explaining the revolt as the outcome of the crimes the government has committed against Seminoles and exiled slaves in Florida:

All that the Exiles or Indians had ever asked or desired of the American government, was to leave them to themselves; to permit them to remain as they were, as they had been for many generations. The war on our part had not been commenced for the attainment of any high or noble purpose [...] Our national influence and military power had been put forth to reenslave our fellow men; to transform immortal beings into chattels, and make them the property of slaveholders; to oppose the rights of human nature; and the legitimate fruits of this policy were gathered in a plentiful harvest of crime, bloodshed and individual suffering. (Giddings 119) 
Just as many of the more radical abolitionists in the 1850s, Giddings reveals the neat spatial separation of a slaveholding south and a north that was free of the sin of slavery to be empty rhetoric, exposing the involvement of the US government in protecting slave-owners and their property. As Giddings makes clear, the government even legally took possession of about 90 escaped slaves who were caught by army troops in Florida during the Second Seminole War (161), so that, as he points out, "the people of the nation became the actual owners of these ninety slaves, so far as the Executive could bind them to the ownership of human flesh" (Giddings 161). The idea that the north is a "pure" space not involved in the business of slavery is clearly shown to be an illusion $(4,102)$.

The Second Seminole War turned into a prolonged, costly, and unwinnable war. It ended by US government decision, without treaty or capitulation. While the maroons after long negotiations were allowed to leave Florida together with the Seminoles, and were promised freedom by the government, Giddings make clear that this promise was treacherous. The maroons and Seminoles did not receive any land for themselves in the "western territory" but were expected to move onto the territory of the Creek Indians, a slaveholding tribe whose members had worked as paid slave-hunters for whites. A longer passage of the narrative is dedicated to the role of John Horse, a Black Seminole leader who led more than one hundred Black Seminoles from Indian Territory across the US border to Mexico where they created a settlement in Nacimiento, Coahuila, a space where they were finally safe from slavery. Giddings stresses the fundamental difference between what expected the exiles on US territory and and beyond the nation's borders: while they ran the risk of being re-enslaved within the United States, no matter where they settled, "Mexico was free! No slave clanked his chains under its government" (332). He thus suggests that the only safe place for slaves is a space not within the nation but outside of it.

At the end of his text Giddings links his narrative of fugitive resistance to more recent events in US expansionist history, specifically to the conflicts resulting from the addition of slave states to the US after the US-Mexican War. Drawing parallels between the fugitives who had fled from Georgia to Spanish Florida and slaves who escaped from Texas plantations to Mexico, he suggests that attempts to retrieve these slaves would result in similarly violent conflicts as had characterized the situation at the Florida frontier. His text ends with the warning that "many of the scenes [of violence] which were enacted in Florida, will most likely be again presented on our southwestern frontier [...] and the same effects will be likely to follow" (338). Giddings, like Cooper, thus brings together CaribbeanAtlantic and westward-Pacific expansionism by dwelling on the violence engendered by both. 
Giddings' text presents Florida as part of the Caribbean rimlands: a space that was home to "unruly" populations and that was close to the Caribbean where slave rebellions such as the Haitian Revolution had overturned white dominance. In his history, Giddings constructs Florida as an uncontainable space of radical resistance that functions as a threat to the proslavery United States. In the imagination of the US government and of slave-owners in the South, Florida remained a 'disordered' frontier space in need of control-a space where backward and riotous people dwelled and that needed to be cleaned up. At the time when Giddings published his denouncement of government policies concerning Florida maroons in 1858, this process of "cleaning up Florida" was almost completed, as expansionist policies had driven out the majority of native and black people from the peninsula. At the same time, the empire of slavery did not stop growing, as filibusters supported by southern slave-owners had invaded Nicaragua and threatened to install slavery there, and the US-Mexican War had added new slave states to the union.

\section{Conclusion}

The different spatializations of Florida in Audubon's, Cooper's, and Giddings' texts derive from their divergent perspectives on the nation's future and their views on expansionist politics and slavery. Audubon's episodes endorse an expansionist outlook, in which he fashions himself as an "American Woodsman" who helps to claim Florida and its nature as part of an American pastoral. During his trip of the yet largely unsettled tropical wilderness of swamp areas along the Halifax and Saint Johns rivers and on the Key islands, he describes plantations as well as the wreckers' ship as well-ordered islands of a civilization that will soon dominate the entire peninsula. Reading the episodes in the context of a hemispheric regionalism and the geographical imagination of Americans concerning the position of Florida as part of the "Caribbean rimlands," it becomes evident that Audubon in his depiction of the landscape tries to contain and domesticate the tropics, aiming at incorporating the peninsula into the nation. Quite different from this spatial imagination, Cooper's novel frames the reef area in images of a dangerous tropicality and emphasizes the porousness of the southern periphery. The Florida Keys in his text are depicted as gateway or "key" to the Gulf of Mexico-a perspective that reflects the expansionist politics of his era. However, at the same time, they also dramatize the risks of expansionism: in Cooper's text, the reef is the site where enemy forces can enter the nation, and where unpredictable tropical nature brings death and destruction. Giddings likewise evokes an uncontainable tropicality and spatializes Florida as the site of 
rebellion, evoking maroon resistance against slavery in other plantation societies in the Caribbean basin. At the same time, he-like Cooper-connects expansion into Florida and the Gulf area to the annexation of Mexican territories in the Southwest. All authors depict Florida as a "hemispheric region" that links the United States to its neighbors, yet the conclusions they draw from this are quite different.

\section{References}

Audubon, John J. “Spring Garden”; “St. John's River in Florida”. Ornithological Biography: Or an Account of the Habits of the Birds of the United States of America, Vol. 2, Adam and Charles Black, 1832-39, pp. 263-67; 291-95.

Audubon, John J. “The Florida Keys." Ornithological Biography: Or an Account of the Habits of the Birds of the United States of America, Vol. 2, Adam and Charles Black, 1832-39, pp. 312-16.

Audubon, John J. “The Wreckers of Florida." Ornithological Biography: Or an Account of the Habits of the Birds of the United States of America, Vol. 3, Adam and Charles Black, 1832-39, pp. 158-63.

Barcia, Daniel. Restless Liberty: The Fall of Florida's Maroon Haven and the Largest Slave Rebellion in U.S. History, 1835-1838. 2015. Harvard University, BA Thesis.

Brückner, Martin. The Geographic Revolution in Early America: Maps, Literacy, and National Identity. University of North Carolina Press, 2006.

Cocks, Catherine. Tropical Whites: The Rise of the Tourist South in the Americas. University of Pennsylvania Press, 2013.

Cooper, James F. Jack Tier or The Florida Reef. 1848. Appleton and Company, 1877.

Currie, Michele A. E. Founding Florida: Language and Geography at the Edge of America. 2009. UCAL Irvine, PhD Dissertation.

Diouf, Sylvaine. Slavery's Exiles: The Story of the American Maroons. New York University Press, 2014.

Geggus, David P, and David Barry Gaspar. A Turbulent Time: The French Revolution and the Greater Caribbean. Indiana University Press, 1997.

Giddings, Joshua. The Exiles of Florida: The Crimes Committed by Our Government against the Maroons Who Fled from South Carolina and Other Slave States. Columbia, Follet, Foster and Company, 1858. Internet Archive, https://archive.org/details/exilesoffloridao00giddrich/page/n7.

Greeson, Jennifer R. Our South: Geographic Fantasy and the Rise of National Literature. Harvard University Press, 2010. 
Gruesz, Kirsten S. “The Gulf of Mexico System and the 'Latinness' of New Orleans." American Literary History, vol. 18, no. 3, 2006, pp. 468-95.

Gruse, Doug. "Museum Files: Audubon Granddaughter Rewrites Family

Records." The Poststar, 23 Feb. 2014, poststar.com/news/local/museum-filesaudubon-granddaughter-rewrites-family-records/article_bfac58a0-9cdc11e3-97ab-001a4bcf887a.html/.

Howarth, William. "Imagined Territory: The Writing of Wetlands." New Literary History, vol. 30, no. 3, 1999, pp. 509-39.

Hunt, Alfred. Haitis Influence on Antebellum America: Slumbering Volcano in the Caribbean. Louisiana State University Press, 1988.

Hurd, Barbara. Stirring the Mud: On Swamps, Bogs, and the Human Imagination. Beacon Press, 2001.

Iglesias, Luis A. The Emergence of a Global Nation: James Fenimore Cooper's Invention of the American Sea Novel. 2006. Rutgers, State University of New Jersey, PhD Dissertation.

Johannsen, Robert W. “America's Forgotten War." The Wilson Quarterly, vol. 20, no. 2, 1996, pp. 96-107.

Joy, Natalie I. Hydra's Head: Fighting Slavery and Indian Removal in Antebellum America. 2008. UCAL Los Angeles, PhD Dissertation.

Kerber, Linda. "The Abolitionist Perception of the Indian." Journal of American History, vol. 62, no. 2, 1975, pp. 271-95.

Kutzinski, Vera M. "Borders and Bodies: The United States, America, and the Caribbean." CR: The New Centennial Review, vol. 1, no. 2, 2001, pp. 55-88.

Levins, Ted. Liquid Land: A Journey through the Florida Everglades. University of Georgia Press, 2003.

Meinig, D. W. The Shaping of America: A Geographical Perspective on 500 Years of History. Vol. 2: Continental America, 1800-1867. Yale University Press, 1993.

Miller, Lillian B. Patrons and Patriotism: The Encouragement of the Fine Arts in the United States, 1790-1860. 1966. University of Chicago, PhD Dissertation.

Mulroy, Kevin. Freedom on the Border: The Seminole Maroons in Florida, the Indian Territory, Coahuila, and Texas. Texas Tech University Press, 1993.

Nobles, Gregory. "John James Audubon, the American 'Hunter-Naturalist." Common-Place, vol. 12, no. 2, 2012, www.common-place-archives.org/ vol-12/no-02/nobles/.

Nobles, Gregory. John James Audubon: The Nature of the American Woodsman. University of Pennsylvania Press, 2017. 
Price, Richard. "Maroons in the Caribbean." Caribbean Atlas, edited by Romain Cruse \& Kevon Rhiney, 2013, www.caribbean-atlas.com/en/themes/wavesof-colonization-and-control-in-the-caribbean/waves-of-colonization/ maroons-in-the-caribbean.html/.

Proby, Katherine. "John James Audubon." Audubon in Florida: With Selections from the Writings of John James Audubon, Ed. Katherine Proby. University of Miami Press, 1974, pp. 5-50.

Putnam, Lara. "Borderlands and Border Crossers: Migrants and Boundaries in the Greater Caribbean, 1840-1940." Small Axe 43, vol. 18, no. 1, 2014, pp. 7-21.

Rhodes, Richard. John James Audubon: The Making of an American. Knopf Doubleday, 2004.

Slotkin, Richard. Regeneration through Violence: The Mythology of the American Frontier, 1600-1860. Wesleyan University Press, 1996.

Stewart, James B. Joshua R. Giddings and the Tactics of Radical Politics. Press of Case Western Reserve University, 1970.

Stewart, James B. "Joshua Giddings, Antislavery Violence, and the politics of Congressional Honor." Abolitionist Politics and the Coming of the Civil War, edited by James Brewer Stewart, University of Massachusetts Press, 2008, pp. 113-38.

Wallerstein, Immanuel. The Modern World System II: Mercantilism and the Consolidation of the European World-Economy, 1600-1750. Academic Press, 1980.

Wasserman, Adam E. A People's History of Florida 1513-1876: How Africans, Seminoles, Women, and Lower Class Whites Shaped the Sunshine State, 2010.

Welch, Margaret C. John James Audubon and His American Audience: Art, Science, and Nature, 1830-1860. 1988. University of Pennsylvania, PhD Dissertation.

White, Ashli. "A Flood of Impure Lava": Saint Dominguan Refugees in the United States, 1791-1820. 2003. Columbia University, PhD Dissertation.

Woertendyke, Gretchen J. Hemispheric Regionalism: Romance and the Geography of Genre. Oxford University Press, 2016.

Zuckerman, Michael. Almost Chosen People: Oblique Biographies in the American Grain. University of California Press, 1993. 



\title{
Megan Maruschke
}

\section{Bordering through the Lens of Slavery and Abolition in the United States}

\begin{abstract}
Political geographers refer to historical research on Europe's borderlands as informing the emergence of "the border," a spatial strategy associated with the rise of territoriality and the nation-state since the mid-19th century. Research on North American borderlands in the 18th and 19th century, however, has not been taken up as readily by political geographers. This chapter discusses the implications of this gap and, referencing research on the "geopolitics of freedom," considers the emergence side-by-side of spaces of slavery and spaces of emancipation in North America to be one avenue for understanding the development of bordering practices in the United States. Observing internal border production in the United States, a union made up of individual states, may be instructive for understanding the border's functionality beyond delimiting state sovereignty. By looking at the boundaries of slavery, this chapter argues that bordering can be understood not only as a container of state sovereignty but also as a tool in processes of state territorialization.
\end{abstract}

\section{Introduction}

On July 4, 1776, the Second Continental Congress declared thirteen of the twentysix British colonies in the Americas independent from the British Empire, which, following a war that consumed the major powers of the day-the French, Spanish, British empires, and many Native American nations-culminated in the creation of the United States of America, a confederated patchwork of states. The boundaries of the new American republic were defined in Versailles on September 3, 1783. According to Marie-Jeanne Rossignol, external border practices emerged as a strategy to begin to control United States (US) state space depicted in this treaty (see 3-24).

This chapter arises out of tensions in the historiography on US independence when read from a spatial turn perspective. Historians shift their spatial terminology when discussing an independent United States: the term "boundary" to describe the edge of an imperial claim quite abruptly becomes a "border" following independence. These authors are not concerned with understanding the emergence of the United States through a spatial lens but rather the birth of an independent nation. ${ }^{1}$ However, my own research concerns itself with processes

1 "Nation" is a term used by contemporaries. It was an evolving concept at the time. The US "founding fathers" used the term "nation" as well as "republic" and sometimes "empire" to describe the United States. 
of respatialization in the Americas at the time of the Atlantic revolutionary cycle (1770s-1830s) (for Atlantic Revolutions, see Palmer and Godechot; for recent approaches, see Albertone and de Francesco; Geggus; Klooster); this research is a synthesis and therefore relies on secondary literature. The question is whether to read the shift in terminology from "boundary" to "border" as a term used by contemporaries to refer to a new spatial format guiding the organization of societies post-independence. Rather, I suspect that this shift has to do with historians retroactively applying current ideas of how states are spatially organized-the border being a key component of contemporary state territoriality-onto the past when studying what is thought of as the emergence of today's state system in the late 18th and early 19th century.

Spatial terminology in historiography is developed in conversation with categorizations and typologies derived from the social sciences. Likewise, geographers and political scientists have looked to history to inform their understanding of the emergence of contemporary states' forms of spatial organization. For example, in opening a paper on borders, political geographer John Agnew cites historian Peter Sahlins' well-known study, Boundaries: The Making of France and Spain in the Pyrenees. In this work, Sahlins recounts centuries of activity along what had appeared to most historians to be a stable border between today's Spain and France. Instead, Sahlins shows the active construction of boundary practices through to the Napoleonic period, including the "nationalization" of the boundary during the course of the French Revolution (c. 1789-1800). Sahlins begins his book by noting the importance of studying the emergence of this border: nation-states are characterized by territoriality-states' "exclusive jurisdiction over a delimited territory; and the boundaries of territorial competence define the sovereignty of a state" (Sahlins 2-3). In geography and history disciplines, the nation-state, epitomized by post-revolutionary France, appears to be a specific spatial format, one that must be markedly different from standard understandings of empires out of which independent states in the Americas emerged. Borders are, therefore, an essential component of territoriality as they define the limits of state sovereignty. This state spatiality contrasts with ideal type empires defined by hierarchies, composite places, and buffer zones along which imperial control fades.

Another body of scholarship where tensions emerge between the western European and the North American contexts is the study of "borderlands." Rarely are European borderlands brought together conceptually with those in America (an exception is Rossignol 5-6). The research on American borderlands, which I will discuss subsequently, seems divorced from the research on European borderlands that in historical narratives, in reference to political geography, are 
understood as the precursors to today's borders. In contrast, in the case of North America, the boundaries between empires and the US "nation-state" would eventually be subsumed by a single state stretching from one coast to the other. Rather than harden over the course of the 19th century, the US western "border" at independence is constantly extended. Furthermore, external border creation between the United States and British Canada unfolded along a parallel, a practice not widely used in western Europe. Authorities faced difficulty in identifying US citizens from Canadian British subjects (Hatter). How do we, therefore, begin to understand American bordering and border-transcending experiences in light of research on Europe's emerging "national" borders in the same period, which political geographers understand to be historical research on the border? That is, what do history and geography miss by not examining North American experiences with borders in the production of ideal types?

This chapter examines bordering in the early US republic through the lens of slavery and abolition. The goal is to question some narratives in history and political geography about the emergence of borders with nationalism that have focused largely on European experiences, keeping in mind Benedict Anderson's reminder that independent "nations" emerged first in the Americas before being taken up as a model for organizing societies in Europe and thereafter in subsequent periods of decolonization (47-65). As such, border-making processes in Europe are entangled in the American experience, which remains underemphasized in geography and history disciplines. The geopolitics of US slavery has not been integrated into the literature on borders and/or borderlands in the broader American or European context. This chapter argues that understanding how slavery became a bounded institution in the Americas-examined here through the lens of the United States-should also inform the historicization of the border as a component of the contemporary nation-state. Doing so underpins the different social tensions in North America, in contrast to Europe, that led to the employment of what we now consider a similar form of spatial organization, the border, on both sides of the Atlantic during the 19th century. Incorporating the US context into the study of borders in political geography can emphasize how the emergence of borders in the 19th century are not only national but part of ongoing imperial practices that enforced social hierarchies, racial exclusion, and forced labor both between states and within them.

\section{Borderlands and the Geopolitics of Freedom}

The Americas have been considered key in informing a shift in spatial thinking among European sovereigns, such that we cannot speak of an exclusively 
comparative framework for understanding the emergence of borders; rather, the development of new understandings of organizing societies in Europe were intertwined with the American experience. Until the early 19th century, the open and uncharted spaces of the Americas (even through the early 19th century, the American Northwest remained underexplored by Europeans) were key in this shift. In western Europe, kingdoms were bound together through personal loyalties, that is, through the control of subjects; such a system produced a patchwork geography made up of places and parishes that could not be clearly bounded. In North American claims, the dearth of subjects who could be tied to particular places led Europeans to focus on land holdings. Maps became the most legitimate form of visualizing space in the Americas, such that treaties from the early 18th century onwards nearly always involved the production of maps with delineated boundary lines to indicate areas of control (Miquelon). In contrast to islands (Gillis), continents allowed for frontiers, buffer zones, and borderlands to emerge, which simultaneously served as spaces to shield imperial powers from one another, as spaces between empires that allowed for trade and exchange, and as opportunities for expansion and conquest (for a comparative look at frontiers, see Mikesel; for borderlands versus frontiers, see Adelman and Aron).

This practice of demarcating boundaries on maps, based on developments in cartography, shifted European sovereigns' perspectives on how to organize their claims in both Europe and the Americas (Branch). Jordan Branch argues that map making gained importance first in the Americas before itself becoming the key way to visualize kingdoms in Europe. As European leaders became accustomed to visualizing their polities on maps, delineated by clear boundaries, this practice became the norm. Therefore, imperial practices in the Americas developed over time, informing a shift towards imagining imperial space, in Europe and America, in increasingly territorial terms. Territoriality is therefore not only found in the nation-state; rather, historians argue that territoriality emerged as a strategy to manage national and imperial space during the 19th century (Maier; for an overview of research on territory and borders, see Rutz). Imperial experiences in the Americas were central to that development, yet this remains underemphasized in global history narratives that position the European nation-state that emerges in the 19th century as a model that is later implemented by post-colonial societies.

The literature on borderlands in western Europe shows that the production of borders was connected to delineating polities based on language and culture. France, for example, was depicted as a territorial unit with clear borders to the east and south from the end of the 16th century. But only by the late 17th and 18 th century did this view shift towards removing internal fortifications and 
militarizing France's "borders" (Branch 142-64). Despite imagining a clear line that defined France's internal and external space, its borders with Spain and what became Germany were still not solved into the 19th and even the 20th century. In the late 19th century, both Germany and France sent surveyors to try to map the language boundary between German and French speakers, without finding much of a solution, as is well known (recently, Dunlop).

Laura di Fiore shows that this method of border production is representative of the western European experience. In one of the few works that conceptually brings together the usually detailed studies of individual borders, she demonstrates that historians of various European border regions note the complex entanglement of the production of borders from above with the actions of social actors from below. These processes resulted in producing borderlands rather than a border that contained national territory. Based on how processes of visualizing state space emerged in the Americas, we may assume that border production took on a different form where independent states emerged prior to those in Europe and nations defined by language and culture did not exist (Anderson 47-65). Surely, without concepts of culture, nation, and language guiding state boundaries, different processes were at play than those in Europe over the course of the 19th century.

The bordering of slavery that this chapter discusses does not refer to its existing boundaries. Slavery could be found in some northern states right up to the civil war, and Andrés Reséndez shows that "the other slavery" of Native Americans in the American West acquired from Mexico maintained slavery even through the early 20th century as it was less obvious and culturally more pervasive than chattel slavery (see also Kiser). Furthermore, maroon settlements, though more often associated with French Caribbean and Spanish American slavery, endured in the bayous of the US South, allowing de facto freedom (Schoolman 161). Nevertheless, the contrasting narratives and actions of slaves, free blacks, abolitionists, and slave-owners sought to control the geographical scope of slavery in the new republic, which affected patterns of internal migration and settlement of planters/slave-owners, fugitives, and free blacks. This illustrates the perspective that territorialization emerges in the 19th century as a strategy to regain control over certain "flows" (Middell). Furthermore, narrating boundaries put abolitionist and pro-slavery policies into action in certain places. These spatial practices - which emerged through law, policy, flight, kidnapping, petitions, etc.- - served to extend or limit slavery's reach.

Literature on the geopolitics of freedom may refer to the "borderlands" of slavery. This term in an American context takes on a different function than the European usage discussed above. Jeremy Adelman and Stephen Aron 
stress the difference between the American frontier, a space where geographical and cultural distinctions were not clearly delineated, and borderlands, the "contested boundaries between colonial domains" (816). Such a definition already differentiates the term and the practice from the European context, a point the authors themselves acknowledge. These borderlands and frontiers persisted in wake of the creation of an independent state in North America but declined around the world over the course of the 19th century as trade rivalries rather than territorial claims drove national and imperial competition (816). For contemporaries, experiences on the edge of empire could both be characterized by fluidity (and therefore liberty) and violence (Jacoby). Kathleen DuVal's Independence Lost is a thoughtful illustration of North American life beyond imperial powers' full reach. Some of this flexibility is captured in DuVal's portrayal of native communities (see also Richter), and Jane Landers tells the story of life in free black towns in Spanish imperial backcountry. Much of this borderlands research focuses on the cultural aspects of these "in-between" spaces. It looks at the day to day lives of its inhabitants-often Native Americans and free blacks, but also white creoles. Borderlands, in this context, takes on a wider range of imaginations than what we seen in the use of the term in Europe.

Within this American perspective on borderlands is an even sharper contrast: the borderlands of race, slavery, and freedom. Prior to the wave of independence that swept across the Americas, slavery was practiced in each American empire. There was some degree of fluidity between slavery and freedom. Runaways who escaped to other empires could be granted freedom, as this practice contributed to instability in rival empires. Borderlands, then, were important spaces in lending slaves an outlet to freedom. Other possibilities to gain freedom included self-purchase and religious conversion (for a variety of systems, see Tannenbaum). Children born to slaves and a white parent (usually the father, the slave master) would also be free in colonies such as Haiti, which by the time of the Haitian and French revolutions hosted a sizable population of free blacks, many of whom were slaveholders themselves. Maroon communities developed throughout the Americas, including in the US West and South, namely Florida, and in the mountain communities between French SaintDomingue and Spanish Santo Domingo. The connections maintained between maroons and slaves blurred the distinctions between slavery and freedom (Fick 61). These practices began to shift following the opening of spaces of emancipation with Pennsylvania's Emancipation Act of March 1, 1780.

In line with DuVal's notion of "independence lost," scholars who focus on slavery in North America see American independence as a shift in slavery and the "geopolitics of freedom" (Wong; see also Troutman). The remainder of this 
chapter traces some of these works, which have emerged in the American context, to understand the creation of a specific geography of freedom. They often focus on the practices near the boundary between freedom and slavery: the MasonDixon line, a demarcation separating Pennsylvania, Maryland, Delaware, and West Virginia (Virginia until 1863). The purpose of these studies is to show how the actions of African Americans themselves gave this line meaning; how they imagined and practiced spaces of emancipation; and through these practices were agents in their own freedom (Newman "Transformation" 60-106). In the following, the chapter unravels how certain practices and narratives gave the boundary a meaning that we can begin to interpret as bordering.

\section{Narrating the Borders of Freedom and Slavery}

Like other decolonized states in the Americas, the United States struggled with how to manage slavery, a practice seemingly incompatible with the ideals of the modern republic. The United States emerged out of the revolutionary cycle that swept across the Atlantic world from the 1770s through the 1830s, which was connected to transatlantic discussions regarding the slave trade, slavery, and abolition. In the United States, by the early 1800s, about 20 percent of the population were slaves; only in South Carolina was there a black majority. In contrast, the Caribbean was constituted by eight or nine black slaves per white planter (Rossignol 122). In the United States, the institution of slavery was maintained in a piecemeal system; in Haiti (1804), whites remaining on the island were massacred and slavery was abolished; from the 1820s, slaves were emancipated in a piecemeal system throughout newly independent Spanish America, though native slavery proved resilient in Mexico and the southwestern US (Reséndez). Pennsylvania became the first state in the western hemisphere to enact the "freesoil" principle (Peabody), "the belief among enslaved people and their allies that certain geographies and territorial domains abetted black freedom claims," through the Emancipation Act of March 1, 1780 (Newman "Lucky to be Born" 414). The southern border of Pennsylvania, the Mason-Dixon line, gave meaning to the boundaries of freedom and slavery following American independence.

2 The free-soil principle derives from British and French law, whereby slaves, once in the metropole, could gain their freedom. In practice, loopholes allowed slave owners from the colonies traveling with slaves to maintain their slaves even upon arrival in the metropole. Following independence, Haiti, too, enacted the free-soil principle and expanded its scope to include Haitian citizenship (see Ferrer). 
This line, however, emerged much earlier and had not previously been associated with the boundaries of slavery and freedom. Pennsylvania and its southern neighbor, Delaware, had a long history of territorial disputes-a story to do with inaccurate maps. As settlements further west increased, so did unrest as additional parties like Maryland and Virginia (today's West Virginia) disputed claims, as well. War broke out in the 1730s, known as Cresap's War; part of Pennsylvania had been invaded and occupied by other colonies. When he learned of the war, the king had a temporary boundary drawn between the colonies and later sent Charles Mason and Jeremiah Dixon to survey this line between 1763 and 1767 as part of the resolution among the various parties. Their role was to establish a "permanent line" to divide the colonies (Mason qtd. in Spero 2). During this same period, another line was established: the proclamation line.

The proclamation line was planned following the treaty negotiations of the Seven Years' War (Edelson). This line sought to set a boundary at the Appalachians, which would mark the furthest point of settlement for British North America, establishing a "middle ground" for Native American communities between the Spanish and the British (White). Native Americans would therefore provide a buffer between European imperial powers in North America. British officials had indicated a boundary for Pennsylvania, as well as other colonies. Some fortifications in the frontier zone-perceived by colonists as a militarized zone often in-between powers or on the fringes of settlements-were removed following the war's conclusion. The new spatial framework that followed enforced boundaries rather than frontier zones, thus reducing the use of "internal" fortifications. However, settlers continued to perceive their location as a frontier. They demanded imperial fortifications and additional support, which were not granted. Seizing on instability, which itself emerged from the widening gap between how the British board of trade ordered American colonial space and the experiences of colonists, Virginia and Connecticut seized sections of Pennsylvania (for a detailed history, see Spero).The Mason-Dixon line was extended in 1779 as a resolution to these border incursions.

Following independence, as the United States sought to solidify its external borders with the British Empire to the north and the Spanish Empire to the west (see Rossignol 3-24), an internal boundary began to emerge. Several states such as Pennsylvania in 1780 and New Jersey in 1804 began the process of abolishing slavery through acts of emancipation. "Territories" 3 that had since joined the

3 "Territories" in this sense does not refer to the concept territoriality. Rather, it was a status for US claims driven by settlers. Once "territories" reached a certain number of inhabitants, they could be granted statehood and receive proportional representation in congress. 
union as states such as Ohio, Illinois, and Indiana followed suit. These states shared a commonality: they were located north of Pennsylvania's state border. The Mason-Dixon line took on a new meaning as a symbol of the threshold to freedom. In his work on slavery and the Mason-Dixon line, Stanley Harrold describes the clashes between the "lower north" and the "border south." These states pursued interstate diplomacy to deal with the fact that different legal structures made both slave ownership and abolition precarious in this region. As Harrold describes, conflict began along the Mason-Dixon line, which charged it with new meaning after 1780. The banks of the Ohio River faced conflict by the early 1800s as did the banks of the Mississippi River by the 1820s (Harrold 10). In 1808, congress banned the slave trade, increasing the economic value of slaves. As emancipation progressed in the north, many slaves from the southern border region were sold further south; slaves and free blacks in the border region fled northwards; and kidnappers prowled the lower north to capture free blacks to sell in the south. Harrold describes how a border region emerged out of these differing legal and economic systems that produced instability and violence.

But slaves, free blacks, and abolitionists, too, charged the line and Pennsylvania's landscape with meaning. Along with the violence and devastation, the MasonDixon line became a symbol of the "free-soil" principle in Pennsylvania through their actions (Newman "Lucky to be Born"). Disregarding the technicalities of Pennsylvania's Emancipation Act, which did not abolish slavery outright but liberated slaves gradually and did not apply to fugitives, free and enslaved blacks gave Pennsylvania and its borders a moral meaning. As Richard Newman ("Lucky to be Born") argues, Pennsylvania was hardly the Eden slaves were looking for, but they also willfully misinterpreted the narrow protections offered through the Emancipation Act to expand the scope and scale of the act. Through their actions, they sought to extend and enhance the law's protections. Slaves, even in the deep south, filed petitions and lawsuits for their freedom by claiming ties to the state. Escaped slaves made use of the free-soil principle to argue for their residency in Pennsylvania. Emancipated slaves in Pennsylvania as well as other states fought hard to maintain and expand legal protections from slavery and the scope of emancipation and abolition laws.

According to Manisha Sinha, freedom petitions were part of a critical engagement of blacks, free and enslaved, with revolutionary ideology; their engagement sought to challenge the omnipresent and persistent threat of slavery to all blacks in America and, moreover, to secure black citizenship in the American republic (as opposed to colonization). Once free, former slaves sought to expand the scope of emancipation and to ensure through the court system that a free status once gained could not be revoked. Establishing the free-soil principle in Pennsylvania 
was key among these efforts to widen the freedoms promised by an independent America. The most striking example is Massachusetts, where two slaves sued for their freedom, which led the supreme judicial court of Massachusetts to abolish slavery in 1783. African Americans themselves were a central driving force behind the initiation and expansion of emancipation acts (Sinha). Their actions from independence onwards defined the acts' scope and the boundaries of slavery.

The range of practices that began to define what some authors have called borderlands-referring to the violence and insecurity on both sides of the border-and what other authors have termed a border region or border/ boundary-indicating the diverging legal structures that contrasted one "territory" from another "territory,"-sit uneasily with the aforementioned European literature on borderlands and the eventual production of borders as a strategy to deal with state space and define the limits of state sovereignty. To begin with, the borders of slavery were not produced exclusively at the state's limits, although that surely becomes relevant if we extend the scope of this chapter to Canada or Haiti. Examining the boundaries of slavery and abolition in the 19th-century United States contributes to an understanding of the concept border by highlighting its use in internal demarcations of state space.

Therefore, observing internal border production in the United States, a union made up of individual states, may be instructive for understanding the border's functionality beyond delimiting state sovereignty. Southern states sent diplomatic envoys to northern states to seek to pass legislation to return fugitives; when that strategy failed, the federal government finally stepped in with the fugitive slave act of 1850, which only increased tensions along the border region. Individual northern states had considered initiating war on individual southern states for their incursions and threats to state sovereignty. Therefore, in the history of border production and the rise of the nation-state, historians and geographers can also look at how subnational states and regions may have articulated their own sovereignty and legal regimes through the production of borders. This story appears to diverge from the European context where culture and language helped to define state borders. However, it does point to a common understanding that a variety of actors-such as abolitionist societies and slaves themselves-were involved in producing the border through their spatial imaginations and narrations of freedom.

\section{Mapping the Expansion of Slavery}

The first part of this chapter discusses how intrinsic mapping and cartography were to rethinking concepts of political space and the eventual production of 
boundary lines as tools in demarcating areas of state control. These practices became especially important for depicting space in North America. Likewise, an expanding United States was triumphantly visualized cartographically from the days of the early republic; meanwhile, this expansion produced tensions regarding what adding new states to the union would mean for the institution of slavery. Though slaves were included in the US census, they were not represented cartographically until 1861, which we can read as a disinterest in including slaves in the national story of an expanding nation that unfolded in atlases and other popular visual representations.

Mapping first became relevant in America for colonists leading up to and following independence. Prior to the revolution, most news articles were either local or related to events taken from London's newspapers. They referenced the metropole. But leading up to the revolution, newspapers began to depict events that occurred elsewhere in the colonies and provided maps of locations so that colonists could visualize where these events occurred (Parkinson, ch. 1). Following revolution, maps showed the development, and notably the spread, of the new nation and became increasingly important for making the state legible to statesmen (on making the state legible, see Scott). In pedagogy, too, maps allowed pupils to imagine their national affiliation and better retain information. One example is Emma Willard's understanding of US history as a history that was both spatially and chronologically unfolding through the expansion of US territory (Schulten).

Along with mapping, census statistics became an increasingly salient way for the state to track its growth and measure local populations (Cohen). Fundamentally, statistics on population were used to measure proportional representation at the state and federal level of government following the compromise at the constitutional convention, which sought to balance the representation of states with fewer residents along with those with many residents through Article 1, Section 2 of the constitution. On top of this was the question of whether slaves, who were considered property after all, should be accounted for in states' representation in congress. The agreed to $3 / 5$ rule, whereby a slave was calculated as $3 / 5$ a resident, opened the door to the statistical calculation of slaves in America. Slaves, therefore, were included from the first official census in 1790 onwards (Cohen 45, 48). As Susan Schulten notes in her monograph on history and cartography in 19th century America, these statistics on slave population density were used from the 1830s onwards by abolitionists and pro-slavery advocates to prove their respective cases. These statistics could be combined with other information to show that, for example, crime was higher in areas with more free blacks or, on the other hand, that northern states that had abolished slavery 
saw higher rates of education. Despite these attempts to manipulate statistics to objectively argue for or against slavery, slavery nationwide was not mapped until just before the Civil War (1861-1865). The US Coast Survey, a federal scientific agency, used data from the census of 1860 to render the distribution and density of slavery in the US South cartographically, the first such map to do so. The map was published in September 1861 and was used by President Abraham Lincoln to understand the extent of slavery and to coordinate the war effort, which would be a force towards emancipation (Schulten, ch. 4). This map illustrated where slavery was densest, and therefore, where slaveholders in the south would most dearly feel the emancipation of slaves.

Though slavery had not been depicted cartographically by the federal government until the 1860s, the geography of the new nation was very much based on questions of slavery. The emergence of new states into the union and new western territories had produced tensions over the issue of slavery. Topographical features such as rivers like the Mississippi and the Ohio had become for a short while natural boundaries for this "unnatural" institution when in 1804 congress needed to decide whether the Mississippi would indeed be a boundary for slavery or accommodate the wishes of the white settlers the United States acquired along with the Louisiana purchase (1803), a question that by 1805 was resolved by allowing certain regulations on slavery and the slave trade to lapse (Hammond). Internal boundary making of US slavery therefore upheld several centuries of European geographic tradition, whereby natural features such as mountain ranges and rivers served as boundaries. This coincided with the "manmade" lines like the Mason-Dixon line that were given meaning by the actions of slaves, abolitionists, and the reactions of slaveholders. In this case, boundaries served as signifiers in the struggle over slavery and emancipation.

But more than a signifier, as I argued in the previous section, bordering became an active territorialization strategy that allowed abolitionists and their sympathizers in congress to try to control the persistence and the spread of slavery. The literature on territorialization generally sees the border as an external demarcation of sovereignty while territorialization is characterized as the project/process by which society forms a more cohesive whole (the creation of institutions, implementing nationwide education, and the use of communications and transport technologies such as canals, railways, and roads) (Maier; Middell 163-66; for canals and territoriality, see Mukerji). However, internal bordering also became a practice of balancing state space. Abolitionists could use bordering as a negotiation tool to construct slavery as an institution that was not limitless but could be controlled. On the other side of the coin, slaveholders also sought to extend the practice beyond the south. As in the case of upper and lower French Louisiana 
residents, they played on old loyalties to other imperial powers to stoke fear into congress to allow slavery to continue unhindered; these residents required allowing slavery in exchange for joining the union willingly rather than requiring force. Resident groups threatened reunification with France-though it is hard to say if such reunification would have been probable let alone possible. As Francois Furstenberg shows, connecting the trans-Appalachian region to the American republic was a delicate project and meant that the divisions in the early republic ran east and west rather than north and south.

In the context of slavery, northern and southern politicians were divided on the terms and conditions of the acceptance of new territories as states. Americans created a pathway to statehood for newly acquired territories. This is a deviation from previous imperial hierarchies of loyalties and dependencies (DuVal 344); US "imperialism" did, however, rely extensively on expansion. While the thirteen original colonies played out negotiations over emancipation and abolition at the state level, the newly acquired territories required federal level negotiations on the make-up of each new territory and its future as a state, bringing the question of slavery to a national scale in each case. Slavery was only one problem as the diverse racial configurations of western territories, including Louisiana, threatened the white, national order (Frymer). In response, congress began to encourage migration from the original colonies to the newly acquired territories to increase national sentiment and ensure that the public understood the benefits the US state system could offer. But the question remained open whether slaveowners should be encouraged to settle there (Hammond). The ambiguity about the future of slavery in the region was a deciding factor for some slave-owners who were not willing to risk slave manumission.

Narrating the historical development of the new nation was closely tied to watching it expand. While mapping slavery was not a priority until just before the Civil War, the persistence of slavery evoked questions about the conditions for the expansion of the US territory to include additional states in the union, a process that was mapped with vigor. Bordering and accepting new subnational states, therefore, became a political act imposed from politicians at the federal level to try to control the spread of slavery. Internal bordering through the lens of slavery and abolition in the United States was integral to state territorialization, that is, a project of balancing national state space with slave states and free states. This internal bordering appears not only to diverge from external border production in Europe but also from internal demarcations arising out of, most notably, French departmentalization, which involved new boundaries between districts but simultaneously removed internal barriers to mobility and trade (Ozouf-Marignier). 


\section{Conclusion}

This chapter discussed how maintaining slavery alongside the emergence of abolition challenged existing patterns of spatial organization in North America. Recent literature from geography, history, and political science have shown how central imagining the Americas were to rethinking the spatial organization of European societies during the course of the 17th and 18th centuries. This shift could occur precisely because the social environment and physical geography of the Americas required different modes of visualizing imperial forms of power. Once again, in the early 19th century, in contrast to the production of national borders in western Europe, experiences in North Americas offer a different pathway to understanding the emergence of state spatiality in the late 18th and early 19th century. Slavery and abolition impacted practices of state territorialization so that borders began to emerge at the edges of the independent United States as well as between slave states and non-slave states. Slaves, abolitionists, and slave-owners were key actors in this process. They gave meaning to lines drawn on maps by their narrations of spaces of abolition, by their flight, by their violence, and by their legal appeals. In turn, politicians reacted to the results of these actions and sought to balance slavery and abolition in the young republic. I do not seek to examine this struggle to bound spaces of slavery and abolition in order to establish another US exceptionalism. Rather, as European societies in the 19th century struggled to redefine themselves nationally in a new age of empire, that is to establish nation-states in Europe while maintaining or gaining colonial holdings, they did so with knowledge of the US experience in managing state space.

While it is critical from a global history perspective to focus on the shift towards the emergence of territoriality in the mid to late 19th century focused on Europe and its empires, the period following independence in the United States does not point to a clear transition between imperial and nation-state spatial orders (Kumar) whereby the state is demarcated by external borders and an empire is characterized by buffer or boundary zones. Rather, incorporating these contingent border practices helps to demonstrate the instability of this transition as borders, boundaries, and frontiers simultaneously characterized imaginations and experiences of state spatiality (for the co-existence of frontiers and boundaries, see Sahlins). Bordering and "borderlands" research from the American hemispheric context should be taken as seriously as the western European case studies that explicitly or implicitly see borderlands as precursors to state borders. The practices in the Americas, shown in this chapter through the context of slavery in the United States, show how bordering allowed a variety 
of actors to control the boundaries of citizenship, human rights, and property rights (for human rights, see Hunt). This project was not driven by cultural and linguistic considerations as might be seen in the European context. Bounding slavery was key to both delimiting and expanding this institution; furthermore, rather than simply containing state sovereignty, bordering was a tool in state territorialization itself.

\section{References}

Adelman, Jeremy, and Stephen Aron. "From Borderlands to Borders: Empires, Nation-States, and the Peoples in between in North American History." The American Historical Review, vol. 104, no. 3, 1999, pp. 814-41.

Agnew, John. "Borders on the Mind: Re-framing Border Thinking." Ethics \& Global Politics, vol. 1, no. 4, 2008, pp. 175-91.

Agnew, John. Globalization and Sovereignty. Rowman \& Littlefield Publishers, 2009.

Albertone, Manuela, and Antonio deFrancesco (eds.). Rethinking the Atlantic World: Europe and America in the Age of Democratic Revolutions. Palgrave Macmillan, 2009.

Anderson, Benedict. Imagined Communities: Reflections on the Origins and Spread of Nationalism. 1983. Revised ed., Verso, 2006.

Belissa, Marc, et al. "Regards croisés: Les indépendances dans l'espace atlantique, v. 1763- v. 1829." Annales historiques de la Révolution française. Vol. 2, June 2016, pp. 167-98.

Branch, Jordan. The Cartographic State: Maps, Territory, and the Origins of Sovereignty. Cambridge UP, 2014.

Cohen, Patricia Cline. "Statistics and the State: Changing Social Thought and the Emergence of a Quantitative Mentality in America, 1790-1820." William and Mary Quarterly, vol. 38, no. 1, 1981, pp. 35-55.

di Fiore, Laura. "The Production of Borders in Nineteenth-Century Europe: Between Institutional Boundaries and Transnational Practices of Space." European Review of History, vol. 24, no. 1, 2007, pp. 36-57.

Dunlop, Catherine T. Cartophilia: Maps and the Search for Identify in the French-German Borderland. U of Chicago P, 2015.

DuVal, Kathleen. Independence Lost: Lives on the Edge of the American Revolution. Random House, 2015.

Edelson, S. Max. The New Map of Empire: How Britain Imagined America before Independence. Harvard UP, 2017. 
Ferrer, Ada. "Haiti, Free Soil, and Antislavery in the Revolutionary Atlantic." American Historical Review, vol. 117, no. 1, 2012, pp. 40-66.

Fick, Carolyn E. The Making of Haiti: The Saint Domingue Revolution from Below. U of Tennessee P, 1990.

Frymer, Paul. Building an American Empire: The Era of Territorial and Political Expansion. Princeton UP, 2017.

Furstenberg, François. "The Significance of the Trans-Appalachian Frontier in Atlantic History, c. 1754-1815.” The American Historical Review, vol. 113, no. 2, 2008, pp. 647-77.

Geggus, David P. (ed.) The Impact of the Haitian Revolution in the Atlantic World. U of South Carolina P, 2001.

Gillis, John. Islands of the Mind: How the Human Imagination Created the Atlantic World. Palgrave Macmillan, 2004.

Hammond, John C. “They Are Very Much Interested in Obtaining an Unlimited Slavery': Rethinking the Expansion of Slavery in the Louisiana Purchase Territories, 1803-1805." Journal of the Early Republic, vol. 23, no. 3, 2003, pp. 353-80.

Harrold, Stanley. Border War: Fighting over Slavery before the Civil War. The U of North Carolina P, 2008.

Hatter, Lawrence. The Imperial Origins of American Nationhood on the US-Canadian Border. U of Virginia P, 2016.

Hunt, Lynn. Inventing Human Rights: A History. W. W. Norton, 2007.

Jacoby, Karl. Shadows at Dawn: A Borderlands Massacre and the Violence of History. Penguin, 2008.

Kiser, William S. Borderlands of Slavery: The Struggle over Captivity and Peonage in the American Southwest. U of Pennsylvania P, 2017.

Klooster, Wim. Revolutions in the Atlantic World: A Comparative History. New York UP, 2009.

Kumar, Krishan. "Nation-States as Empires, Empires as Nation-States: Two Principles, One Practice?" Theory and Society, vol. 39, no. 2, 2010, pp. 119-43.

Landers, Jane. "Garcia Real de Santa Teresa de Mose: A Free Black Town in Spanish Colonial Florida." The American Historical Review, vol. 95, no. 1, 1990, pp. 9-30.

Maier, Charles. Once within Borders: Territories of Power, Wealth, and Belonging since 1500. Harvard UP, 2016.

Middell, Matthias. "Deterritorialization and Reterritorialization." Encyclopedia of Global Studies. Edited by Helmut K. Anheier and Mark Juergensmeyer. Sage, Vol. 1, 2012, pp. 406-409. 
Middell, Matthias, and Katja Naumann. "Global History and the Spatial Turn: From the Impact of Area Studies to the Study of Critical Junctures of Globalization.” Journal of Global History, vol. 5, no. 1, 2010, pp. 149-70.

Mikesell, Marvin W. "Comparative Studies in Frontier History." Annals of the Association of American Geographers, vol. 50, no. 1, 1960, pp. 62-74.

Miquelon, Dale. “Envisioning the French Empire: Utrecht, 1711-1713.” French Historical Studies, vol. 24, no. 4, 2001, pp. 653-77.

Mukerji, Chandra. Impossible Engineering: Technology and Territoriality on the Canal du Midi. Princeton UP, 2009.

Newman, Richard S. The Transformation of American Abolitionism: Fighting Slavery in the Early Republic. The U of North Carolina P, 2002.

Newman, Richard S. “Lucky to Be Born in Pennsylvania’: Free Soil, Fugitive Slaves and the Making of Pennsylvania's Anti-Slavery Borderland." Slavery \& Abolition, vol. 32, no. 3, 2011, pp. 413-30.

Ozouf-Marignier, Marie-Vic. La formation des départements: la représentation du territoire français à la fin du 18e siècle. Éditions de l'École des Hautes Études en Sciences, 1989.

Palmer, Robert R, and Jaques Godechot. "Le problème de l'Atlantique." Comitato internationale di scienze storiche, Xe Congresso Internazionale, vol. 5, 1955, pp. 175-239.

Parkinson, Robert G. The Common Cause: Creating Race and Nation in the American Revolution. U of North Carolina P, 2016.

Peabody, Sue. "There Are No Slaves in France": The Political Culture of Race and Slavery in the Ancient Régime. Oxford UP, 1996.

Reséndez, Andrés. The Other Slavery: The Uncovered Story of Indian Enslavement in America. Houghton Mifflin Harcourt, 2016.

Richter, Daniel K. Facing East from Indian Country. Cambridge UP, 2003.

Rossignol, Marie-Jeanne. The Nationalist Ferment: The Origins of US Foreign Policy, 1789-1812. Translated by Lillian A. Parrott, Ohio State UP, 2004.

Rutz, Andreas. "Grenzen im Raum-Grenzen in der Geschichte: Probleme und Perspektiven," Grenzen im Raum-Grenzen in der Literatur. Edited by Eva Geulen and Stephen Kraft, Erich Schmidt Verlag, 2010, pp. 7-32.

Sahlins, Peter. Boundaries: The Making of France and Spain in the Pyrenees. U of California P, 1989.

Schoolman, Martha. Abolitionist Geographies. U of Minnesota P, 2014.

Schulten, Susan. "Emma Willard and the Graphic Foundations of American History." Journal of Historical Geography, vol. 33, no. 3, 2007, pp. 542-64. 
Schulten, Susan. Mapping the Nation: History and Cartography in NineteenthCentury America. U of Chicago P, 2012.

Scott, James C. Seeing Like a State: How Certain Schemes to Improve the Human Condition Have Failed. Yale UP, 1998.

Sinha, Manisha. The Slave's Cause: A History of Abolition. Yale UP, 2016.

Spero, Patrick. Frontier Country: The Politics of War in Early Pennsylvania. U of Pennsylvania P, 2016.

Tannenbaum, Frank. Slave and Citizen: The Classic Comparative Study of Race Relations in the Americas. 1947. Knopf, 1964.

Troutman, Phillip. "Grapevine in the Slave Market: African-American Geopolitical Literature and the 1841 Creole Revolt." The Chattel

Principle: Internal Slave Trades in the Americas. Edited by Walter Johnson, Yale UP, 2004, pp. 203-33.

White, Richard. The Middle Ground: Indians, Empires, and Republics in the Great Lakes Region, 1659-1815. Cambridge UP, 1991.

Wong, Edlie L. Neither Fugitive nor Free: Atlantic Slavery, Freedom Suits, and the Legal Culture of Travel. New York UP, 2009. 
Antje Dietze

\title{
Americanization of Show Business? Shifting Territories of Theatrical Entertainment in North America at the Turn of the 20th Century ${ }^{1}$
}

\begin{abstract}
In the period from the 1880s to the 1910s, Canada experienced a strong wave of Americanization of its theatrical institutions. Taking a closer look at these transnational theatrical relations, this chapter revisits the role of the Canadian connections in the process of drawing the boundaries of modern entertainment industries in North America. The first part argues that these developments do not fit in national frameworks or in the concept of Americanization as the transnational export of American cultural products. The consolidation of theatrical industries such as legitimate theater, vaudeville, and burlesque ran along regional lines that crossed national borders and covered parts of both the United States and Canada, including Montreal. Taking the example of large-scale business conflicts in the field of burlesque, the chapter then investigates how entrepreneurs in the city not only actively integrated their businesses into wider North American theater networks, but also challenged the dominance of US-Americans in the industry. These changing spatializations of theatrical entertainment did not only include the transcontinental expansion and subsequent drawing of new regional boundaries within the emerging industries. They also entailed new forms of organizing space, as the business evolved toward increasing centralization, rationalization, and exclusive territorial control.
\end{abstract}

\section{Introduction}

"Canada is the only nation in the world whose stage is entirely controlled by aliens," claimed the Montreal-based theater critic B. K. Sandwell in 1911 (23). Those aliens, of course, were from the United States. While Sandwell overstated the situation in order to advance the cause of the national development of the

1 Acknowledgment: The research for this article was carried out during research stays at the Centre canadien d'études allemandes et européennes (CCEAE) at Université de Montréal (2014/15) and in New York City (2016). They were funded by the German Academic Exchange Service (DAAD) through its program "Postdoctoral Researchers International Mobility Experience" (P.R.I.M.E.) and by the German Research Foundation (DFG) through the Collaborative Research Center "Processes of Spatialization under the Global Condition" (Leipzig University). 
Canadian stage, it is true that Canada had experienced a very strong wave of Americanization of its theatrical institutions. At the turn of the 20th century, many of Montreal's large theaters belonged to one corporation, the J. B. Sparrow Theatrical and Amusement Company (Limited), which booked most of its shows in the United States and was thus one of the principal agents of cultural Americanization in the Canadian metropolis. At a time when live theater reached mass audiences and profoundly shaped urban public spheres, this was far from a marginal issue. Taking a closer look at these transnational theatrical networks in the period from the 1880s to the 1910s, this chapter seeks to revisit some historiographical narratives on Americanization by focusing on the role of the Canadian connections in the process of drawing the boundaries of modern entertainment industries in North America.

Most of the academic literature on the Americanization of popular entertainment focuses on the transnational expansion of US-American culture-the ways and mechanisms in which modern cultural formats that had been developed in the United States were exported and appropriated in other countries around the world. The foundations for growing transnational cultural activity were laid not only with the rise of the United States to the status of a world power, but also with the industrialization of popular entertainment at the turn of the 20th century (Rydell and Kroes; Bakker). Research on cultural Americanization has to take into account these profound changes of US-American culture itself, as noted by the American studies scholar Winfried Fluck:

... the Americanization of modern culture did not begin with these exports. Before an Americanization of other cultures could set in, it first had to take place in American society itself. Or, to put it differently: The process of cultural transformation, for which the term Americanization is used today, does not start with American cultural exports after World War II. It starts with the emergence of a new urban entertainment culture around the turn of the century. Its first "casualty" is therefore American culture itself, at least in the form of 19th century American Victorianism. (242)

Placing the Canadian connections in this framework is challenging, as USCanadian relations in theatrical entertainment have persistently remained in the background. The research literature on the formation of US-American entertainment industries often takes the national framework as given and almost completely neglects their Canadian (and Mexican) extensions. Some literature covers Mexican, US-American, and Canadian theatrical developments, but treats them mostly separately (Londré and Watermeier). The literature on the history of Canadian theater, while acknowledging transnational entanglements, is more preoccupied with the emergence of specifically Canadian or Quebecois theatrical forms and institutions. Attempts to build an integrated transcontinental 
perspective and to analyze US-Canadian theatrical relations in detail are rare (Conolly; Vickery). However, accounts by the historical actors themselves often tend to transcend national perspectives (Leavitt).

Against this background, this chapter takes up the debates about the integration of transregional, trans-American, and transnational perspectives in American studies and in historical research on the Americas and especially Canada (Hoerder; Charles and Wien; Siemerling and Casteel; Dubinsky et al.). There is also a broad debate about the continental integration and the Americanness (Americanité, also in the larger sense of the Americas) of Quebecois culture and identity (Bouchard and Lamonde; Lüsebrink; Bahia). These approaches open the way for taking into account the plurality of spatial entanglements that historical actors created and to reevaluate how these challenge and reshape existing research narratives and methods that often privileged national frameworks.

This reorientation helps to uncover complex spatializations both within and beyond the nation, and can also serve to revisit the notion of Americanization in entertainment history. Scholars in this field have already pointed out that the development of modern entertainment industries was not necessarily restricted to a national framework and that the internal transformation of US-American culture and its cross-border expansion were deeply entangled processes. Taking the example of Broadway theater, Marlis Schweitzer has shown that "at the very moment that the commercial US theatre industry was cohering around Times Square and spinning a network of spider web-like strands throughout North America, it was also reaching aggressively across the Atlantic to establish new connections, partnerships, and business ventures" (5). In a similar vein, Abel et al. have suggested to rethink the role of the nation and the national in early cinema history, making them the object of research and asking how they related to other frameworks and orientations, such as global or imperial ones (2).

This chapter reevaluates the development of theatrical entertainment in North America at the turn of the 20th century, investigating how the business was organized across space and how relevant historical actors perceived and steered this process. Starting with the theatrical situation in Montreal and the role of the Sparrow company in integrating the city into North American theater circuits, it analyzes how the US-Canadian theatrical networks evolved at the time. The first part gives an overview of the industrialization processes in the theatrical field in North America, focusing on legitimate theater, vaudeville, and burlesque. Theatrical entertainment was increasingly centralized and consolidated at the turn of the 20th century. This process resulted in fierce conflicts between competing combinations and trade associations, which are usually understood in terms of the emergence of national entertainment industries. However, the 
consolidation of entertainment markets and booking territories in different theatrical genres followed their own spatial logic. They ran along regional lines that crossed national borders and covered parts of both the United States and Canada, including Montreal.

As a result, all of the territorial transformations and conflicts in the North American theatrical field also played out in the city. They are analyzed in more detail in the second part, using the example of large-scale business conflicts in the burlesque field in which the Sparrow company and its representatives took a very active role. The focus shifts to the ways in which the historical actors themselves understood the relevant spatializations of their business and how they strategically engaged in territorial conflicts. This story is practically unknownburlesque as a "low" form of theatrical entertainment has remained on the sidelines of entertainment historiography. While it has attracted some attention as a female spectacle that allows insights into the transformations of cultural hierarchies and gender representation in the United States, its business side has hardly been studied. ${ }^{2}$

\section{The Theatrical Scene in Montreal and Its Integration into North American Theatrical Circuits}

Montreal had been part of North American touring routes and had hosted European and American stars for a long time. Anglophone and francophone theater companies came to the bilingual Canadian metropolis, sometimes directly from Great Britain or France, but most often from or via New York or New Orleans. From the 1880s onward, when more and more theatrical troupes and stars toured extensively across North America, Montreal became part of consolidated touring routes (Lamonde; Hare; Godin; Saddlemeyer). The city grew quickly at this time, from more than 140,000 inhabitants in 1881 to almost 268,000 in 1901 (and up to over 618,000 in 1921) (Linteau 40, 160), and its entertainment sector expanded as well. While the rapidly increasing number of theater houses in Montreal were mostly owned by Canadians or Montrealers, some of the management lay in the hands of representatives of US-American companies and most of the booking was done through the dominant booking offices in New York and other big US-American cities (Barrière, "Montréal,"La societé; Larrue; Bourassa; Graham). As a result, the majority of theatrical offerings in the

2 The most extensive study on American burlesque theater, including some information on its business organization, is by Allen (Horrible Prettiness). Earlier accounts are from Zeidman and Sobel. 
city were anglophone and came from the United States, although at the time, the francophone population had become the majority in the city (Linteau 45).

This led to the widespread complaints at the time about the Americanization of theatrical live entertainment. The most relevant promoter of modern industrialized forms of American popular entertainment in Montreal was the local theatrical entrepreneur John Bolingbroke Sparrow (1852-1914) (Barrière, "Sparrow”). Beginning in 1879, he had taken over most of the city's large theaters and integrated them into the North American theatrical circuits. From 1884 to 1898, he had joined the circuit of the American entrepreneur Henry R. Jacobs, which included cities in the northeastern United States and Eastern Canada. Jacobs, together with F. F. Proctor, was the pioneer of highly successful forms of popular prized melodrama and vaudeville, and was also among the first to establish theatrical circuits dominated by one owner or lessee (Bernheim, ch. 8; Wertheim 100; Marston). After the dissolution of his partnership with Jacobs, Sparrow took over the Canadian part of the circuit. During the 1890s and 1900s, he acquired or leased most of the important theaters in the Canadian metropolis: the Theatre Royal, the Academy of Music, the Théâtre Français, Queen's Theatre, and Her/ His Majesty's. He also for a while controlled the Toronto Opera House and the Grand Opera House in Ottawa (Barrière, La societé, ch. 4; Dufresne; Larrue). In 1903, he incorporated the J. B. Sparrow Theatrical and Amusement Company (Limited) together with his general manager William A. Edwards and the local merchant David S. Walker ("Public Notice"). The company acquired many of the shows for its theaters from theatrical agencies and cartels in the United States.

This integration of Montreal into larger North American production and distribution networks was made possible by the industrialization and centralization of theatrical entertainment in North America in the late 19th century. New theatrical genres emerged and circulated across the postwar United States and the newly founded Dominion of Canada. ${ }^{3}$ Simultaneously, a fundamental transformation of business organization was pushed forward by a growing need to organize the expanding industry: the introduction of traveling combination companies and the establishment of theatrical circuits and booking combines.

The first step in that direction had been the increasing mobility of theatrical companies. Until the 1860s, North American theater had consisted mainly of resident stock companies, meaning more or less permanent theatrical troupes

3 For general information and overviews of the different popular entertainment genres in 19th- and early-20th-century North America, see Ashby; Butsch; Lewis; Nasaw; Toll, On with the Show. 
that remained attached to a house or went on small-scale tours in a region, and were only occasionally visited by a foreign theater troupe. With the establishment of both the transcontinental railway system and the traveling star system in theater, this model was gradually replaced by traveling combination companies. In his classic account of the economic history of American theater, Alfred L. Bernheim gave a concise definition of the new system:

The traveling combination system is composed of temporary producing units, each organized for one play only, none organically connected with any specific theatre, and the great majority without control over the theatre in which they happen to be playing. Combination companies, instead of being localized as were the stock companies, are organized in a producing center, generally New York City, where they remain while they can attract profitable audiences, after which they visit the available theatres throughout the country. (26)

While these shows were generally put together in the metropolitan centers, most of the money was made on the road. However, the theaters at the stops along the tour were not independent production units any more. House management and show production were now separated from each other, and the business became horizontally integrated across larger spaces (Bakker 23-27).

This process affected not only the field of so-called legitimate theater (playbased, highbrow theatrical performances) and first-class revues and musicals (Bernheim; Poggi; Schweitzer), but also the theatrical genres in the sphere of popular entertainment. The most widespread form of theatrical entertainment at the turn of the 20th century were vaudeville shows. They differed from legitimate theater in that they were not based on a play, but were arranged as a series of short acts that typically included a variety of attractions: song and dance, acrobatics, comedic acts, animal acts, strongmen and strongwomen, magicians, blackface and male or female impersonators, and later also moving pictures. Vaudeville was a very flexible form of performance suitable for wide circulation as the shows could be easily packaged, recombined, and transported (Snyder; Wertheim; Cullen et al.). It had also gained wider audiences after a process of "cleaning up"-meaning the strategy of vaudeville entrepreneurs since the 1880 s to elevate these entertainments from their disreputable origins in concert saloons and variety halls with mostly male audiences and turning them into "polite," inoffensive family entertainment that they renamed "vaudeville." Making these shows attractive for women, children, and middle-class patrons in general represented a breakthrough that turned them into an actual mass entertainment.

A third branch of theatrical entertainment which will be looked at in more detail here was burlesque. Originally meaning a parody or caricature of a wellknown play, story or genre, such as classical plays, historical dramas, or opera, 
it became a distinct form of comedic musical performance. Its aesthetics relied on the transgression of cultural boundaries, the inversion of cultural and social hierarchies (such as high/low, in travesties of the classics or mock-heroic plays), and the grotesque (Allen, Horrible Prettiness 26, "The Leg Business"). This form, like the others, originated in transatlantic exchanges. Victorian burlesque shows came to North America from Britain (Clinton-Baddeley; Schoch; Booth 19698). They became especially popular and scandalous in the late 1860 s, when they had developed a strong emphasis on visual spectacle and on the central role of women who not only comically inverted gender roles and often cross-dressed, but also displayed their bodies, usually their legs in skin-colored tights (Dudden; Allen, “The Leg Business"; Buckley).

During the 1870s, burlesque was Americanized, as it was blended with another American form of entertainment, the minstrel show, which changed its mode of circulation and internal structure. North American burlesques were presented mostly by traveling combination companies that took over minstrelsy's tripartite structure, which consisted of an ensemble introduction followed by a series of individual olios (short acts like in vaudeville) and then a collective finale, often a farce. Instead of featuring men in blackface and playing with racial stereotypes, burlesque now featured women and distorted gender roles, becoming a form of female minstrelsy (Allen, Horrible Prettiness 163-78; Leavitt 308-21; Toll, Blacking $U_{p}$ ). The genre, which typically included a chorus line of girls, became more and more suggestive over time, including raunchy jokes, belly dancing (cooch dance) and, from the late 1910s and 1920s onward, striptease. It was less respectable than the other theatrical genres and catered mostly to male and working-class audiences, but there were also attempts of presenting more "cleaned up," opulent shows, similar to the developments of polite vaudeville, to attract a wider and more mixed audience ("Burlesque"; Allen, Horrible Prettiness 185-93, 221-25; Ashby, ch. 4).

In sum, this step in the development of popular theatrical entertainment included the emergence of new genres, some of them specifically North American. They were more suitable for transcontinental touring and were able to target mass audiences. The increasing differentiation into separate genres resulted in largely different touring circuits and forms of business organization, often with separate houses that catered to different audiences, although interrelations remained.

The third step in the process of industrialization, after the emergence of the traveling combination system and the differentiation of new genres, was the centralization of the theatrical business. With the growth of the theatrical touring networks, competition had increased and booking became more and 
more complicated. To avoid cutthroat competition and booking chaos, house managers banded together to form circuits-groups of geographically related theaters that together formed a favorable touring route. Acting as a group gave them more bargaining power in the negotiations with show producers, and it reduced transaction costs for all involved. Throughout the 1880s and 1890s, many regional circuits developed, often with dominating managers that owned several houses in different cities. These circuits in fact delineated theatrical booking territories, often with exclusive representation of the houses and cities by the circuit (Bernheim 36). These did not align with political borders, but were business territories with very dynamic boundaries. They were not primarily defined by ownership of land or real estate, but were running along the lines first of regular touring activities and then, increasingly, coming under tighter control through booking.

From there, it was only a small step to further integrating and centralizing these circuits by merging the controlling interests of different territories. The field of legitimate theater pioneered this process when a group of powerful US-American circuit leaders, show producers, and booking agents formed the Theatrical Syndicate in New York City in 1896. They agreed on exclusive and central booking across their respective territories, taking control of most of the first-class theaters in North America. The original circuit included 33 theaters from coast to coast, but over the next 15 years it gained direct control or booking dominance over reportedly up to 700 theaters in the United States and Canada (Bernheim, ch. 11). They had followed the examples of the great trust wave in the North American economy at large and of retail chains that had been established to rationalize the sale of consumer goods. The Syndicate was also commonly called the Theatrical Trust although it was not actually organized as a trust. According to Bernheim, it was not incorporated, but a temporary unlimited liability partnership. It only handled booking, while the houses and shows remained in ownership and under the control of the partners (ch. 7). The Syndicate was a highly controversial organization and did not remain uncontested, entering into conflicts with independent producers and managers, with artists' organizations, and soon with an equally strong rival in its field, the Shubert Organization (McNamara; Hirsch).

Similar centralization processes occurred in vaudeville, where ever larger and increasingly integrated circuits were formed. Vaudeville managers from the most powerful circuits in the western, midwestern, and eastern parts of the United States came together to form the Association of Vaudeville Managers (AVM) of the United States, a trade association, in 1900. In contrast to legitimate theater however, the vaudeville field was characterized by a lasting division 
into eastern and western sections, each with a board of managers and its own booking office. The line dividing their territories shifted slightly through the years, but most of the time it was drawn through Chicago or Cincinnati. In 1902, the AVM had represented 62 theaters, while in 1907, its successor, the so-called Combine, included over 200 theaters and booked many more through the eastern and western branch of the United Booking Office (Wertheim 104, 132). The alliance included a territorial agreement defining the boundaries of the eastern and western sections, but grappled with frequent tensions between those sections. Conflicts also arose with independent agents and producers and with the Syndicate and Shubert Organization, who despite their competition undertook attempts together to make inroads into the vaudeville field by opening opposition houses and forming a rival circuit with their own booking system (Schweitzer 20-30; Wertheim 138-48). Just like the conflicts in legitimate theater, the "vaudeville wars" show that while the sector of theatrical entertainment in general had expanded tremendously and became more and more consolidated, it remained highly dynamic and riddled by divisions, business wars, and changing alliances.

Similar to the other theatrical forms, burlesque developed its own forms of business organization, while however remaining a much smaller branch than legitimate theater or vaudeville (Allen, Horrible Prettiness 190-93; "Burlesque"). This included the Traveling Managers' Association (TMA), a trade association of burlesque show producers that had been founded in 1900, and two dominant circuits. The Cincinnati-based Empire Circuit in the West had been incorporated in 1897 and played more suggestive shows. The eastern, New York-based Columbia Circuit later split from the existing organization. It was incorporated in 1902 and started promoting a policy of cleaning up, following the model of vaudeville, while not always fully enforcing it. To book these circuits, a unique touring principle, called "the wheel," had been introduced in 1902. Starting positions and touring routes for burlesque shows were assigned by the drawing of lots before the start of the theatrical season, and then the shows moved along the circuits like spokes of a spinning wheel, playing a new house each week during an entire theatrical season. While in its earlier years, the wheel consisted of roughly 30 to 40 shows and houses for a theatrical season of up to 40 weeks, in 1913 the two circuits booked 67 shows. Initially, two of the wheel houses were in Canada-in Toronto and Montreal. As the circuits grew, more houses were opened, and there were also traveling or stock burlesque shows outside of the wheel. Just like in legitimate theater and vaudeville, the burlesque circuits represented territories that spanned the United States and Canada and included exclusive booking and a ban on opposition. However, the field was engaged 
in almost constant business conflicts, consisting of different "burlesque wars" between the Eastern and Western circuits that ultimately resulted in the split of the wheel.

The increasing consolidation, centralization, and rationalization of theatrical entertainments at the turn of the century allowed for a constant supply of the most qualitative and up-to-date theatrical entertainment in Montreal. All of the important circuits of legitimate theater, vaudeville, and burlesque extended into Canada. Canadian managers were members of the trade associations or combinations, and their theaters and shows were advertised and reported upon in the US-American theatrical trade papers. This is what Sandwell meant by foreign control: Canada had become part of the business territories of the American corporations and cartels and was thus another battle ground for their fierce competition:

None of them can get it out of their heads that the theatres of the United States should be one vast monopoly, and that anybody who is trying to get a share of the theatrical trade should be exterminated. ... What I am concerned with is the fact that Canada is included in the area for which these vast organizations are fighting; that Ontario is as much tributary to the offices on either side of Broadway as is Minnesota, and that British Columbia is parcelled out like New Jersey. (Sandwell 23-24)

From this perspective, Americanization did not merely mean the export of theatrical fare from the United States to Canada. It entailed the full integration of large parts of the Canadian theatrical landscape into US-American theater networks and organizations, with Canadian provinces having largely the same status as US-American states, all of them tied to headquarters in New York City and some other hubs of the industry. However, this was not the result of a "foreign" takeover, but the local managers in Montreal had actively pursued this strategy of integration, for instance, by becoming members of US-based business organizations and combinations in order to gain access to shows for their houses.

\section{The "Burlesque Wars" and the Role of Montreal}

The representatives of the Sparrow company had joined the Theatrical Syndicate and the Columbia burlesque circuit and used not only the booking office of the eastern section of the vaudeville alliance, but also independent vaudeville agencies. At first, they had pursued these affiliations to gain access to the most up-to-date theatrical shows and to successfully fight their competitors within the city, even to expand their reach beyond Montreal. ${ }^{4}$ But the increasing integration

4 Still, Sparrow did not control all of Montreal's theaters. Several more houses, playing either French or English stock companies or a variety of amusements, existed as well. 
into the North American circuits and booking combines also meant that the business conflicts between the combinations in the different theatrical branches started to play out in Montreal. This resulted in the split of the city's theatrical scene into rival circuits and the opening of additional theaters in direct opposition to the existing ones. The situation became especially dynamic in the years between 1904 and 1913, when several of these competitive struggles heated up and intersected. The theatrical entrepreneurs and managers in Montreal were not merely recipients of these conflicts, but active participants, as will be further detailed using the example of the burlesque field.

The business of burlesque theater at the time was ridden with rivalries for profit and dominance between house managers and traveling show managers on the one hand, and between the Eastern and Western circuits on the other. Robert C. Allen noted in his standard work on American burlesque that unlike in vaudeville, where a relatively stable oligopoly was formed,

... no single force in burlesque theater ownership was dominant enough to hold its competing factions in line. Furthermore, in vaudeville, power was inherently invested in theaters and in booking agencies, against which any individual act was virtually powerless. Burlesque was comprised of two much more equally matched forces: theater owners and producers. (Horrible Prettiness 191)

As a result of this power balance, the burlesque business was much more volatile than the other theatrical industries. The period studied was characterized by an ongoing search for ways to stabilize and better regulate the burlesque field. The managers not only had discovered a new mechanism of advancing their business through territorialization, but were also struggling to create the means to steer and control the ensuing uncertainties and clashes.

The "wheel" had been established as a booking system between the TMA and the (western) Empire Circuit in 1902 to regulate the rampant competition and bring order into the booking chaos. This very formalized procedure was introduced by the TMA to balance out conflicts between members who now, at least in theory, were restricted from opening additional houses or produce more shows to increase competition. The wheel was, from the outset, explicitly designed to stabilize the existing booking territory and to protect it from both internal conflicts and outside invasions:

In fact, his endeavors helped to develop the theater scene in the city and in turn fueled reactions to establish other theatrical genres, which were either completely controlled by locals or obtained their productions and theatrical troupes not from the American market leaders, but directly from France or Britain, or from independent agencies. 
The "wheel scheme" is intended to freeze out any future burlesque shows which may appear on the amusement horizon. ... The burlesque houses included in the Empire Circuit, for instance, play a season of thirty-six weeks. What the Traveling Managers' Association wants is for their shows only to be booked over the Empire Circuit to cover the full thirty-six weeks, so that no other "outside trick," which may be born in the future, may book time over the circuit. ... In this way, it is claimed, thousands of dollars in transportation will be saved, to say nothing of erecting another barrier around the already substantial burlesque trust. ("Novel Scheme")

But very soon, the conflicts resumed, especially after the establishment of the (eastern) Columbia Circuit that same year which was also booked by the TMA. The almost constant fights provoked the termination of the joint booking for the Eastern and Western Circuits and a split into two rival wheels in 1905, the TMA remaining with the Eastern Circuit. The circuits engaged in a long and bitter competition, fighting for houses and the success of their respective style of burlesque, as was later described in a promotional brochure published by the Columbia Circuit:

The new company had to grab theatres in a sort of catch-as-catch-can fashion, annexing one here and another there, in the large cities, gradually building up a string of houses in sufficient number to give assurance to producers of a season's engagement on a circuit. As soon as a theatre advantageously and attractively situated became available the Columbia people would bid for it and, if successful, release a less desirable house for other purposes. ("Sam Scribner’s Long Campaign")

The so-called burlesque wars raged on until the Columbia Circuit absorbed the Empire Circuit in 1913, only to engage in new conflicts with newly founded rival circuits in the following years (Allen, Horrible Prettiness, ch. 8; "Burlesque"; Gray and Yates).

The Sparrow company became deeply entangled in the constant clashes about booking territories and exclusive control of theaters in the burlesque field. ${ }^{5}$ Sparrow's Theatre Royal had played burlesque shows since the 1890s. Manager Edwards had become a founding member of the Columbia burlesque circuit in 1902 to secure a continuous supply of good burlesque shows for the Royal, and

5 This account of the burlesque war with reference to Montreal is based on press articles from trade papers including the New York Dramatic Mirror, the New York Clipper, Billboard, Variety, and New York Morning Telegraph; on Larrue; and on testimonies and exhibits in court documents. I have reviewed the court documents for those trials that were held at the United States Circuit Court for the Southern District of New York and at the United States Circuit Court of Appeals for the Second Circuit (National Archives of the United States at New York City). 
later the Théâtre Français, as part of the burlesque wheel. Burlesque was highly successful in Montreal, despite continuous opposition by both the Catholic and the Protestant churches, as well as the temperance movement. These protests did in several instances result in arrests of performers and in legal actions against the shows or the theaters, as well as in campaigns of both the anglophone and the francophone press in the name of the protection of the city's youth (Larrue 62734, 772-73; Dufresne 89-99). But at the same time, burlesque with its strong musical and visual focus and low ticket prizes provided a form of entertainment that integrated a wide social spectrum of patrons and appealed to both the francophone and the anglophone population in Montreal. It thus solved one of the most pertinent problems the theatrical entrepreneurs that engaged in popular mass entertainments had to overcome-the fragmentation of audiences.

However, with the start of the 1904/05 season, the Sparrow company decided to create its own circuit that would not only include Canadian cities, but also extend into the United States. This was a very unusual endeavor in the theatrical field where expansion usually worked the other way around-from the US metropolises into Canada. The contemporaries also noted this, for instance the trade paper New York Morning Telegraph citing an anonymous insider of the wheel convention in New York City in January 1905:

Edwards became ambitious. He obtained control of burlesque theatres in Boston, Providence, Fall River, Albany, Brooklyn and Newark. All this enterprise was a violation of the ironclad agreement of "The Wheel." But Edwards was doing a very fine business at the Theatre Francais in Montreal, and he took the risks, which he fully comprehended. He apparently thought that he could invade the United States and have things pretty much as he pleased. ("One Route")

Edwards had leased the Columbia Theater in Boston and started to acquire other theaters as well. The Sparrow company publicly announced its plan for a music hall circuit playing vaudeville, burlesque, and musical extravaganzas, including Boston, Providence, Montreal, Ottawa, and later Cleveland, Pittsburgh, Chicago, Brooklyn and Philadelphia, and potentially more cities. Their partners were the Theatrical Syndicate, some agents for vaudeville and melodramas, and one of the most important New York music publishing companies, Witmark \& Sons ("The J. B. Sparrow").

As the Eastern managers of the burlesque wheel got wind of this endeavor, they expelled Edwards from their circuit on the grounds that there were already two burlesque theaters of the Eastern Circuit in Boston. The "Constitution and By-Laws of the Association of Managers of the Eastern Circuit of Burlesque Theatres" from December 1901 included the usual ban on opposition theaters, as stated in article XII: "No member of the Association shall operate any burlesque 
theatre of a temporary or permanent character in any city in which members of the Association are now operating ..." (qtd. in Laski 9-10). They also announced that they would refuse to let any burlesque show play at their theaters that had played in Montreal and started to put pressure on the show managers of the TMA to boycott Montreal. The Sparrow company in turn went to court. It sued those managers that did not bring their shows to Montreal individually for breach of contract, and the wheel for conspiracy to intimidate the show managers to break their contracts and ultimately harm the Canadian company's business, asking for damages of $\$ 100,000$. It won a temporary injunction in 1905 at the US Circuit Court of the Southern District of Ohio in Cincinnati where the Empire Circuit had its headquarters. However, the Empire officers made it clear that they would not support the ban, instead siding with the Sparrow company that soon joined this circuit. Sparrow in turn took his legal actions to New York City, the headquarter of the Eastern Circuit, where he sued the Eastern Circuit Association and the TMA at the US Circuit Court of the Southern District of New York and many years of legal battle followed. In the years from 1905 until Sparrow's death in 1914, probably more than a dozen suits were filed and trials held in the United States and Canada on this matter. The whole conflict had also contributed to the split of the wheel, with the Eastern and Western circuits booking independently and entering into a relentless territorial fight over the coming years.

What at first had looked like a conflict between representatives of US and Canadian entertainment companies was in fact a conflict between members of competing US-based associations and corporations for which national boundaries only played a minor role. Their territorial frictions ran along an EastWest division of circuits and booking combinations in a transnational region that extended across the United States and Canada. A closer look at the perceptions and narratives of the historical actors in the trade press, the court depositions, and trials reveals that they not only drew these territorial boundaries according to the logic inherent in their business organization rather than along political borders, but also struggled to understand and control the implications of their own spatializations.

The managers of burlesque houses and touring shows were preoccupied with the expansion and consolidation of theatrical business territories-which they understood as the control of theaters through ownership, lease, management, or booking, combined with membership in the dominant business organizations. The trade press also took this perspective, reporting on the rivalries in the burlesque field as "wars" for territory. A leading officer of the TMA who was quoted in the New York trade paper Daily Telegraph in 1905 even compared the conflicts to the Russo-Japanese War that was being fought at the time: 
This burlesque war was started like the Russo-Japanese difficulty. Each thought the other was encroaching on its territory. Some Western managers tried to break into the East, and some Eastern men were working to get into the Western field. Naturally there was a fight. ("May Close the Burlesque War")

Another example is Rankin D. Jones, the attorney for the Empire Circuit, who testified in 1907:

A. We never went in in [sic] opposition to anybody, that I know of, or anybody's business. We are largely holding on to lines of business that existed before this war.

Q. What do you mean by "this war"?

A. This war that arose in the boycott of Montreal. (17)

While this language drew strong parallels to conflicts over political territory, the term "territory" was also current in business and legal language at the time, referring both to the area in which a company did business and to contractually defined territorial limitations of business activities such as in sales territories. Some of the managers as well as the trade press understood the wheel as a franchising arrangement. The period studied saw not only increased experimentation with different forms of the territorial division of markets and the regulation of competition, but also continuous debates about the legal boundaries of these strategies. With the Sherman Antitrust Act of 1890, the Clayton Antitrust Act of 1914, and the Federal Trade Commission Act of 1914, restricting competition came under stronger scrutiny and also became a topic of contention in the theatrical business. The legal interpretation of the antitrust laws in general, and their application with reference to the entertainment sector in particular, was only clarified by the courts over a longer period of time. An early prominent case was the one against the Theatrical Syndicate for conspiracy and restraint of trade in the New York Court of General Sessions in 1907, where it was determined that stage shows did not fall under the category of commerce that was regulated by the states' antitrust legislation (Schweitzer 22-25). In the late 1910s and the early 1920s, the courts determined in several other cases involving legitimate theater and vaudeville that traveling shows did not constitute interstate commerce and thus were also not covered by the federal antitrust statutes (Flood; Wertheim 233-36). As a result, theatrical combinations and booking conglomerates often escaped antitrust regulations, but the matter remained controversial.

However, during the burlesque war in 1905 and the following years, the direction that the interpretation of antitrust law would take for theatrical entertainment was not at all clear yet. All those involved in the conflict operated under conditions of uncertainty as to the legal conditions of their forms of territorial 
organization. The Cincinnati Enquirer reported that the first suit brought by the Sparrow company in that city alleged a violation of the Sherman Antitrust Act and observed: "The real cause of the action is evidently to declare the alleged boycott off, but if successful Manager Sparrow could eventually be able to upset the entire system of booking burlesque shows through the country under the terms of the agreement now in vogue" ("Suit to Break Up"). This might be the reason why in the court depositions, some of the managers that testified-like Rankin D. Jones cited above-tried to downplay those aspects of their agreements that limited competition or their own role in them. The courts, however, did not treat the matter as an antitrust case and did also not place the territorial conflict at the center of attention. Judge Holt in the trial J.B. Sparrow v. Eastern Circuit Association in the US Circuit Court in New York in 1910 called the ordering of the business by way of the burlesque wheel "an entirely lawful and proper purpose to accomplish" and laid the focus on the question whether there had been a conspiracy or an agreement to injure the business of the Sparrow company by intimidating the show managers to break their contracts ("Charge" 64). The verdict of the jury was in the defendant's favor, but the Sparrow company only received one dollar nominal damages.

The Sparrow company was unable to gain greater influence over the course of the burlesque wars, and did also not succeed in establishing its own music hall circuit. After it had gone over from the Columbia to the Empire Circuit, the Columbia established an opposition house in Montreal-the Gayety Theatre opened in 1912. That same year however, the Eastern and Western burlesque circuits entered into a territorial agreement to reduce the number of opposition houses that had seriously diminished the profitability of the business. As part of this deal, the Empire Circuit agreed to leave the city of Montreal to the Columbia Circuit and its Gayety Theatre, giving up Sparrow and his house. The Sparrow company installed a stock burlesque troupe in the Royal, but soon closed the theater after yet another public campaign against "indecent" performances. In 1913, the Columbia absorbed the Empire Circuit in a \$15 million transaction, and Sparrow died in 1914. New burlesque wars raged on between newly founded rivals, but the golden age of American burlesque was slowly waning and ended in the late 1920s.

During the late 1910s and the 1920s, US-American agencies and corporations retained their strong hold on theatrical amusements in Montreal. However, in parallel to the American-style burlesque shows that continued touring through Montreal, local production of burlesque started and increasingly switched to French-language performances. While these shows did also go on tour, they were produced by resident companies that were tied to a specific theater house. 
By the 1930s, this new variant of burlesque had developed into a separate and very successful francophone form of popular comical acts, toning down the sexualized display of women and turning more into a Quebecois form of variety theater (Hébert, Burlesque au Québec, Burlesque Québécois). In the ongoing process of the respatialization of North American entertainment industries, another regional variant had thus been established, with its own aesthetic style and audience relations, and relying less on forms of territorialization based on consolidated circuits and exclusive booking.

\section{Conclusion}

This chapter argued that the development of theatrical entertainment industries in North America at the turn of the 20th century involved complex spatial logics that do not neatly fit in national frameworks or in concepts of Americanization that focus primarily on the transnational export of American cultural products. It was a multidimensional process involving the creation of specifically North American theatrical genres with particular performance styles, audience relations, and forms of business organization.

When looking at the trajectories of different forms of theatrical live entertainment in North America and at burlesque in particular, instead of a nationalization of the industry followed or accompanied by its cross-border expansion, a different picture emerges. The nationalization, continentalization, and transnationalization of entertainment industries played out in close interrelation. As the example of the Sparrow company in Montreal showed, theatrical managers in Canada were fully integrated into the emerging North American theatrical circuits. Americanization in theatrical entertainment meant the formation of integrated North American theater industries that were organized slightly differently in different theatrical genres due to varying aesthetics, production structures, and audience relations. These did not run along the lines of national or state territories, or of national markets and economies, but formed their own regional geographies of interrelated and competing business territories that spanned across political borders.

The control over these spaces was exercised mainly through booking. The theatrical booking territories were highly dynamic, frequently shifting not only along the lines of the emergence, realignment, and disappearance of the controlling trade associations, corporations, and cartels, but also with every theater that was added to a circuit or taken from it. Many houses were built and acquired; their management, booking affiliation, and the style of shows could change in short order; and the business remained volatile. National borders did at times play a role for the 
North American theater industries-for example, in terms of customs or different copyright regulations in the United States and Canada, and also in widespread references to these circuits as US-American, as they predominantly were on US territory and managed and dominated by US citizens. In this context, a Canadian manager expanding his business to several US cities could temporarily disturb common perceptions. However, in their day-to-day as well as long-term strategic practices, the overall guiding principle of the managers of these circuits lay in the way they balanced out local requirements and the entanglements of transnational regions that extended across the whole continent and beyond.

These changing spatializations of the North American theatrical entertainments did not only include the transcontinental expansion and subsequent drawing of new regional boundaries within the emerging industries. They also entailed changing forms of organizing space, as the theatrical business evolved toward increasing centralization, rationalization, and exclusive territorial control. During this institutionalization process, however, historical actors constantly experimented with different ways to carve out spaces of action and dominance for themselves, operating with a fair amount of uncertainty about the legal basis and strategic opportunities of their activities. Conflicts about any of the theaters on the circuits, or any of the spokes on the wheel, could ultimately lead to profound transformations and reterritorialization processes in North American theater at large.

\section{References}

Abel, Richard, et al. "Introduction." Early Cinema and the "National", edited by Richard Abel et al. Indiana University Press, 2008, pp. 1-7.

Allen, Robert C. “The Leg Business': Transgression and Containment in American Burlesque." Camera Obscura, vol. 8, no. 2, 1990, pp. 43-69.

Allen, Robert C. Horrible Prettiness: Burlesque and American Culture. University of North Carolina Press, 2006.

Ashby, LeRoy. With Amusement for All: A History of American Popular Culture since 1830. University Press of Kentucky, 2006.

Bahia, Márcio. "Americanidad: Towards the Mapping of a Concept." America's Worlds and the World's Americas/Les mondes des Amériques et les Amériques du monde, edited by Amaryll Chanady et al. Legas, 2006, pp. 23-33.

Bakker, Gerben. Entertainment Industrialised: The Emergence of the International Film Industry, 1890-1940. Cambridge University Press, 2008.

Barrière, Mireille. La société canadienne-française et le théâtre lyrique à Montréal entre 1840 et 1913. PhD dissertation, Faculté des lettres Université Laval, 1989. 
Barrière, Mireille. "Montréal, microcosme du théâtre lyrique nord-americain (1893-1913)." Québécois et Américains: La culture québécoise aux XIXe et XXe siècles, edited by Gérard Bouchard and Yvan Lamonde. Fides, 1995, pp. 369-85.

Barrière, Mireille. "Sparrow, John Bolingbroke." Dictionary of Canadian Biography, vol. 14. University of Toronto/Université Laval, 1998. biographi. ca/en/bio/sparrow_john_bolingbroke_14E.html/.

Bernheim, Alfred L. The Business of the Theatre. Actors' Equity Association, 1932.

Booth, Michael R. Theatre in the Victorian Age. Cambridge University Press, 1991.

Bouchard, Gérard, and Yvan Lamonde, editors. Québécois et Américains: La culture québécoise aux XIXe et XXe siècles. Fides, 1995.

Bourassa, André. "Le spectacle de nos contradictions: trusts de production et troupes populaires, puritanismes orthodoxes et folies de fin de siècle, Le théâtre de Québec, 1880-1899 (première partie)." Bulletin d'histoire politique, vol. 15 , no. 1, 2006, pp. 207-26.

Bourassa, André. "Le spectacle de nos contradictions: trusts de production et troupes populaires, puritanismes orthodoxes et folies de fin de siècle. Le théâtre de Québec, 1880-1899 (deuxième partie)." Bulletin d'histoire politique, vol. 15, no. 2, 2007, pp. 129-50.

Buckley, Peter G. "The Culture of 'Leg-Work': The Transformation of Burlesque after the Civil War." The Mythmaking Frame of Mind: Social Imagination and American Culture, edited by James Gilbert et al. Wadsworth, 1993, pp. 113-34.

"Burlesque." Vaudeville, Old \& New: An Encyclopedia of Variety Performers in America, vol. 1, edited by Frank Cullen et al. Routledge, 2007, pp. 158-66.

Butsch, Richard. The Making of American Audiences: From Stage to Television, 1750-1990. Cambridge University Press, 2000.

"Charge." The Court (Holt, J.). Defendant's Exhibits B, C and D. The J. B. Sparrow Theatrical and Amusement Company, Limited v. The Eastern Circuit Association and Others, United States Circuit Court, Southern District of New York, 1910. The J. B. Sparrow Theatrical and Amusement Company, Limited v. J. Herbert Mack, Transcript of Record, Error to the Circuit Court of the United States for the Southern District of New York, 1911, pp. 62-83. Case no. 4356, U. S. Circuit Court of Appeals, Second Circuit, Record Group 21, National Archives at New York.

Charles, Aline, and Thomas Wien. "Le Québec entre histoire connectée et histoire transnationale." Globe: revue internationale détudes québécoises, vol. 14, no. 2, 2011, pp. 199-221. 
Clinton-Baddeley, Victor C. The Burlesque Tradition in the English Theatre after 1660. Methuen, 1952.

Conolly, Leonard W., editor. Theatrical Touring and Founding in North America. Greenwood Press, 1982.

Cullen, Frank, et al. "Vaudeville History." Vaudeville, Old \& New: An Encyclopedia of Variety Performers in America, vol. 1. Routledge, 2007, pp. xi-xxi.

Dubinsky, Karen, et al., editors. Within and Without the Nation: Canadian History as Transnational History. University of Toronto Press, 2015.

Dudden, Faye E. “The Rise of the Leg Show." Women in the American Theatre: Actresses and Audiences, 1790-1870. Yale University Press, 1994, pp. 149-81.

Dufresne, Sylvie. "Le Theatre Royal de la rue Coté: 1851-1913." Travaux et conférences 1975-1979. GRAP/Groupe de recherche en art populaire, Université du Québec à Montréal, 1979, pp. 67-170.

Flood, Gerald F. "The Effect of the Sherman Act upon Monopolies in Amusement Enterprises." University of Pennsylvania Law Review and American Law Register, vol. 72, no. 3, 1924, pp. 293-96.

Fluck, Winfried. “The Americanization of Modern Culture: A Cultural History of the Popular Media." Romance with America? Essays on Culture, Literature, and American Studies, edited by Laura Bieger and Johannes Voelz. Winter, 2009, pp. 239-67.

Godin, Jean-Cléo. "Foreign Touring Companies and the Founding of Theatres in Québec, 1880-1900 and 1930-1950." Theatrical Touring and Founding in North America, edited by Leonard W. Conolly. Greenwood Press, 1982, pp. 89-100.

Graham, Franklin. Histrionic Montreal: Annals of the Montreal Stage with Biographical and Critical Notices of the Plays and Players of a Century, 2nd ed. J. Lovell, 1902.

Gray, Karen R., and Sarah R. Yates. “The Louisville Burlesque War: Empire Circuit Company vs. Columbia Amusement." Theatre Survey, vol. 25, no. 1, 1984, pp. 29-42.

GRAP/Groupe de recherche en art populaire. Travaux et conférences 19751979. Université du Québec à Montréal, 1979.

Hare, John. "Le Théâtre professionel à Montréal de 1898 à 1937." Le Théâtre canadien-français: évolution, témoignages, bibliographie, edited by Paul Wyczynski et al. Fides, 1976, pp. 239-48.

Hébert, Chantal. Le burlesque au Québec: Un divertissement populaire. Editions Hurtubise HMH, 1981. 
Hébert, Chantal. Le burlesque Québécois et Américain. Textes inédits. Presses de l'Université de Laval, 1989.

Hirsch, Foster. The Boys from Syracuse: The Shuberts' Theatrical Empire. Southern Illinois University Press, 1998.

Hoerder, Dirk. To Know Our Many Selves: From the Study of Canada to Canadian Studies. Athabasca University Press, 2010.

"The J. B. Sparrow Theatrical and Amusement Co., Limited (of Canada): Circuit of Music Halls Advertisement”. Sunday Telegraph, 16 Oct. 1904, p. 8.

Jones, Rankin D. "Deposition for Plaintiff." The J. B. Sparrow Theatrical and Amusement Company, Limitedv. The Eastern Circuit Association, George J. Kraus, Samuel A. Scribner, and Others, Circuit Court of the United States, Southern District of New York. Case no. K 6404, Law Case Files 18761906, US Circuit Court for the Southern District of New York, Records of District Courts of the United States, Record Group 21, National Archives at New York.

Lamonde, Yvan. "Naissance et affirmation de la culture commercialisé." Histoire de Montréal et de sa région, vol. 1: Des origines à 1930, edited by Dany Fougères. Presses de l'Université Laval, 2012, pp. 775-99.

Larrue, Jean-Marc. Lactivité théâtrale à Montréal de 1880 à 1914. PhD dissertation, Université de Montréal, 1987.

Laski, Leon, Attorney for Defendant. "Answer." The J. B. Sparrow Theatrical and Amusement Company, Limited v. J. Herbert Mack, United States Circuit Court, Southern District of New York, 1910. The J. B. Sparrow Theatrical and Amusement Company, Limited v. J. Herbert Mack, Transcript of Record, Error to the Circuit Court of the United States for the Southern District of New York, 1911, pp. 8-14. Case no. 4356, United States Circuit Court of Appeals, Second Circuit, Record Group 21, National Archives at New York.

Leavitt, Michael B. Fifty Years in Theatrical Management. Broadway Publishing Company, 1912.

Lewis, Robert M. From Traveling Show to Vaudeville: Theatrical Spectacle in America, 1830-1910. Johns Hopkins University Press, 2007.

Linteau, Paul-André. Histoire de Montréal depuis la Conféderation. Boréal, 2000.

Londré, Felicia H., and Daniel J. Watermeier. The History of North American Theater: The United States, Canada, and Mexico from Pre-Columbian Times to the Present. Continuum, 2000.

Lüsebrink, Hans-Jürgen. "Un état des lieux.” Globe, Revue internationale d'études québécoises, vol. 7, no. 2, 2004, pp. 11-20. 
Marston, William M. F. F. Proctor, Vaudeville Pioneer. R. R. Smith, 1943.

"May Close the Burlesque War." Morning Telegraph, 1 Mar. 1905, p. 10.

McNamara, Brooks. The Shuberts of Broadway: A History Drawn from the Collections of the Shubert Archive. Oxford University Press, 1990.

Nasaw, David. Going Out: The Rise and Fall of Public Amusements. Harvard University Press, 1993.

"Novel Scheme for Routing Burlesque Shows to Be Discussed at the Coming Pittsburg Meeting." Billboard, 23 Nov. 1901, p. 6.

"One Route Is Left Open When the Burlesque Wheel Stops Spinning for Council To-Day." Morning Telegraph, 21 Jan. 1905, p. 10.

Poggi, Jack. Theater in America: The Impact of Economic Forces, 1870-1967. Cornell University Press, 1968.

"Public Notice." Canada Gazette, 18 July 1903, p. 121.

Rydell, Robert W., and Rob Kroes. Buffalo Bill in Bologna: The Americanization of the World, 1869-1922. University of Chicago Press, 2005.

Saddlemeyer, Ann, editor. Early Stages: Theatre in Ontario 1800-1914. University of Toronto Press, 1990.

“Sam Scribner's Long Campaign to Clean Up His Burlesque." Hail Columbia! A Publication of Interest to Theatregoers, vol. 1, no. 1, 1924.

Sandwell, Bernard K. "The Annexation of Our Stage." The Canadian Magazine, vol. 38, no. 1, 1911, pp. 22-26.

Schoch, Richard W., editor. Victorian Theatrical Burlesques. Ashgate, 2003.

Schweitzer, Marlis. Transatlantic Broadway: The Infrastructural Politics of Global Performance. Palgrave Macmillan, 2015.

Siemerling, Winfried, and Sarah Phillips Casteel, editors. Canada and Its Americas: Transnational Navigations. McGill-Queen's University Press, 2010.

Snyder, Robert W. The Voice of the City: Vaudeville and Popular Culture in New York. Oxford University Press, 1989.

Sobel, Bernard. A Pictorial History of Burlesque. Bonanza, 1956.

"Suit to Break Up the Empire Circuit Is Brought in United States Courts." Cincinnati Enquirer, 10 Jan. 1905, p. 2.

Toll, Robert C. On with the Show: The First Century of Show Business in America, Oxford University Press, 1976.

Toll, Robert C. Blacking Up: The Minstrel Show in Nineteenth-Century America. Oxford University Press, 1977. 
Vickery, Anthony. Logistics and Finances of Touring in North America, 19001916. PhD dissertation, University of Victoria, 2001.

Wertheim, Arthur F. Vaudeville Wars: How the Keith-Albee and

Orpheum Circuits Controlled the Big-Time and Its Performers. Palgrave Macmillan, 2006.

Zeidman, Irving. The American Burlesque Show. Hawthorn Books, 1967. 



\section{Transgressing Space: Globalization, Mobility, and Bordercrossings}





\title{
Hannes Warnecke-Berger
}

\section{Salvadoran Transnational \\ Transgressions: Remittances, Rents, and the Struggle over Economic Space}

\begin{abstract}
The massive and ever-increasing amount of remittances circulating between Central America and the United States gave rise to new patterns of economic activities, and thus to an entire new set of economies. In comparison to economic models of the 20th century, this transnational remittance economy does not necessarily rely on state interventions, bilateral trade agreements, or other forms of management of economies. It is not about developing a national economy, but fostering individual well-being. It is not about formulating larger development strategies, but enhancing further remittances in an intrafamily relation based on moral. First, this chapter argues that remittances are rents and create spaces of rent. These economic spaces are based on political power instead of free markets. Then, the chapter explores how different actors intervene in these spaces of rent and thus manage the course of the economy. Next, the chapter analyzes the institutional setting through which these transnational spaces of rents are hedged and argues that the management of the transnational remittance economy releases social pressure from elite activity. Moreover, the chapter explores how and on which particular scale these remittance-induced spaces of rents are politicized in order to capture a share of the flow of rents.
\end{abstract}

\section{Introduction}

El Salvador is located in between North America with its hemispheric hegemonthe United States-and South America. The tiny Central American isthmus links both continental landmasses in geological and geographic terms. The map clearly points out that El Salvador is south of Mexico and therefore it is part of Central America. It is Spanish speaking, has its own national flag and anthem, elects its own president, forms part of the Central American regional initiatives, and of course has its own economy and is known for producing one of the best coffees in the world.

At the same time, however, cultural, political, and economic transnational ties are also highly important for El Salvador. Newspapers maintain a special subsection dedicated to departamento $15,{ }^{1}$ the Salvadoran expatriate community.

1 Politically, El Salvador has 14 departments. The departamento 15 is dedicated to the Salvadoran diaspora in the United States. 
Salvadoran-born US citizens can apply for dual citizenship and participate in Salvadoran national elections. At least the current party in government, the Frente "Farabundo Martî" para la Liberación Nacional (FMLN), maintains a party constituency in Northern California. In economic terms, the Salvadoran community living in the United States produces three times the GDP of El Salvador (Hinojosa-Ojeda). Almost every family has a relative in the United States: more than a quarter of the Salvadoran-born population lives in the United States and many of them send money back home to their families.

Both the geopolitical location and the socioeconomic orientation of El Salvador produce a set of questions, which are particularly relevant to understand the process of spatialization in the Americas: Is El Salvador part of Latin America, or is the tiny society in the Central American isthmus an outpost of the United States? What is its 'place' within the Americas?

For many Salvadorans, migration and remittances are part of their livelihood strategies. As an economy, El Salvador specializes in labor exports and the acquisition of remittances rather than in the production and exportation of commodities. With this changing position in the international division of labor and its microdynamics affecting households coping with daily needs, the Salvadoran economic space is redefined. On a macro level, El Salvador grows into the US economy. Domestic economic processes are increasingly dependent on US economic developments. US labor market dynamics as well as tax and foreign trade regulations have direct effects on households in El Salvador. On a micro level, migrants send a part of their earnings and savings to their families in El Salvador. They expand a monetary circuit, which is not necessarily based on the trade of commodities. While these remittances are part of wages and potential savings of the migrants in the United States, they appear as rents in the hands of families at home.

In this chapter, I discuss the impact of remittances on the Salvadoran economic space. I argue that remittances unfold a contradiction: first, as a macro flow of rent, remittances tend to connect formerly national economic territories, just like traditional commodity or other financial flows tend to do. Remittances transgress national economic borders. In contrast to other economic flows, however, remittances entangle labor markets instead of goods markets. Remittances flows are hard to control. Remittances are private monetary transfers that often escape both state monitoring and state control. Second, as a micro flow of rents, remittances tend to increase the economic autonomy of receiving households. Receiving households are enabled to enhance consumption without necessarily participating in the local labor market. They are able to distance themselves from economic conditions. At the same time, these households struggle to maintain 
remittances and thus strengthen their relationship with the family members living and working abroad. While the micro economic effect of remittances is increasing autonomy, the micro political effect is increasing control to stabilize future remittances.

Finally, I argue that this contradiction has an important implication for the current articulation of economic space. I interpret the development of this particular remittance space as a constant struggle of receiving households to maintain the control over remittances in order to secure their livelihoods. This struggle is getting complex as it involves an increasing number of actors apart from the receivers, such as banks, the government, hometown associations (HTAs), development nongovernmental organizations (NGOs), and international organizations. The chapter shows that this economic space is essentially contested.

The chapter is divided in four parts. First, it discusses the theoretical linkages between economic space and rents as a particular form of economic surplus. Second, it integrates remittances into these thoughts. Third, it shows the volume and the dynamics of remittances in El Salvador on macro as well as on micro levels and their respective influence in shaping economic space. Finally, the chapter turns to the spatial strategies of actors involved in this economic space and how these actors organize access to rents. The conclusion then elaborates on the contradictory role of remittances in both dissolving and restrengthening economic borders.

\section{Rent and Economic Space}

Mainstream economics usually treat space as state-based, essentially capitalist, and as internally as well as externally homogenous. Definitions of economic space, although they remain rather implicit, include a strong but unquestioned relation of space, territory, and state. Economics are about supply, demand, and the market, or about production, consumption, and transaction within a given space usually treated as a state-space. The same is true for rents. While focusing on traditional sources of rent, such as oil and other raw materials or agrarian commodities, rent theory usually highlights the state as the most appropriate institutional setting in acquiring rents (Beblawi and Luciani). State economic space and rents thus become unified in a single concept-the rentier state-space-and both conventional neoclassic economics and political economy approaches to rents tend to highlight the state-space as the primary analytical unit.

In contrast to these theoretically rather pretentious conceptions of the triadic state-territory-economy space, I argue that economic spaces are survival spaces. In the first place, economic space provides the physical necessities for 
human survival, and through this metabolism, human practice appropriates and produces economic space. In this regard, economic space is material. The organization of economic space depends on the availability of economic surplus. Depending on how economic surplus is socially organized, economic spaces are shaped. Hence, I understand economic space as a synchronized spatial relation between the horizontal and vertical division of labor. In a horizontal dimension, economic spaces are topographies of networks of different economic places or locations. These networks evolve because places of production relate to places of consumption. These networked topographies are time-dependent circuits of labor, goods, and money. In a vertical dimension, the division of labor needs to be ordered, spaced, and stabilized, and economic surplus needs to be redistributed, which in the end involves the use of political power. In a strict sense, thus, economic space is always politico-economic (see, for this concept of economic space, Warnecke-Berger, Transnational Economic Spaces).

Economic surplus, the basis of the emergence of economic space, can take the form of rent or profit. In contrast to capitalist profit, economic rents evolve because of market restrictions, monopolies, or political power. ${ }^{2}$ Rent is a surplus earned by "a particular part of a factor of production over and above the minimum earnings necessary to induce it to do its work" (Robinson 102; Elsenhans, "Rente" 439). In contrast to rent, capitalist profit is unique. It depends on additional factors, such as competition among market-dependent entrepreneurs, the predominance of wage labor, and particular wages being paid in economic sectors that do not produce final consumption goods but machinery (Kalecki

2 The concept of rent follows a curious cycle. While it dates back to the ClassicsRicardo, Mill, Smith, and Malthus-and to Marx, it again gained scholarly attention in development studies in the 1960s and 1970s (Khan and Jomo; Schmid). With the demise of development theory and the rise of neoclassical economics, rent theory was mainly understood as rent-seeking (Krueger) and informed theories of the resource curse (see, e.g., Auty). Lately, however, there is a renewed interest in the concept, particularly from geographers (Andreucci et al.; Birch; Elden and Morton; Felli; Haila). However, this renewed interest is predominantly focused on land rent and revolves around the Marxist notion of ground rent. Marx distinguished ground rent, which is a major theoretical pillar of Ricardo's work, from differential rent I and differential rent II. The new interest in land rent is based on the notion of pseudocommodities, as Marxists increasingly recognize that there are high prices for certain goods which do not embody labour power, and thus do not create value following Marx' theory of value. Measured in prices, in contrast, land rent is a specific subcase of differential rent, which is not recognized by this new discussion. Refocusing the theory of rent exclusively on land markets eventually reduces its explanatory power. 
78-79). In this conception, capitalism and capitalist growth depends on rising mass incomes (Elsenhans, "Rising") and on repelling the dominance of rents. In contrast to the more or less accidental development of capitalism, rents are rather ubiquitous. They appear when capitalist mechanisms are too weak or even absent and consequently, when politics dominate economies. When rents are present, political and economic spaces overlap, and social groups and collective actors need to rely on political means in order to access and appropriate economic surplus. When capitalist profit is dominant, in contrast, economic space emancipates from political space since elites become exclusively dependent on market transactions for their own social reproduction and do not need to intervene politically (Wood).

This perspective on both profit and rent as different forms of surplus has particular implications for the notion of economic space. In spaces of rent, the political struggle for access to rents is pivotal. Spaces of rent depend on the political means through which powerful actors realize rents. In turn, the availability of rents creates the ability to exert political control in the first place. Within spaces of rent, the vertical division of labor-hierarchy and stratification-is predominant. Rents tend to verticalize social relations and eventually lead to social closure (Warnecke-Berger, Politics). If rents are available, economic spaces are necessarily and directly infused by political power.

The current world economy is not only challenged by the increasing role of rents (Elsenhans, Saving), but it also experiences a changing composition of its surplus structure. While profits decrease in favor of rents, emerging forms of rent play a more and more important role. Remittances are among these emerging forms of rent (Warnecke-Berger, "La globalisation"). Traditional sources of rent, such as oil or agrarian commodities, are technically based on differential or absolute ground rents. These rents are realized within an institutional structure and usually tend to be appropriated on the national scale. This is one reason why the literature has been overstating the role of the state in approaching rents. In the case of migration and remittances, however, rents are appropriated on other scales than the state. Consequently, "rentier spaces" (Omeje 8) are theoretically disconnected from state-spaces on the national scale. Thus, focusing on remittances as rents in Central America brings about further insights into the economic dynamics of spatialization in the Americas.

\section{Remittances-Led Spaces of Rent}

Perhaps more than ever, Latin America is today connected to the US labor market through the world's largest migration corridor (Dickinson). However, it is not 
just migration, and hence the physical movement of people, that maintains these entanglements. Money flowing back again, sent by migrants to their families, is not only growing, but it is even increasingly becoming a substantial household income for transnational families in countries of origin. On a global scale, the volume of remittances surpasses official development aid and in some places even foreign direct investment. Remittances today are among the top sources of income for developing economies, especially for the economies in Latin America (World Bank).

Narrowly, remittances can be defined as migrants' cross-border monetary transactions to their families who live in the migrant's country of origin. ${ }^{3}$ In a broader sense, remittances are the transnational moral claim of families living apart from the migrant on a part of the migrant's income. This moral claim affects the migrant's propensity to remit. The moral claim generates remittances in the first place. As such, remittances do not appear because of pure altruism, an implicit contract, or competition (which the new economics of labor migration highlights, see, e.g., Stark and Bloom; Stark and Lucas). In contrast, remittances evolve because of individual and often moral, but still political interventions. From the perspective of the sender, remittances are savings. From the perspective of the receiver, however, remittances are rents. Therefore, the impact of remittances on economic space differs from other economic and transnational flows, such as foreign direct investments. It is peculiar in some regard: On the one hand, the appropriation of remittances is tied to particular places where the family and the migrants are still able to impose their ability to control this flow of money. On the other hand, the appropriation of remittances depends on a certain positionality and thus relies on different scales.

First, remittances evolve out of migrations. The root cause for transnational remittances is global nominal wage gaps. These gaps depend on differences in productivity as well as differences in exchange rates. While remittances occur because there are global imbalances, sufficient migrations would in contrast lead to diminishing these imbalances (Radu and Straubhaar). Individually, remittances originate from the income that a migrant worker earns. Without getting indebted, the migrant worker is able to send the actual amount of income minus the subsistence wage at the place where the migrant lives. Remittances thus are potential savings in the host economy which are transferred to other

3 There is an ongoing discussion if remittances invariably need to be monetary transfers. Authors such as Levitt argue for a broader understanding and include other than monetary transfers, such as transfers in kind, as well as immaterial transfers, such as culture and ideas. 
economies where the families live and where these families spend this money. Remittances expand monetary circuits beyond national borders, without necessarily being followed by compensatory commodity flows. In this regard, remittances are transnational debts; they are the moral claim of families in home countries on the migrant's propensity to remit in host countries.

Remittances topographically link the place of production including value generation and the place of the wage bill "here" with the places of consumption and remittance spending "there." Since physical distance separates the migrant and their home family, the situation of earning, saving, and sending money is spatially disconnected from the spending of money. The migrant is not able to fully decide on the spending of remittances, and the home family is not able to entirely determine the amount of money remitted by the migrant.

Both nodes form a translocal moral economy, in which the sending as well as the spending of remittances is negotiated (see, e.g., Paerregaard; and on the concept, e.g., Booth). This translocal moral economy connects particular places where migrants send money from with places to where the migrants send this money (Warnecke-Berger, Transnational Economic Spaces). The enforcement of the family's claim on the migrant's propensity to remit thus depends on weak sanctions and ultimately on communication beyond and across political borders. Technology such as international communications technology intervenes in these translocal moral economies (Hunter; Horst), as it alternates the bargaining position of both the household and the migrant.

However, these moral claims on the migrant's propensity to remit not only depend on the family's capabilities to enforce their claims within the translocal moral economy. They likewise depend on the social situation of the migrant. Since migrants often integrate themselves in social contexts in host countriesperhaps finding better jobs, founding new families, living alternative livesthe propensity to remit usually declines as settlement continues (Waldinger; Schunck). From the point of view of remittance receiver, this potential future loss of income due to declining remittances needs to be compensated by accelerating migration. Maintaining remittances flows then in turn requires increasing migration. In this regard, remittances further stabilize already established migration systems.

While stabilizing and maintaining circuits of human mobility and migration, remittances subdue the borders and boundaries of formerly 'national' economies. At this point, remittances become transnational in its very sense. In contrast to intrafamily financial transfers, such as the financial support for children, remittances are transnational in the sense that they cross already established economic territories and their borders. Nevertheless, remittances are not 
entirely detached from these boundaries since the appropriation of remittances "takes place" at particular locations and within specific spaces. Quite often, these locations are related to the family's living and housing spaces that are the "microterritory" (Bruneau 49) of family life. At these places, remittances are appropriated and redistributed in the first place. In addition to the family, other actors, organizations, and institutions than the sender and receivers of remittances themselves claim to control remittances.

Second, the appropriation of remittances is dependent on the appropriating actor's position related to particular scales. Usually, the family at home captures and appropriates remittances. The economic production and the appropriation of remittances are thus geographically disconnected, but remain within the same scale of translocal families beyond national borders. In this case, the production and the appropriation of remittances are interlinked through translocal moral economies, the most basic node of translocal economic entanglement. However, there are additional forms of appropriating remittances. These forms reach from accessing the place of the home family toward approaching the entire space in which remittances appear. Fig. 7 illustrates the possibilities to appropriate remittances depending on the scale, the location, and the transfer channel.

The figure distinguishes the home country, where the migrant's family lives, from the host country, where the migrant lives (the gray pyramids). Initially, remittances interlink the migrant with the migrant's family. However, as soon as remittances are perceived as an important and beneficial form of income, they are likely to attract the attention of further actors who aim to control these monetary flows. These actors are situated on different scales ranging from the individual to the international, and theoretically dispose of the following spatial forms of approaching remittances indirectly:

- Influencing the propensity to remit: This form is not directed toward appropriating actual remittances, but appropriating potential future remittances and therefore a share of the migrant worker's future income. It depends on either approaching the location where the migrant lives, or, approaching the migrant's family location. A typical example is the NGO's competition for migrant donations or the idea of approaching migrants' philanthropy in the case of diaspora bonds (Ketkar and Ratha).

- Influencing transaction costs: Depending on the market structure among remittance operators including commercial banks, these actors are able to impose fees and therefore to gain access and to appropriate a part of the remittance flow. On average, remittance operators were able to impose 8 percent 


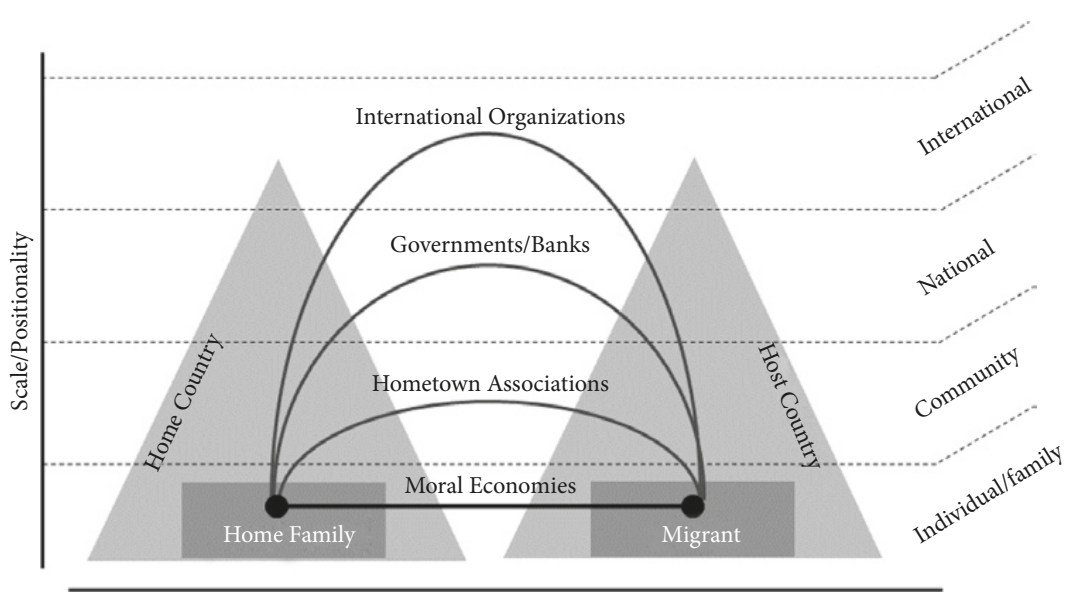

Location / Place

Fig. 7: The Transnational Remittances Economy. Source: Own elaboration

fees on the volume of world remittances in 2016. The income from such fees accounted for more than $\$ 48$ billion (World Bank iv).

- Influencing the propensity to spend: A final form consists in approaching the destination of remittances and channeling remittances into 'productive' purposes. Changing the spending behavior of remittance-receiving households, involves financial literacy and financial inclusion programs (Anzoategui et al.) or micro credits (Mader), HTAs (Lacroix; Orozco, Migrant; Waldinger et al.) and political programs mainly focus on approaching the migrant's family's place. Furthermore, states can impose indirect taxes, such as value-added tax, which do not affect remittances directly, but the domestic demand structure that arises out of remittances.

Each of these forms is inscribed in different spatial settings depending on scale/ positionality and place/location as shown in Fig. 7. While these different modes have in common that they need to rely on the support of the migrant and/or the migrant's family and thus are bound to the place where the migrant and/or the migrant's family lives, the articulation of scale is highly different.

As a space of rent, the remittance space is characterized by the constant and ongoing struggle about who, where, and how to appropriate remittances. Each actor's strategy can be situated on particular scales that sometimes contradict each other in the case of conflicting strategies, or sometimes complement each other in the case of coordination. It is a veritable global remittance agenda in 
the making (Cross; Hudson). This agenda constructs an institutionalized spatial setting, a global economic remittance space, in order to control and to challenge the remittance flow.

Thus, as it was already argued regarding rents in general, the remittance rent space is highly interwoven with political power. Power intervenes in economic issues in order to appropriate and to control the flow of rents. However, power is situated on different scales and inscribed in different spatial settings. In the case of the migrant-family nexus, power relates to enforcing the moral claim on the propensity to remit and thus to shape the translocal moral economy. In the case of HTAs, power relates to the capability to convince migrants and their families of the developmental impact of their philanthropic projects. In the case of governments, power to appropriate remittances is inscribed in the institutional setting of the state.

The specifics of the remittance rent space, however, lie in the fact that remittances are hard to control within a fixed institutional setting. While in the case of classic sources of rent, such as mineral or agrarian commodities, the control of territories is pivotal, in the case of remittances, the control of economic behavior is crucial. Because of already existing migration channels as a precondition for remittances, the political means to control remittances are likely to remain weak and soft. This reflects the often described pro-poor nature of remittances as a new development mantra (Kapur).

Seen from this political economy perspective on remittance-led rent spaces, remittances are able to transgress formerly national economic spaces. Remittances are hard to control in a fixed institutional setting and therefore tend to escape from being appropriated directly by the state. However, in the following, the case of El Salvador shows that remittances indeed are controlled and that these modes of control are contested. Receiving families and households in El Salvador are able to emancipate from local economic conditions, but in doing so, they become increasingly dependent on US economic dynamics. Furthermore, a constant struggle has arisen in recent years over the control and the appropriation of these migration dollars.

\section{From Coffee to Remittances: El Salvador's Economic Transgressions}

The Salvadoran economic space has always been dominated by rents. However, remarkable shifts took place concerning the composition of rent. El Salvador changed from an agrarian commodity producer, and thus from the appropriation of differential rents, to an exporter of labor. At the end of the 19th century, 
El Salvador came to be known for its delicious coffee. Within several decades, it exclusively specialized in the production and the exportation of coffee, and the crop became the sole social, economic, and political engine of the country for much of the first half of the 20th century (Bulmer-Thomas; Dunkerley). Coffee came to be seen as the national wealth of the country, and a tiny oligarchy appropriated much of this wealth (Suter). Since the social situation increasingly sharpened due to oligarchic extravagance paralleled by the deprivation of the masses, and since socioeconomic exclusion, landlessness, and urban squatting became endemic, finally, a political conflict emerged. Beginning in early 1981, the FMLN openly challenged the oligarchy's power and entered the civil war. As common to every Marxist guerrilla organization, the FMLN intended to redistribute the national fruits of the economy. This conflict led to a 12-year civil war that cost the lives of some 75,000 Salvadorans. The civil war devastated the country, and forced thousands to abandon their homes. Eventually, the war ended in 1992 when the warring parties signed peace agreements.

Due to the bloodshed and economic deprivation, outmigration began in larger quantities during these years of conflict and crisis. Particularly within the war-torn departments of Morazán and Chalatenango, families escaped the civil war and emigrated to the United States (Montes). With changing political realities and the approaching peace, the rationale shifted from flight to economics (Funkhouser). It was at this point that remittances began to accelerate. Today, around one-fifth of the national population lives in the United States. Almost every Salvadoran family has an absentee migrant in the United States, and more than 20 percent of Salvadoran households receive remittances on a regular basis (DIGESTYC).

\subsection{Stability of Remittances on the Macro Level}

From the period when the civil war began in the early 1980s until recently, El Salvador entirely shifted its development model. While it had become initially integrated into the world economy as a commodity producer, it now serves as a labor reservoir for the US labor market. While coffee had been dominating the economy as the number one export item, coffee is almost insignificant today. The structure of foreign exchange earnings shows that contemporary El Salvador is more than ever dependent on remittances.

Fig. 8 shows the structure of export earnings in 1978 and 2015. El Salvador was still specialized in traditional agrarian exports in 1978, which then accounted for more than 73 percent of foreign exchange earnings. By 2015, however, traditional agrarian exports had slumped to little more than 5 percent. In the meantime, 


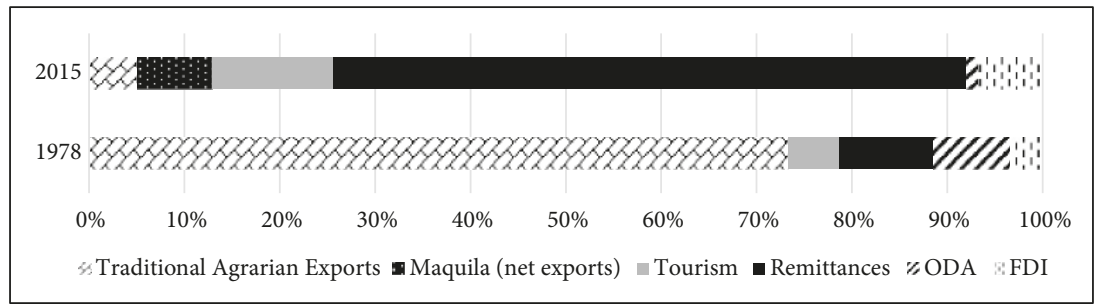

Fig. 8: Structure of Foreign Exchange Earnings in El Salvador, 1978 and 2015. Sources: IMF Balance of Payments Statistics, various years; BCR; OECD Stat; UNCTAD Stat

remittances appeared as the leading income category. In 1978, remittances accounted for only 9.9 percent. In 2015, remittances reached more than 66 percent, followed by tourism and maquila exports. El Salvador thus specializes in the export of labor and the recruitment of remittances (Gammage). Without remittances, the Salvadoran economy would simply implode.

Fig. 9 shows the volume and the share of remittances in relation to GDP entering El Salvador. Apart from the short break during the world financial crisis in 2008, remittances prove to be continuously growing. According to the World Bank (World Bank), El Salvador is today among those societies with highest remittance inflows, in terms of both share of GDP and per capita. Remittances excel multiple times official development aid, foreign direct investment, and are even higher than commodity and service exports. In 2016, remittances accounted for more than 4.5 billion US dollars, which formed 17 percent of GDP (BCR). Because of their huge impact on the domestic economy in terms of comparative trade advantages, El Salvador has become dependent on remittance inflows.

Remittances thus connect Salvadoran migrants in the United States with their families back in El Salvador. They link the reproduction of the labor force in El Salvador with the production sites in the United States, from where remittances originate. Salvadorans in the United States send an average of 37.7 percent of their earnings back home to El Salvador (Yang 133). This is a considerable share of the earnings, particularly when taking into consideration that about half of Salvadoran migrants in the United States are undocumented and are thus exposed to precarious job conditions and lower earnings than documented workers (Casillas). Nevertheless, remittances remain stable and even increase on the macro level, and with remittances, the Salvadoran economy grows into the US economy. 


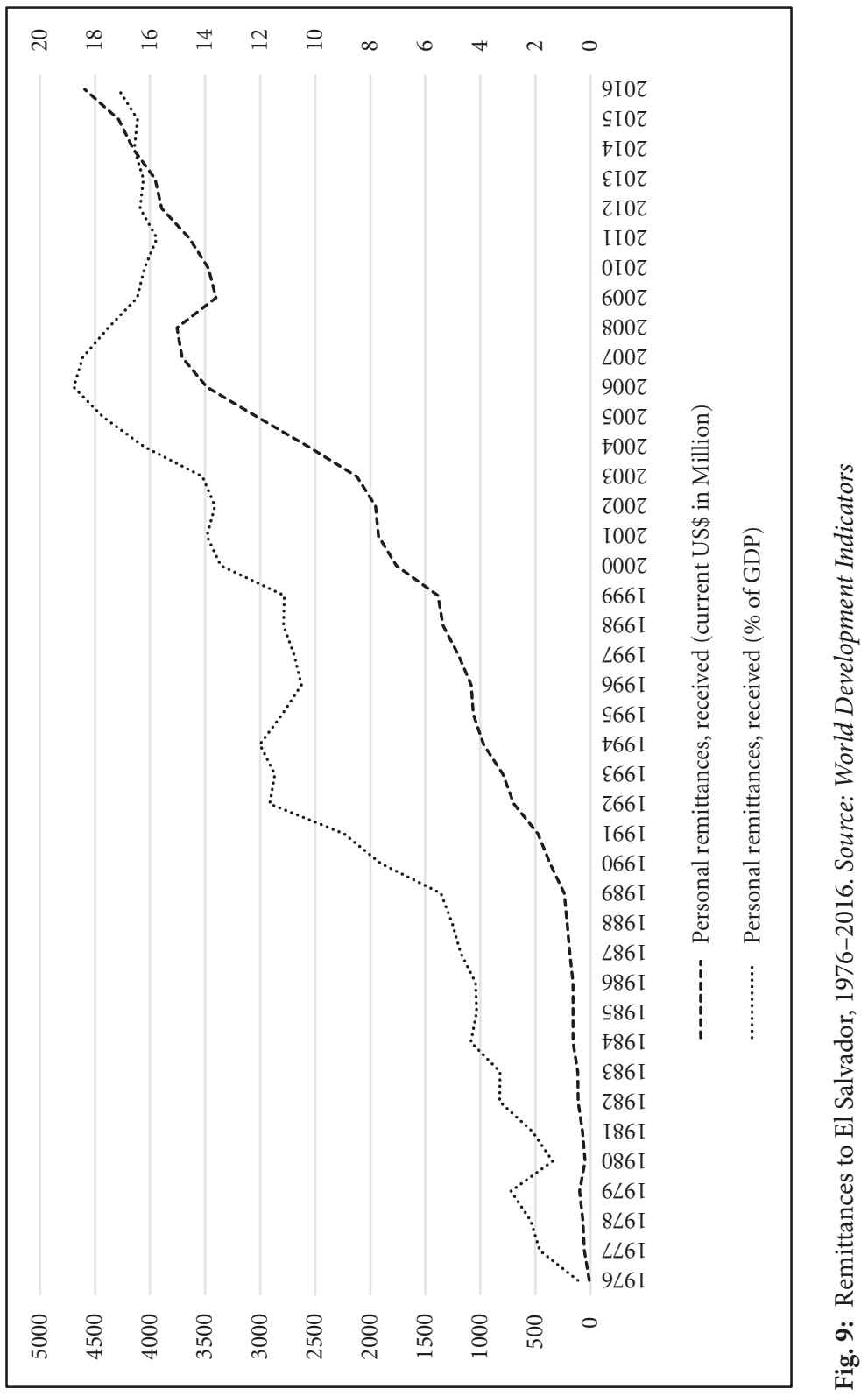


Tab. 1: Distribution of National Income and Remittances in El Salvador, 2015. Source: Author's calculation based on DIGESTYC

\begin{tabular}{lclll}
\hline & $\begin{array}{l}\text { National } \\
\text { Income (\%) }\end{array}$ & $\begin{array}{l}\text { Households Receiving } \\
\text { Remittances (\%) }\end{array}$ & $\begin{array}{l}\text { Total Remittances } \\
(\%)\end{array}$ & Mean (\$) \\
\hline Q1: (poorest) & 4.1 & 34.3 & 40.1 & 221.9 \\
Q2 & 9.4 & 18.8 & 16.5 & 173.0 \\
Q3 & 14.7 & 17.1 & 14.0 & 162.7 \\
Q4 & 22.4 & 15.3 & 14.8 & 188.3 \\
Q5: (richest) & 49.4 & 15.5 & 14.6 & 189.7 \\
\hline
\end{tabular}

\subsection{Pro-Poor Distribution of Remittances}

Following the latest statistical surveys, more than 20 percent of the total population received remittances in 2014 (DIGESTYC). The average remittancereceiving household obtained more than $\$ 195$ per month, which represents around 50 percent of the average household income. The vast majority, over 90 percent of all recipient households, report that they use remittances to cover their daily expenditures (Keller and Rouse).

Tab. 1 shows the distribution of remittances in El Salvador. The table demonstrates that even though income is highly unequal, and the richest quintile receives almost 50 percent of national income, remittances are pro-poor. The poorest quintile receives more than 40 percent of total remittances. Within this poorest income quintile, more than 34 percent of households receive remittances, while within the richest quintile, only a little more than 15 percent of households receive remittances. Likewise, the poor receive on average more remittances than the richer quintiles. Thus, the poor benefit from remittances disproportionally. At the same time, the poor need remittances predominantly to cover their livelihoods (Keller and Rouse) and are unable to afford saving or investment. But even in the case of higher income quintiles, remittances are mainly directed toward final consumption. Remittances thus make receiving households more independent of local economic conditions. These households are able to increase consumption, invest in education and health, and even reduce labor market participation (Acosta). However, this makes them even more dependent on future remittance inflows to cover daily expenditures. Particularly this dependence is relevant for the articulation of economic space, as this distinguishes remittances from the dependence on commodity exports, which are based on particular production sites. Remittances, in contrast, are the result of translocal intrafamily negotiations about the moral claim on the propensity to remit. 


\subsection{Volatility of Remittances on the Micro Level}

The effect of this translocal moral economy is best seen in the fact that remittance flows to El Salvador are countercyclical. In times of economic hardship or natural disasters such as hurricanes or earthquakes, remittances to El Salvador tend to increase (Mohapatra et al.). Remittances thus mitigate local economic shocks and enable receiving families to insure against economic downturns. However, recent estimations elaborated by the Salvadoran central bank show that increasing competition in the remittance transaction market not only leads to lower transactions fees, which can be interpreted as favorable for migrants and receiving households. However, the same effect of lowering fees led migrants to increase the frequency of transactions. The share of migrants who remitted every month decreased from 59 percent in 2012 to less than 50 percent in 2014. During the same period, migrants who remitted their money every two weeks increased from 15 percent in 2012 to 27 percent in 2014 (Palacios and Hurtado de García, Perfil). While the macro flow of remittances is steadily increasing, on the micro level, remittances appear as highly volatile. Even though the macro flow of remittances ever increases, the volume of transactions increases even faster. The effect of this divergence is that the amount per transaction decreases, while the frequency of transactions increases.

This trend has tremendous effects on receiving households: Those households who depend on remittances in order to cover daily needs now need to readjust their economic activities to their main income category. This eventually translates into shorter planning horizons for their economic activities. Households who can avail themselves of a regular, stable, and continuous income structure are able to project their economic activity for longer time periods. Households with a fluctuating income structure, in contrast, need to readjust their livelihood strategies to ever shorter periods. Thus, not only the volume and the individual amount of remittances received are crucial to understand, but the frequency and the dynamics of transactions also affect the economic behavior of receiving households. In El Salvador, the increasing frequency of remittances leads to the unpredictability of future remittances, particularly for those who are in need of receiving remittances.

\section{Political Interventions across Borders: Appropriating Remittances}

Apart from the dynamics of remittance flows on both macro and micro levels, the question of who controls and who allocates remittances thus is crucial to understand the formation of economic space in El Salvador. Illuminating the 
political strategies of rent channeling further highlights that this remittance-led space of rent is highly interwoven with political power. This becomes particularly evident in strategies of politicizing remittances within the United States. In 2004, for instance, when Salvadoran presidential elections approached, US congressional representative Tom Tancredo (R-CO) stated that

$[\mathrm{u}]$ nder an FMLN Presidency, the United States government would not have a reliable counterpart to satisfy legitimate national security concerns. Therefore, if the FMLN takes control of the government in El Salvador, it may be necessary for the United States authorities to examine closely and possibly apply special controls to the flow of 2 billion dollars in remittances from the United States to El Salvador. (Congressional Record 2004, E389, qtd. in Coutin 94)

In a general sense, however, attempts to control economic space in El Salvador have individualized over the last decades. Commodity exports, particularly in the case of coffee, involve fixed capital, land, labor, and commercial as well as merchant facilities in order to extract surplus and realize rents in monetary terms. In the case of remittances, as it was already discussed above, the extraction of surplus remains within transnational families and bounds to communication and weak sanctions, hence to a translocal moral economy.

In this regard, it is no surprise that the vast majority of remittances accrue in the hands of the receiving families. Virtually, this is the very nature of remittances. By remitting money back home, migrants show love. Regular money flows as well as gifts or treats for children are similar attentions (Kent 94). However, both remitting and spending of remittances are contested and both processes take place at different places. The migrant is able to decide on the propensity to remit, but not on the propensity to spend. The contrary is the case for the receiving household. Larger differences emerged between the migrant and the family concerning the allocation and spending of remittances. While migrants tend to prefer savings and investment, families in El Salvador spend remittances for consumption (Inchauste and Stein 56). While migrants often state that they feel like "golden cows being milked" by their Salvadoran families at home, as a Salvadoran migrant stated in an interview in San Francisco, the home families often accuse their migrants of being "parsimonious" or "selfish" (Focus Group Discussion). The arrangement of this translocal moral economy thus affects the "horizontal" redistribution of remittances between the migrant and the family in El Salvador. However, the translocal moral economy essentially remains on the same scale. Even though they influence this "horizontal" redistribution of remittances, migrants as well as households in El Salvador struggle against "vertical" incentives of actors situated on other scales. 
Many migrants have collectively organized in order to finance small development projects in their hometowns. These migrant philanthropic organizations and HTAs have developed in line with a highly vibrant Salvadoran diaspora network in the United States since the 1980s (Menjívar). In general, HTAs exist isolated from each other and distant to the Salvadoran government and its dependencies in the United States (Baker-Cristales). They are mainly focused on isolated development projects to support their communities. Many of these HTAs are able to raise considerable amounts of money in times of crisis or natural disasters in El Salvador, but find it problematic to maintain an organizational structure on an everyday basis, as a former HTA leader explained in an interview (Leiva). In this regard, HTAs resemble common small-scale development NGOs (Elsenhans and Warnecke-Berger). Although situated on a higher scale, HTAs reinforce the rent character of remittances, as they direct their funds not only to economic development and efficiency, but also to increase the personal prestige, as a successful San Francisco-based HTA leader explained in an interview:

Cuando tu trabajas en una organización algunas veces haces el trabajo porque te pagan, y aquí en esto tú haces y dedicas tu tiempo realmente, trabajas quizás más que cualquiera que trabaja en una organización de esas porque estas tan metido, ahora hay una recompensa, no todos lo vemos así, a mí no me interesa mucho pero es válido: es que al fin y al cabo en las comunidades tuyas tenés un reconocimiento de la comunidad. Antes vos llegabas y “¡Aahh! ¡Salud! Ahí va Martin”, hoy llegas “¡Oh! Hola que tal, como está, mire venga siente...” Te dio un prestigio, imagínate en un cantón, esta persona que empezó a hacer algo, buscar cómo llevar agua al cantón, cuando llega: "ahí viene don Fulano", ya es conocido, ya "venga un cafecito". Y eso es estatus pues, y a lo mejor eso es lo que inconscientemente buscamos, de sentir que estamos haciendo algo loable. (Martínez)

In 2000, migrants sent up to 30 percent of remittances through informal channels. By 2014, almost 95 percent of remittances flowed through the formal banking system (Palacios and Hurtado de García, Remitentes). Within the same period, fees were reduced dramatically to less than 4 percent. Thus, the share of money that the banking system was able to capture was increasingly reduced. Official banks as well as international organizations such as the Inter-American Development Bank (IADB) or the World Bank recognized that the direct canalization of remittances almost immediately affects the translocal moral economy, and migrants tend to use more informal channels to withdraw their money from being controlled by other actors than the family. In an interview, Maria Luisa Hyman, an IADB official concerned with the development and implementation of development projects acknowledged that many former projects intended to reallocate remittances directly into development, but eventually failed because migrants and households ceased to cooperate. Instead, the IADB 
llegó a la conclusión que, y además como uno de nuestros objetivos principales es el tema de inclusión financiera, se llegó a la conclusión que una oportunidad era poder ofrecerles a las personas que reciben remesas educación financiera, trabajar con instituciones financieras para que les pudieran ofrecer productos de ahorro que después les sirvan para pagar gastos o inversión, como lo quieras ver, en educación, en salud. (Hyman)

The financial system thus reacted with two innovations. Instead of tackling remittances directly, banks as well as development projects accessed the micro spaces where remittances appeared. Both diaspora bonds and financial inclusion programs were developed to address the specific needs of either migrants or receiving households. First, diaspora bonds are bonds issued by home governments or commercial banks in order to attract migrant savings and to receive higher credit ratings for receiving cheaper loans on global financial markets (Ketkar and Ratha). In El Salvador, Banco Cuscatlán has been particularly active in offering diaspora bonds until the owner of the bank, former president Alfredo Cristiani, sold the enterprise to CityBank (Orozco, "De los lazos"). Second, financial inclusion has become a major tool not only to get access to remittances, but to include poor segments of the population into the financial system. Today, banks earn less money with remittance transactions than with offering credit lines to remittance receivers, as the CEO of Banco ProCrédit acknowledged in an interview (Proescher), and remittance receivers are able or in the need to balance remittance fluctuations with buying credits and eventually getting indebted (Inchauste and Stein 162). Thus, both strategies are not related to getting direct access to remittances, but to use remittances as an entry ticket to offer further services.

Finally, the Salvadoran government increasingly institutionalized a migration policy to foster migrant-home family relations, as Vice Minister for Salvadorans Living Abroad (Viceministra para los Salvadoreños en el Exterior) Liduvina Magarín (Magarín) expressed in an interview. This includes the right to not only vote for Salvadoran expatriates, but likewise engage in cultural life in foreign countries. However, this policy still remains modest, and even high-ranking government officials, such as the former Salvadoran vice minister of commerce and industry, José Francisco Lazo Marín (Lazo Marín), stated in an interview that an integral political strategy in channeling remittances is and has always been absent. The Salvadoran government still struggles to establish formal links to its diaspora and mainly provides migration assistance. However, since remittances have become dominant in El Salvador, the tax structure of the Salvadoran state has changed. Value-added taxes have risen to over 50 percent of tax income (Schneider). Instead of taxing labor and capital, thus, the state opted for taxing consumption, which is mainly financed though remittances. 
Thus, depending on the scale and the positionality of each actor who intervenes in this transnational economic remittance space, different strategies evolve. While families struggle to resist political interventions from superior scales, they need to calibrate the horizontal distribution of remittances. HTAs, banks as well as governments are then secondary actors within the remittance space. These actors recognized that remittances are hard to access directly. Insofar, these actors have developed means to indirectly capture remittances.

In doing so, they need to localize political access and influence the micro spaces where remittances appear in order to capture a share of the rent. As soon as this access becomes too strong, however, migrants and receiving households tend to resist these interventions. Thus, while on a macro level, remittances tend to entangle the Salvadoran and the US economy and thus create a transnational remittance economy, they tend to atomize the relations between actors on the micro level. Both the transnationalization and the (forced) atomized localization of economic space then goes hand in hand.

\section{The Struggle over Transnational Economic Space: A Conclusion}

Remittances are a clear signifier of "transnationalism from below" (Smith and Guarnizo) and a mode of "transnational living" (Guarnizo). In economic terms, remittances are an alternative form of financial flows such as foreign direct investments and official development aid. Remittances occur as savings in the countries from which they are sent since they arise out of "normal" labor income. In societies to which remittances are sent, in contrast, they appear as rents. This remittance-led space of rent is highly interwoven with political power, and political interventions in order to safeguard, maintain, and even increase future remittances flows are commonplace.

This nature of being both "normal" labor income and rent makes remittances peculiar. They connect established capitalist spaces in the Global North with rentier spaces of today's Global South. They need to be continuously mobilized within a translocal moral economy arrangement that entangles the migrant and the receiving family. In 'practicing' remittances, the family expresses a moral claim on the migrant's propensity to remit, and the migrant expresses a moral claim on the family's propensity to spend this money. Both claims can converge and thus foster translocal moral economies on a horizontal scalar level. However, they can at the same time diverge and thus generate social conflicts.

Both, migrants and home families need to defend their influences against actors at superior scales in order to control and appropriate remittances. This 
makes the entire transnational remittance space conflict-ridden and interwoven with political power.

Seen from this perspective, remittances rather produce transnational spaces of rent and thus reproduce global inequalities that already existed prior to the "lock-in" into this development model. While Salvadoran remittances are generated in the United States, they are spent in El Salvador. However, being able to finance Salvadoran consumption, Salvador has to forego the cost of reproduction of labor power. When the transfers of migrants in the United States back to El Salvador are less than the cost of reproduction of labor in only take off remittances merely describe a new form of debt. It is foremost individual debt, but which is used to finance the reproduction of entire societies. Thus, borders and boundaries change due to these economic processes, but it remains doubtful whether these changes are really in favor of the poor.

\section{References}

Acosta, Pablo. Labor Supply, School Attendance, and Remittances from International Migration: The Case of El Salvador. Policy Research Working Paper 3903. World Bank, 2006.

Andreucci, Diego, et al. "Value Grabbing': A Political Ecology of Rent." Capitalism Nature Socialism, vol. 28, no. 3, 2017, pp. 28-47.

Anzoategui, Diego, et al. "Remittances and Financial Inclusion: Evidence from El Salvador." World Development, vol. 54, 2014, pp. 338-49.

Auty, Richard M. "The Political Economy of Resource-Driven Growth.” European Economic Review, vol. 45, no. 4-6, 2001, pp. 839-46.

Baker-Cristales, Beth. Salvadoran Migration to Southern California: Redefining El Hermano Lejano. University Press of Florida, 2004.

BCR/Banco Central de Reserva de El Salvador. Las remesas familiares cierran 2016 con el monto más alto de la historia y el mayor crecimiento de los últimos diez años. Comunicado de Prensa 4/2017. Banco Central de Reserva de El Salvador, 2017.

Beblawi, Hazem, and Giacomo Luciani, editors. The Rentier State. Croom Helm, 1987.

Birch, Kean. “Towards a Theory of Rentiership." Dialogues in Human Geography, vol. 7, no. 1, 2017, pp. 109-11.

Booth, William J. "On the Idea of the Moral Economy." American Political

Science Review, vol. 88, no. 3, 1994, pp. 653-67.

Bruneau, Michel. Diasporas et espaces transnationaux. Anthropos, 2004. 
Bulmer-Thomas, Victor. The Political Economy of Central America since 1920. Cambridge University Press, 1987.

Casillas, Rodolfo. “The Dark Side of Globalized Migration: The Rise and Peak of Criminal Networks-The Case of Central Americans in Mexico." Globalizations, vol. 8, no. 3, 2011, pp. 295-310.

Coutin, Susan B. Nations of Emigrants: Shifting Boundaries of Citizenship in El Salvador and the United States. Cornell University Press, 2007.

Cross, Hannah. "Finance, Development, and Remittances: Extending the Scale of Accumulation in Migrant Labour Regimes." Globalizations, vol. 12, no. 3, 2015, pp. 305-21.

Dickinson, Eliot. Globalization and Migration: A World in Motion. Rowman \& Littlefield, 2017.

DIGESTYC/Dirección General de Estadisticas y Censos. Encuesta de Hogares de Propósitos Múltiples: 2014. Ministerio de Economía, 2015.

Dunkerley, James. Power in the Isthmus: A Political History of Modern Central America. Verso, 1988.

Elden, Stuart, and Adam David Morton. “Thinking Past Henri Lefebvre: Introducing 'The Theory of Ground Rent and Rural Sociology.” Antipode, vol. 48 , no. 1,2016 , pp. 57-66.

Elsenhans, Hartmut. "Rising Mass Incomes as a Condition of Capitalist Growth: Implications for the World Economy.” International Organization, vol. 37, no. 1, 1983, pp. 1-39.

Elsenhans, Hartmut. "Rente." Lexikon der Internationalen Politik, edited by Ulrich Albrecht and Helmut Vogler. Oldenbourg, 1997, pp. 439-47.

Elsenhans, Hartmut. Saving Capitalism from the Capitalists: World Capitalism and Global History. Sage, 2015.

Elsenhans, Hartmut, and Hannes Warnecke-Berger. "Non-Governmental Development Organizations." Handbook of Non-Governmental Organizations, edited by Aynsley Kellow and Hannah Murphy-Gregory. Edward Elgar, pp. 150-179.

Felli, Romain. “On Climate Rent.” Historical Materialism, vol. 22, no. 3-4, 2014, pp. 251-80.

Focus Group Discussion. San Salvador, El Salvador, 6 Sept. 2016.

Funkhouser, Edward. "Labor Market Adjustment to Political Conflict: Changes in the Labor Market in El Salvador during the 1980s." Journal of Development Economics, vol. 52, no. 1, 1997, pp. 31-64.

Gammage, Sarah. "Exporting People and Recruiting Remittances: A Development Strategy for El Salvador?" Latin American Perspectives, vol. 33, no. 6, 2006, pp. 75-100. 
Guarnizo, Luis E. “The Economics of Transnational Living.” International Migration Review, vol. 37, no. 3, 2003, pp. 666-99.

Haila, Anne. Urban Land Rent: Singapore as a Property State. Wiley, 2016. Hinojosa-Ojeda, Raúl. Empoderamiento Transnacional Salvadoreño: Creación de nuevos mecanismos para el desarrollo de la comunidad salvadoreña y El Salvador. North American Integration and Development Center, University of California, 2016.

Horst, Heather A. "The Blessings and Burdens of Communication: Cell Phones in Jamaican Transnational Social Fields." Global Networks, vol. 6, no. 2, 2006, pp. 143-59.

Hudson, David. "Developing Geographies of Financialisation: Banking the Poor and Remittance Securitisation." Contemporary Politics, vol. 14, no. 3, 2008, pp. 315-33.

Hunter, Alistair. "Empowering or Impeding Return Migration? ICT, Mobile Phones, and Older Migrants' Communications with Home." Global Networks, vol. 15, no. 4, 2015, pp. 485-502.

Hyman, Maria L. Interview by Hannes Warnecke-Berger, 22 Sept. 2016. Inchauste, Gabriela, and Ernesto Stein. Financing the Family: Remittances to Central America in a Time of Crisis. Palgrave Macmillan, 2013.

Kalecki, Michael. Selected Essays on the Dynamics of the Capitalist Economy 1933-1970. Cambridge University Press, 1971.

Kapur, Devesh. Remittances: The New Development Mantra? G24 Discussion Paper Series 29. UNCTAD, 2004.

Keller, Lukas, and Rebecca Rouse. Remittances Recipients in El Salvador: A Socioeconomic Profile. IADB/Inter-American Development Bank, 2016.

Kent, Suzanne. "Symbols of Love: Consumption, Transnational Migration, and the Family in San Salvador, El Salvador." Urban Anthropology and Studies of Cultural Systems and World Economic Development, vol. 39, no. 1-2, 2010, pp. 73-108.

Ketkar, Suhas L., and Dilip Ratha. "Diaspora Bonds for Funding Education." Migration Letters, vol. 8, no. 2, 2011, pp. 153-72.

Khan, Mushtaq H., and Kwame Sundaram Jomo, editors. Rents, Rent-Seeking and Economic Development: Theory and Evidence in Asia. Cambridge University Press, 2000.

Krueger, Anne O. "The Political Economy of the Rent-Seeking Society." American Economic Review, vol. 64, no. 3, 1974, pp. 291-303.

Lacroix, Thomas. "Conceptualizing Transnational Engagements: A Structure and Agency Perspective on (Hometown) Transnationalism." International Migration Review, vol. 48, no. 3, 2014, pp. 643-79. 
Lazo Marín, José F. Interview by Hannes Warnecke-Berger, 2 Sept. 2016.

Leiva, Julio. Interview by Hannes Warnecke-Berger, 16 Aug. 2017.

Levitt, Peggy. "Social Remittances: Migration Driven Local-Level Forms of Cultural Diffusion." International Migration Review, vol. 32, no. 4, 1998, pp. 926-48.

Mader, Philip. The Political Economy of Microfinance: Financializing Poverty. Palgrave Macmillan, 2015.

Magarín, Liduvina. Interview by Hannes Warnecke-Berger, 12 Sept. 2016.

Martínez, Martin. Interview by Hannes Warnecke-Berger, 17 Aug. 2017.

Menjívar, Cecilia. Fragmented Ties: Salvadoran Immigrant Networks in America. University of California Press, 2000.

Mohapatra, Sanket, et al. Remittances and Natural Disasters: Ex-post Response and Contribution to Ex-ante Preparedness. World Bank Policy Research Working Paper 4972. World Bank, 2009.

Montes, Segundo. "Migration to the United States as an Index of the Intensifying Social and Political Crises in El Salvador." Journal of Refugee Studies, vol. 1, no. 2, 1988, pp. 107-26.

Omeje, Kenneth C. "Extractive Economies and Conflicts in the Global South: Re-Engaging Rentier Theory and Politics." Extractive Economies and Conflicts in the Global South: Multi-Regional Perspectives on Rentier Politics, edited by Kenneth C. Omeje. Ashgate, 2010, pp. 1-25.

Orozco, Manuel. "De los lazos familiares a los vínculos transnacionales: El impacto de las remesas familiares en Latinoamérica." Pensamiento Propio, no. 12, 2000, pp. 71-90.

Orozco, Manuel. Migrant Remittances and Development in the Global Economy. Lynne Rienner, 2013.

Paerregaard, Karsten. Return to Sender: The Moral Economy of Peru's Migrant Remittances. University of California Press, 2014.

Palacios, Morena de, and Xiomara Hurtado de García. Perfil de los Remitentes Salvadoreños y Caracterización de las Remesas Familiares desde Estados Unidos. Banco Central de Reserva de El Salvador, 2015.

Palacios, Morena de, and Xiomara Hurtado de García. Remitentes y Remesas Familiares desde Estados Unidos: Una aproximación a las Remesas en Especie. Banco Central de Reserva de El Salvador, 2015.

Proescher, Meik. Interview by Hannes Warnecke-Berger, 16 Sept. 2016.

Radu, Dragos, and Thomas Straubhaar. "Beyond 'Push-Pull': The Economic Approach to Modelling Migration." An Introduction to International Migration Studies: European Perspectives, edited by Jan Rath and Marco Martiniello. Amsterdam University Press, 2012, pp. 25-56. 
Robinson, Joan. The Economics of Imperfect Competition. St. Martin's Press, 1933. Schmid, Claudia. "Rente und Rentier-Staat: Ein Beitrag zur Theoriegeschichte." Staat, Markt und Rente in der internationalen Politik, edited by Andreas Boeckh and Peter Pawelka. Westdeutscher Verlag, 1997, pp. 28-50.

Schneider, Aaron. State-Building and Tax Regimes in Central America. Cambridge University Press, 2012.

Schunck, Reinhard. "Immigrant Integration, Transnational Activities and the Life Course." A Life-Course Perspective on Migration and Integration, edited by Can Aybek et al. Springer, 2011, pp. 259-82.

Smith, Michael P., and Luis Eduardo Guarnizo, editors. Transnationalism from Below. Transaction Publishers, 1998.

Stark, Oded, and David E. Bloom. "The New Economics of Labor Migration.” American Economic Review, vol. 75, no. 2, 1985, pp. 173-78.

Stark, Oded, and Robert E. B. Lucas. "Migration, Remittances, and the Family." Economic Development and Cultural Change, vol. 36, no. 3, 1988, pp. 465-81.

Suter, Jan. Prosperität und Krise in einer Kaffeerepublik. Modernisierung, sozialer Wandel und politischer Umbruch in El Salvador, 1910-1945. Vervuert, 1996.

Waldinger, Roger. "Between 'Here' and 'There': Immigrant Cross-Border Activities and Loyalties." International Migration Review, vol. 42, no. 1, 2008, pp. 3-29.

Waldinger, Roger, et al. "Conflict and Contestation in the Cross-Border Community: Hometown Associations Reassessed.” Ethnic and Racial Studies, vol. 31 , no. 5, 2008, pp. 843-70.

Warnecke-Berger, Hannes. Transnational Economic Spaces, Moral Economy, and Remittances. Working Paper Series des SFB 1199 an der Universität Leipzig 3/2017. Leipziger Universitätsverlag, 2017.

Warnecke-Berger, Hannes. "La globalisation de la rente et la montée de la violence." Naqd: Revue détudes et de critique sociale, vol. 36, 2018, pp. 171-82.

Warnecke-Berger, Hannes. Politics and Violence in Central America and the Caribbean. Palgrave Macmillan, 2018.

Wood, Ellen M. “The Question of Market Dependence." Journal of Agrarian Change, vol. 2, no. 1, 2002, pp. 50-87.

World Bank. Migration and Remittances Factbook 2016. World Bank, 2016.

Yang, Dean. "Migrant Remittances." Journal of Economic Perspectives, vol. 25, no. 3, 2011, pp. 129-52. 


\title{
Sebastian Huhn and Christoph A. Rass \\ The Post-World War II Resettlement of European Refugees in Venezuela: A Twofold Translation of Migration
}

\begin{abstract}
After World War II, approximately 18 million people were uprooted all over Europe. Many of them refused to be repatriated, mainly because they did not want to return to the communist Eastern Bloc. Thus, the International Refugee Organization (IRO) was created within the framework of the just-established United Nations. Between 1947 and January 1952, the IRO resettled more than 1 million refugees and displaced persons (DPs) all over the world. About 17,000 of them were resettled in Venezuela. Although the country was involved neither in World War II nor in the upcoming Cold War, it became one of the most important receiving countries of the resettlement in the Global South. While the IRO's resettlement program has been mainly discussed from the perspective of European History, the chapter first argues to add the perspective of Venezuelan migration politics and history to the analysis of the program to understand the program as a spatialization process within global migration. Second, the chapter emphasizes the need to analyze the agency of refugees and DPs as well as the IRO field officers in the process of the resettlement. How did the involved actors translate the political idea of the resettlement into a solution for their personal needs and political convictions?
\end{abstract}

\section{Introduction}

The end of World War II and the Allied victory over national-socialist Germany resulted in the second modern global refugee "challenge" after what had happened in the context of World War I (Ther 76). Approximately 18 million people were uprooted all over Europe (Gatrell 85). A great number of those people were wrested from their original homes by the National Socialists as forced laborers, prisoners of war, or as inmates in the concentration camps and victims of the Shoah. In addition to those displaced persons (DPs), hundreds of thousands of East European postwar refugees who escaped the Red Army and the Eastern Bloc and thousands of Spanish refugees who escaped Franco Spain scattered all over Western Europe.

The Allies' initial plan after victory was to repatriate the refugees and DPs within a few years (Cohen, In War's 27). It soon became apparent, however, that many of them either refused to be repatriated or could not return to their prewar places of origin for several reasons such as traumas, prior loss of their 
livelihood through destruction or the confiscation of land and property, lack of prospects to be able to establish new livelihoods, or personal fear of either the Red Army and communist Eastern European state institutions or fascist Franco Spain (for the Soviet Union, see Goeken-Haidl). The Western Allies therefore developed another plan: the global resettlement of the nonrepatriated refugees and DPs. The Soviet Union opposed the resettlement idea for comprehensible reasons and still insisted on the plan of forcible repatriation if necessary (Marrus 313-24). It was already known that many refugees and DPs refused to return to the Eastern Bloc, while labor force was low in the Eastern European states as a result of massive human loss during the war. As the Western Allies implemented the plan anyway by founding the International Refugee Organization (IRO) in 1947 within the United Nations framework, the resettlement program is thus also considered one of the first conflicts of the upcoming Cold War (Cohen, In War's; Gatrell 90; Ther 225-35).

Venezuela became a very important player in the resettlement program. With over 17,000 received refugees and DPs via the IRO resettlement program between 1947 and 1951, it was, first, the tenth largest receiving country of the IRO's resettlement program on a global scale and even the third largest in terms of accepted DPs in relation to its own population (IRO 1951: 35; Holborn 433). Second, other than, for example, the United States, France, or the United Kingdom, as a Latin American "peripheral" state it did not have the same moral, historical, or political obligations to participate in the program. Third, it was not yet involved in the upcoming Cold War (like in most Latin American countries this did not become an issue till the United States began its counterinsurgency operations against the socialist Arbenz' government in Guatemala after 1952) and therefore did not have any political reason to help to stabilize Western Europe. Fourth, on the other hand, Venezuela also became one of the most active participants in the program. Other than the larger Latin American receiving political countries Argentina and Brazil, it had become a member of the IRO's General Council (IRO 1951: III) and it was the only Latin American country in the IRO's Executive Committee (Cohen, In War's 201n73). Fifth, measured by population density, Venezuela finally even received more refugees and DPs than Argentina and Brazil. ${ }^{1}$

While the IRO and certain countries such as the United States and Great Britain are considered as active protagonists in research about the resettlement

1 IRO resettled 32,712 people in Argentina, 28,848 in Brazil, and 17,277 in Venezuela (Holborn 433). 
project, neither "peripheral" receiving countries nor the refugees and DPs themselves gain much attention as subjects with agency rather than objects in this process. The resettlement program is an important example of the post-World War II awareness that nation-states were "no longer the most effective frame for social action" (Middell and Naumann 150). However, its history has basically been written as either a history of the internationalizing Global North or an institutional history of the IRO and other agencies instead of a global history.

In much of international research about the resettlement program, the question why, how, and under which conditions countries such as Venezuela did participate is poorly investigated. There was a lack of manpower and population in the country during the 1940s, but this alone does not explain Venezuela's active role and policies. European and US-American research about the resettlement in the Global South ignores dynamics in these receiving countries (and vice versa), but a glance at the Venezuelan research about immigration helps to open a new historical perspective to the resettlement program. Thus, the first aim of this chapter is to discuss Venezuela's perspective regarding the resettlement program. We argue that putting emphasis on the simultaneousness and entanglement of two totally different visions of spatial order or spatial frameworks (Middell and Naumann $155,158)$, and on the reciprocal translation of the political "portal of globalization" (Middell and Naumann 162; Baumann et al.) that the resettlement program had opened, offers a way to understand the resettlement to Venezuela as a country that was involved neither in World War II nor in the early stages of the Cold War. With the analytical category of "portal of globalization," we refer to the fact that it is important to analyze how actors manage global entanglements and thus add a micro-perspective to the very macro-concept of globalization. The category of "translation" thereby acknowledges the fact that the resettlement program was initiated within the framework of the establishing United Nations and against the background of the postwar situation in Europe, but also the fact that Venezuela had to translate this program into its own national political discourse. We thus argue that it is important to write the history of resettlement as global history both to incorporate its margins and to put its center into perspective.

The second aim of this chapter is to argue for a focus on the refugees and DPs themselves as actors who used the resettlement program as a social "portal of globalization" to actively solve their personal crises as well as on the IRO officers on the ground, who translated the resettlement program into a political practice together with the refugees and DPs. Regarding those actors' agency, we introduce the analytical value of historical sources about the practice of negotiating resettlement. Research on the resettlement often neglects the refugees and DPs and the IRO officers as protagonists of the resettlement, who had to translate an 
idea and a set of rules into a practice. The IRO's history is written as the history of either an organization or a political plan, but the DPs and refugees themselves are rather treated as the policy's objects (instead of individuals with agency) and the IRO officers on the ground are vastly underrepresented, too. ${ }^{2}$ The IRO's careand-maintenance documents reveal a lot of information about how the refugees and DPs acted (according to their needs and expectations) within the social space $^{3}$ that the resettlement program provided. The documents disclose how they translated the resettlement program according to their needs. ${ }^{4}$

To emphasize the active role of both Venezuela as a receiving country and the refugees and DPs, we borrow the concept of translation from translation studies' academic debate about cultural translation, the postmodern and postcolonial understanding of translation, and the notion of overcoming the idea of the "proper translation" (Bachmann-Medick 6; see also Buden and Nowotny). First, following Chakrabarty's Provincializing Europe, postcolonial studies emphasized the importance of analyzing the translation of meanings in intercultural settings and to overcome Eurocentrism in this regard (Bachmann-Medick 10). This perspective helps to rethink the resettlement program. Western politicians created a certain set of rules for the resettlement program as a potential solution for what they perceived as the problem or task. This does not mean that certain receiving countries understood the program the same way. If we want to understand the history of the resettlement program from the perspective of migration history, we also need to focus on the translation of the idea by actors (in this case Venezuela) who spoke a different political language and had thus translated the project according to their own political agenda. Second, following a poststructural meaning of translation as proposed by Hall, for example, it is important to note that a certain

2 This observation thereby regards research about the resettlement program, not about the DPs themselves. Their living conditions and their agency in the DP camps has been researched, for example.

3 Social space of the resettlement in this case means that the program provided a space of rules and opportunities in which all participating actors (the DPs and refugees as well as the IRO officers and the representatives of the receiving countries) were able to move according to their economic, social, and cultural capital, in terms of Bourdieu. Some DPs and refugees were able to use economic capital to be resettled or to be able to choose a certain destination, some were able to mobilize social capital in form of relations, and some were able to mobilize cultural capital as they were able to better "sell" themselves or to explain their cases better to the IRO than other DPs and to insist on the processing of their cases in long correspondences.

4 At this point, the personnel files of IRO eligibility officers have not yet been located in the National Archives of France that preserve the remaining IRO files. 
idea is not stable in a positivist sense, but constantly retranslated (BachmannMedick 13). The resettlement plan, its constitution, or the intention of its authors thus does not reveal how and in what political practice it was translated by the two actors involved on the ground: the IRO officers, on the one hand, and the refugees and DPs, on the other. This approach is also linked to the idea of analyzing the migration politics - as resettlement-based on the concept of migration regimes, understood as a complex cluster of actors in asymmetric relations negotiating frameworks for migration and/or integration (Rass and Wolff). We thus aim to test the conceptual potential of translation as a cultural process to better understand what happens in this negotiation.

Thus, the chapter aims to discuss two classes of actors besides the IRO and the Western community. They had developed the IRO's resettlement program as an idea, but without the receiving countries' ability or willingness to translate this project into their own spatial and population planning agenda. Thus, the program could not be implemented the way it was. Furthermore, the idea to move 1 million people following a labor-market-orientated-supply-anddemand logic does not yet reveal how the postwar refugees and DPs (and also its practitioners, the IRO's officers on the ground) acted within those spatial orders and within the social space that the resettlement program had created.

\section{The Birth of an International Spatial Order of Migration after World War II}

The IRO was created in 1947 (after the development of the idea in 1946, by the UN General Assembly as a temporary international organization for the resettlement of the European refugees and DPs (IRO 1951; Marrus 340; Yundt 31-32). Between 1947 and 1951 or January 1952 respectively. The IRO resettled above 1 million refugees and DPs. ${ }^{5}$ Some of them were resettled in Europe, but the IRO also organized the resettlement of approximately 700,000 refugees and

5 The IRO's constitution defined refugees as “(a) victims of the Nazi or fascist regimes or of regimes which took part on their side in the second world war, or of the quisling or similar regimes which assisted them against the United Nations, whether enjoying international status as refugees or not; (b) Spanish Republicans and other victims of the Falangist regime in Spain, whether enjoying international status as refugees or not; (c) persons who were considered refugees before the outbreak of the second world war, for reasons of race, religion, nationality or political opinion.” Displaced Persons were defined as follows: “The term 'displaced person' applies to a person who, as a result of the actions of the authorities of the regimes mentioned in Part I, section 
DPs outside Europe. Over 300,000 of them migrated to the United States, over 180,000 were resettled in Australia, followed by Canada and Israel (Holborn 433). Roughly about 100,000 of the refugees and DPs were resettled in Latin America (Caestecker 533; Holleuffer 131).

The IRO's resettlement program has predominantly been written as either European history or as a history of the internationalizing North. Early academic and political writing about the resettlement program not only highlighted the humanistic approach of the Western Allies but also referred to the space and population planning aspect. Donald Kingsley, director general to the General Council of the IRO from 1949 till 1952, described it in 1951 as follows:

The objective of the governments joining together in the IRO was purely humanitarian. The nature of the problem, however, combined with the techniques developed to solve it, has resulted in the accumulation of practical experience which is applicable to the even larger problem of European over-population. [...] We know also that the millions of "surplus" men, women and children who now burden the relief rolls and lengthen the queues of unemployed across the face of Europe, could and would contribute enormously to the wealth, the strength and progress of the free world if means could be found to transplant them to those broad areas where their talents and skills are in great demand. (IRO 1951: V)

Kingsley's 1951 statement reveals an important contradiction. While praising the "purely humanitarian" approach, what he elaborates is the idea of bringing order into the post-World War II space-or the "free world" in Kingsley's terms-with a great space and population planning policy to distribute population and workforce by establishing an international migration regime. ${ }^{6}$

Academic work focusing on the resettlement program from a perspective of European studies, international diplomacy studies, or international organization studies first picked up the humanitarian aspect. In her pioneering study, Holborn interpreted the resettlement program as an expression of the humanitarian values of the Western community of states. Later however, studies emphasized the importance of the upcoming Cold War to understand the resettlement program (Marrus 340-45; Salomon). Besides the space and population order

A, paragraph 1 (a) of this Annex has been deported from or has been obliged to leave his country of nationality or of former habitual residence, such as persons who were compelled to undertake forced labour or who were deported for racial, religious or political reasons (Constitution of the International Refugee Organization, Annex 1: Definitions-General Principles, Section A: Definition of Refugees and Section BDefinition of Displaced Persons).

6 For our understanding of migration regime, see Rass and Wolff. 
policy another space-related aspect becomes important here: "At the end of the 1940s it was the aim of Western allied policy to build a stable political order [and space] in front of the Iron Curtain" (Holleuffer 129). ${ }^{7}$

\section{The Translation of the European Refugee "Crisis" into a Motor for Venezuelan Nation Building}

The international literature about the IRO's resettlement program's path between humanism and the Cold War basically neglects countries such as Venezuela as active players in the resettlement project. Immigration, however, was already debated as an important motor for development in Venezuela since the early 19th century, independently from European and US-American policies and ideas. ${ }^{8}$ With the successful development and immigration policies of the United States, Argentina, and Brazil in mind, populating the country and especially the countryside became one of the main ideas of a Venezuelan spatial planning policy of national development (Berglund and Calimán 19; Pellegrino 7).

\subsection{Venezuela in the 1940s and 1950s}

In the first decades of the 20th century, the oil boom became the boon and bane of Venezuelan development and nation and state building. The country became the world's number two producer of oil (after the United States) and this brought a lot of money into the coffers of both the state and the private oil industry. At the same time, following the logics of a Dutch disease, national agricultural production eroded as prices for agricultural imports dropped and local farmers could not compete any longer. ${ }^{9}$ As the oil industry offered lucrative direct and indirect employment possibilities, a rural exodus was the consequence (Boeckh;

7 For the geostrategical aspect of the resettlement program against the background of the Cold War, see also Jacobmeyer; Marrus 340-45; Gatrell; Cohen, "Between"; Cohen, In War's; Salomon. Both interpretations of the resettlement program-humanism and politically calculated decisions-are thereby not necessarily mutually exclusive at the end. The less-humanistic pre-resettlement idea of repatriation could have had the same geostrategical outcome of stabilizing social and political conditions on the Western side of the Iron Curtain.

8 Ministerio de Relaciones Interiores de Venezuela (1831): "Memoria y Cuenta," qtd. in Berglund and Calimán 19; translated from Spanish by the authors.

9 For a definition of Dutch disease and its importance in the case of Venezuela, see Burchardt. 
Burchardt). ${ }^{10}$ In 1936, according to the Censo General de Población y Vivienda, the population of Venezuela-a country twice as large as France-comprised about 3.4 million inhabitants (Pellegrino 371). While immigration had been discussed as a population and space planning policy since independence, according to Vernant, between 1832 and 1932 only 100,000 immigrants had come to Venezuela (693). Underpopulation thus became a twofold problem for nation and state building: on the one hand, manpower was short in agriculture and other sectors and on the other hand, population was generally short in the country's rural peripheries and border regions with Colombia and Brazil. Increasing the population therefore more and more became part of the development agenda.

On the political level, Venezuela started a process of state and nation building after dictator Juan Vicente Gómez' death in 1935. His successors Eleazar López Contreras (1935-1941) and Isaías Medina Angarita (1941-1945) initiated this process of social, economic, and political modernization not least by building a modern bureaucracy and formulating national development ideas (Banko 65; Zeuske, Von Bolívar). Under López Contreras, a new constitution was written, and the country's first elections were prepared. In October 1945, the military forces overthrew the government. They were a younger generation of well-educated soldiers of the Unión Patriotica Militar. They established a short-dated military junta-the Junta Revolucionaria de Gobierno-but called for general elections in December 1947. The social-democratic candidate Rómulo Gallegos of the Acción Democrática won those first free elections in Venezuela but was again overthrown by the likewise social-democratic-oriented Junta Revolucionaria de Gobierno in November 1948. In the following 10 years, Venezuela was governed by a nondemocratic but development-oriented military junta (Zeuske, Von Bolivar 389-403). State and nation building was fostered by the plan to strengthen and to modernize national agriculture and to colonize the peripheral areas of the country.

So while Western Europe, the United States, and other countries, on the one hand, and the Soviet Union, on the other, established the international spatial order of the Cold War, Venezuela established a very distinctive national spatial order of a nation-state. The resettlement of European refugees and DPs in Venezuela became the result of a political translation of one spatial order into the other, and playing an active role in the IRO as an international organization

10 The oil industry itself offered employment possibilities, but Anzoátegui, Zulia, and Monagas, the main oil-producing Venezuelan states, also became centers of population, commerce, and suppliers to the oil industry (Pellegrino 184). 
may also have been beneficiary for Venezuela for showing presence in global diplomacy.

\subsection{Translating the Political "Portal of Globalization"}

Director General to the General Council of the IRO Donald Kingsley's institutional memoires (IRO 1951) as well as two of the earliest academic works about the IRO and the resettlement of the European refugees and DPs are the main references for the measurement of the IRO's resettlement till the present. In 1953, the French sociologist Jacques Vernant published the first postwar survey of refugees and global resettlement, The Refugee in the Post-War World (Vernant). Three years later, in 1956, the German-born political scientist Louise Holborn, who had emigrated to the United States in 1934 and later became a professor at the Connecticut College for Women in New London, published The International Refugee Organization (Holborn). The most recent works about refugee resettlement during the early postwar years still refer to these three groundbreaking books, even if we cannot be sure that Kingsley, Vernant, and Holborn were able to access and overview all sources already in the early 1950s and if their cited statistics are accurate in all details. ${ }^{11}$ The few internationally published academic works mentioning resettlement in Venezuela also almost exclusively rely on those three sources regarding the statistical evaluation of the resettlement. Keith Yundt's book about Latin American States and Political Refugees, published in 1988 is one example, and Henriette von Holleuffer's article about the resettlement of European DPs in Latin America another one. Both texts are excellent historical works about the resettlement, but the history of the resettlement has so far mostly been told through the lens of the IRO. From this perspective, Venezuelan immigration policy reads like a reaction to the post-World War II European refugee situation.

From the Venezuelan academic perspective however, the resettlement program just blended into a long history of and political discourse about immigration. Underpopulation, the oil boom, and a strong sense of nation and state building and economic and social modernization resulted in an active immigration

11 We do not intend to diminish the authors' achievements by any means. The three books were and still are groundbreaking and Kingsley's, Holborn's, and Vernant's effort recorded the then-knowledge about the IRO and the resettlement and transferred it to the present. Given that the IRO's mission was planned short-term and that its bureaucracy was quite improvised, a lot of knowledge about the project would be lost today without Kingsley's, Holborn's, and Vernant's works. 
policy since 1935/36, the moment when Venezuelan politics overcame postindependence caudillismo and started developing a nation-state. Venezuela already actively supported European immigration before the establishment of IRO mission in 1947 (Berglund and Calimán; Veracoechea; Pellegrino).

The 1936 Ley de Inmigración y Colonización and the 1937 Ley de Extranjeros allowed for the immigration of not only European agriculturists, stockbreeders but also domestic workers, craftsmen, and engineers. Most immigrants in the late 1930s and the early 1940s came from Spain, Portugal, and Italy. Immigration from Spain was to be especially supported for reasons of language and assimilation, the immigration of nonwhite people was to be prevented as far as possible, ${ }^{12}$ and the immigration of Jews was to be limited but not prevented (Berglund and Calimán 43-44). ${ }^{13}$ In 1938, the Instituto Técnico de Inmigración y Colonización (ITIC) was founded to actively advance and organize immigration. The Medina Angarita government (1941-1945) was also already aware of the European situation and tried to translate it into a solution for Venezuela's lack of manpower. They established the Comisión Nacional de Inmigración with the aim to study how Venezuela could benefit from the expected European exodus (Berglund and Calimán 43-44). The plan to attract European immigration did fail at this moment mainly due to expensive and insufficient transport across the Atlantic Ocean (Berglund and Calimán 43-44; Banko 65). Right after the end of World War II, Venezuela became aware that the moment had come; the "portal of globalization" had opened. In Venezuelan historiography, the end of the war was a sidenote and the fact that the expected moment had come, in which thousands or tens of thousands were uprooted and could be selected as immigrants, was the main storyline. The Venezuelan government did send three missions to Europe after 1945-one to France, one to Italy, and one to Germany-to start

12 Regarding the discussion and the partly racist intellectual ideas about immigration after President Gómez' death, see also Salas (133-35).

13 The cases of the steamboats Königstein and Caribia gained a certain prominence concerning Venezuela's role in granting asylum to Jewish European refugees during the National-Socialist regime. Both ships carried Jewish refugees to the Americas in 1939, hoping for acceptance of the refugees in the British colonies of Trinidad and British Guiana. When the British however denied asylum to the refugees for bureaucratic reasons, Venezuela allowed the Jewish refugees to disembark and granted them asylum (Caestecker and Moore 278). Vernant names the "typical" professions of Jewish European refugees and DPs as the reason for their low number among the immigrants in Venezuela rather than anti-Semitic reasons (687). Most of them weren't farm workers and therefore not among those migrants preferred by the Venezuelan government and missions. 
Tab. 2: Refugees and DPs Resettled in Venezuela 1947-1951. Sources: Holborn 442, Vernant 686.

\begin{tabular}{lcccccc}
\hline Year $^{\mathrm{a}}$ & $\mathbf{1 9 4 7}$ & $\mathbf{1 9 4 8}$ & $\mathbf{1 9 4 9}$ & $\mathbf{1 9 5 0}$ & $\mathbf{1 9 5 1}$ & Total \\
\hline $\begin{array}{l}\text { Refugees and DPs leaving } \\
\begin{array}{l}\text { Europe for Venezuela according } \\
\text { to Holborn }\end{array}\end{array}$ & 2,798 & 8,980 & 1,498 & 2,719 & 1,282 & 17,277 \\
$\begin{array}{l}\text { Refugees and DPs arriving } \\
\text { in Venezuela from Europe } \\
\text { according to Vernant }\end{array}$ & 4,250 & 8,193 & 922 & 2,653 & 1,535 & 17,553 \\
\hline
\end{tabular}

${ }^{a}$ In the case of 1947 the table shows the resettlement between July 1 and December 31. For 1948 to 1951, the reference period is January 1 till December 31. The number Vernant refers for 1951 also includes the January of 1952.

recruiting migrants with adequate training, especially agriculturists, domestic workers, mechanics, shoemakers, cooks, and carpenters (Berglund and Calimán 44). Thus, from the Venezuelan perspective, the resettlement did not start with the Western Allies' resettlement plan and not with the establishment of the IRO. Venezuelans had been in Europe already to attract migrants according to their specific national demands.

The Intergovernmental Committee for Refugees, on the other side, did establish two resettlement reception missions in Latin America in 1946 to investigate options for resettlement operations, one in Venezuela and one in Brazil (Yundt 31). In December 1946, the UN General Assembly approved the IRO constitution. Unsurprisingly, Venezuela voted in favor (32). In 1947, Venezuela signed an agreement with the IRO and did send another recruitment mission to Germany (38). According to Banko, the agreement said that 40 percent of the refugees and DPs to be resettled in Venezuela should be agriculturists, the rest mainly craftsmen and professionals of different sectors (66).

The arrival camps for refugees and DPs were the Hotel de Inmigrantes in El Guarataro, with a capacity to accommodate 450 persons, the Centro de Recepción in Sarría, able to harbor 340 immigrants, and the reception center "El Trompillo" in Güigüe, an old farm turned into a camp that could accommodate 2,500 refugees and DPs (Banko 66). According to Holborn and Vernant, between July 1947 and January 1952 approximately 17,000 to 17,500 European refugees and DPs were resettled in Venezuela through the IRO (see Tab. 2). ${ }^{14}$

14 Banko names June 27, 1947, as the date of arrival of the first ship with 850 refugees and DPs coming from Bremen (probably Bremerhaven) in the harbor of La Guaira (67). 
Without discussing the accurateness of the numbers given, the table shows that the transition from the trienio period of democratic opening between October 1945 and November 1948 to the military dictatorship after the November 1948 coup détat significantly lowered the IRO resettlement for European refugees and DPs in Venezuela, but it did not end the program that was negotiated during the short democratic period. Until the present, it has not been sufficiently investigated why the volume of the resettlement to Venezuela lowered that much directly after the military's takeover of government. One reason may have been the new Venezuelan government itself. The military dictatorship valuated the ongoing immigration differently than the former democratic government and established new policies of immigration. After the November 1948 coup d'état, the ITIC was replaced by the Instituto Agrario Nacional (IAN) that also became responsible for the immigration (Pellegrino 199). One very important change in the context of Venezuela's involvement in the resettlement was that the new government and the IAN began to focus on German immigrants as an "attractive" group of immigrants parallel to the ongoing resettlement (Veracoechea 266-67). Thus, only one and a half years after the IRO's establishment, Venezuela developed a parallel immigration program independently from and contradictory to the resettlement program. Veracoechea also mentions the arrival of a German commission in Venezuela in 1950 that discussed the import of German industry and industrial know-how through the recruitment of German skilled workers as well as negotiations with the German priest Kurt Benach who travelled to Venezuela to discuss the immigration of 30 German families of farm workers.

Another reason could also be the IRO and its position toward the fundamental change in Venezuelan politics. It needs to be further investigated whether the IRO or certain IRO executives criticized the return to dictatorship in Venezuela and did send or recommend fewer refugees and DPs without ending resettlement in Venezuela totally, given that the IRO's main goal still was to dispose the refugees and DPs from Europe and the time to fulfill this task ran out already. Finally, it is of course also plausible that fewer refugees and DPs wanted to be shipped to Venezuela after the country's retransition to a military dictatorship. Having survived the National-Socialist regime in Europe or escaped the authoritarian regime in the Soviet Union or the fascist regime in Spain, the perspective to be resettled to a dictatorship may have been a very bad one. The case of the Hungarian refugee Charles Abaffy may serve as an example to illustrate this point. When Abaffy applied for IRO assistance together with his wife and son in August 1946, he had to answer several questions of the IRO's so-called careand-maintenance form. He wrote that he did not want to remain in Germany. Asked where he wanted to migrate to, he named Canada as his first preference, 
English-speaking countries such as South Africa or Australia as his second choice, and "South-American democratic States" as the third preference. ${ }^{15}$ This easily overlooked remark points out the agency of refugees and DPs in translating the resettlement as a solution for their problems.

It can be summarized that the resettlement regime created to administer the migration of European refugees and DPs to Venezuela cannot be fully explained through the IRO perspective. A broader understanding needs to consider the translation of two totally different but simultaneous spatial orders into that migration regime. The post-caudillismo spatial order of nation building through immigration in Venezuela met the post-World War II spatial order of stabilizing Western Europe as the border region to the Iron Curtain. Both spatial orders followed different logics but both actors-the Venezuelan governments and the Western international community-were able to reciprocally translate those spatial orders into their own ones. Neither humanism nor the Cold War played a role for Venezuela to participate in the resettlement project. The Cold War did not become a political priority in Venezuela till 1953, when president Pérez Jiménez declared the fight against communism a centerpiece of Venezuelan politics (Zeuske, Kleine 157).

\section{The Translation of the Resettlement as a Social Space of Migration}

Until today, research about the European postwar resettlement in general, and therefore also in Venezuela, is based on intelligent guesses in certain facets. The refugees and DPs themselves as protagonists in the resettlement program have barely been investigated so far. Historians and social scientists wrote about the question who those migrants were who came to Venezuela with the help of the IRO, but nobody has yet researched this question in depth. Pellegrino assumes that while the ITIC and the IAN tried to foster the immigration of agriculturists, many refugees and DPs probably claimed to be farmers just to be able to leave Europe (186). Holborn follows this line of reasoning (147). Certain indicators make this assumption indeed very probable. Census data show for example that most immigrants lived either in the Capital district or larger cities and thus suggest that most immigrants did not permanently settle in the agricultural periphery of the country but in the cities (Veracoechea 286). Veracoechea however shows at the same time that the ITIC did establish new agricultural

15 IRO Application for Assistance, Charles Abaffy, 23.8.1946, 3.2.1.1/78861775/ITS Digital Archive, Bad Arolsen. 
colonies in 1947 and 1948 with Venezuelan farmers and European refugees and DPs (263-64). She names at least twelve such colonies.

There are historical sources however that help to reveal both the actual time-space development of the resettlement within Venezuela and the social profiles of the refugees and DPs that were resettled to Venezuela as well as their desires and strategies of migration. First, many of the IRO's embarkation lists are archived in the collection of the archive of the International Tracing Service (ITS) in Bad Arolsen. The same archive holds thousands of IRO records, such as the care-and-maintenance documents-the so-called CM-1 files of the IRO. Refugees and DPs had to fill in those forms to apply for assistance by the IRO. Those files reveal information about who the refugees and DPs were, about their aspired destinations and strategies of migration, as well as about how the IRO's officials on the ground did translate resettlement from idea into practice. Finally, the ITS's archive contains the ITS's tracing-and-documentation files. In case someone requested information about refugees and DPs at the ITS long after the ending of the resettlement program, the archive documented all available paperwork on those persons in these files.

Those historical sources have generally not been systematically looked at, not only for the Venezuelan case. We are currently preparing to investigate those sources with regard to the interaction between the IRO and its staff on the ground, various governments and nongovernmental organizations, and the DPs themselves. While it is not yet possible to draw on the results of this investigation here, the analytical value of those sources as well as the outline of future research can be discussed.

\subsection{The Development of the Resettlement through Space and Time}

The example of one single embarkation list may demonstrate the analytical value of those sources. On December 12, 1949, the US-American troopship USAT General S.D. Sturgis left Bremerhaven in Germany toward Chile and Venezuela. The transport was one of the many IRO mass resettlement passages. On board were 598 European refugees and DPs: 421 of them were on their way to be resettled in Chile, 177 had embarked on a voyage to Venezuela. Among the refugees and DPs heading for Venezuela, 71 were male adults, 59 female adults, 38 children aged between 2 and 10 years while 11 children aboard were under the age of 2 . The transport basically consisted of families. ${ }^{16}$ Among the female refugees and

16 Embarkation Nominal Roll for IRO Group Resettlement from Bremerhaven to Chile and Venezuela, 12.12.1949, 3.1.3.2/81665719/ITS Digital Archive, Bad Arolsen. 
DPs most were declared as housewives in the Embarkation Nominal Roll handed over in Bremerhaven, two of them were declared as nurses, and one as a dressmaker. ${ }^{17}$ The declared occupations of the male passengers were very diverse. Only three of them were declared famers, seven were listed as mechanics, five as electricians, four as shoemakers and four as workers, three as carpenters, three as tailors, three as blacksmiths, two as gardeners, two as locksmiths, two as masons, two as turners, two as draftsmen, two as watchmakers, and the rest of the male passengers had six other declared occupations. ${ }^{18}$ All travelers of the passage were either catholic or protestant. Most adults were listed as born in Eastern Europe-Hungary, Yugoslavia, Romania, Poland, the USSR, the CZE, Estonia, and Latvia-except for some accompanying wives who were listed as born in Germany. Many of the children were born in Germany, too. The oldest passenger was the farmer Alexander Ignatenko, aged 53, who travelled with his wife Xenia and their 17-year-old son Konstantin. ${ }^{19}$ This random list of people already indicates that a systematical analysis of the mass resettlement to Venezuela will add a lot of information about who those migrants actually were.

The IRO's resettlement program is mainly narrated through either aggregated statistics or very individual stories. Most often statistical references mirror the whole IRO project's existence; thus, we broadly know how many people were resettled between 1947 and 1951 or 1952 altogether, and by the same token numbers can be broken down to single years. ${ }^{20}$ The systematical analysis of the shipping lists instead promises information about the "real-time" development of the resettlement project across time and space (Bondzio et al. 38). On this basis, the development of the program itself can be appropriately contextualized within the poles of the IRO's mission and the destination countries' political development, and with a focus on those people on the move (Bondzio et al.). Second, those documents will help to answer the key question, who finally migrated

17 It is important to note that some refugees and DPs may either have misrepresented themselves before the IRO according to what they did know about preferred occupations in the destination countries of the resettlement or that maybe even IRO employees passed refugees and DPs off as specialists in certain fields. Nevertheless, the declared occupations on the Embarkment Rolls are the "official" occupations the DPs and refugees were resettled with.

18 Embarkation Nominal Roll for IRO Group Resettlement from Bremerhaven to Chile and Venezuela, 12.12.1949, 3.1.3.2/81665719/ITS Digital Archive, Bad Arolsen.

19 Ibid.

20 Those data are most often cited from either Vernant's book published in 1953 or Holborn's book published in 1956. 
within the project when and whereto, independently from what we know about whom the destination countries wanted to attract. Third, the documents will help to answer the question, how different places of origin and destination were linked through the migration patterns caused by the resettlement scheme. And fourth, by knowing the migrants' personal information from the rolls, we can finally even start to investigate who they were and what happened to them after the IRO lost track through their documentation. Did they remain in Venezuela, for example, or did they migrate again, somewhere else in the Americas or back to Europe? Did they relocate to cities or did they remain in the rural periphery as initially intended by the Venezuelan government? Did they manage to establish new lives? Did they integrate into the societies of the destination countries?

What did those refugees and DPs thus experience, who were these people who got uprooted during World War II or its aftermath and now found themselves celebrating Christmas 1949 together on the General S.D. Sturgis on their way to the newly established military dictatorship in Venezuela, how did they get access to the IRO resettlement program, what had determined their path, and how did their lives go on after arrival?

\subsection{Analyzing the Social "Portal of Globalization"}

Tracing the IRO and ITS records of some of the passengers of the cited Embarkation Roll helps to reconstruct parts of the refugees' and DPs' stories, to interpret the resettlement rather as migration history instead of institutional or diplomatic history. ${ }^{21}$ We cannot reconstruct passengers' stories in every detail here, but exemplarily illustrate how the CM-1 files help to understand how refugees and DPs translated the spatial order(s) and the social space of the resettlement into a solution for their personal "crisis," how they "identified themselves to a bureaucracy" (Afoumado 218), and how they translated the resettlement as a "portal of globalization." Likewise, the documents help to answer a question nobody has raised so far: how did the IRO officers act within the institutional framework of the resettlement program when processing and deciding their cases?

The CM-1 files as well as other IRO records may first serve to empirically prove the assumption that Venezuela (or Latin American countries in general)

21 Not all passengers' CM-1 files are preserved in the ITS archive or they have never been digitalized respectively. Nevertheless, the ITS Digital Archive contains information about several refugees and DPs who were passengers of the General Sturgis and left Bremerhaven on December 12, 1949, toward Venezuela. 
was not the refugees' and DPs' first choice for resettlement. Holborn calls this the "second choice" phenomenon (137). Interviews with DPs from all over the world are one suitable source to answer questions on the DPs own agency to move within the physical and social space of the resettlement program. The documents of the ITS archive however can provide a much larger empirical basis to analyze the agency of the DPs to get access to resettlement in general and to then have the choice to be resettled in their desired destination.

Ernest Chrenovsky, born in Czechoslovakia in 1928, named the United States or Canada as countries of first preference when he was interviewed by an IRO eligibility officer to prove his entitlement to IRO assistance. ${ }^{22}$ His CM-1 file does not contain information about why-contrary to his own hopes-he ended up on the ship to Venezuela on December 12, 1949, but he did. Alois Markech, born in Czechoslovakia in 1929, boarded the same ship after putting on record that he desired to be resettled to Australia. ${ }^{23}$ Their fellow traveler Sandor Varga likewise had claimed Australia as his desired destination. ${ }^{24}$ When Jan Sulyan, born in Czechoslovakia in 1911, applied for IRO assistance to be resettled for political reasons in August 1949 together with his wife and their two children, they stated that they did not yet know where they would like to be resettled to ${ }^{25} \mathrm{He}$ told the IRO office that he had to flee from Czechoslovakia in 1948 for political reasons and the officer classified him as eligible for resettlement. Less than 4 months later the family were passengers on the "General Sturgis" to be resettled in Venezuela. Some corresponding files to the "General Sturgis" embarkation roll however indicate that there were people who desired to be resettled in Venezuela explicitly. For example, Lajos Rigo, born in Hungary in 1920, named Venezuela as his desired destination, when he was registered as a DP in February 1949. ${ }^{26}$ Only 10 months later he was resettled while hundreds of thousands of refugees and DPs - with many of them having applied for assistance earlier than Rigo-were

22 IRO Application for Assistance, Ernest Chrenovsky, 13.5.1949, 3.2.1.1/78997055/ITS Digital Archive, Bad Arolsen.

23 AEF DP Registration Record. Supplementary Record-Face Sheet, Alois Markech, 25.8.1949, 6.3.2.1/84377622/ITS Digital Archive, Bad Arolsen.

24 IRO Application for Assistance, Sandor Varga, 7.7.1949, 3.2.1.1/79799522/ITS Digital Archive, Bad Arolsen.

25 IRO Application for Assistance, Jan Sulyan, 24.8.1949, 3.2.1.1/79878141/ ITS Digital Archive, Bad Arolsen.

26 AEF DP Registration Record, Lajos Rigo, 28.2.1949, 3.1.1.1/68793384/ITS Digital Archive, Bad Arolsen. 
still waiting for their passage. The document does not reveal, however, if he knew of the coup détat that happened in Venezuela 4 months earlier.

Another important question concerns the declared occupations of the refugees and DPs. While Chrenovsky was listed as a presser on the cited Embarkation Nominal Roll from December 1949, for example, his Refugee/Displaced Person Statistical Card, filled out in Fallingbostel, Germany, in June 1949 says that he was a waiter. ${ }^{27}$ It is very unlikely, that he was trained in a new profession within a few months. His fellow traveler Harald Lindner was identified as a photographer and business man on his IRO Statistical Card from April 1948. ${ }^{28}$ The cited Embarkation Nominal Roll of the General Sturgis from December 1949 listed him as a mechanic. It is possible that he was trained as a mechanic during the 18-month period between April 1948 and December 1949. It is however also possible that he was able to act in the social space of resettlement by changing his own biography to be able to pass the "portal of globalization." This is another topic that needs to be analyzed more empirically: the question, if and to what extent the refugees and DPs themselves were able to reinvent their own biographies to increase their chances to be resettled or if the IRO officers did.

The IRO files also reveal a lot of information about how the IRO officers translated the IRO's institutional task on the ground into practices and therewith co-created the social space of resettlement. The documents thereby prove among other things that the officers acted within a wide scope and were able to leave their marks on the social space of resettlement.

Alois Markech, for example, born in Czechoslovakia in 1929, escaped from Ostrava in the Czech Republic in April 1949, crossed the German border (illegally), and applied for IRO assistance in Amberg, Germany, during the same month. He claimed to have risked being sent to a labor camp for having refused to join the Communist Party, wherefore he decided to escape to Germany. The IRO's Child Care Officer in Amberg approved his application on August 25, 1949, noting that Markech was a "normal, young health [sic!] sound boy," who "seems to be honest" and "would like to emigrate to Australia." ${ }^{29}$ The cited ITS file does not tell the story why the 20-year-old Markech ended up being a passenger of the "General Sturgis" leaving Bremerhaven for Venezuela in December 1949. The

27 Refugee/Displaced Person Statistical Card, Ernest Chrenovsky, 29.7.1949, 3.1.1.1/66791406/ITS Digital Archive, Bad Arolsen.

28 IRO Statistical Card, Austria, Harald Lindner, 30.4.1948, 3.1.1.1/68061267/ ITS Digital Archive, Bad Arolsen.

29 AEF DP Registration Record. Supplementary Record-Face Sheet, Alois Markech, 25.8.1949, 6.3.2.1/84377622/ITS Digital Archive, Bad Arolsen. 
example tells us, however, how subjectively decisions in the resettlement process may have been drawn and that this decision-making did not totally or always stay within the IRO's mandate. According to the IRO's constitution, Markech did not really qualify as a DP as he was no victim of displacement during World War II nor a victim of the National Socialists' crimes. ${ }^{30} \mathrm{He}$ translated the social space of resettlement into his chance to escape the Communist Eastern Bloc in 1949 and the IRO officer translated the same social space into an area of action according to his subjective impression of the applicant and his own ideology. ${ }^{31}$

\section{Conclusion}

In this chapter, we argued that the history of the IRO and the resettlement program has basically been written from a Eurocentric perspective and second with a strong focus on postwar politics and the IRO as an organization while the actors who actually translated the idea of resettlement into a practice largely remain in the dark. The resettlement project was based on a vision on how to solve a "refugee crisis" which was perceived in a specific way by the just-emerging United Nations who wrote the IRO's constitution and agreed to finance the resettlement scheme. This does, however, neither explain how certain destination countries translated the program according to their history and politics nor does it shed any light on the actual people involved who translated the program into a personal, social "portal of globalization," namely the IRO's eligibility officers as well as the migrants themselves.

From the perspective of Venezuelan immigration history, the resettlement of European refugees and DPs was one of many episodes, but not even a highlight or a critical juncture (Middell and Naumann). In the Venezuelan historiography of immigration, neither the end of World War II nor the beginning of a new phase of the Cold War is perceived as turning points, but rather changing spatial and political orders in Venezuelan history itself, namely the postindependence and pre-1936 caudillismo with no concept of a nation-state, the post1936 development of a spatial concept of a nation-state and internal agricultural colonialization, and finally the November 1948 coup d'état. It is not wrong when

30 Constitution of the International Refugee Organization 1946.

31 The ITS file also reveals, by the way, that somebody asked the IRO (or maybe the ITS) for help to find Markech in 1949 already. The Child Care Division closed the tracing case in April 1951, confirming that Markech had left Germany toward Venezuela in December 1949. IRO Closed Case Record, Alois Markech, 27.4.1951, 6.3.2.1/84377633/ ITS Digital Archive, Bad Arolsen. 
Holleuffer concludes that Venezuela-like all other Latin American countries"took part in the joint venture of global resettlement work" (Holleuffer 154), but the reason was less the "willingness to accept responsibility within the network of the newly established United Nations" (154) or the result of a "global system of humanitarian-based population transfer" (133), but rather the result of a translation of whatever was considered as the European humanitarian crisis by other actors into their own concept of spatial order and politics.

From analyzing the not yet systematically investigated IRO documentsnamely the embarkment rolls and the care-and-maintenance documents of those refugees and DPs on the embarkment rolls-in the future, we expect empirically validated answers to important open questions about the resettlement program. Who were those refugees and DPs that were resettled in Venezuela between 1947 and 1952, what was their story, why did they end up in Venezuela, and to what extent were they able to influence the processes that brought them there? The CM-1 files thereby also relate the untold story of the IRO officer's actions and agency. As the flip side of the coin, they negotiated resettlement with the refugees and DPs by interpreting the IRO's mission and the refugees' and DPs' histories, narrations, and desires.

To avoid reconstructing the resettlement to Venezuela only as a history of emigration from Europe, but as migration history including the immigration to Venezuela and the further life of the refugees and DPs, we finally also intend to trace their stories in Venezuela. How did they build new lives overseas? How did they integrate into Venezuelan society? How and why did some of them transmigrate? Where did they go, when, and why? How did they cope with the changing and probably unexpected political reality in Venezuela and did they finally even establish a transnational social space of migration (Faist, "Transnational”; Faist, The Transnational)?

The twofold translation of the resettlement as a "portal of globalization" created a specific transnational physical and social space of migration. On the political level, Venezuela translated the program into a part of its own state and nation building project. On the bureaucratic level, the IRO's officers on the ground translated the program into a policy. And from the perspective of migration history, the refugees and DPs translated the program into the chance to start new lives and to even partly reinvent themselves. The sketched goal of our future research is to overcome both the eurocentrism of the history of the IRO and the resettlement project by including Venezuelan immigration history and politics into the picture and overcoming either the eurocentrism of analyzing the refugees' and DPs' stories in Europe or the methodological nationalism to study their stories only in Venezuela. 
The documents of the ITS archive may allow reconstructing the life and migration histories of many of those alleged 17,000 refugees and DPs who were resettled in Venezuela between 1947 and 1952. This is however only the history of an emigration within the social space of the resettlement between Europe and Venezuela. From the perspective of migration history, the question remains open: what happened to the refugees and DPs after the IRO lost their tracks in the so-called European embarkment centers? The IRO's files lose track of the migrants after their embarkation in Europe. The IRO's embarkation lists are the link within the reconstruction of the refugees' and DPs' stories from the perspective of migration history. Some of the ITS's tracing-and-documentation files may serve as sources to answer the question what happened to those refugees and DPs after their voyage to Venezuela. An inevitable step however is to continue the investigation in Venezuela to approximate the question of how people moved and acted within the specific social and physical space that the resettlement program had opened. Tracing the legacy of the refugees and DPs in Venezuela and searching for signs of a transnational social space of migration are therefore the final steps of our intended investigation.

Catalina Banko's recently published article about immigrants from Eastern Europe in Venezuela reveals opportunities to access this part of the story: the question what happened to the refugees and DPs in Venezuela within the spectrum of assimilation, ethnic pluralism, and transnational social spaces (Faist, "Transnational" 214). According to Banko, the different national refugee and DP groups first linked themselves to earlier migrants with similar national backgrounds. They met established communities and thus were often not pioneers. They also soon started organizing themselves in social networks such as associations and cultural and social clubs to help each other, on the one hand, and to preserve cultural heritage and traditions, on the other (Banko 68). The Hungarian refugees and DPs founded the Casa Húngara as a social and cultural club and meeting place for social events. In 1975, the Casa Húngara opened its own kindergarten for the children of the former Hungarian refugees and DPs (69). This fact alone tells a lot about the specific transnational social space of migration. Roughly 25 years after the resettlement, social and cultural ties between the former refugees and DPs seem to have persisted, many of them seem to have stayed in Venezuela and established new lives with children, etc. The Croatian refugees and DPs founded Caritas Croatia already in 1948, later the Asociación Croata de Venezuela, the Comité Croata de Venezuela, and in 1962 social club Hogar Croata that exists until today (71). Also Slovenian, Rumanian, and Bulgarian refugees and DPs founded social clubs and networks, although their number was much smaller (71-73). 
The former Hungarian refugees and DPs finally also organized manifestations and political campaigns during the Hungarian Uprising of 1956 and organized the immigration of about 1,000 Hungarians to Venezuela in 1957 (Banko 70). Thus, the refugees and DPs did not lose sight of their former home countries and countrymen, a sign for the establishment of a transnational social space of migration (Faist, "Transnational"; Faist, The Transnational). Banko concludes that the European refugees and DPs were integrated into the Venezuelan society over the decades; many of them became members of the middle class, but at the same time they preserved their transnational social spaces of resettlement. Her research demonstrates the possibility to continue the story of the postWorld War II refugees and DPs that left Europe for Venezuela between 1947 and 1951/1952 to view it not only as a history of European emigration and international diplomacy but also as a transnational migration history of people on the move.

\section{Primary Sources}

AEF DP Registration Record, Alois Markech, 25.8.1949, 6.3.2.1/84377622//ITS Digital Archive, Bad Arolsen.

AEF DP Registration Record, Lajos Rigo, 28.2.1949, 3.1.1.1/68793384/ITS Digital Archive, Bad Arolsen.

Constitution of the International Refugee Organization, December 15, 1946, cited from Forschungsstelle für Völkerrecht und ausländisches öffentliches Recht der Universität Hamburg (ed.) (1950): Satzung der Internationalen Flüchtlingsorganisation (IRO), Frankfurt am Main: Wolfgang Metzner Verlag, pp. 10-24.

Embarkation Nominal Roll for IRO Group Resettlement from Bremerhaven to Chile and Venezuela, 12.12.1949, 3.1.3.2/81665719/ITS Digital Archive, Bad Arolsen.

IRO (1951): Migration from Europe: A Report of Experience, Geneva: IRO.

IRO Application for Assistance, Charles Abaffy, 23.8.1946, 3.2.1.1/78861775/ ITS Digital Archive, Bad Arolsen.

IRO Application for Assistance, Ernest Chrenovsky, 13.5.1949, 3.2.1.1/78997055/ITS Digital Archive, Bad Arolsen.

IRO Application for Assistance, Jan Sulyan, 24.8.1949, 3.2.1.1/79878141/ITS Digital Archive, Bad Arolsen.

IRO Application for Assistance, Sandor Varga, 24.8.1949, 3.2.1.1/79799522/ITS Digital Archive, Bad Arolsen. 
IRO Closed Case Record, Alois Markech, 27.4.1951, 6.3.2.1/84377633//ITS Digital Archive, Bad Arolsen.

IRO Statistical Card, Austria, Harald Lindner, 30.4.1948, 3.1.1.1/68061267/ITS

Digital Archive, Bad Arolsen.

\section{References}

Afoumado, Diane F. “The 'Care and Maintenance in Germany' Collection: A Reflection of DP Self-Identification and Postwar Emigration."

Freilegungen: Displaced Persons_Leben im Transit: Überlebende zwischen Repatriierung, Rehabilitation und Neuanfang, edited by Rebecca Boehling et al. Wallstein Verlag, 2014, pp. 217-27.

Bachmann-Medick, Doris. "Introduction: The Translational Turn." Translation Studies, vol. 2, no. 1, 2009, pp. 2-16.

Banko, Catalina. "Un refugio en Venezuela: Los inmigrantes de Hungría, Croacia, Eslovenia, Rumania y Bulgaria." Tiempo y Espacio, vol. 65, 2016, pp. 63-75.

Baumann, Claudia, et al. "Portals of Globalization: An Introduction." Comparativ, vol. 27, no. 3-4, 2017, pp. 7-20.

Berglund, Susan, and Humberto Hernández Calimán. Los de Afuera: Un Estudio Analítico del Proceso Migratorio en Venezuela 1936-1985. CEPAM, 1985.

Boeckh, Andreas. "Venezuela: Die schmerzvolle Transformation eines Erdöllandes." Staat, Markt und Rente in der internationalen Politik, edited by Andreas Boeckh and Peter Pawelka. VS Verlag für Sozialwissenschaften, 1997, pp. 285-315.

Bondzio, Sebastian, et al. "People on the Move: Revisiting Events and Narratives of the European Refugee Crisis (1930s-1950s)." Freilegungen: Wege, Orte und Räume der NS-Verfolgung, edited by Henning Borggräfe. Wallstein Verlag, 2016, pp. 36-55.

Buden, Boris, and Stefan Nowotny. "Cultural Translation: An Introduction to the Problem." Translation Studies, vol. 2, no. 2, 2009, pp. 196-208.

Burchardt, Hans-Jürgen. "Die Wirtschaftspolitik des Bolivarianismo: Von der holländischen zur venezolanischen Krankheit?” Venezuela: Die bolivarische Republik, edited by Rafael Sevilla and Andreas Boeckh. Horlemann Verlag, 2005, pp. 173-89.

Caestecker, Frank. “Displaced Persons' (DPs) in Europa seit dem Ende des Zweiten Weltkriegs." Enzyklopädie Migration in Europa: Vom 17. Jahrhundert bis zur Gegenwart, edited by Klaus Bade et al. Schöningh, 2007, pp. 529-35. 
Caestecker, Frank, and Bob Moore. "A Comparative Analysis of Immigration Policies of Liberal States in Western Europe and the Flight from Nazi Germany." Refugees from Nazi Germany and the Liberal European States, edited by Frank Caestecker and Bob Moore. Berghahn Books, 2010, pp. 193-312.

Cohen, Gerald D. "Between Relief and Politics: Refugee Humanitarianism in Post-War Europe." Journal of Contemporary History, vol. 43, no. 3, 2008, pp. 437-50.

Cohen, Gerald D. In War's Wake: Europe's Displaced Persons in the Postwar Order. Oxford University Press, 2012.

Faist, Thomas. "Transnational Social Spaces out of International Migration: Evolution, Significance and Future Prospects." European Journal of Sociology, vol. 39, no. 2, 1998, pp. 213-47.

Faist, Thomas. The Transnational Social Space of Migration. COMCAD, 2006.

Gatrell, Peter. The Making of the Modern Refugee. Oxford University Press, 2013.

Goeken-Haidl, Ulrike. Der Weg zurück: Die Repatriierung sowjetischer Kriegsgefangener und Zwangsarbeiter während und nach dem Zweiten Weltkrieg. Klartext, 2006.

Holborn, Louise. The International Refugee Organization: A Specialized Agency of the United Nation: Its History and Work, 1946-1952. Oxford University Press, 1956.

Holleuffer, Henriette von. "Seeking New Horizons in Latin America: The Resettlement of 100.000 European Displaced Persons between the Gulf of Mexico and Patagonia (1947-1951)." Jahrbuch für Geschichte Lateinamerikas, vol. 39, 2002, pp. 125-61.

Jacobmeyer, Wolfgang. “The 'Displaced Persons' in West Germany, 1945-1951.” The Uprooted: Forced Migration as an International Problem in the Post-War Era, edited by Göran Rystad. Lund University Press, 1990, pp. 271-88.

Marrus, Michael R. The Unwanted: European Refugees in the Twentieth Century. Oxford University Press, 1985.

Middell, Matthias, and Katja Naumann. "Global History and the Spatial Turn: From the Impact of Area Studies to the Study of Critical Junctures of Globalization." Journal of Global History, vol. 5, no. 1, 2010, pp. 149-70.

Pellegrino, Adela. Historia de la Inmigración en Venezuela: Siglos XIX y XX. Academia Nacional de Ciencias Económicas, 1989.

Rass, Christoph, and Frank Wolff. "What Is a Migration Regime?" Migrationsregime: Perspektiven auf ein evasives Konzept der Migrationsforschung, edited by Andreas Pott et al. Springer, forthcoming. 
Salas, Miguel T. Oil, Culture, and Society in Venezuela. Duke University Press, 2009.

Salomon, Kim. Refugees in the Cold War: Towards a New International Refugee Regime in the Early Postwar Era. Lund University Press, 1991.

Ther, Philipp. Die Außenseiter: Flucht, Flüchtlinge und Integration im modernen Europa. Suhrkamp Verlag, 2017.

Veracoechea, Ermila Troconis de. El Proceso de la Inmigración en Venezuela. Academía Nacional de la Historia, 1986.

Vernant, Jacques. The Refugee in the Post-War World. Allen \& Unwin, 1953.

Yundt, Keith W. Latin American States and Political Refugees. Praeger, 1988.

Zeuske, Michael. Kleine Geschichte Venezuelas. C. H. Beck, 2007.

Zeuske, Michael. Von Bolivar zu Chávez: Die Geschichte Venezuelas. Rotpunktverlag, 2008. 



\section{List of Figures and Tables}

\section{Figures}

Fig. 1: Cascade Mountain Range. Source: Wikipedia

Fig. 2: Lawrence Paul Yuxweluptun, "Scorched Earth: Clear-Cut Logging on Native Sovereign Land" (1991). National Gallery of Canada, Ottawa. Source: Duffek/Willard.

Fig. 3: "An Indian Game (Juggling Books)" (1996). Private Collection

Michael Audain. Source: Duffek/Willard.

Fig. 4: "Killer Whale Has a Vision and Comes to Talk to Me about

Proximological Encroachments of Civilizations in the Oceans" (2010). Private Collection. Source: Duffek/Willard.

Fig. 5: "We Are Not a Minority" Mural by El Congreso de Artistas Cósmicos de las Américas de San Diego, East Los Angeles, 1978. Source: Photograph $\odot$ Josef Raab.

Fig. 6: Screenshot from Lone Star (1996).

Fig. 7: The Transnational Remittances Economy. Source: Own elaboration.

Fig. 8: Structure of Foreign Exchange Earnings in El Salvador, 1978 and 2015. Source: IMF Balance of Payments Statistics, various years; BCR; OECD Stat; UNCTAD Stat. 230

Fig. 9: Remittances to El Salvador, 1976-2016. Source: World Development Indicators.

\section{Tables}

Tab. 1: Distribution of National Income and Remittances in El Salvador, 2015. Source: Author's calculation based on DIGESTYC 2015 Encuesta de Hogares de Propósitos Múltiples 2014.

Tab. 2: Refugees and DPs Resettled in Venezuela 1947-1951. Sources: Holborn 442, Vernant 686. 



\title{
INTERAMERICANA
}

\author{
Inter-American Literary History and Culture \\ Historia literaria interamericana y sus contextos culturales \\ Histoire littéraire et culture interaméricaines
}

The new series continues, in substance, series C, "Inter-American Literary Studies" published by Wallstein-Verlag for the Göttingen Center for Advanced Studies in the Internationality of National Literatures (1997-2001).

Publications in the former series:

Frank, Armin Paul, \& Helga Eßmann, eds. The Internationality of National Literatures in Either America: Transfer and Transformation 1. Cases and Problems (1999 - vol. 1:1). Frank, Armin Paul, \& Kurt Mueller-Vollmer. The Internationality of National Literatures in Either America: Transfer and Transformation 2. British America and the United States, 1770s-1850s (2000 - vol. 1:2).

Glasenapp, Jörn. 'Prodigies, anomalies, monsters': Charles Brockden Brown und die Grenzen der Erkenntnis (2000 - vol. 2).

\section{Publications at Peter Lang GmbH:}

Vol. 1 Do the Americas Have a Common Literary History? Edited by Barbara Buchenau and Annette Paatz, in cooperation with Rolf Lohse and Marietta Messmer. With an Introduction by Armin Paul Frank. 2002.

Vol. 2 Barbara Buchenau: Der frühe amerikanische historische Roman im transatlantischen Vergleich. 2002.

Vol. 3 Internationality in American Fiction. Henry James. William Dean Howells. William Faulkner. Toni Morrison. Edited by Armin Paul Frank and Rolf Lohse. 2005.

Vol. 4 Rolf Lohse: Postkoloniale Traditionsbildung. Der frankokanadische Roman zwischen Autonomie und Bezugnahme auf die Literatur Frankreichs und der USA. 2005.

Vol. 5 Armin Paul Frank / Christel-Maria Maas: Transnational Longfellow. A Project of American National Poetry. 2005

Vol. 6 Kurt Mueller-Vollmer: Transatlantic Crossings and Transformations. German-American Cultural Transfer from the 18th to the End of the 19th Century. 2015.

Vol. 7 Marietta Messmer / Armin Paul Frank (eds.): The International Turn in American Studies. 2015.

Vol. 8 Gabriele Pisarz-Ramirez / Markus Heide (eds.): Hemispheric Encounters. The Early United States in a Transnational Perspective. 2016. 
Vol. 9 Jeanette den Toonder / Kim van Dam / Fjære van der Stok (eds.): Native America. Indigenous Self-Representation in Canada, the U.S. and Mexico. 2016.

Vol. 10 Elena Furlanetto: Towards Turkish American Literature. Narratives of Multiculturalism in Post-Imperial Turkey. 2017.

Vol. 11 Earl E. Fitz: Inter-American Literary History. Six Critical Periods. 2017.

Vol. 12 Hans Krabbendam / Derek Rubin (eds.): American Responses to the Holocaust. Transatlantic Perspectives. 2017.

Vol. 13 Gabriele Pisarz-Ramirez / Hannes Warnecke-Berger (eds.): Processes of Spatialization in the Americas. Configurations and Narratives. 2018.

www.peterlang.com 